\title{
QUATERNARY GEOLOGY AND ENVIRONMENTAL \\ GEOCHEMISTRY OF THE FLIN FLON REGION, MANITOBA AND SASKATCHEWAN
}

by

\author{
ISABELLE McMARTIN, M.Sc. \\ A thesis submitted to \\ the Faculty of Graduate Studies and Research \\ in partial fulfilment of \\ the requirements for the degree of
}

Doctor of Philosophy

Department of Earth Sciences

\author{
Carleton University \\ Ottawa, Ontario \\ January 24, 2000 \\ (C) copyright \\ 2000, Isabelle McMartin
}


National Library

of Canada

Acquisitions and Bibliographic Services

395 Wellington Street

Ottawa ON K1A ON4

Canada
Bibliothèque nationale du Canada

Acquisitions et services bibliographiques

395 , rue Wellington

Ottawa ON K1A ON4

Canada
The author has granted a nonexclusive licence allowing the National Library of Canada to reproduce, loan, distribute or sell copies of this thesis in microform, paper or electronic formats.
L'auteur a accordé une licence non exclusive permettant à la Bibliothèque nationale du Canada de reproduire, prêter, distribuer ou vendre des copies de cette thèse sous la forme de microfiche/film, de reproduction sur papier ou sur format électronique.

L'auteur conserve la propriété du droit d'auteur qui protège cette thèse. $\mathrm{Ni}$ la thèse ni des extraits substantiels de celle-ci ne doivent être imprimés ou autrement reproduits sans son autorisation.

\section{Canadä}




\begin{abstract}
The Quaternary geology of the Flin Flon region reflects a complex glacial history at the confluence of two major Sectors of the Laurentide Ice Sheet during the Pleistocene. Surficial glacial deposits exhibit contrasting composition, distribution and morphology related to differences in provenance and glacial sedimentation processes associated with the two ice masses during the last glaciation, and the contrasting nature of the Paleozoic and Shield terrains which underlie the region. The rarity of older glacial sediments beneath surface till demonstrates almost complete glacial erosion during the latest glacial events. Following deglaciation, the area was inundated by Lake Agassiz. Post-glacial lake strandlines record a series of six regressive lake levels formed as the ice front retreated and lower outlets were opened. Glacial rebound has tilted the paleo-water planes to the northeast during the Holocene, with gradients decreasing from the highest to the lowest level, from about $0.34 \mathrm{~m} \mathrm{~km}^{-1}$ to $0.22 \mathrm{~m} \mathrm{~km}^{-1}$. This suggests significant differential uplift in the region following final drainage of Lake Agassiz.
\end{abstract}

The soils of the Flin Flon region are naturally elevated in metals, but concentrations are considerably augmented by atmospheric fallout of smelter-derived particulate emissions. In surface organic soils, the concentrations of smelter elements ( $\mathrm{As}, \mathrm{Cd}, \mathrm{Cu}, \mathrm{Hg}, \mathrm{Pb}, \mathrm{Zn}$ ) decrease with increasing distance from the stack, and regional patterns reflect the historical record of smelter contamination. In the underlying C-horizon till, concentrations show the absence of significant contamination at depth, except at highly contaminated sites $(<4 \mathrm{~km}$ 
from the stack) where metals can be leached from humus into the underlying sediments. The contaminant pathways in the soils vary with the element and distance from the smelter, as indicated by the chemical speciation of the metals in labile and non-labile phases. The maximum radius of detectable contamination varies among the smelter elements, ranging from $70 \mathrm{~km}$ for $\mathrm{Cd}$ to $104 \mathrm{~km}$ for As. Beyond these 'background' distances, the relative proportion of anthropogenic contamination in the surface terrestrial environment is more difficult to estimate, as the geochemical response to bedrock composition becomes more obvious. 


\section{ACKNOWLEDGMENTS}

I am grateful to my field assistants for their enthusiasm and good companionship. The short visits of D. Locas. R. Laframboise, R. DiLabio and B. Shilts in the field were greatly appreciated. P. Henderson (GSC), J. Campbell (SRC), E. Nielsen (MEM) and C. Kaszycki (MEM) significantly contributed to the overall NATMAP Shield Margin Project by providing till compositional and striae data, as well as stimulating discussions. I wish to thank J. Percival (GSC) for providing the time-consuming clay mineralogy analysis, P. Lindsay, G. Hall and J. Vaive (GSC) for supervising the preparation of samples and analytical work, R. Bezys and D. McRitchie (MEM) for field assistance and support near Sturgeon Gill Creek Road in 1995, and T. Lambert (GSC) for kindly providing the digital barometer. I would also like to acknowledge H. Thorleifson (GSC) for enlightening discussions on Lake Agassiz history, and Hudson Bay Mining and Smelting Corporation for their co-operation throughout the smelter project, particularly in providing historical emissions data and archived smelter dusts. I am further grateful to F. Michel (Carleton U.),

my co-supervisor, for offering his suggestions and well appreciated editorial comments, and Bill Shilts (Illinois State Geological Survey), my second supervisor, for his long-distance support and editorial review. The continuing support throughout the writing of R. DiLabio and J.-S. Vincent from Terrain Sciences Division was greatly appreciated. Thanks to R. Lacroix and T. Barry (GSC) for preparing some of the photographs and figures. And finally to my life companion, a special thanks for his patience and uninterrupted faith in the pursuit of my goal (merci ...). 


\section{ORIGINAL RESEARCH CONTRIBUTIONS}

This research has attempted to integrate Quaternary geological and geochemical data sets available for the Flin Flon region. A large portion of the data was collected by the author as part of surficial geology and geochemical mapping studies undertaken under the NATMAP Shield Margin Project in 1991-1995. The interpretations presented here are based on these data, but also incorporate data from other work undertaken under recent surficial geology programs in the area. Till geochemistry and ice flow indicator data were provided by P. Henderson (GSC), J. Campbell (Saskatchewan Research Council), E. Nielsen (Manitoba Energy and Mines) and C. Kaszycki (for the GSC) for certain areas within the Flin Flon region. However, the author is fully responsible for all the interpretations presented in Chapter II. Samples were mainly prepared in the GSC laboratories, although pebbles were sieved and lithologically identified by the author. Some analytical work was done in the GSC laboratories, but most was given under contract to commercial laboratories, following instructions given by the author. Sequential extraction techniques and XRD analysis were done at the GSC, under the supervision of the author and P. Henderson, both of whom conducted the SEM examination of the samples. P. Henderson was the first author for the paper presented in Chapter V, but the author contributed equally to the field procedures, data analysis and interpretation, and significantly to the writing of the manuscript. Lake Agassiz strandlines were measured, mapped and compiled solely by the author. 


\section{TABLE OF CONTENTS}

Acceptance Form

Abstract

ii

Acknowledgments

Original research contribution

$\mathrm{V}$

Table of Contents

List of Tables

List of Figures

CHAPTER I: Introduction

1.1 The study area: location and access

1.2 Previous work

1.3 Objectives 6

1.4 Methods 6

1.5 Plan of thesis

CHAPTER II: Glacial geology

2.1 Introduction

9

2.1.1 Regional setting

2.2.1 Topography and drainage

2.2.2 Climate, soils and vegetation

2.2.3 Bedrock geology

2.2.3.1 Precambrian

18

2.2.3.2 Paleozoic

2.3 Previous research

2.3.1 Early exploration

2.3.2 Surficial mapping

2.4.1 Field methods

2.4.1.1 Ice flow indicator mapping

2.4.1.2 Till sampling

2.4.3 Analytical methods

2.5 Glacial erosional record

2.5.1 Relative chronology

2.5.1.1 Keewatin Sector events

2.5.1.2 Labrador Sector events

2.5.2 Summary of relative chronology 
2.6.1 Till morphology and extent

2.6.1.1 Precambrian terrain $\quad 49$

2.6.1.2 Paleozoic terrain $\quad 50$

2.6.1.3 The Pas Moraine $\quad 50$

2.6.1.4 Reed Lake Interlobate Moraine $\quad 53$

2.6.1.5 Hargrave Moraine $\quad 57$

2.6.2 Characteristics of surface till 58

2.6.2.1 Matrix colour $\quad 58$

$\begin{array}{ll}\text { 2.6.2.1 Texture } & 59\end{array}$

2.6.2.3 Pebble lithology 61

2.6.2.4 Matrix carbonate content $\quad 73$

$\begin{array}{ll}\text { 2.6.2.5 Clay mineralogy } & 78\end{array}$

2.6.2.6 Clay geochemistry $\quad 81$

2.6.2.7 Summary of surface till composition and distribution $\quad 82$

2.6.3 Stratigraphy 86

$\begin{array}{ll}\text { 2.6.3.1 Wanless section } & 87\end{array}$

2.6.3.2 Cormorant Lake section $\quad 89$

2.6.3.3 Millwater section $\quad 91$

2.6.3.4 Mosher Lake section $\quad 91$

2.6.3.5 Glacial stratigraphy from adjacent areas $\quad 94$

2.7 Glacial history

$\begin{array}{ll}\text { 2.7.1 Early glaciations } & 98\end{array}$

2.7.2 Last glaciation $\quad 100$

$\begin{array}{ll}\text { 2.7.3 Deglaciation } & 102\end{array}$

2.8 Discussion 103

2.8.1 Regime of the two ice masses and till depositional processes $\quad 103$

2.8.2 Relation of ice flow events to position of ice divides 105

2.9 Conclusions

CHAPTER III: Paleogeography of Lake Agassiz and regional post-glacial uplift history

3.1 Introduction

3.1.1 Previous research

3.1.2 Physiography and geological setting $\quad 115$

3.2 Location and description of strandlines

3.2.1 Stonewall

$\begin{array}{ll}3.2 .2 \text { The Pas } & 123\end{array}$

$\begin{array}{ll}3.2 .3 \mathrm{Gimli} & 127\end{array}$

$\begin{array}{ll}3.2 .4 \text { Grand Rapids } & 129\end{array}$

$\begin{array}{ll}3.2 .5 \text { Drunken Point } & 130\end{array}$

3.2.6 Ponton 131

3.3 Paleolake levels and tilt history $\quad 135$

3.3.1 Stonewall level 143 
3.3.2 The Pas level

3.3.3 Gimli level

$\begin{array}{ll}\text { 3.3.4 Grand Rapids level } & 146\end{array}$

3.3.5 Drunken Point level 146

$\begin{array}{ll}\text { 3.3.6 Ponton level } & 147\end{array}$

$\begin{array}{ll}\text { 3.3.7 Lower levels } & 148\end{array}$

3.4 Discussion 150

$\begin{array}{ll}\text { 3.4.1 Ice marginal positions and timing of shorelines } & 151\end{array}$

3.5 Summary

3.4.2 History of shoreline deformation 156

CHAPTER IV: Impact of a base metal smelter on the geochemistry of soils

4.1 Introduction

$\begin{array}{ll}4.2 \text { Study area } & 163\end{array}$

$\begin{array}{ll}\text { 4.2.1 Location } & 164\end{array}$

$\begin{array}{ll}4.2 .2 \text { Regional geology } & 165\end{array}$

$\begin{array}{ll}4.2 .3 \text { Climate } & 168\end{array}$

$\begin{array}{ll}4.3 \text { Sources and nature of emissions } & 168\end{array}$

$\begin{array}{ll}4.4 \text { Previous work } & 172\end{array}$

$\begin{array}{ll}\text { 4.5 Methods } & 175\end{array}$

$\begin{array}{ll}\text { 4.5.1 Sampling procedures } & 175\end{array}$

4.5.2 Analytical procedures $\quad 175$

4.6 Results 176

4.6.1 Regional distribution of heavy metals in humus $\quad 176$

4.6.1.1 Determination of background levels 181

4.6.1.2 Distances to background 184

4.6.2 Distribution of trace elements on the forest floor 185

4.6.2.1 Significance of the regional humus database $\quad 190$

4.6.3 Geochemical composition of C-horizon till 192

4.6.4 Vertical distribution of heavy metals in soil profiles 196

4.7 Discussion 199

4.8 Environmental implications 202

$\begin{array}{ll}4.9 \text { Conclusions } & 205\end{array}$

CHAPTER V: The chemical and physical characteristics of heavy metals in humus and till

5.1 Introduction 208

5.2 Regional setting 211

$\begin{array}{ll}5.3 \text { Smelter history and nature of emissions } & 214\end{array}$

$\begin{array}{ll}5.4 \text { Previous work } & 215\end{array}$

$\begin{array}{ll}5.5 \text { Methods } & 218\end{array}$

5.5.1 Field procedures 218

$\begin{array}{ll}\text { 5.5.2 Analytical procedures } & 219\end{array}$ 
5.5.2.1 Sample preparation

$\begin{array}{ll}\text { 5.5.2.2 Standard geochemical analysis } & 219\end{array}$

5.5.2.3 Loss-on-ignition (percent LOI) 220

5.5.2.4 X-ray diffraction (XRD) 220

5.5.2.5 Sequential Extraction Analysis 220

5.5.2.6 Scanning Electron Microscope (SEM) 222

5.6 Results

222

$\begin{array}{ll}\text { 5.6.1 Mineralogy and organic content } & 224 \\ \text { 5.6.2 Geochemical composition } & 224\end{array}$

5.6.3 Chemical speciation 228

5.6.3.1 Zn partitioning 230

5.6.3.2 Hg partitioning 237

5.6.3.3 Ni partitioning 241

5.6.3.4 Partitioning in soil profiles $\quad 242$

5.6.4 SEM examination of particulate matter 246

5.6.4.1 Humus 246

5.6.4.2 Till 252

5.7 Discussion and conclusions 252

5.8 Possible criteria for distinguishing anthropogenic from natural 256 sources of heavy metal enrichment

CHAPTER VI: Summary and Conclusions

6.1 Glacial geology 259

6.2 Lake Agassiz history $\quad 262$

6.3 Impact of smelter fallout on surrounding soils 263

6.4 Conclusions 266

REFERENCES 268 


\section{LIST OF TABLES}

\section{Table Description}

2.1 Qualitative clay-size mineralogy by XRD.

2.2 Correlation of major stratigraphic units with areas adjacent to the Flin Flon region.

3.1 Altitude measurements of Lake Agassiz strandlines.

3.2 Summary of strandline gradients.

4.1 Historical emissions for the Flin Flon smelter.

4.2 Calculated or estimated maximum radius of metal deposition (km) 174 around Flin Flon from previous work.

4.3 Median of element concentrations in humus $(<0.425 \mathrm{~mm})$ as a function of distance from the smelter.

4.4 Median of element concentrations in humus $(<0.425 \mathrm{~mm})$ for samples $>50 \mathrm{~km}$ from the smelter as a function of underlying bedrock.

4.5 Trace metal concentrations in forest litter and bulk humus samples collected in different layers.

4.6 Correlation coefficients $(r)$ between distance from the smelter and 188 percent LOI of organic samples and selected trace elements.

4.7 Relative proportion of smelter metals contained in the $<0.425 \mathrm{~mm}$ to total smelter metal concentrations in complete bulk humus layer.

4.8 Background concentrations in till $(<0.002 \mathrm{~mm})$ as a function of underlying bedrock.

4.9 Smelter impact zones based on percentile of smelter metals in humus. 203

5.1 Distance to background $(\mathrm{km})$ for smelter-related metals in humus. 217

5.2 Sequential extraction scheme. 221

5.3 Distribution of heavy metals in humus and till from transects and 225 background sites.

5.4 Relative distribution of heavy metals in various phases of humus 229 and till.

5.5 Relative proportion of $\mathrm{Zn}, \mathrm{Hg}$ and $\mathrm{Ni}$ in the soluble organic phase of humus and the insoluble portion of humus and till collected from transect and background sites.

5.6 Size and composition of particulate matter enriched in heavy metals in humus from selected sites along the NNW transect and Background Site 2. 


\section{LIST OF FIGURES}

\section{Figure Description}

1.1

1.2

2.1

2.2

2.3

2.4

2.5

2.6

2.7

2.10

2.11

2.12

2.13

2.14

2.15

2.16

2.17

2.18

2.19

2.20

Location map of study area in Manitoba/Saskatchewan and major ice flow features.

Study area showing major physiographic areas, hydrology, moraines, geographic locations, and NTS map sheets.

Photographs showing (a) bedrock dominated terrain of the Precambrian Shield, and (b) typical Paleozoic terrain.

Shaded relief digital elevation model of the study area.

Location map of study area in central Manitoba and

Saskatchewan showing drainage, major moraines,

streamlined forms, and Grass River Basin.

Major bedrock domains and lithologies within the study area.

Main surficial geology features of The Pas area (from

Nielsen and Groom, 1989).

Areas of recent Quaternary geology programs in the Flin

Flon region and major contributors.

Photographs of (a) cross-cutting striated facets east of

Cranberry Portage, and (b) hand dug hole in till near

Sturgeon-Weir River.

Relationship between total carbonate content of the $<0.063$

$\mathrm{mm}$ fraction of till analyzed by AAS versus Leco.

Erosional ice flow indicators measured in the study area

and streamlined landforms derived from surficial geology

mapping.

Early southeastward flow of Keewatin ice.

Main south-southwestward flow of Keewatin ice.

Late southwestward flow of Keewatin ice.

Early westward flow of Labradorean ice.

Main radial flow of Labradorean ice.

Late shifts in the radial flow of Labradorean ice.

Distribution of thin till and bedrock over the Paleozoic cover.

Distribution of thick till and streamlined landforms over the

51

52

Paleozoic cover.

Aerial photograph of The Pas Moraine near Wanless showing flutings and striae directions.

Geology of the Reed Lake Interlobate Moraine showing

major deposits and late glacial ice flow indicators.

Photographs of (a) Reed Lake Interlobate Moraine, and

56

(b) section in subaqueous outwash sediments northeast

of Black Duck Lake. 

till. surface till.

Proportional dot map of silt content $(0.002-0.063 \mathrm{~mm})$ in surface till. surface till.

2.26 Proportional dot map of Paleozoic carbonate clast content in surface till.

2.27 Proportional dot map of Precambrian clast content in surface till.

2.28 Precambrian clast content in till sampled along five transects across the Paleozoic cover.

2.29 Proportional dot map of Paleozoic sandstone clast content in surface till.

2.30 Proportional dot map of total carbonate content (by AAS) in the $<0.063 \mathrm{~mm}$ fraction of surface till.

2.31 Relationship between total carbonate content of the $<0.063$ mm fraction of till analyzed by AAS versus Paleozoic carbonate clast content. Proportional dot maps of (a) calcite, and (b) dolomite in the $<0.063 \mathrm{~mm}$ fraction of surface till. in the clay fraction of surface till. physiographic features and geographic locations.

Moraine, (b) series of gravel beaches across the Sturgeon

Gill Creek road, and (c) major strandlines near Grand Rapids. across the Sturgeon Gill Creek road, (b) section in pebble beach of the Gimli shoreline south of Cormorant,

(c) Drunken Point beach ridge north of Hargrave River,

(d) Ponton strandline north of Minago River, and 
(e) Minago River channel west of Highway 6.

Aerial photographs of the Ponton strandline: (a) east of

Little Limestone Lake, (b) southeast of Minago River,

(c) along the Paleozoic-Precambrian boundary north of

Ponton, and (d) along a low bedrock escarpment north

of Davis Creek.

3.7 Paleogeography of Lake Agassiz reconstructed from strandline elevations and Lake Agassiz isobases:

(a) Stonewall level, (b) The Pas level, (c) Gimli level,

(d) Grand Rapids level, (e) Drunken Point level, and

(f) Ponton levels.

3.8 Plot of strandline elevations from Table 3.1 with reference

to lines of equal post-glacial uplift, and interpreted lake levels.

3.9 Lake Agassiz strandline diagram showing former water

planes and outlets projected onto a vertical plane orthogonal

to the isobases.

3.10 Lake strandline gradients as a function of age in central

Manitoba.

4.1 Location map of study area showing bedrock domains, major glacial landforms, and generalized ice flow directions.

4.2 Location of regional humus and/or till samples, soil profiles, and detailed humus and forest litter sample sites.

Wind rose data for the Flin Flon region.

Regional distribution of (a) $\mathrm{Cu}$ and $\mathrm{Zn}$, and (b) As and $\mathrm{Ni}$ in the $<0.425$ mmfraction of humus.

4.5 Concentrations of major smelter metals in humus as a function of distance from the smelter.

4.6 Fitted curves and correlation coefficients for major smelter metals in forest litter and humus samples.

Regional distribution of (a) $\mathrm{Cu}$ and $\mathrm{Zn}$, and (b) $\mathrm{As}$ and $\mathrm{Ni}$ in the $<0.002 \mathrm{~mm}$ fraction of till.

$4.8 \quad$ Vertical distribution of selected trace and major elements in the $<0.002 \mathrm{~mm}$ of till measured in Sections A, B, and D. Smelter impact zones defined on the basis of total smelter metal concentrations in the $<0.425 \mathrm{~mm}$ fraction of humus. generalized bedrock geology, major glacial landforms and ice flow directions. concentrations of $\mathrm{Zn}, \mathrm{Hg}$ and $\mathrm{Ni}$ in humus and till collected from transect sites. 
(a) total concentration in various phases of humus, (b) percent total $\mathrm{Zn}$ in soluble organic phase and insoluble humus residue and ratio between labile and non-labile components in insoluble humus residue, (c) total concentration in various phases of till.

5.5 Relationship between $\mathrm{Zn}$ concentrations and total organic content: (a) \% Zn in soluble organic phase, (b) total Zn (ppm). 5.6 Partitioning of $\mathrm{Hg}$ in samples collected from transect sites:

(a) total concentration in various phases of humus, (b) percent total $\mathrm{Hg}$ in soluble organic phase and insoluble humus residue and ratio between labile and non-labile components of insoluble humus residue, (c) total concentration in various phases of till.

5.7 Relationship between \% $\mathrm{Hg}$ in soluble organic phase and total organic content.

5.8 Trace element concentrations and partitioning of samples from vertical profiles: Section A (Shield-derived till) and Section B (Paleozoic-derived till).

5.9 SEM secondary electron images showing morphology and composition of spherical particles in humus collected at varying distances from smelter: (a) heavy metal rich particle collected approximately $2 \mathrm{~km} \mathrm{SSW}$ from smelter, and (b) hollow sphere collected $82 \mathrm{~km} \mathrm{NNW}$ of stack.

5.10 SEM secondary electron image of smelter-derived Zn-rich particle observed in humus collected $3 \mathrm{~km} \mathrm{NNW}$ of stack.

5.11 SEM mixed secondary and backscattered image showing metalrich particles and organic material in humus $17 \mathrm{~km}$ SSW of stack. 


\section{CHAPTER I. INTRODUCTION}

The Flin Flon region is one of several areas in which geological surveys designed to provide bedrock and surficial geological maps and respond to societal needs were initiated as part of Canada's National Geoscience Mapping Program (NATMAP). The NATMAP Shield Margin Project in Manitoba and Saskatchewan was carried out in the Flin Flon region in 1991-1995, as a joint effort of the Geological Survey of Canada and the provincial surveys, to stimulate further growth in the region's declining mining industry and obtain geological information required for engineering and environmental management. Surficial geology and geochemical mapping were an important component of this project. This thesis presents a comprehensive analysis of the Quaternary geology and environmental geochemistry of the Flin Flon region, based on surficial geology studies undertaken as part of the Shield Margin Project, and led by the author. The variety of themes covered in the following chapters illustrates the diversity of surficial geology studies in a glaciated terrain, from glacial geology to Lake Agassiz history, and impact of a base metal smelter on the geochemistry of surrounding soils.

\subsection{The study area: location and access}

The Flin Flon region is located at the provincial boundary between Saskatchewan and Manitoba, immediately northwest of Lake Winnipeg (Fig. 1.1), and $650 \mathrm{~km}$ north-northwest of the city of Winnipeg. The study area is traversed by Highway 10 and Highway 6, routes that link Winnipeg to the northern communities, Highway 106 between Flin Flon and Prince 


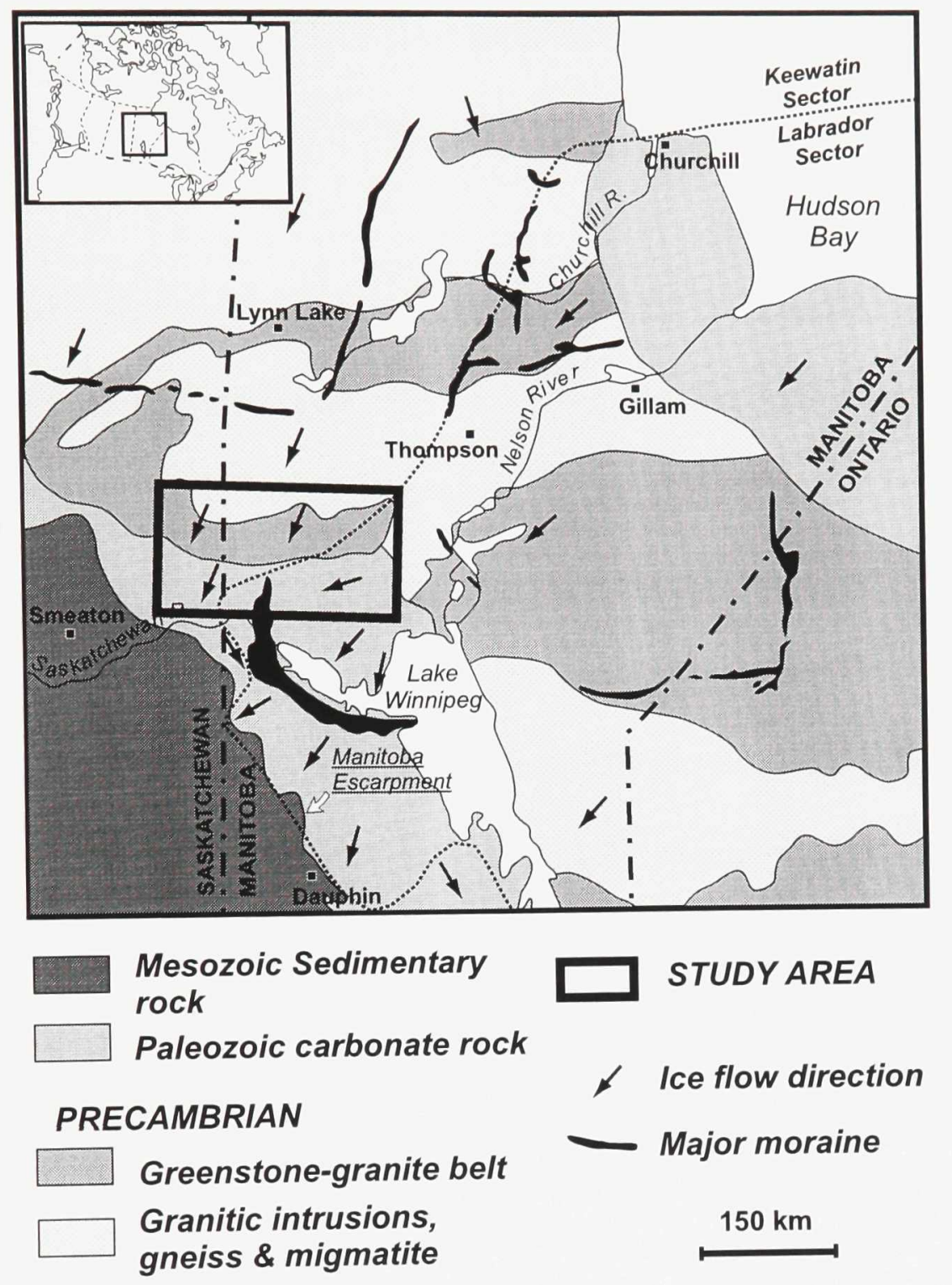

Figure 1.1 Location map of study area in Manitoba/ Saskatchewan and major ice flow features. Dotted line indicates the boundary between Labrador and Keewatin Sector ice of the Laurentide Ice Sheet during the last glaciation (modified from Klassen, 1983 and Prest, 1983). 
Albert in Saskatchewan, highways 39, 135, 167, 287 and 392, and numerous secondary and tertiary forest access roads (Fig. 1.2). The Flin Flon region is also serviced by the Canadian National Railway with railroads leading northeast to Thompson and north to Lynn Lake.

The study area is bounded by latitudes $54^{\circ}$ and $55^{\circ} 15^{\prime} \mathrm{N}$ and longitudes $99^{\circ}$ and $103^{\circ}$ $\mathrm{W}$, and covers approximately $36,000 \mathrm{~km}^{2}$. It is covered by the following 1:250 000 National Topographic Series maps: Cormorant Lake (63K), and parts of Wekusko Lake (63J), Amisk Lake (63L), Pelican Narrows (63M), Kississing Lake (63N), and Nelson House (63O). Communities (1996 population) within the study area include Flin Flon (7119), Snow Lake (1400), Cranberry Portage (723) and Sherridon (95) in Manitoba, and Creighton (1713), Denare Beach (776) and Pelican Narrows (445) in Saskatchewan (Fig. 1.2). The principal activities in the area are mining and smelting, forestry, and tourism. Flin Flon and Snow Lake comprise producing and past-producing gold and base metal mines, and Flin Flon is the site of a base metal smelter that processes ore from local mines.

\subsection{Previous work}

Early exploration in the study area identified a zone of confluence between two major ice masses of the Laurentide Ice Sheet (LIS), and recognized that the whole area had been overridden by a glacier that moved to the south-southwest and that the eastern part was later glaciated from the east (Tyrrell, 1902; McInnes, 1913; Antevs, 1931). More recently, several reports commented on the nature of the surficial sediments in the study area and outlined the history of deglaciation, with particular reference to the zone of confluence between the 


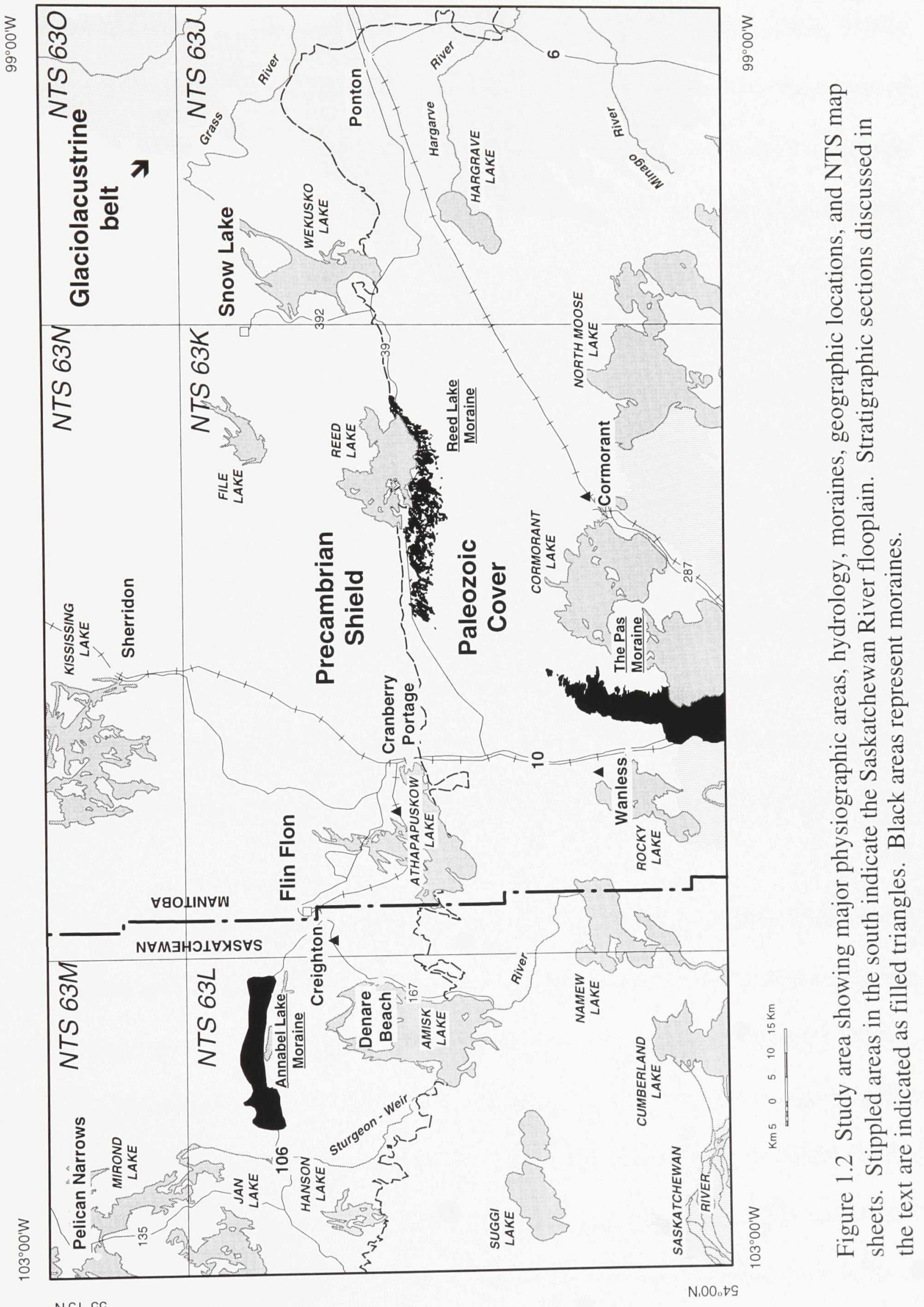


Keewatin and Labrador Sectors of the LIS (Klassen, 1983, 1986; Schreiner, 1984a, 1984b; Nielsen and Groom, 1987; Clarke, 1989; Kaszycki, 1989). The complexity of the pattern of striations reported by these authors indicates that late glacial ice lobes moved in directions differing from earlier regional movements, and that the glacial history is poorly understood.

The post-glacial history of the Flin Flon region, particularly the paleogeography of Lake Agassiz, has been little studied. Although scattered Lake Agassiz shorelines were recognized during early exploration (Tyrrell, 1891; Upham, 1895, Johnston, 1946; Elson, 1967), major errors were made in the correlation of these beaches to those in the south. Shoreline observations along Highway 6 north of Grand Rapids were reported more recently, but conflicting measurements and uplift rates have been suggested (e.g., Ringrose, 1975; Bell, 1978; Klassen, 1983). Teller and Thorleifson (1983) and Thorleifson (1996) presented a schematic Lake Agassiz shoreline diagram based on earlier observations, but there remains a lack of any clear demonstration of the actual gradient of northern Lake Agassiz shorelines.

Previous studies of the impact of the base metal smelter at Flin Flon on the surrounding soils have shown that smelter metal concentrations decrease with increasing distance from the smelter, and with increasing depth from the surface (Hogan and Wotton, 1984; Pip, 1991; Samson, 1986; Zoltai, 1988). However, as these studies were based on data collected at a limited number of sampling sites, and predominantly downwind of the smelter stack, results differ regarding the maximum radius of metal deposition. No data on the physical (e.g., size, shape) and chemical (e.g., mineralogy, residence sites) characteristics of 
heavy metals derived from smelter contamination were available for the Flin Flon region prior to this research.

\subsection{Objectives}

The fundamental objectives of the Shield Margin Project were to provide bedrock and surficial geological maps at the scale of 1:100 000, and develop a digital geoscience database of both existing and new data, including regional compilation maps (Lucas et al., 1999). The specific objectives of the surficial geology component of the project presented in this thesis are to (1) provide a Quaternary geology framework for interpreting transport history of glacial sediments, (2) propose a history of Lake Agassiz configuration, and discuss ice marginal positions, timing and history of shoreline deformation, and (3) examine the extent and nature of heavy metal distribution in soils affected by smelter contamination to distinguish natural from anthropogenic signals.

\subsection{Methods}

Field work was carried out during the summers of 1991 through 1995, with major field seasons of approximately 2 months each year in 1992-93-94. Field data were obtained from hand dug and mechanical excavations, auger holes, and existing exposures. Access was by truck, all-terrain vehicles, or boat. In addition, air support was required in non-accessible areas, mainly by helicopter over the Paleozoic terrain and floatplane to lakes on the Precambrian Shield. Activities consisted of surficial geology mapping, till and humus sampling, and altitude measurement of shorelines. Surficial geology was interpreted using 
aerial photography at a scale of 1:60 000, and maps were digitally compiled at 1:100 000 scale. Interpreted lake levels from mapped shorelines were traced on 1:50 000 topographic maps, and digitally compiled at that scale. Mineral soil samples were analysed for lithological, geochemical and mineralogical composition, and texture and colour determinations. Organic soil samples were analysed for geochemical and mineralogical composition, and organic content. A selection of till and humus samples from transects and soil profiles were subjected to detailed physical and chemical partitioning studies. Results were compiled in a digital database and incorporated in a geographical information system (GIS).

\subsection{Plan of thesis}

Two major themes related to the surficial geology of the Flin Flon region have been developed in the thesis. The first part is the Quaternary Geology, and includes Chapter II, Glacial geology, from which an extended version will be prepared and submitted for publication as a Geological Survey of Canada Bulletin, and Chapter III, Paleogeography of Lake Agassiz and regional post-glacial uplift history, a paper already accepted by the Journal of Paleolimnology. The second part is Environmental Geochemistry, and includes Chapter IV, Impact of a base metal smelter on the geochemistry of soils, a paper published in the Canadian Journal of Earth Sciences, and Chapter V, The chemical and physical characteristics of heavy metals in humus and till in the vicinity of the base metal smelter, a paper co-authored with P.J. Henderson and others and published in Environmental Geology. Since the thesis is presented as separate papers, the discussion is mostly developed within 
each chapter. However, a summary of the main aspects discussed in each chapter, together with conclusions outlining the major interpretations, are provided in the final part of the dissertation. 


\section{CHAPTER II. GLACIAL GEOLOGY}

(an extended version of this chapter to be submitted as a GSC Bulletin)

\subsection{Introduction}

One of the objectives of the Shield Margin Project is to provide a Quaternary geology framework for interpreting transport history of sediments and understanding glacial dispersal of mineral deposit indicators in a region that comprises one of the most productive base metal greenstone belts in Canada (mainly $\mathrm{Cu}, \mathrm{Zn}$ ). Increased recognition of the usefulness of till sampling as an exploration tool in glaciated terrain (e.g., Shilts, 1984; Coker and DiLabio, 1989; Kujansuu and Saarnisto, 1990; McClenaghan et al., 1997), and striation mapping for reconstructing ice flow events (e.g., Veillette, 1986; Kleman, 1990), necessitated the acquisition of a more thorough knowledge of the glacial record. Glacial geology studies in the Flin Flon area, therefore, included surficial geology mapping, systematic ice flow indicator mapping, and regional till sampling.

Till, which is a first-cycle sediment directly deposited by glacier ice, is composed of freshly crushed bedrock blended with reworked older sediments, and transported for a few metres to many kilometres along a preferred orientation related to the ice flow history (Shilts, 1993). Processes of glacial erosion, transport and deposition affect the provenance and composition of glacial deposits, and basically reflect glacial history and ice flow dynamics (Klassen, 1997). The research presented in this chapter deals with the ice flow record, and the distribution, sedimentology, composition and stratigraphy of glacial sediments, 
particularly till, which were used for interpreting the glacial history and understanding the source of the sediments.

\subsubsection{Regional setting}

The Flin Flon region is located along two major contrasting geological features that influenced both ice flow history and till composition (Fig. 1.1): 1) the contact zone of two competing ice masses originating from two major centres of outflow within the Laurentide Ice Sheet and 2) the Paleozoic/Precambrian Shield contact.

As early as the last century, on the basis of striae measurements and intuitive insight, Tyrrell $(1902,1914)$ proposed that the Laurentide Ice Sheet had three centres of growth: one in Keewatin, one in Labrador-Québec, and one in the District of Patricia in northern Ontario. Based on inferred climatic and topographic parameters, Flint (1943) later suggested a different theory, in which all ice flowed radially from a single dome centred over Hudson Bay. More recently, the work of Shilts (1980) and Shilts et al. (1979) on the lithology of erratics in the Keewatin and adjacent Hudson Bay regions resulted in the concept of a multidome configuration with long lasting dispersal centres in Keewatin and Labrador-Nouveau Québec. On the other hand, re-interpretation of data collected by Tyrrell (1914) in northern Ontario forced rejection of the "Patrician" dome (Thorleifson and Kristjansson, 1993). Dyke and Prest (1987a) and Thorleifson et al. (1993) also favored glacial inception in Québec and Keewatin but suggested migration of the ice domes during ice-sheet expansion, and, to explain sustained Late Wisconsinan southwestward ice flow across the entire Hudson Bay 
Lowlands (HBL), the presence of a saddle connecting the two domes during the last glacial maximum (LGM) at $18 \mathrm{ka} \mathrm{BP.} \mathrm{In} \mathrm{addition} \mathrm{to} \mathrm{Keewatin} \mathrm{and} \mathrm{Québec} \mathrm{domes,} \mathrm{a} \mathrm{dispersal}$ centre in the southwestern part of Hudson Bay ("Hudson dome") was proposed at $10 \mathrm{ka} \mathrm{BP}$ to satisfy a requirement for symmetry of ice domes and a source for the Cochrane ice advances (Dyke et al., 1982; Dyke and Prest, 1987b).

The study area straddles the Paleozoic/Precambrian Shield boundary where contrasting glacier bed conditions were present on either side of the Shield edge. Some recent models of the Laurentide Ice Sheet have assumed that Precambrian lithologies provided a hard, largely impermeable substrate where meltwater drained at the base of the ice through eskers, whereas Paleozoic rocks and their derived thick carbonate tills provided a poorly permeable glacier bed, where high water contents trapped in the sediments caused a decrease in shear strength and deformation of the soft materials, and induced glacial surges (e.g., Boulton and Jones, 1979; Clayton et al., 1985; Fisher et al., 1985). In addition, Hicock et al. (1989) proposed that thick silty calcareous till covering parts of the Shield in northern Ontario acted as a low resistance substratum for ice streams by providing deformable subglacial sediments and/or supporting high subglacial water pressures. Likewise, in the Flin Flon region, the boundary between hard and soft substrata may not coincide with the Shield margin, as sandy, permeable tills have been glacially dispersed over Paleozoic bedrock by Keewatin ice, and Labradorean ice has carried calcareous, poorly permeable sediments from the Hudson Bay Lowlands over the Shield. Ice flow models inferred from glacial dispersal data and directional landforms and microforms must therefore incorporate variations in 
glacier bed characteristics, including the distribution and thickness of low-resistance soft beds.

\subsection{Study area}

The northern half of the project area is underlain by Precambrian rocks of the Churchill structural province of the Canadian Shield, which are overlain in the southern half by Paleozoic carbonate rocks of the Williston Basin. As a consequence, marked differences in physiography and drift thickness are found on either side of the Shield margin.

\subsubsection{Topography and drainage}

The Flin Flon region includes three main physiographic areas: 1) the Precambrian Shield, 2) the Paleozoic cover, and 3) a belt of thick glaciolacustrine sediments (Fig. 1.2). The Precambrian Shield in the north is characterized by an undulating to low knobby relief $(<50 \mathrm{~m})$ dominated by bedrock and covered by thin drift $(<3 \mathrm{~m})$ (Fig. 2.1a). The elevation of much of this area is above $300 \mathrm{~m}$ a.s.1., approaching $410 \mathrm{~m}$ in the northwest (Fig. 2.2). The Annabel Lake Moraine (Henderson, 1995a), composed of a thick sequence of sand and gravel (>20 m), forms a positive relief feature north of Annabel Lake (Fig. 1.2), reaching an elevation of $365 \mathrm{~m}$ a.s.1. (Fig. 2.2).

Over Paleozoic rocks in the south, relief is flat to gently undulating, forming a southward sloping plain interrupted by low, thinly drift covered, dolostone mesas, with intervening lowlands filled with fine grained till and glaciolacustrine sediments (Fig. 2.1b). 

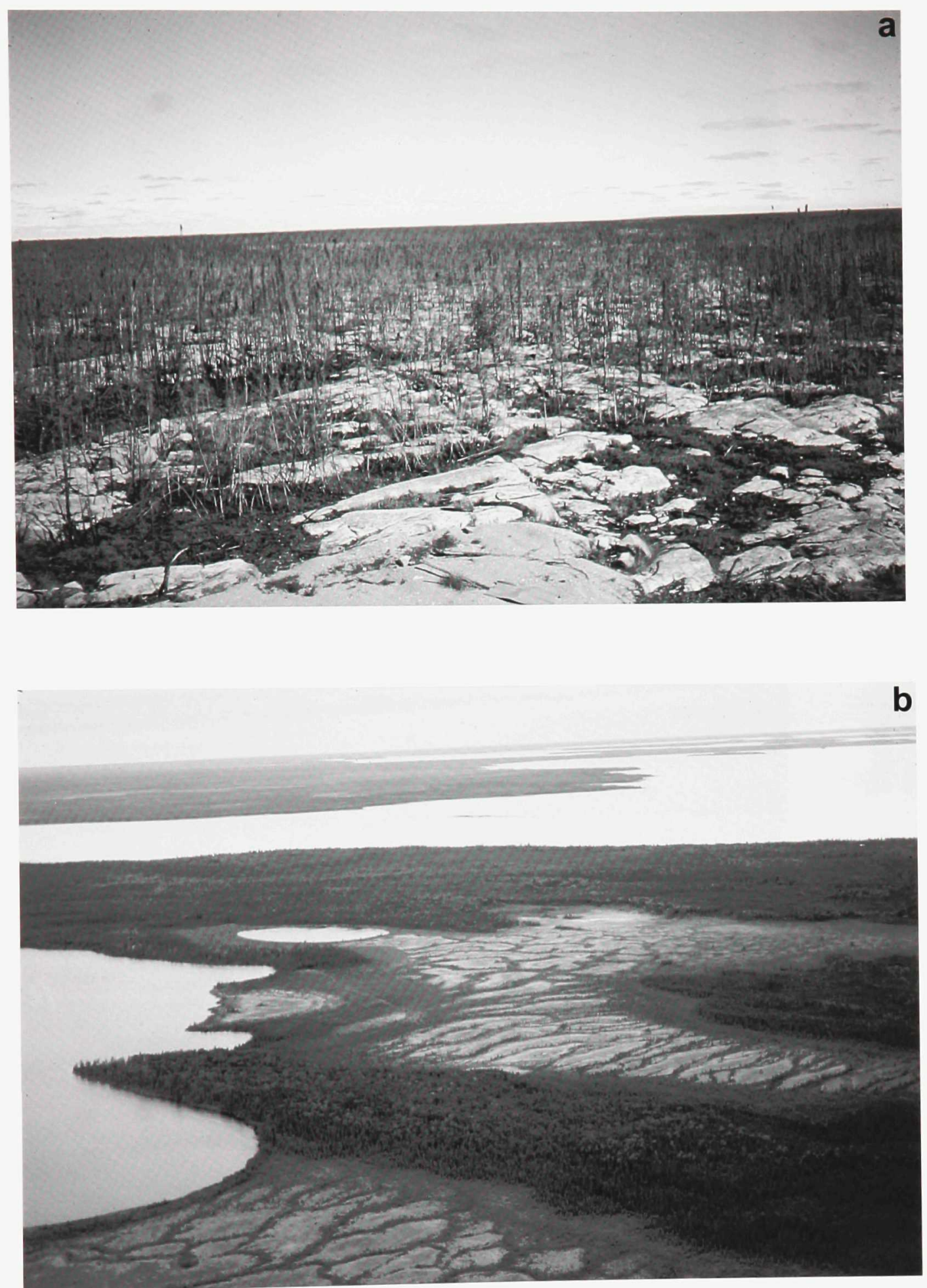

Figure 2.1. Photographs showing (a) bedrock dominated terrain of the Precambrian Shield, and (b) typical Paleozoic terrain where streamlined till is interspersed by peatlands. 


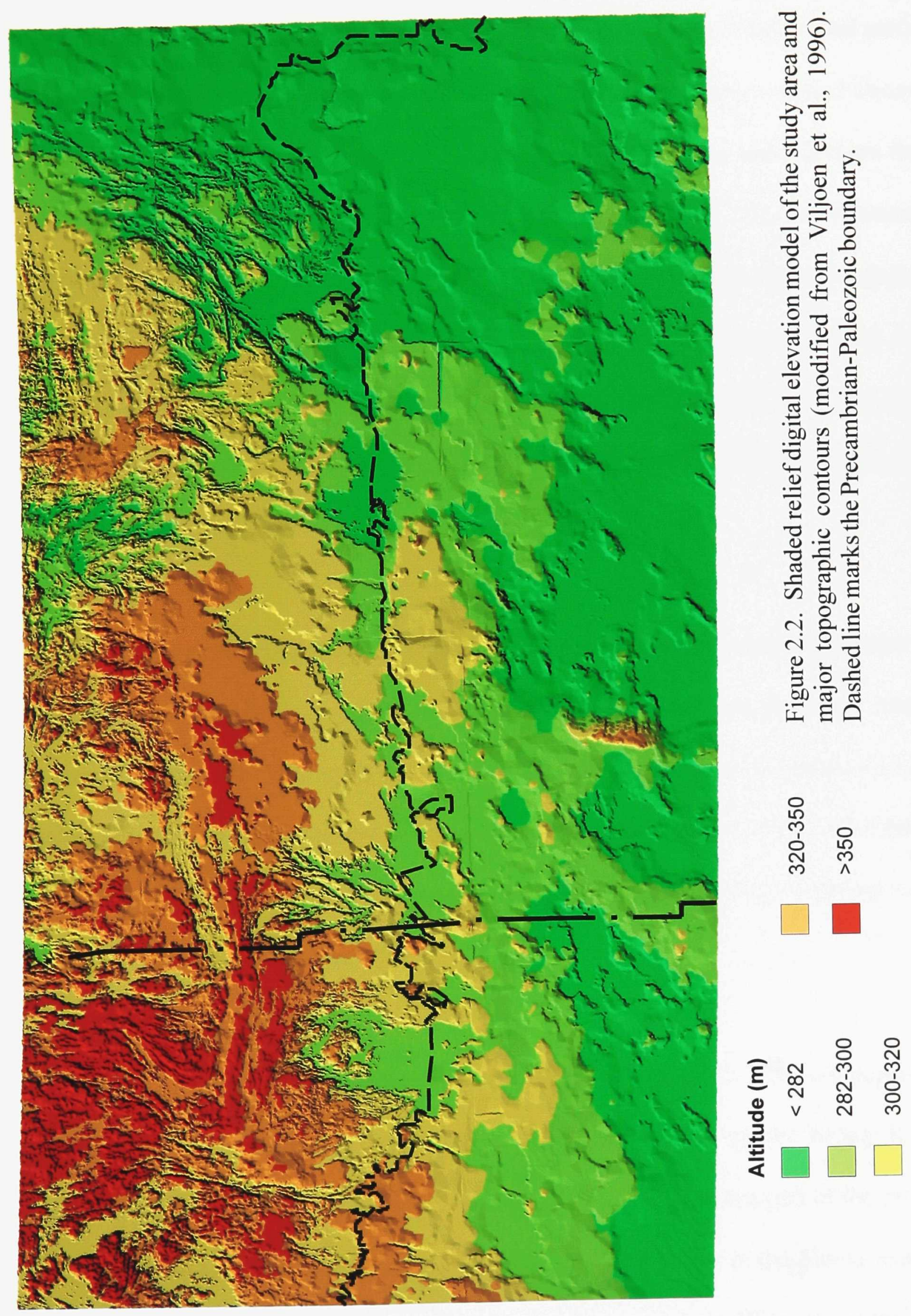


Drift is more continuous and thicker in places $(>5 \mathrm{~m})$, and elevation of the ground surface is generally below $300 \mathrm{~m}$ a.s.l. (Fig. 2.2). A prominent topographic feature on the Paleozoic cover is the arcuate, The Pas Moraine (Antevs, 1931), that extends for about $300 \mathrm{~km}$ from its northern tip in the study area to Long Point in Lake Winnipeg (Fig. 2.3). The moraine is composed of up to $80 \mathrm{~m}$ of till (Pedersen, 1973), and the top of the ridge reaches as high as $337 \mathrm{~m}$ a.s.l. in the study area, approximately $50 \mathrm{~m}$ above the surrounding terrain (Fig. 2.2). Thick alluvial sediments deposited in the Saskatchewan River floodplain are found in the south, forming extensive wetlands that mask the underlying bedrock/glacial topography (Fig. 1.2).

A thick sequence (up to $44 \mathrm{~m}$ ) of fine grained glaciolacustrine sediments covers the eastern part of the study area where vast regions of open water and peatlands form a monotonous landscape. The fine-textured sediments were deposited in the centre of a Lake Agassiz depositional basin referred to as the Grass River Basin (Elson, 1967). The paleobasin consists of a bedrock-controlled depression (Viljoen et al., 1996), extending north towards the Thompson area (Fig. 2.3).

The entire study area lies within the Hudson Bay drainage basin. The eastern portion of the area, dominated by the glaciolacustrine belt, drains eastward into the Nelson River, mostly through the Grass and Hargrave Rivers (Fig. 1.2). The southern part of the project area, including most of the Paleozoic terrain and large lake basins at the Shield margin, drains southward into the Saskatchewan River which flows into Lake Winnipeg to the east. 


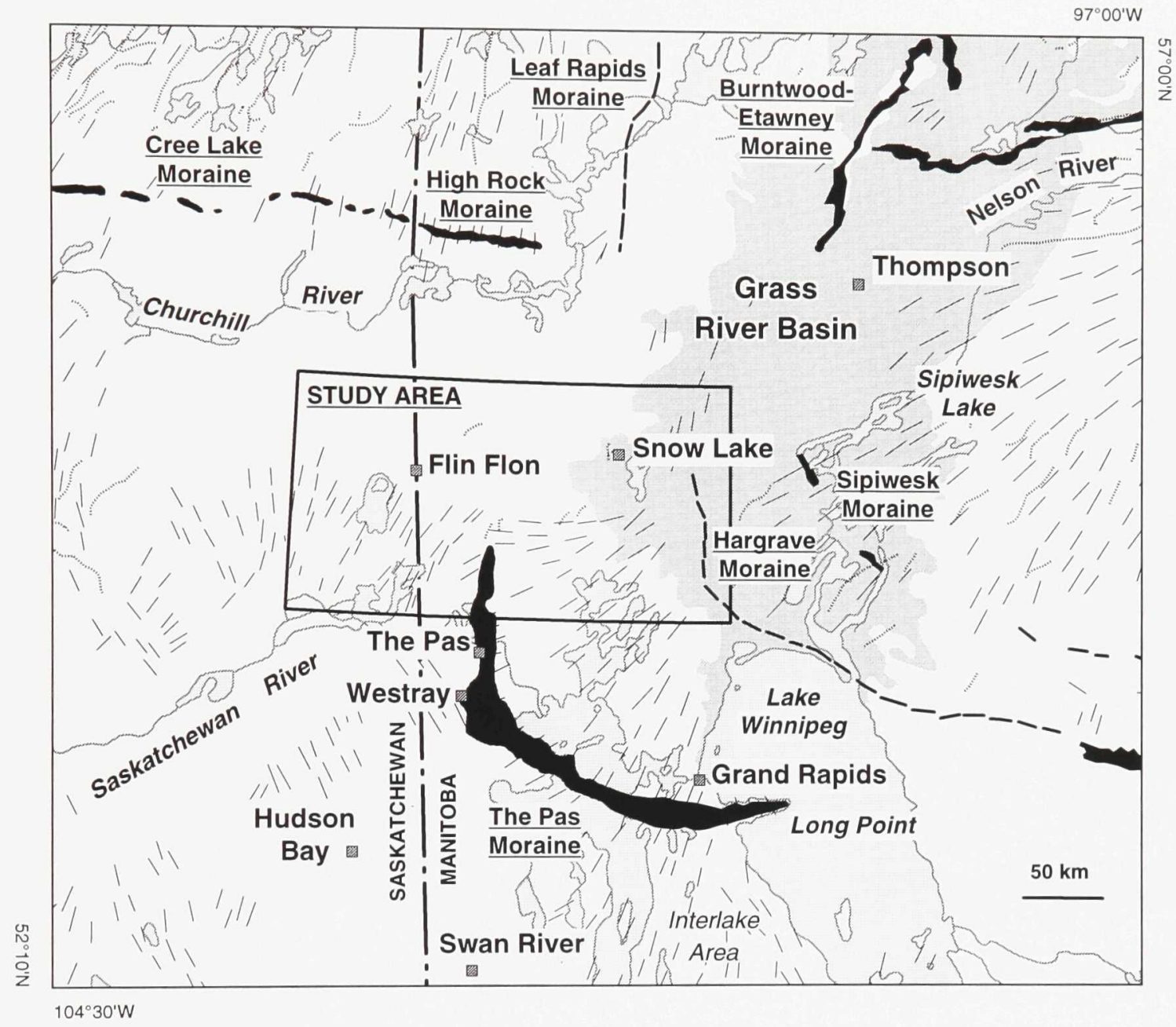

Figure 2.3 Location map of study area in central Manitoba and Saskatchewan showing drainage, major moraines, streamlined forms (flutings and eskers), and Grass River Basin (modified from Klassen, 1983 and Fulton, 1995). 
Lake Winnipeg in turn empties north into the Nelson River. The northern extremity of the study area, mainly the areas around Kississing Lake, drains north in the Churchill River which flows directly into Hudson Bay.

2.2.2 Climate, soils and vegetation

The climate is continental, characterized by cold winters (January mean temperature: $-21.1^{\circ} \mathrm{C}$ ), and relatively warm summers (July mean temp.: $18.3^{\circ} \mathrm{C}$ ) (Environment Canada, 1993). With the exception of the southwestern extremity, the study area is located within the discontinuous permafrost zone (Fisheries and Environment Canada, 1978). Permafrost is present mainly in peat plateaus and isolated palsa, or may occur occasionally in fine grained glaciolacustrine sediments mantled with peat.

Brunisols and luvisols are the most common soils developed on glacial deposits within the study area. Over Precambrian terrain, brunisolic soils occur on well drained surficial deposits, mainly non-calcareous sandy tills (Acton and Padbury, 1984). Luvisolic soils are widespread over the Paleozoic and occur mainly in well-drained calcareous sediments in which the clay fraction exceeds 5\% (Acton and Padbury, 1984).

The area is forested by a mixed coniferous deciduous boreal community composed of jack pine (Pinus banksiana), black spruce (Picea mariana), white spruce (Picea glauca), balsam fir (Abies balsamea), trembling aspen (Populus tremuloides), and paper birch (Betula papyrifera). In organic terrains and areas of human disturbance, the trees are more dispersed, 
particularly in fen bogs or in the vicinity of the smelter.

\subsubsection{Bedrock geology}

\subsubsection{Precambrian}

Bedrock lithologies within the Precambrian Shield have been grouped into three major lithotectonic domains (Fig. 2.4): the Flin Flon Belt and the Kisseynew Domain of Proterozoic age, and the Archean Churchill-Superior Boundary Zone (CSBZ)(e.g., Bailes and Syme, 1989; Zwanzig and Schledewitz, 1992; Reilly et al., 1995; Ashton et al., 1999; Lucas et al., 1999).

\section{$\underline{\text { Flin Flon Belt }}$}

The Flin Flon Belt covers approximately $60 \%$ of the Precambrian terrain in the study area and has a transitional boundary to the north and east into high-grade gneisses of the Kisseynew Domain. The Flin Flon Belt comprises a greenstone belt of supercrustal rocks and associated intrusives, in tectonic contact with the Hanson Lake Block to the west; it represents a relatively low metamorphic grade component of the Trans-Hudson Orogen. The greenstone belt consists of subaqueous mafic flow rocks, felsic flow rocks and porphyries, subaerial volcaniclastic rocks, sedimentary rocks, and syn- to post-volcanic dykes and sills. These rocks have been intruded by a diverse suite of intrusive rocks during various phases of deformation. The Hanson Lake Block comprises a mixed assemblage of volcanic, volcaniclastic, and sedimentary rocks, intruded by rocks of a wide compositional range, and thrust over a mylonite zone termed the Pelican Window. Numerous base and precious metal 


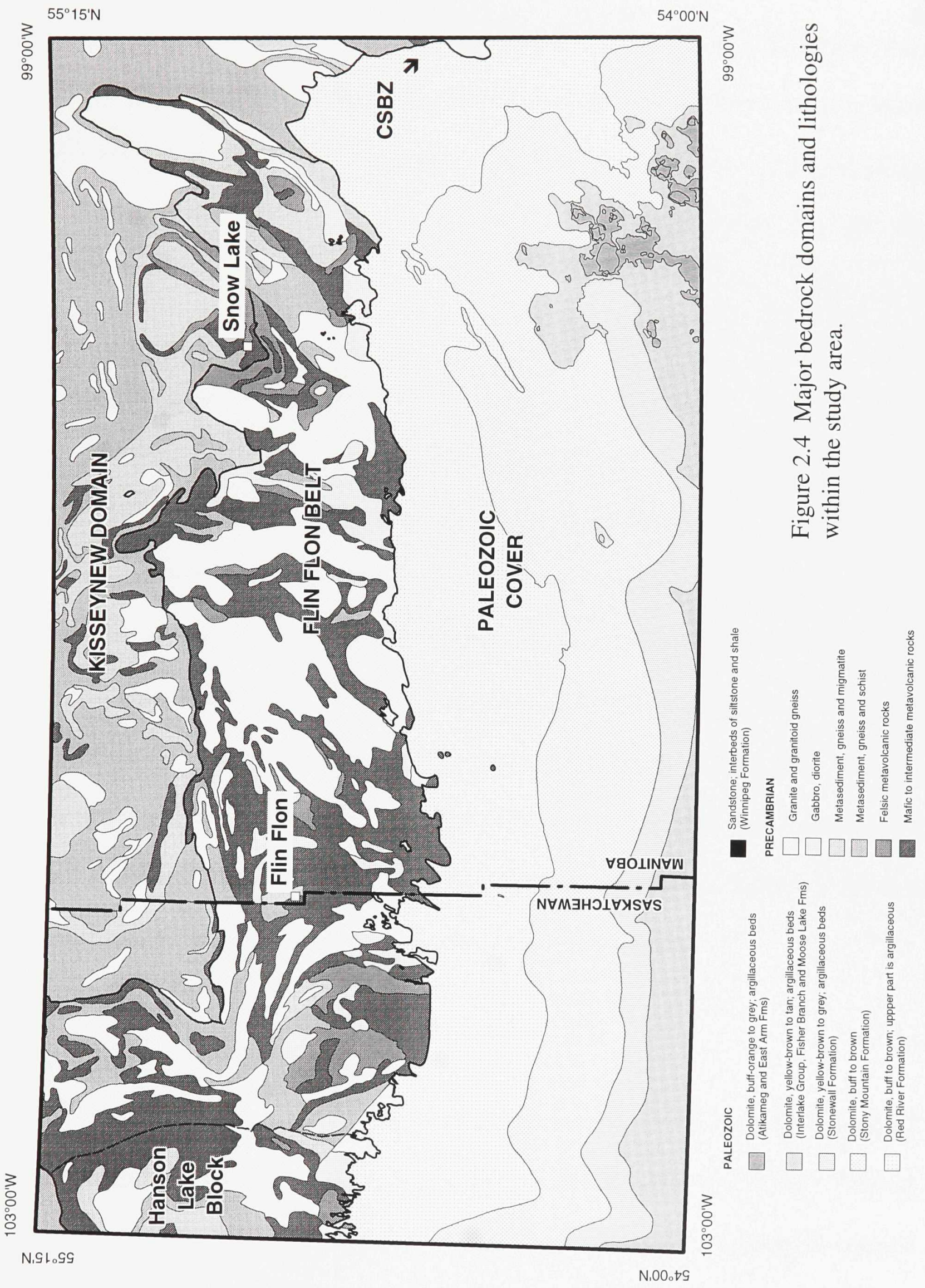


occurrences have been reported in the Flin Flon Belt. In the Flin Flon and Snow Lake areas, producing and past-producing mines have been developed in large $\mathrm{Zn}$ and $\mathrm{Cu}$ ore bodies ( $\pm \mathrm{Au}, \mathrm{Cd}, \mathrm{Pb}, \mathrm{Ag}$ ), classified as volcanogenic massive sulphide (VMS) deposits associated with felsic volcanic rocks, and in minor deposits of porphyry-style $\mathrm{Cu}$ (Mo-Au) mineralization.

\section{$\underline{\text { Kisseynew Domain }}$}

The Kisseynew Domain covers approximately $40 \%$ of the Shield terrain in the study area and is flanked to the south and west by the Flin Flon Belt, and to the east by the Churchill-Superior Boundary Zone. The Kisseynew Domain comprises east-trending supracrustal and intrusive rocks, part of the South Flank of the gneiss belt which extends to the north. The South Flank consists of fine grained amphibolite and associated rocks, graphite-bearing gneisses, migmatites and minor amphibolite, quartz-rich metasedimentary gneiss, and metavolcanics. Massive sulphide $(\mathrm{Cu}-\mathrm{Zn} \pm \mathrm{Au})$ mineralization on the south flank of the Kisseynew Domain is hosted primarily in the Sherridon Suite at Sherridon, which is the site of one of only two mines to have operated in the gneiss belt.

\section{Churchill-Superior Boundary Zone}

The Churchill-Superior Boundary Zone represents the western edge of the Superior Province Craton. CSBZ rocks outcrop in a small area, immediately east of Ponton. They are part of the Thompson Belt, extending northeast towards the town of Thompson and comprise Archean gneisses in fault contact with the Kisseynew gneisses of the Churchill Province. 
Major nickel deposits occur in the Thompson Nickel Belt, 100 to $140 \mathrm{~km}$ northeast of the area.

\subsubsection{Paleozoic}

Unmetamorphosed Paleozoic rocks unconformably overlie Archean and Proterozoic rocks in the southern half of the area (Fig. 2.4), gently dipping southward and attaining a maximum thickness of $125 \mathrm{~m}$ at the southern edge of the study area (Leclair et al., 1997). The Paleozoic cover consists of Ordovician and Silurian rocks (Bezys, 1991, 1992; Haidl, 1992; Kreis and Haidl, 1994). Base metal mineralization occur below this Phanerozoic cover within the continuation of the Hanson Lake Block, the Flin Flon Belt (Spruce Point $\mathrm{Cu}-\mathrm{Zn}$ Mine), the Namew Gneiss Complex (Namew Lake Ni-Cu Mine), and the Churchill-Superior Boundary Zone.

\section{Winnipeg Formation}

The Winnipeg Fm of Ordovician age forms the base of the Paleozoic sequence, and unconformably overlies weathered Precambrian rocks. It comprises a basal grey to greyish red, friable medium to coarse grained quartz sandstone, and an upper unit dominated by argillaceous siltstone/sandstone. Small outcrops of basal sandstone beds are found near the Shield margin, mainly south of Hanson Lake, east of Amisk Lake (Byers and Dahlstrom, 1954), and south of Reed Lake. Outcrops have also been reported in the Athapapuskow Lake and Cranberry Portage areas (Kupsch, 1952). 


\section{$\underline{\text { Red River Formation }}$}

The Ordovician Red River Fm conformably overlies the Winnipeg Fm. It commonly forms prominent cliffs at the Shield margin along the south shores of Hanson Lake, Amisk Lake, Athapapuskow Lake, and Wekusko Lake. The Red River Fm comprises two parts: a lower buff to brown, mottled dolomitic mudstone, displaying a well-developed joint system with deep crevasses, and an upper argillaceous dolomite, interbedded with dolomitic shales. Most of the known Paleozoic outliers on the Shield in the study area are composed of this Formation (Kupsch, 1952).

\section{Stony Mountain Formation}

The Stony Mountain Fm of Ordovician age consists of thick-bedded, yellow-brown, mottled to nodular, dolomitic mudstone grading into thinly-bedded dolomitic mudstone. An escarpment is commonly found at the lower contact where resistant Stony Mountain strata overlie the recessive argillaceous dolomites of the Upper Red River Fm.

\section{$\underline{\text { Stonewall Formation }}$}

The Stonewall Fm is Ordovician to Silurian in age and is composed of yellow-brown to grey dolomitic mudstone/wackestone with minor interbeds of red argillaceous dolomite/dolomitic shales. The contact with the underlying Formation is gradational.

\section{$\underline{\text { Interlake Group and other Silurian Formations }}$}

The Interlake Group of Silurian age consists of light brown to tan to buff orange, 
massive to laminated, dolomitic mudstone/wackestone, interbedded with argillaceous/arenaceous dolomite, shale and sandstone. The Fisher Branch, Moose Lake, Atikameg and East Arm Fms are composed primarily of dolostone and red argillaceous dolomitic beds; these Silurian Fms outcrop in the southeastern part of the Paleozoic cover.

\subsection{Previous research}

\subsubsection{Early exploration}

The early observations of Pleistocene features by Tyrrell $(1892,1902)$ made reference to striae directions and roughly outlined the limits of two glaciations in the area, named Keewatin and Patrician. Similar to Tyrrell (1902), McInnes (1913) recognized that the whole area had been overridden by a glacier that moved to the south-southwest (Keewatin), and that the eastern part was later glaciated from the east (Patrician). Tyrrell (1914) suggested later that three centres of ice dispersal had been located in a region to the southeast (Patrician), the east (Labradorean), and the northwest (Keewatin) of the Hudson Bay Basin, and that each centre dominated a particular period of glaciation.

Antevs (1931) made additional striation measurements and examined laminated sediments from the last stages of Lake Agassiz in the Grass River Basin, which led to regional correlations of late glacial recession events in Manitoba. He differentiated Labradorean ice flows (westward) from Patrician ice flows (northwestward) in east-central Manitoba, but suggested that the centre of outflow in the District of Patricia in north-central Ontario had ceased to function prior to deglaciation, becoming part of the "Labrador ice 
sheet". In addition, he recorded two "morainic ridges" in the study area that were oriented northeast-southwest, between the northern tip of The Pas Moraine and Reed Lake.

\subsubsection{Surficial mapping}

Several reports comment on the nature of the surficial sediments and the history of deglaciation in the area, with particular reference to the zone of confluence between the two ice masses identified by the early workers. Preliminary reconnaissance work was made by Craig (1966) to the south in The Pas area, and by Klassen (1967) to the southeast in the Grand Rapids area. Both authors noted that The Pas Moraine was fluted on top, at right angle to the moraine front, which Klassen (1967) interpreted as glacial overriding during a late readvance. Bell (1978) proposed a sequence of glacial and deglacial events in the Wekusko Lake area, based on observations of surficial sediments and striae he collected while mapping the bedrock. Similar to McInnes (1913), he suggested that the area east of Wekusko lake had been later glaciated by a glacier flowing to the southwest and westsouthwest. Klassen (1980a, 1980b) compiled the surficial geology of the Wekusko Lake (NTS 63J) and Nelson House (NTS 63O) areas at a regional scale (1:250 000), and later outlined the history of deglaciation as part of a reconnaissance study of north-central Manitoba (Klassen, 1983, 1986). On the basis of differences in texture and composition of tills and the orientation of ice flow features, Klassen (1986) associated surface till characteristics to two major ice flows, a till of eastern provenance ("Hudson", Labrador Sector), and a till of northern provenance (Keewatin Sector). 
Nielsen and Groom $(1987,1989)$ documented ice flow events and till provenance on either side of The Pas Moraine, and discussed the Quaternary geology history of The Pas-Flin Flon area. They recognized and named several till sheets differentiated by composition and distribution: 1) the Wanless till, deposited by southerly Keewatin ice flows and found west of The Pas Moraine, 2) the Clearwater till, found within and east of the moraine, and 3) the Arran till, named and recognized earlier by Klassen (1979) south of The Pas, and deposited by a readvance of "Hudsonian" ice (Labradorean) forming the flutes on top of The Pas Moraine. These authors also tentatively named the Reed Lake Interlobate Moraine, a series of glaciofluvial (?) sand and gravel deposits oriented northeast between Reed Lake and The Pas Moraine, and two sand plains north of Reed Lake (Fig. 2.5).

As part of the 1983-1988 Canada-Manitoba Mineral Development Agreement, regional surficial mapping (scale of 1:250 000) was completed in the northernmost part of the study area (NTS 63N/1 to N/4) (Kaszycki and Way Nee, 1990) and in the Cormorant Lake area (NTS 63K) (Clarke, 1989). Based on the observation of late striae directions and slightly calcareous tills in unleached road cuts north of the study area, Kaszycki (1989) observed that the zone of convergence between Keewatin and Labradorean ice was once located along the Leaf Rapids Interlobate Moraine (LRIM) to the north (Fig. 2.3), $100 \mathrm{~km}$ west of the Burtnwood-Etawney morainic system. This morainic system was traditionally thought to mark the zone of confluence between the two ice masses during the last glaciation (Klassen, 1983; Prest, 1983) (Fig. 1.1). However, she also reported that the LRIM extended only as far south as the High Rock Moraine (eastern extension of Cree Lake Moraine), and 


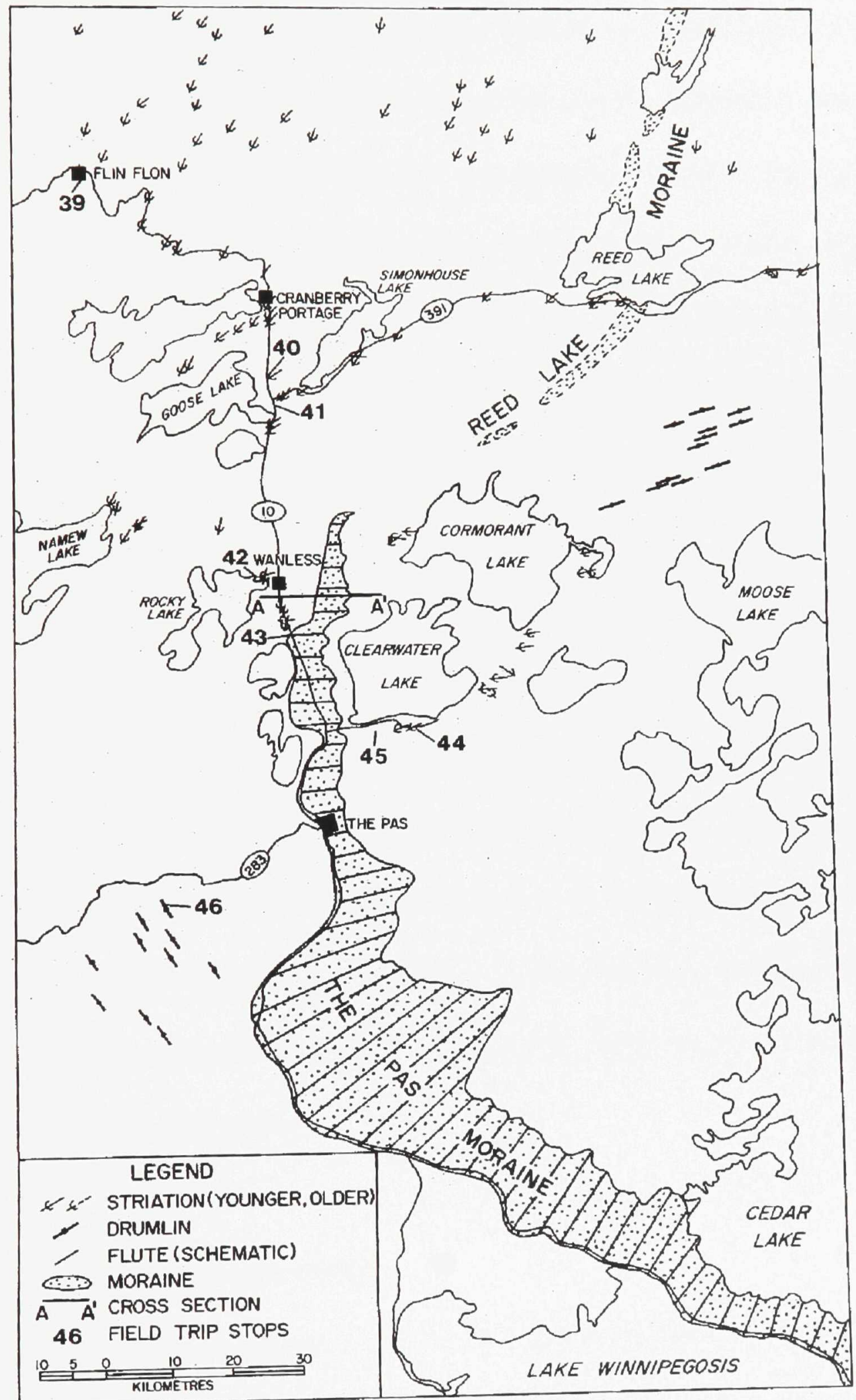

Figure 2.5 Main surficial geology features of The Pas area (from Nielsen and Groom, 1989). Southeasterly oriented drumlins discussed in text are located at field trip stop \#46, west of The Pas. 
that there was no evidence south of this position for a zone of convergent ice flow during deglaciation. Therefore, Kaszycki (1989) suggested that the interlobate system had not develop until the ice margin had retreated to this position. In the Cormorant Lake area, Clarke (1989) identified a sequence of ice flow events including an early westward flow, followed by a Keewatin ice advance from the north, and a final "Hudson" (Labradorean) ice advance from the east. Unlike Kaszycki (1989), Clarke suggested that the Reed Lake Interlobate Moraine was an extension of the LRIM, and found no evidence for correlation to The Pas Moraine.

In Saskatchewan, the Quaternary geology of the Amisk Lake area (NTS 63L, K) and the Pelican Narrows area (NTS 63M, N) was mapped and discussed on a reconnaissance scale (Schreiner, 1984a, 1984b). Schreiner (1984a) identified two major till units over the Shield portion in Saskatchewan: 1) a sandy till, derived from glacial erosion of local bedrock and pre-existing glacial deposits, and 2) a clayey till, rich in montmorillonite, derived, at least in part, from the lacustrine sediments of Lake Agassiz, suggesting it was deposited during a readvance into the lake basin.

\subsubsection{Recent surficial geology studies}

Recent studies conducted as part of the NATMAP Shield Margin Project (19911995), the Canada-Saskatchewan Partnership Agreement on Mineral Development (19921995), and the EXTECH I Snow Lake Subprogram (1990-1991) have concentrated on surficial mapping (Campbell and Henderson, 1997; Campbell et al., 1997, 1998; McMartin, 
1993a, 1994a, 1997a, 1997b, 1997c, 1998, 1999a; McMartin and Boucher, 1995; McMartin et al., 1995) and till provenance (Gobert and Nielsen, 1991; Henderson, 1995a, 1995b; Henderson and Campbell, 1992, 1994; McMartin, 1993b, 1994b, 1994c; McMartin and Campbell, 1994, McMartin et al., 1996; Nielsen, 1992, 1993, 1994). Figure 2.6 illustrates the different areas of responsibilities and the list of major contributors involved in the most recent surficial geology programs. Till and humus geochemical sampling programs have led to drift prospecting studies with reference to base metals (Henderson, 1995a; Kaszycki and Hall, 1996; Kaszycki et al., 1996), gold (Henderson, 1995a; Henderson and Roy, 1995) and diamonds (McMartin and Pringle, 1994), and to environmental studies related to the impact of the smelter (Henderson and McMartin, 1995; Henderson et al., 1998; McMartin et al., 1999). The interpretations presented in this chapter are largely based on data collected and published as part of the NATMAP Shield Margin Project, but incorporate the results from the work undertaken under the other surficial geology programs.

\subsection{Methods}

\subsubsection{Field methods}

Field activities related to the understanding of the glacial record consisted mainly of surficial geology mapping, detailed mapping of erosional ice flow indicators, and till sampling. Stratigraphic work was based largely on observations made in hand-dug pits when drift sampling and at a limited number of backhoe excavations. Exposures along road cuts, in borrow pits and in sand and gravel pits were rare but informative in terms of sedimentary structures, spatial and vertical variability in unit thickness, texture, and composition. Natural 


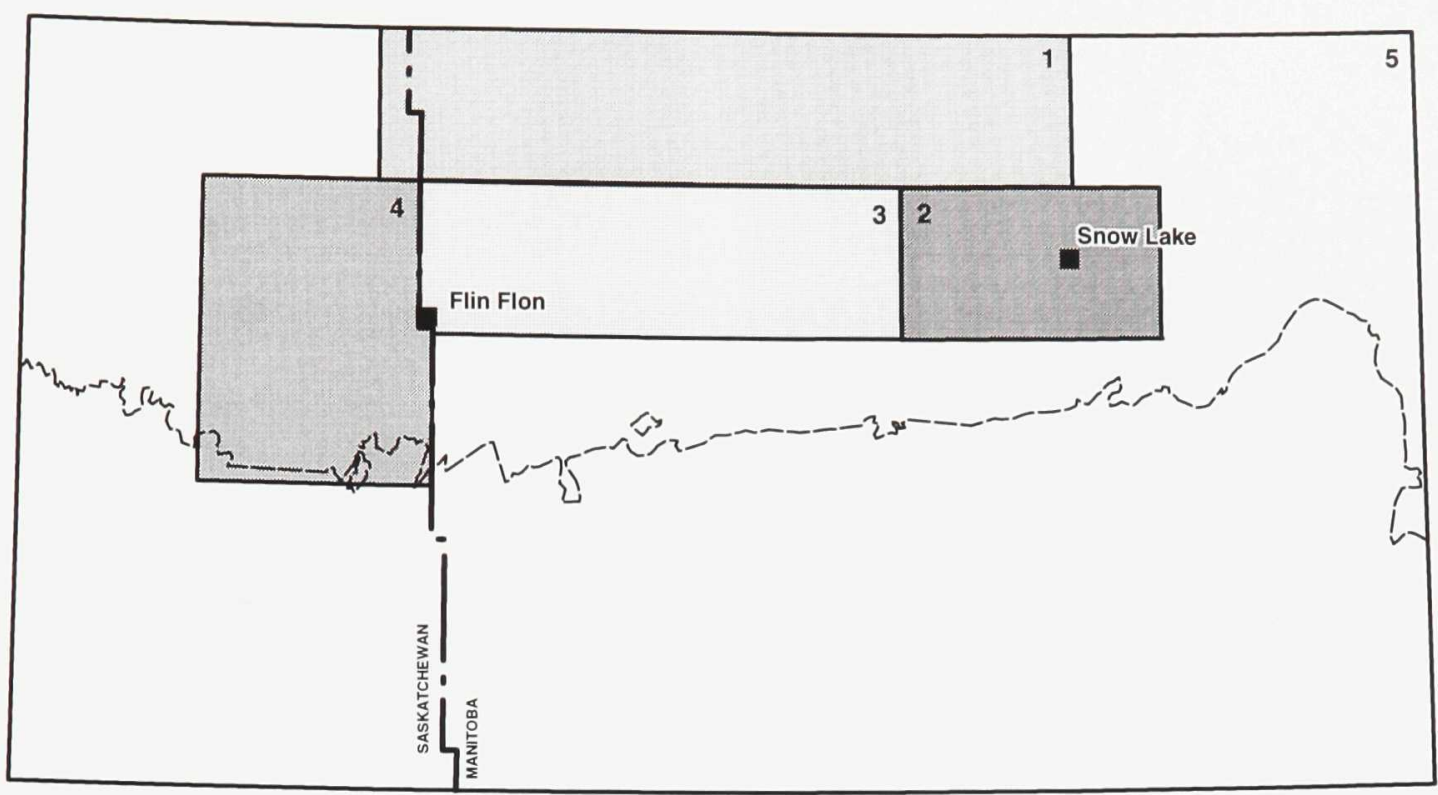

\section{LEGEND}

$\square$ 1. Manitoba MDA - regional survey, 1983 to 1988 , Christine Kaszycl

$\square$ 2. Snow Lake EXTECH area, 1990-1991, Christine Kaszycki, Erik N

$\square$ 3. Elbow Lake, Naosap Lake, Flin Flon areas, 1992 to 1995, Erik Ni

$\square$ 4. Annabel Lake - Amisk Lake area, 1992 to 1995, Penny Henderso

5. NATMAP Shield Margin area, 1991 to 1995, Isabelle McMartin

Figure 2.6 Areas of recent Quaternary geology programs in the Flin Flon region and major contributors. 
sections were rarely encountered. Nearly 2500 sites were visited and described systematically (McMartin et al., 1996, Appendix I).

\subsubsection{Ice flow indicator mapping}

Systematic, ice flow indicator mapping was carried out in the study area. Field measurements of nearly 2400 ice-inscribed, small-scale features on outcrops from 1216 sites are reported (McMartin et al., 1996, Appendix II). Most of these sites were documented as part of the most recent surficial geology programs but also include 112 sites from other sources compiled prior to 1990. Erosional features consist of glacial striations, grooves, rat tails, crescentic gouges and fractures, chattermarks, and roches moutonnées of varying scales. Direction of ice flow was derived from rat tails, crescentic features, roches moutonnées, and from stoss and lee topography. Relative ages of striated facets were interpreted based on the following criteria: 1) a set located in a lee-side position relative to another, is usually older (Fig. 2.7a), 2) a set just touching the top parts of the outcrop will have been formed by the youngest movement, and 3) a set preserved only in depressions and other low positions may be interpreted as being older (Lundqvist, 1990). In addition, a deeper set (groove) is usually older than a finer set (microstriae) (e.g., Syverson, 1995). Depositional ice flow indicators included all streamlined landforms, mainly drumlins, crag-and-tail hills and flutings. Till pebble fabrics were also measured at selected sections and the preferred clast orientation was evaluated using the eigenvector method of Mark (1973). 

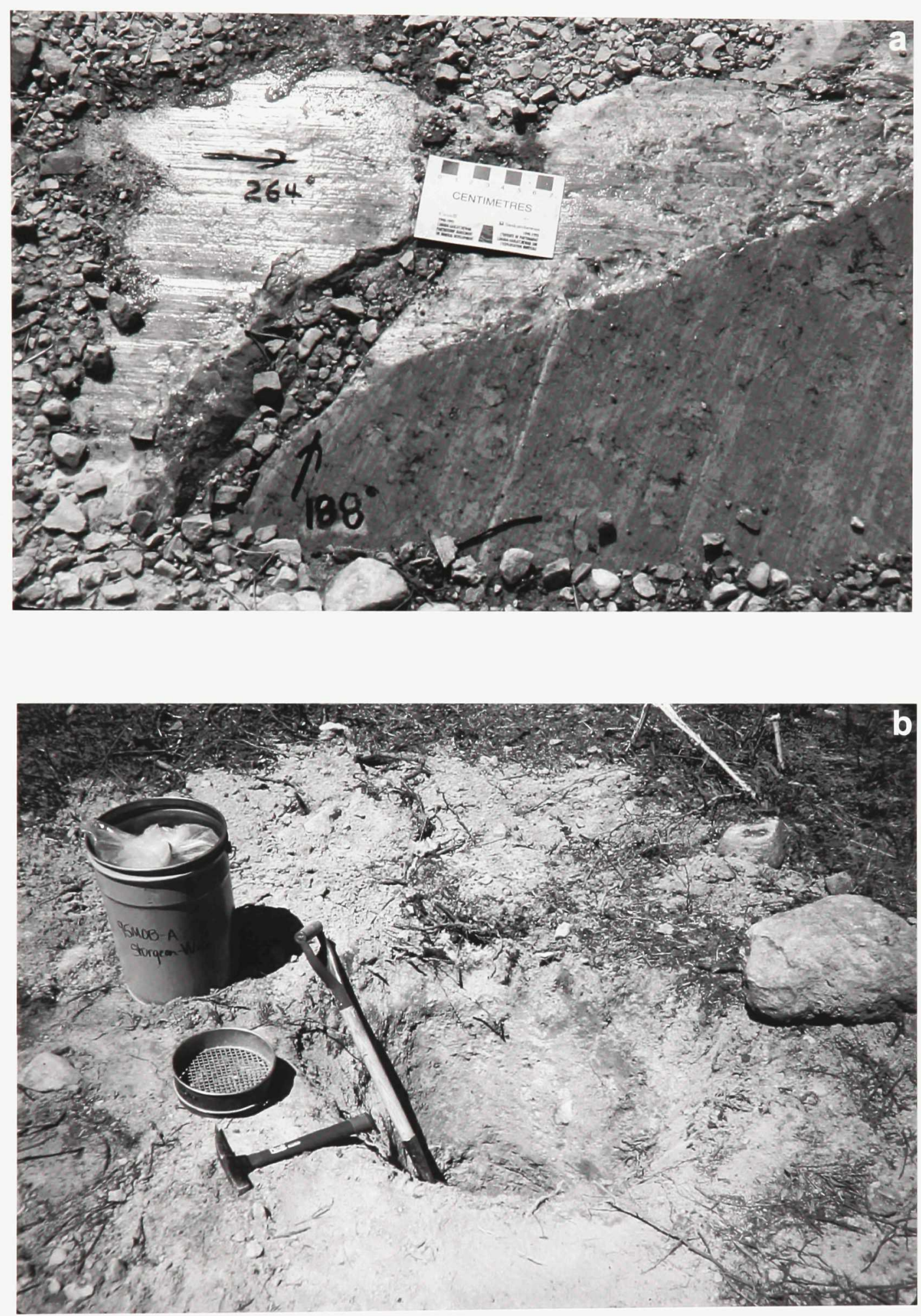

Figure 2.7 Photographs of (a) cross-cutting striated facets east of Cranberry Portage indicating a southerly flow $\left(188^{\circ}\right)$ post-dated by a westerly flow $\left(264^{\circ}\right)$, and (b) hand dug hole in till along Highway 106 near Sturgeon-Weir River. 


\subsubsection{Till sampling}

Till was systematically sampled in the Flin Flon region for glacial transport studies, geochemical mapping related to drift prospecting, and environmental studies. A total of 2536 till and other diamicton samples have been collected in the project area since 1984, including 1817 samples since 1991 when the NATMAP Program started. Only the unsorted to poorly sorted diamictons deposited as basal till at the ice margin or beneath the glacier are discussed in the present chapter. Diamictic units occurring within stratified sequences and interpreted as debris flows are not considered here, neither are glaciolacustrine diamictons. The complete database compiled from all available field and analytical data related to the surficial geology of the project area was published in a GSC Open File Report (McMartin et al., 1996). At each site, two 3-kg till samples were collected in the upper C horizon of soils, at approximately 75 to $100 \mathrm{~cm}$ depth (Fig. 2.7b), for texture, clast composition, carbonate content, qualitative colour, geochemistry, clay mineralogy, and archiving. Sample density of about 1-2 samples per $100 \mathrm{~km}^{2}$ was increased to 3 to 4 samples per $100 \mathrm{~km}^{2}$ in areas of road and trail access, and along shorelines. In addition, several excavated exposures in till were sampled in detail to examine weathering profiles and document stratigraphy, at 10 to $50 \mathrm{~cm}$ depth intervals.

\subsubsection{Sample preparation}

In the field, approximately one-third of a $3 \mathrm{~kg}$ till sub-sample was air-dried and dry sieved using a stainless steel 230 mesh screen to obtain the $<0.063 \mathrm{~mm}$ fraction for carbonate analysis. The remainder of the sample was wet-sieved to collect the 4-8 $\mathrm{mm}$ fraction for 
pebble counting. In the laboratory, approximately 300 to $500 \mathrm{~g}$ of material from the second $3 \mathrm{~kg}$ till sub-sample was used for geochemical analysis and clay mineralogy. The clay size fraction $(<0.002 \mathrm{~mm})$ was separated by centrifugation and decantation in a $5 \mathrm{~g} / \mathrm{l}$ solution of sodium hexametaphosphate at the Geological Survey of Canada (Lindsay and Shilts, 1995). Approximately $500 \mathrm{~g}$ of the remaining material was used for textural analysis; the remainder of the sample was archived.

\subsubsection{Analytical methods}

The lithologic composition of the granule fraction of till (4-8mm) was visually determined and counted using approximately 300 pebbles (maximum). Samples collected in the Amisk Lake area $(\mathrm{n}=349)$ were weighed and the results expressed as $\%$ weight of the total sample (Henderson, 1995a). Lithologies were divided into 3 groups: Paleozoic carbonates (mainly dolomite), Paleozoic sandstones (Winnipeg Fm), and Precambrian rocks (intrusive, volcanic and metamorphic).

The silt plus clay $(<0.063 \mathrm{~mm})$ fraction of most till samples was analysed for total carbonate content, using atomic absorption spectrometry (AAS) following digestion in 1:1 hydrochloric acid solution using the method of Ross (1986). For comparison, samples collected in 1991 were analysed for carbonate content using a Leco induction furnace (Foscolos and Barefoot, 1970; Shilts and Kettles, 1990). The atomic absorption method is designed to measure calcium and magnesium ions in the filtrate of acid-leached samples. These ions are derived from the carbonate minerals of calcite and dolomite, and from any 
other soluble $\mathrm{Ca}$ or Mg-bearing minerals which may be present in the sample (e.g., phyllosilicates). Tills derived from Precambrian lithologies can therefore contain a relatively high amount of "total carbonate" when analysed by AAS as compared to analysis by Leco (equivalent $\% \mathrm{CaCO}_{3}$ ). Figure 2.8 illustrates the comparison of results between the two methods. At generally low carbonate content $(<10 \%)$, the AAS method gives slightly higher percentages, while in moderately to highly calcareous tills $(>20 \%)$, the Leco method provides higher values, with an apparent carbonate equivalent content exceeding $100 \%$ in one sample.

Approximately $1 \mathrm{~g}$ of the clay-size fraction of till was analysed for a number of major and trace elements (Ag, Al, As, Ba, Bi, Ca, Cd, Co, Cr, Cu, Fe, Hg, K, La, Mg, Mn, Mo, Na, $\mathrm{Ni}, \mathrm{P}, \mathrm{Pb}, \mathrm{Sb}, \mathrm{Sc}, \mathrm{Sr}, \mathrm{Ti}, \mathrm{V}$, and $\mathrm{Zn}$ ) using ICP-AES (inductively coupled plasma atomic emission spectrometry) after a hot acid leach in aqua regia solution. Mercury was determined using cold-vapour atomic absorption spectrometry (CV-AAS) following aqua regia digestion. Analysis of duplicate samples and laboratory standards was used to monitor analytical accuracy and precision (McMartin et al., 1996).

The mineralogy of till $(<0.002 \mathrm{~mm})$ was determined at the Geological Survey of Canada, using a Philips PW 1710 automated powder diffractometer equipped with a graphite monchromater, $\mathrm{CoK} \alpha$ radiation at $40 \mathrm{kV}$ and $30 \mathrm{~mA}$. The samples were also x-rayed following saturation with ethylene glycol and heat treatment $\left(550^{\circ} \mathrm{C}\right)$.

Grain size analysis was carried out on the $<2 \mathrm{~mm}$ (-10 mesh) fraction separated by 
Total Carbonate Content

(\%)

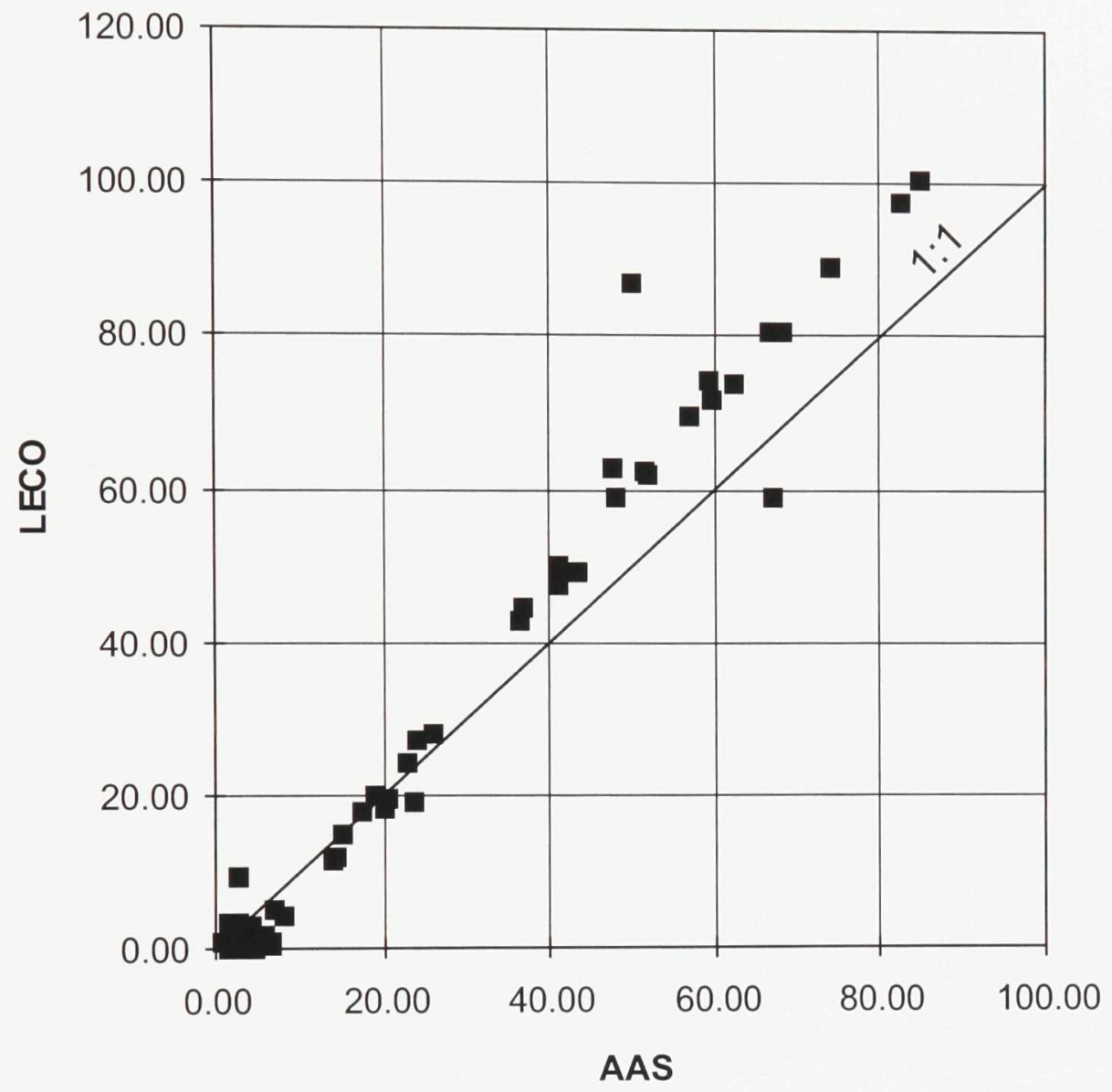

Figure 2.8 Relationship between total carbonate content of the $<0.063 \mathrm{~mm}$ fraction of till analyzed by Atomic Absorption Spectrometry (AAS) versus Leco $(n=89)$. Non calcareous till derived from Precambrian lithologies $\left(0 \% \mathrm{CaCO}_{3}\right.$ by Leco) can contain as much as $4 \%$ of 'total carbonate' by AAS. 
dry sieving. The sand fraction $(0.063-2 \mathrm{~mm})$ was separated from the silt and clay fractions by dry sieving (+ 230 mesh). The silt and clay fractions (-230 mesh) were determined by pipette analysis. The results were calculated as a percentage weight of the $<2 \mathrm{~mm}$ fraction.

\subsection{Glacial erosional record}

Ice flow indicators include erosional and depositional features. Glacial erosional features reflect not only late glacial shifts in ice flow but a history of previous ice flow events. Depositional streamlined landforms primarily reflect late glacial ice flow patterns (e.g., Boulton, 1976), although consistent with the striation record, crosscutting relations among landforms indicate that some could be much older, possibly pre-dating the LGM (Boulton and Clark, 1990). In the Flin Flon region, the small-scale erosional features observed on the bedrock surfaces were formed, in most cases, from the scouring action of sliding basal ice. Sculpted bedrock erosional forms or S-forms (e.g., Shaw, 1988) ranging in size from a few centimetres to a few metres were occasionally observed in the area, mainly on Precambrian lithologies, within or adjacent to glacial meltwater corridors, or along the shores of large lake basins. They are commonly associated with parallel glacial striations. Their distribution and character suggest they were formed by subglacial meltwater flows (Sharpe and Shaw, 1989; Kor et al., 1991) that spanned the major meltwater routes. Their significance to drift composition and dispersal is unknown.

\subsubsection{Relative chronology}

The glacial erosional record of the Flin Flon region reflects the complexity of ice flow 
events that occurred in a zone of confluence between Keewatin and Labrador Sector ice masses (Fig. 2.9). Several regional ice flow trends have been documented, and these have been divided on the basis of their provenance, Keewatin or Labradorean, and will be discussed chronologically, from oldest to youngest for each Sector.

\subsubsection{Keewatin Sector events}

\section{1) Early southeastward flow}

The oldest ice flow of Keewatin provenance recorded in the region came from a centre of outflow that was located to the northwest of the study area. Deeply incised, isolated, southeast trending striae $\left(\right.$ mean $\left.=148^{\circ}\right)$ are found on both sides of the Shield margin suggesting that the entire region was once occupied by ice of Keewatin provenance (Fig. 2.10). Early southeasterly striae have been recorded north (Dredge et al., 1986; Dredge and Nixon, 1992; Kaszycki, 1989) and south (Tyrrell, 1892; Klassen, 1967) of the study area, and further to the northeast in the Gillam area below an older till unit deposited by ice flowing southeast (Nielsen et al., 1986; Roy et al., 1995).

\section{2) Early southward flows}

On Precambrian bedrock and in the centre of the Paleozoic cover, early, southerly striae $\left(\right.$ mean $\left.=184^{\circ}\right)$ are preserved on surfaces truncated by later southwesterly flows. This early flow likely spanned the entire project area but it is mainly preserved in the Amisk Lake and Jan Lake areas in Saskatchewan (McMartin et al., 1996). In addition, occasional southwestward ice flow indicators $\left(\right.$ mean $\left.=217^{\circ}\right)$ crosscut the early southerly striae or are 


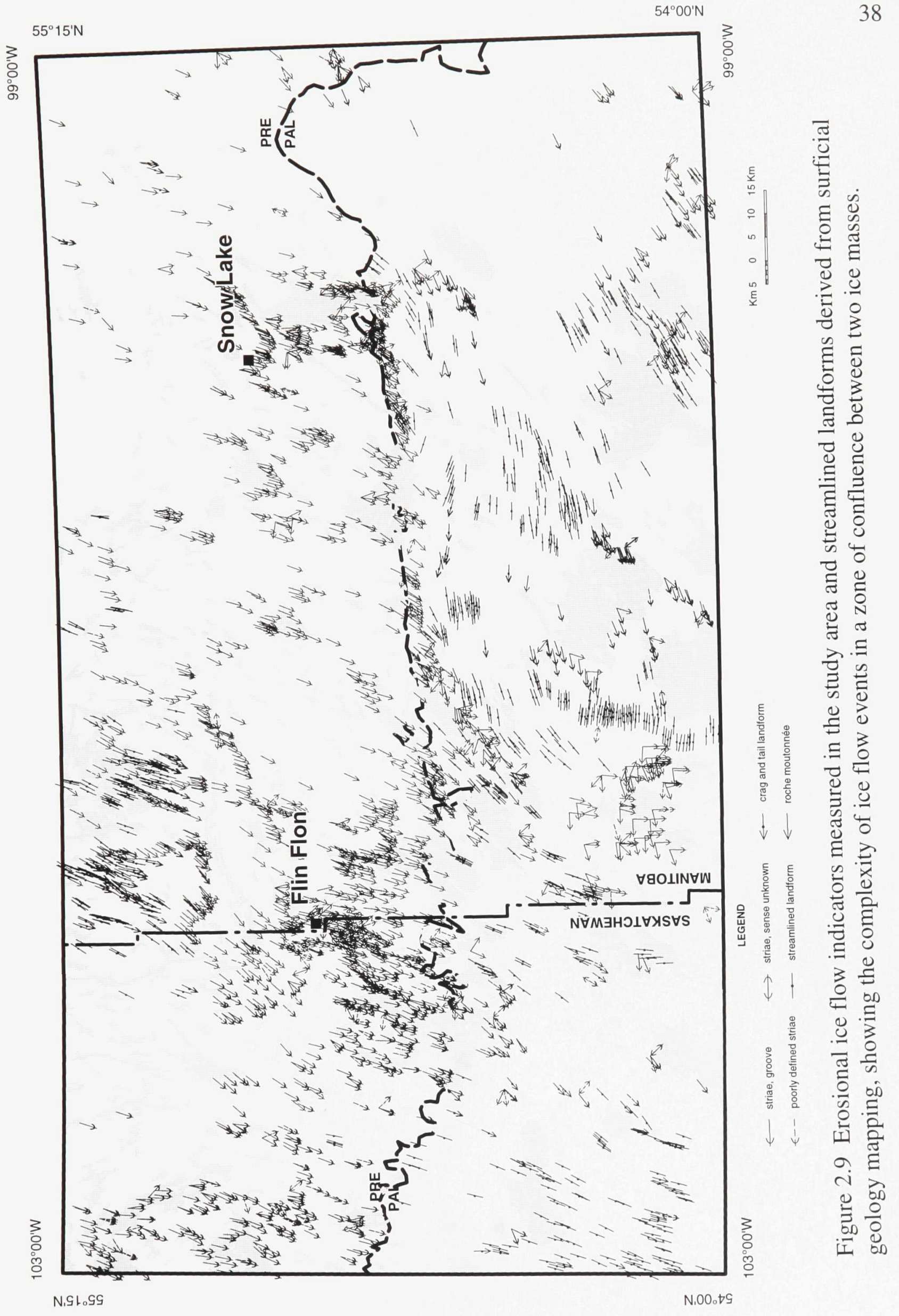




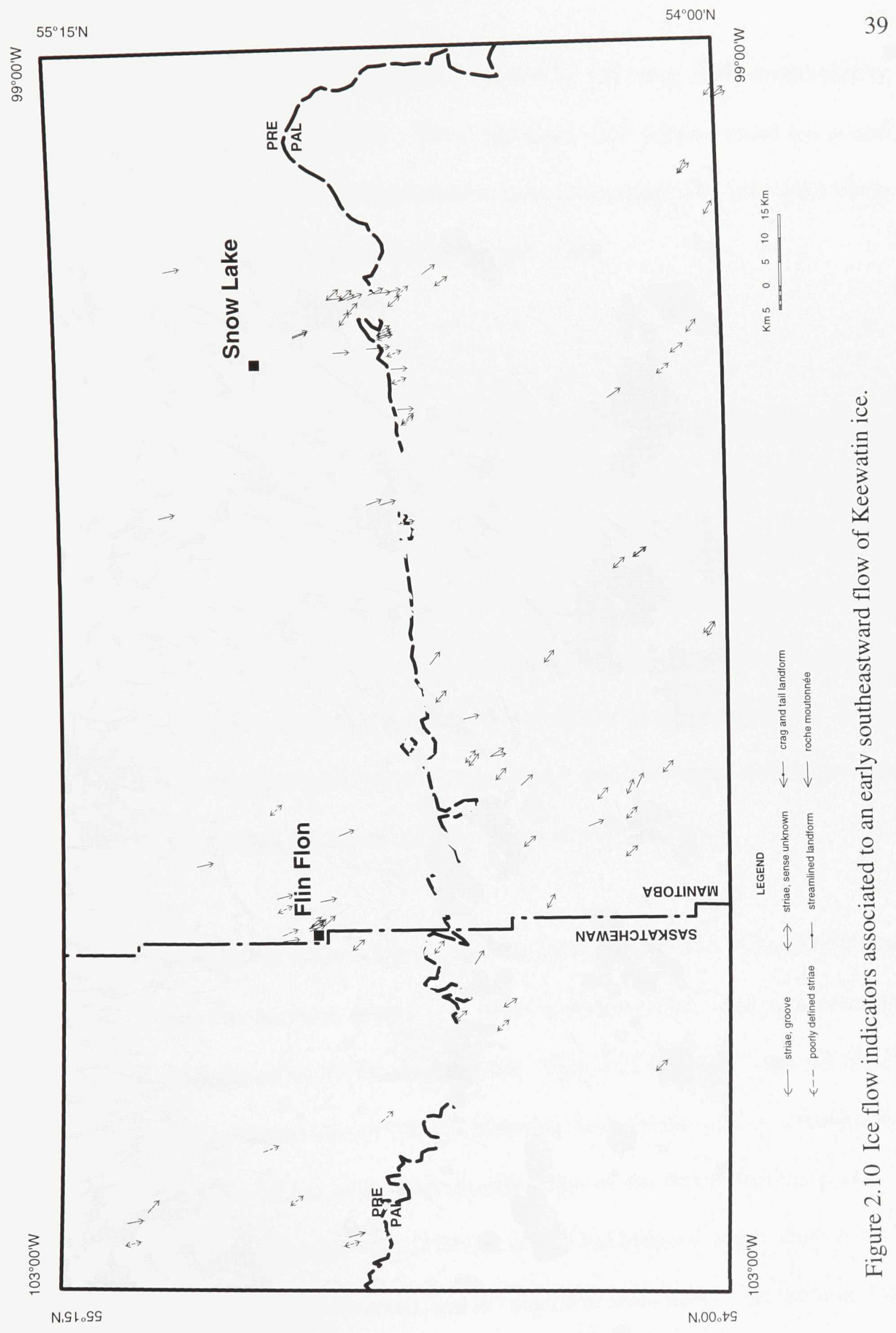


preserved on the protected sides of surfaces striated by the main south-southwesterly Keewatin ice flow event (see below). These pre-main, well defined striae are found primarily in the Amisk Lake and Athapapuskow Lake areas suggesting they were likely formed during a local ice flow event (McMartin et al., 1996).

\section{3) Main south-southwestward flow}

On the Shield, striations, grooves, roches moutonnées, and crag and tail landforms have a predominant direction toward the south-southwest $\left(\right.$ mean $=201^{\circ}$ ), indicating glaciation from a Keewatin Sector dispersal centre (Fig. 2.11). Local variations of this main ice flow are sometimes found around steep outcrops and in narrow valleys, providing evidence of a strong influence by the underlying local topography. However, on a regional scale, ice flow indicators are strongly aligned in the same south-southwest direction. These ice flow features are regionally pervasive over the Shield, to the north and west of the study area, and are interpreted as part of the main last Wisconsinan glaciation.

Over the Paleozoic cover, evidence for this south-southwestward flow differs on either side of The Pas Moraine (Fig. 2.11). West of the moraine, south-southwesterly striations and streamlined landforms are dominant. They shift from $210^{\circ}$ near the Shield margin to $179^{\circ}$ immediately west of The Pas Moraine. South-southwesterly striations are also predominant in a $10 \mathrm{~km}$ wide band directly south of the Shield boundary east of Cranberry Portage, and trend $206^{\circ}$ to $214^{\circ}$. East of The Pas Moraine, south-southwesterly ice flow indicators were rarely observed, and in contrast to areas west of the moraine, they 


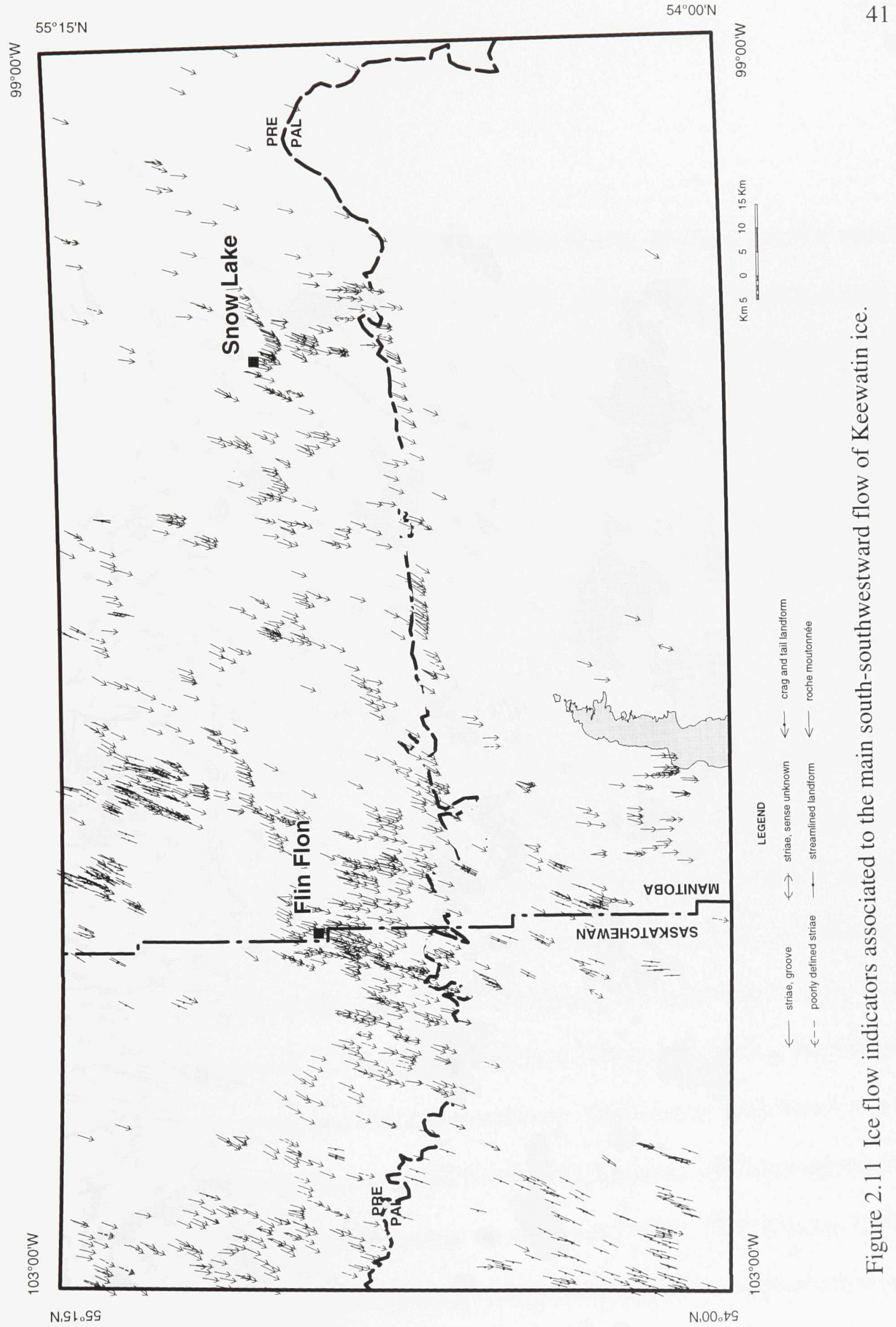


are post-dated by Labradorean ice flow indicators.

\section{4) Late southwestward flow}

The youngest flow of Keewatin ice is recorded by fine striations trending more westerly $\left(\right.$ mean $=220^{\circ}$ ) than the main event (Fig. 2.12). These striae are found in several areas over the Shield and in a confined area west of The Pas Moraine. They are pervasive in a few areas, namely north of the Annabel Lake Moraine, south of Amisk Lake, south of Cranberry Portage, and along the Shield margin east of Reed Lake. They are also found as far north as the High Rock and Cree Lake Moraines (Kaszycki, 1989).

\subsubsection{Labrador Sector events}

\section{1) Early westward flow}

The oldest flow of Labradorean ice in the region was westward from a dispersal centre located east of the project area (Fig. 2.13). Deeply incised westerly striae and crescentic gouges were recorded sporadically across the entire study area $\left(\right.$ mean $\left.=272^{\circ}\right)$, predominantly preserved or differentiated in the Rocky Lake area on resistant "table top" outcrops of the upper Stony Mountain Fm. In the Amisk Lake area, striae trending 270 were measured at the base of a $2 \mathrm{~m}$ deep excavation in till (Henderson, 1995a). The western extension and the age of this westward flow is unknown. Old westerly striae were found at a few sites in northern Manitoba (Dredge and Nixon, 1992; Kaszycki, 1989), in north-central Saskatchewan (Johnston, 1978), and south of the study area (Tyrrell, 1892; Klassen, 1967). The age relationship observed between these westerly striae and the old southeasterly striae 


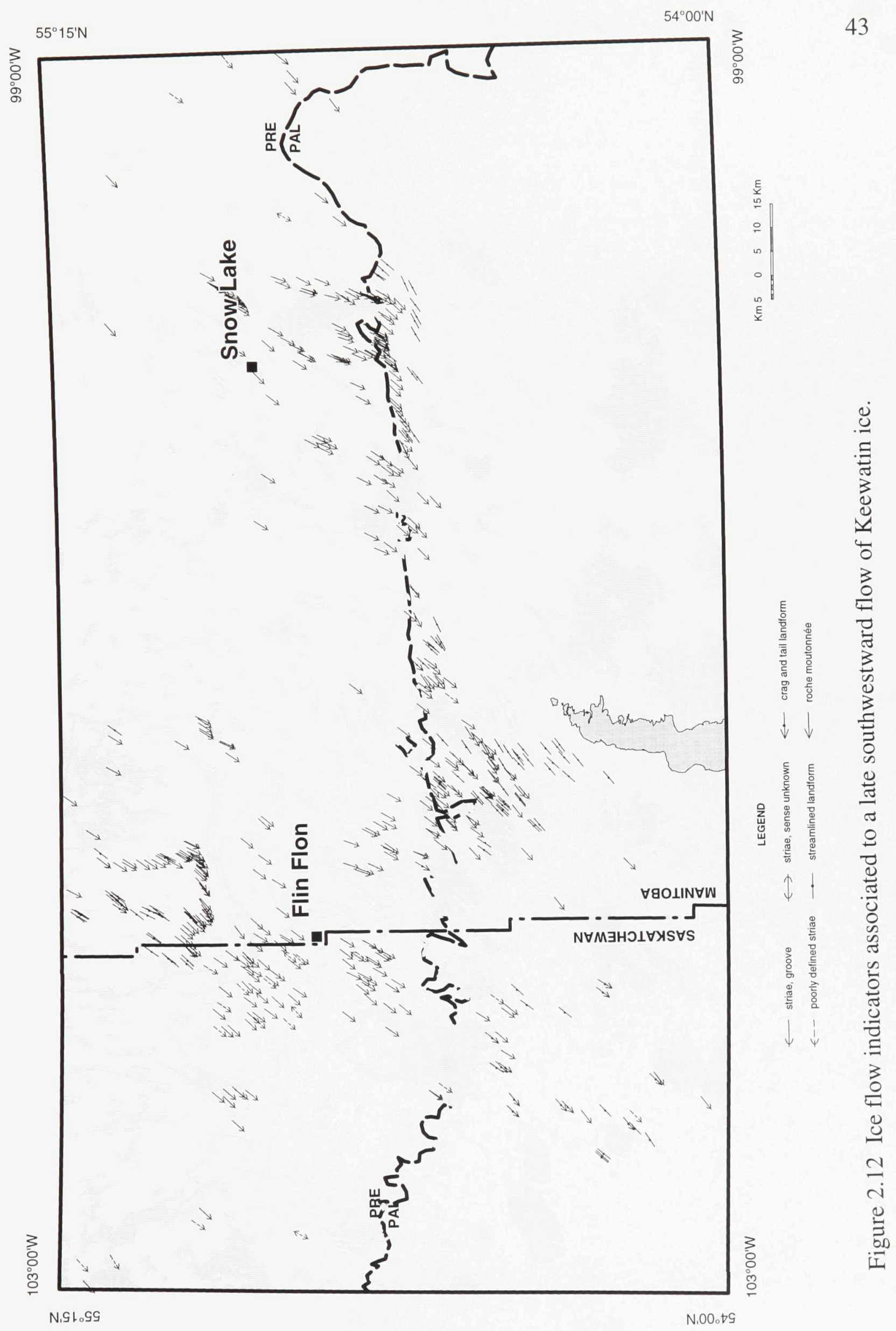




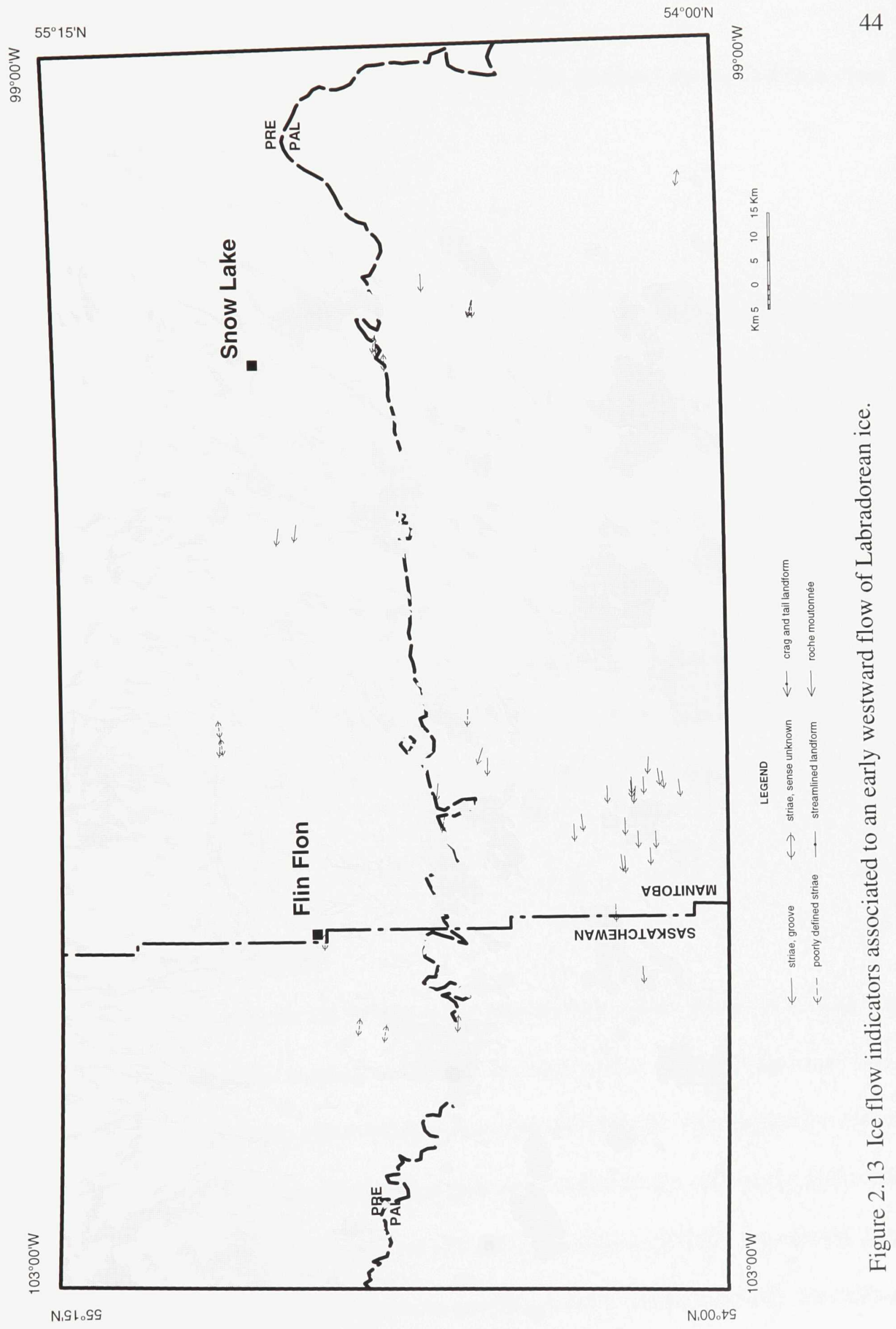


of Keewatin provenance suggests that the westerly flow predated the earliest flow from Keewatin.

\section{2) Main radial flow}

A radial pattern of ice flow defined by striations, grooves, crescentic fractures and drumlins, and terminating at the arcuate The Pas Moraine, converges $250 \mathrm{~km}$ up-ice in the Sipiwesk Lake area (Fig. 2.14). Ice flow trends radially from $268^{\circ}$ at the Shield margin to $224^{\circ}$ in the southern part of the study area. This lobate pattern of ice flow truncates other landforms and striae of Keewatin provenance. Parallel west-southwesterly striae are found west of The Pas Moraine, as far west as Namew Lake in Saskatchewan; however, in this area, they are post-dated by southerly flows of Keewatin ice. The striation record therefore suggests that the northern tip of The Pas Moraine in the region marks an interlobate position between Keewatin and Labradorean ice during deglaciation when Labradorean ice had retreated to the moraine.

\section{3) Late shifts in the radial flow}

A clockwise shift in ice flow trend is recorded in a large area east of The Pas Moraine, where westerly trending striae and drumlins $\left(\right.$ mean $=274^{\circ}$ ) post-date westsouthwesterly trending striae of Labradorean provenance (Fig. 2.15). This slight but constant deviation is even more pronounced immediately south of Reed Lake, and on top of The Pas Moraine where drumlins and flutings are aligned to the west-northwest. Occasional, late, west-northwesterly striations have also been recorded in the Wekusko Lake area. In contrast, 



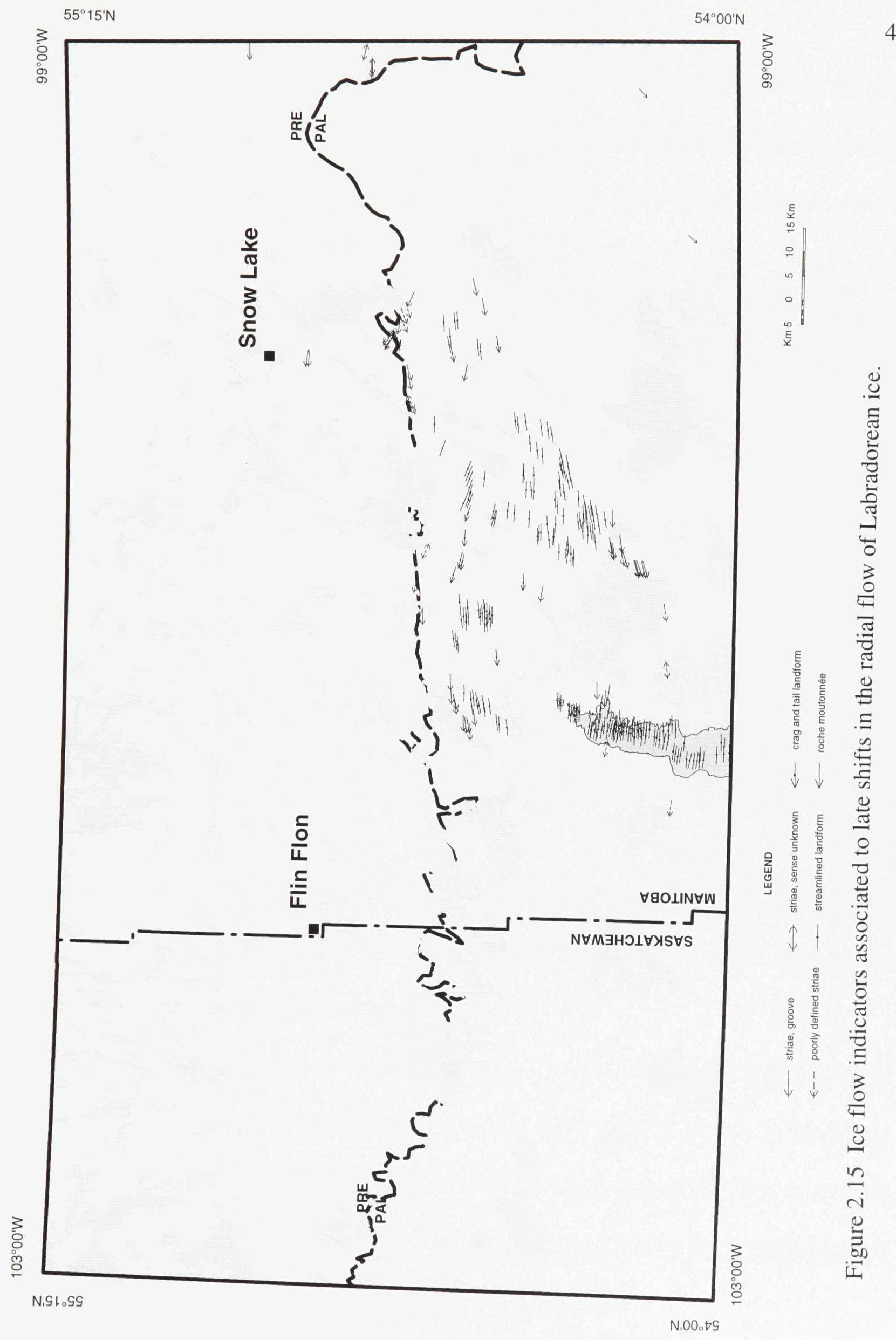


a counter-clockwise shift in ice flow direction is recorded in the southern part of the study area. This late shift in the radial flow is the same flow that extends beyond The Pas Moraine at Grand Rapids and spans the Interlake area east of the Manitoba Escarpment ("Arran Readvance”: Klassen, 1979).

2.5.2 Summary of relative ice flow chronology

A wide variety and orientation of ice-inscribed features on bedrock surfaces indicate the direction of successive glacial advances and final retreat of the last two ice masses in the region. Two distinct regional ice movements prior to the LGM, and a complex sequence of ice flows that occurred during and after the LGM within the Keewatin and Labrador Sectors of the LIS are defined:

A) The earliest advance was to the west and spanned the entire study area and the surrounding regions in Manitoba and Saskatchewan, from a dispersal centre located east of the study area (Labrador Sector ice).

B) The westward flow was followed by a regional southeastward flow of Keewatin Sector ice, from an outflow centre located northwest of the study area, flowing across north-central Manitoba and east-central Saskatchewan (at least).

C) A clockwise shift in ice flow of Keewatin provenance was recorded over the entire study area, from a southeasterly to a south-southwesterly direction. Pervasive south-southwesterly ice flow indicators in north-western Manitoba and north-eastern Saskatchewan are thought to represent ice flow during the LGM. A zone of confluent and parallel ice flow between the two ice masses likely existed immediately east of the region. 
D) After the LGM, a lobe of Labradorean ice advanced over the Paleozoic cover at least to the Namew Lake area, and the zone of confluence between both ice masses shifted westerly to an unknown position in east-central Saskatchewan.

E) Labradorean ice retreated to The Pas Moraine, forming an arcuate ice front, and southward flowing Keewatin ice reoccupied areas underlain by Paleozoic bedrock west of The Pas Moraine. Hence, the zone of confluence shifted easterly to the moraine, marking a major north-south trending interlobate position during the early stages of deglaciation.

F) Late shifts in ice flow directions occurred within both Sector ice masses as they retreated out of the study area in front of Lake Agassiz. A shift to a more southwesterly flow of Keewatin ice occurred south of the Cree Lake-High Rock Moraines, as far south as Rocky Lake. This was followed by shifts in the radial flow of Labradorean ice which readvanced locally and fluted the areas previously covered by the ice front, including The Pas Moraine.

\subsection{Glacial depositional record}

Preservation of the glacial depositional record reflects differential erosion among succeeding ice flow events, and therefore, may or may not reflect all of the glacial and deglacial events suggested by the erosional record. Glacial deposits described here consist of unsorted to poorly sorted diamictons deposited as till by the direct action of glacial ice.

\subsubsection{Till morphology and extent}

\subsubsection{Precambrian terrain}

Till consisting of thin $(<2 \mathrm{~m})$, locally derived debris is the most common sediment 
over the Shield. Surface morphology in this area is for the most part controlled by the morphology of the underlying bedrock surface. The till forms a discontinuous cover that commonly thickens on the lee-side of bedrock knobs, forming $250 \mathrm{~m}$ to $2 \mathrm{~km}$ long, crag-andtail hills. Between bedrock knobs, till underlies relatively thin glaciolacustrine and organic deposits. Thicker till ( $>5 \mathrm{~m}$ ) is present in the north-central part of the region near Kississing Lake where drumlins and crag-and-tail landforms are scattered across the area (Fig. 2.9).

\subsubsection{Paleozoic terrain}

Over the Paleozoic, till thickness varies considerably, from 0 to $50 \mathrm{~m}$. Over resistant and thickly-bedded dolomitic mudstone that commonly forms prominent bedrock plateaus, till is thin but fairly continuous (Fig. 2.16). In areas of thicker till ( $>2 \mathrm{~m})$, streamlined landforms are more common, and topography is drift controlled (Fig. 2.17). Thick streamlined sediments composed of till (F. Haidl, Saskatchewan Energy and Mines, pers. comm., unpublished drill core data) occur in Saskatchewan over the Suggi Lake area, and extend southward to the edge of the Saskatchewan River floodplain. Numerous drumlin swarms composed of thick till covered by discontinuous glaciolacustrine deposits are also present in a wide area east (up-ice) of The Pas Moraine.

\subsubsection{The Pas Moraine}

The Pas Moraine is a prominent glacial landform in the region. North of Westray, the moraine decreases abruptly in width from about $25 \mathrm{~km}$ to $5 \mathrm{~km}$, and becomes northerly oriented (Fig. 2.3). There, its western side is indented into several large notches (cf. Fig. 


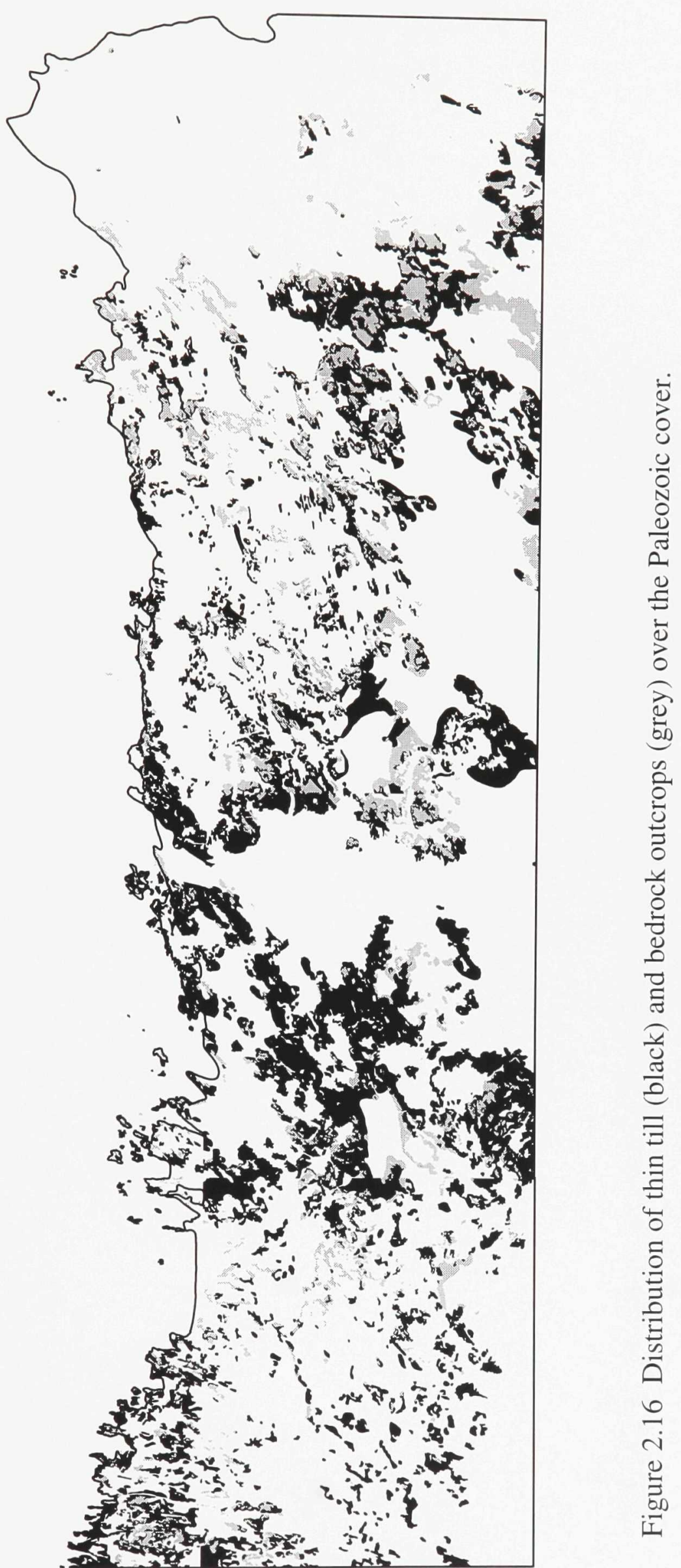




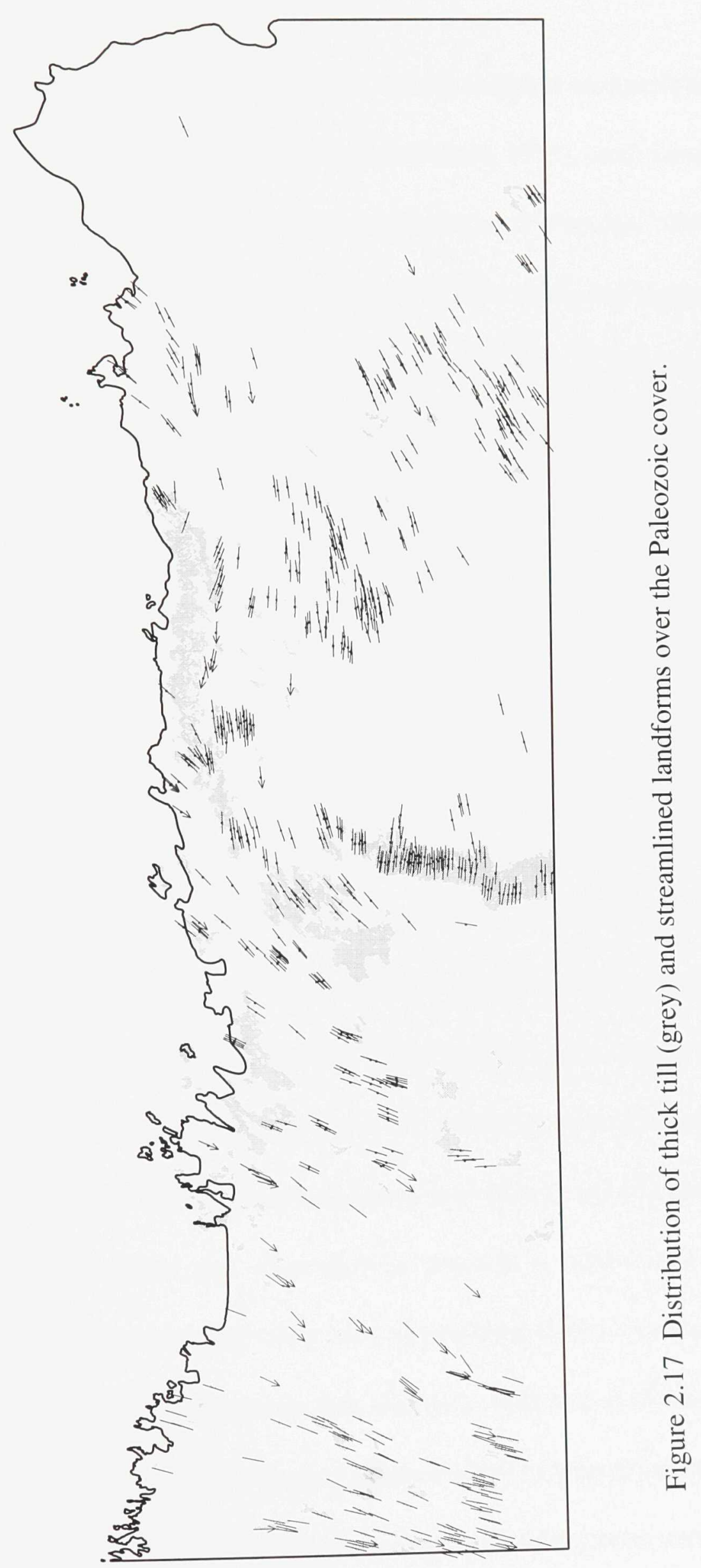


2.5). This morphology, together with the striation record, suggests an interlobate position for the northern tip of the moraine. Water well data (Pedersen, 1973), confidential drill hole data (Viljoen et al., 1996) and backhoe excavations (Singhroy and Werstler, 1980; McMartin et al., 1996) indicate that the moraine consists of till, up to $50 \mathrm{~m}$ thick, and represents a build up of sediment in a major depression in the Paleozoic bedrock north of Westray. Fluted till is found directly on top of the moraine, with flutings reaching $5 \mathrm{~km}$ in length and $10 \mathrm{~m}$ in height (Fig. 2.18). The flutings differ slightly in orientation (up to $20^{\circ}$ ) from early striations found immediately west of the moraine (Fig. 2.18).

\subsubsection{Reed Lake Interlobate Moraine}

Hummocky topography characterizes a $50 \mathrm{~km}$ long and $5 \mathrm{~km}$ wide east-west trending zone immediately south of the Shield margin in the Reed Lake area (Fig. 1.2); area where the late striae record suggests the confluence of Keewatin and Labradorean ice masses (Fig. 2.19). Hummocks and ridges up to $10 \mathrm{~m}$ high are found along this trend, interspersed with depressions filled with peat and clay (Fig. 2.20a). The hummocks are composed of boulders, pebbly gravels and very cobbly, highly calcareous till, underlain by southwesterly striated bedrock. The zone of hummocky terrain also includes large pitted sand and gravel deposits, occasionally capped by massive clay. One of these deposits is sandwiched between the hummocky terrain and a low morainic till feature streamlined to the west-northwest near Black Duck Lake (Fig. 2.19). It comprises thin diamictic beds and deformed and faulted cross-bedded gravel and rippled sand indicating a paleocurrent to the northwest (Fig. 2.20b). The clay cover suggests this material was deposited in a large subaqueous outwash fan near 


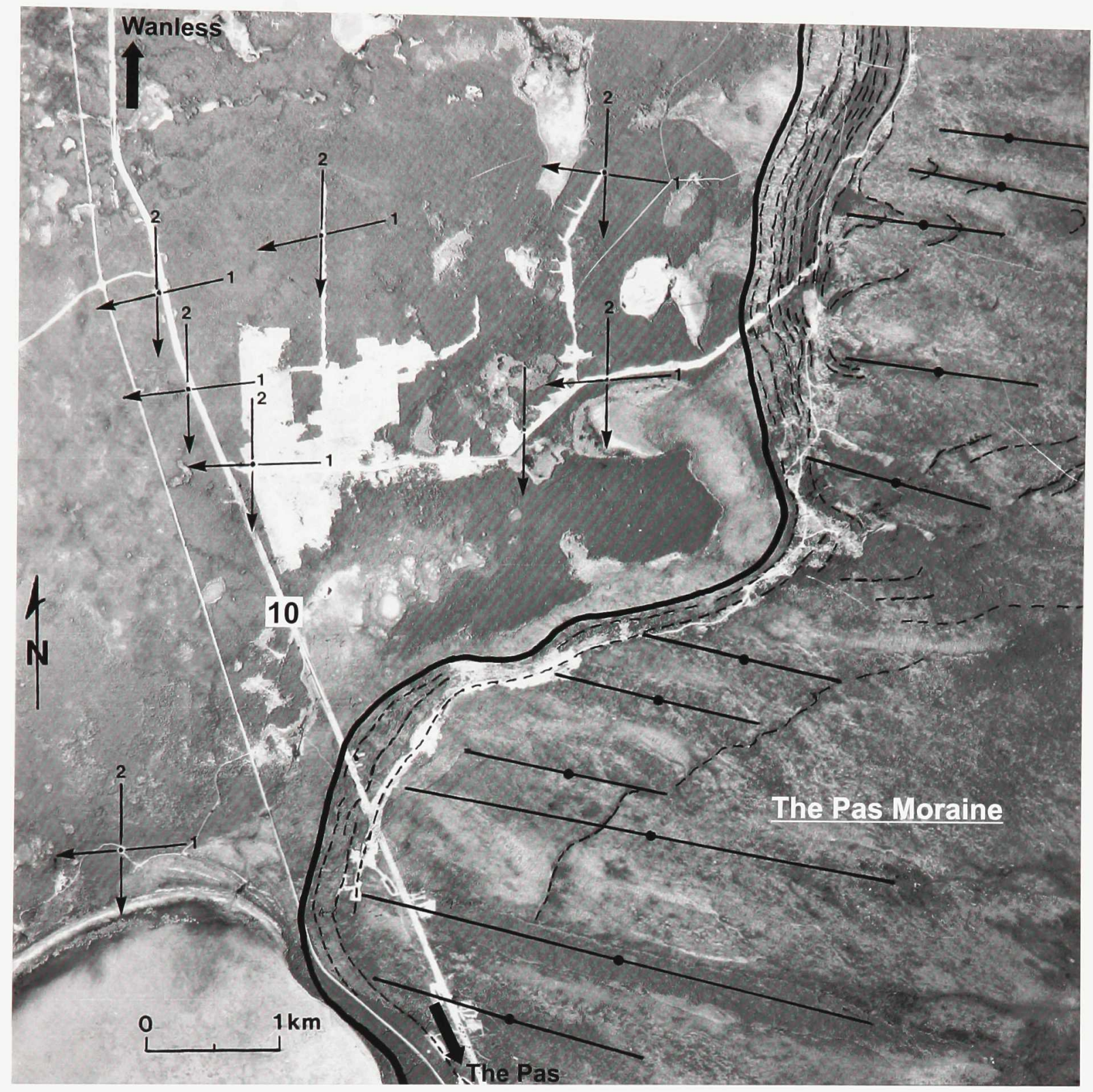

Figure 2.18 Aerial photograph of The Pas Moraine near Wanless showing streamlined till on top of the moraine. Striae directions are shown in front of the moraine. Flutings have a slightly different orientation from the westward striations. 


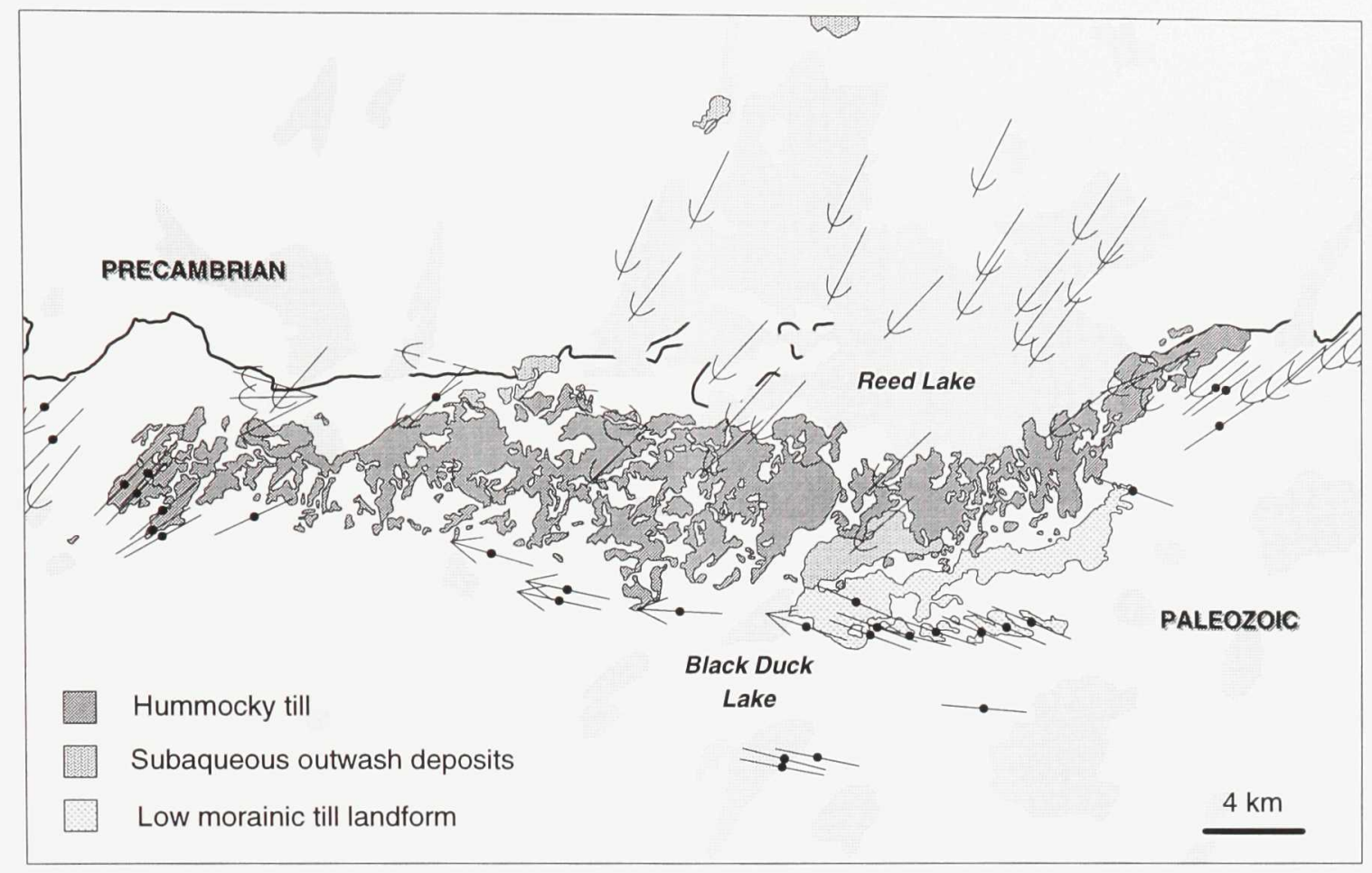

Figure 2.19 Geology of the Reed Lake Interlobate Moraine showing major deposits and late glacial ice flow indicators, which suggest the confluence of Keewatin and Labradorean ice masses. 

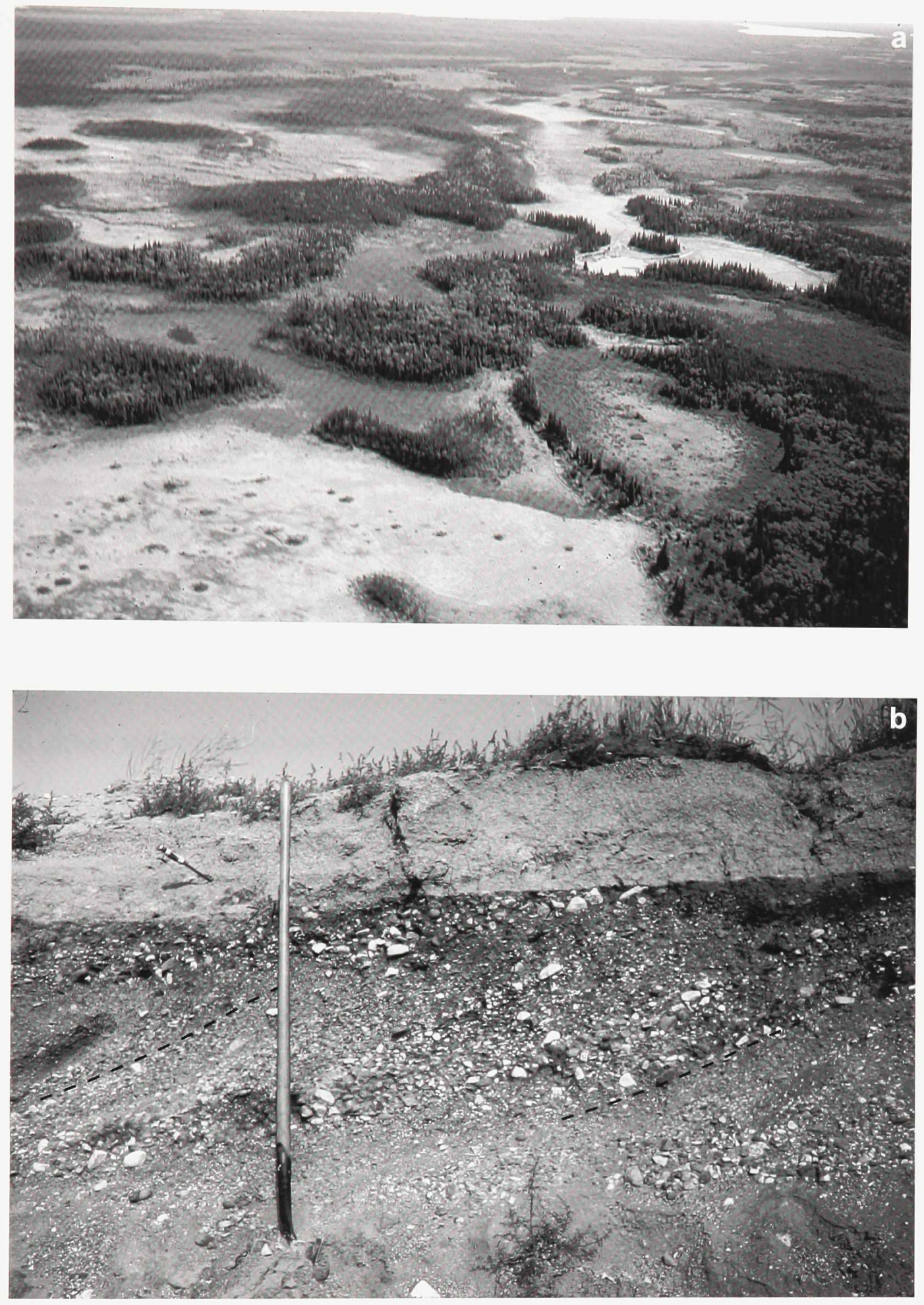

Figure 2.20 Photographs of (a) the Reed Lake Interlobate Moraine (taken from the air), and (b) section in sand and gravel deposit northeast of Black Duck Lake, indicating paleocurrent to the northwest, overlain by massive clay. 
the Labradorean ice front in a re-entrant of Lake Agassiz between Keewatin and Labradorean ice.

Only parts of the "morainic ridges" shown by Antevs (1931) lie within this hummocky terrain. The southwestern extension of this moraine to The Pas Moraine, as suggested by Nielsen and Groom (1987) (Fig. 2.5), is not supported by recent surficial mapping (McMartin, 1997c; McMartin and Boucher, 1995). The only sand and gravel deposits south of Black Duck Lake are thin $(<2 \mathrm{~m})$ littoral sediments deposited in beach ridges of Lake Agassiz. Furthermore, Nielsen and Groom (1987) included two sand plains north of Reed Lake as part of the interlobate moraine (Fig. 2.5). The lack of convergent striae on either side of these two deposits does not support such an interpretation. Similar north-south trending glaciofluvial deposits are found over the Shield and these are interpreted as a series of longitudinally overlapping subaqueous outwash sediments deposited in Lake Agassiz as meltwater flowed from subglacial conduits near the Keewatin ice front (Henderson and Campbell, 1994; McMartin, 1994c; Nielsen, 1993). This indicates that the Reed Lake Interlobate Moraine (RLIM) includes essentially the hummocky terrain and trends more westerly than the previous positions shown by Antevs (1931) and by Nielsen and Groom (1987).

\subsubsection{Hargrave Moraine}

The Hargrave Moraine (Tarnocai, 1970) is shown on glacial maps of Canada between Lake Winnipeg and Grass River (Prest et al., 1968; Fulton, 1995) (Fig. 2.3). However, the 
moraine is poorly defined in the study area. A low and broad plateau covered by fine grained glaciolacustrine sediments, behind which a radiating array of flat-topped eskers terminates, is found east of Hargrave Lake in the centre of the Grass River Basin (McMartin, 1999a). The related sediments have been vaguely described and interpreted as overridden material (e.g., Tarnocai, 1970; Klassen, 1986). They were not observed as part of this project.

\subsubsection{Characteristics of surface till}

In the study area, surface till has been modified by post-depositional processes, including (1) physical glaciolacustrine processes related to inundation and subsequent stepwise drainage of Lake Agassiz, such as iceberg scouring, wave and current washing of fines, and beach formation, and (2) surface weathering processes. As a result of glaciolacustrine processes, the top 20 to $40 \mathrm{~cm}$ of till is commonly reworked and lacks fine-grained material, or sometimes exhibits a boulder lag. On the other hand, the effects of surface weathering are mostly observed in the A and B soil horizons, typically extending to about $70 \mathrm{~cm}$ depth in sandy till, and $50 \mathrm{~cm}$ depth in sandy silty till. Therefore, the characteristics of surface till samples collected at $75 \mathrm{~cm}$ depth or deeper, as presented in the following sections, are not considered to have been significantly influenced by post-depositional processes, but predominantly affected by the nature of the sediment source modified by primary glacial processes.

2.6.2.1 Matrix colour

The colour of till overlying Shield rocks is commonly brown to brownish grey, but 
varies according to the colour of the predominant lithology of the gravel fraction. For example, till can be brownish green if extremely enriched in volcanic belt clasts, and greyish black if enriched in black slates. Over the Paleozoic, regional variations in colour reflect the amount of Precambrian clasts and the underlying Paleozoic bedrock Formations. In areas of thin till which is enriched in carbonate debris, the colour closely reflects the underlying Paleozoic bedrock lithologies. In the Rocky Lake area for example, a pinkish red till is found immediately down-ice from bedrock Formations which contain interbeds of brown to red argillaceous dolomite. East of The Pas Moraine, the till is buff coloured to light red in thin till, reflecting the colour of the local bedrock, predominantly Silurian Formations. Alternatively, till is distinctively greyish white in thick streamlined till, possibly reflecting exotic carbonate debris.

\subsubsection{Texture}

Virtually all till samples collected in the region contain more than $5 \%$ gravel clasts (>2 mm), by weight. Although the samples were not sufficiently large to produce useful statistics for gravel content, broad regional variations can be observed over the study area (Fig. 2.21). Over the Shield, gravel content is elevated in material derived from local greenstone belt rocks as opposed to till overlying granitoids, reflecting the greater erodibility of structurally controlled supracrustal lithologies. Over Paleozoic bedrock, gravel content is higher in the uplands where outcrops are abundant, reflecting the topographic exposure of dolomitic plateaus and their susceptibility to glacial erosion. Till in the Reed Lake Interlobate Moraine is thick but extremely gravel rich. 


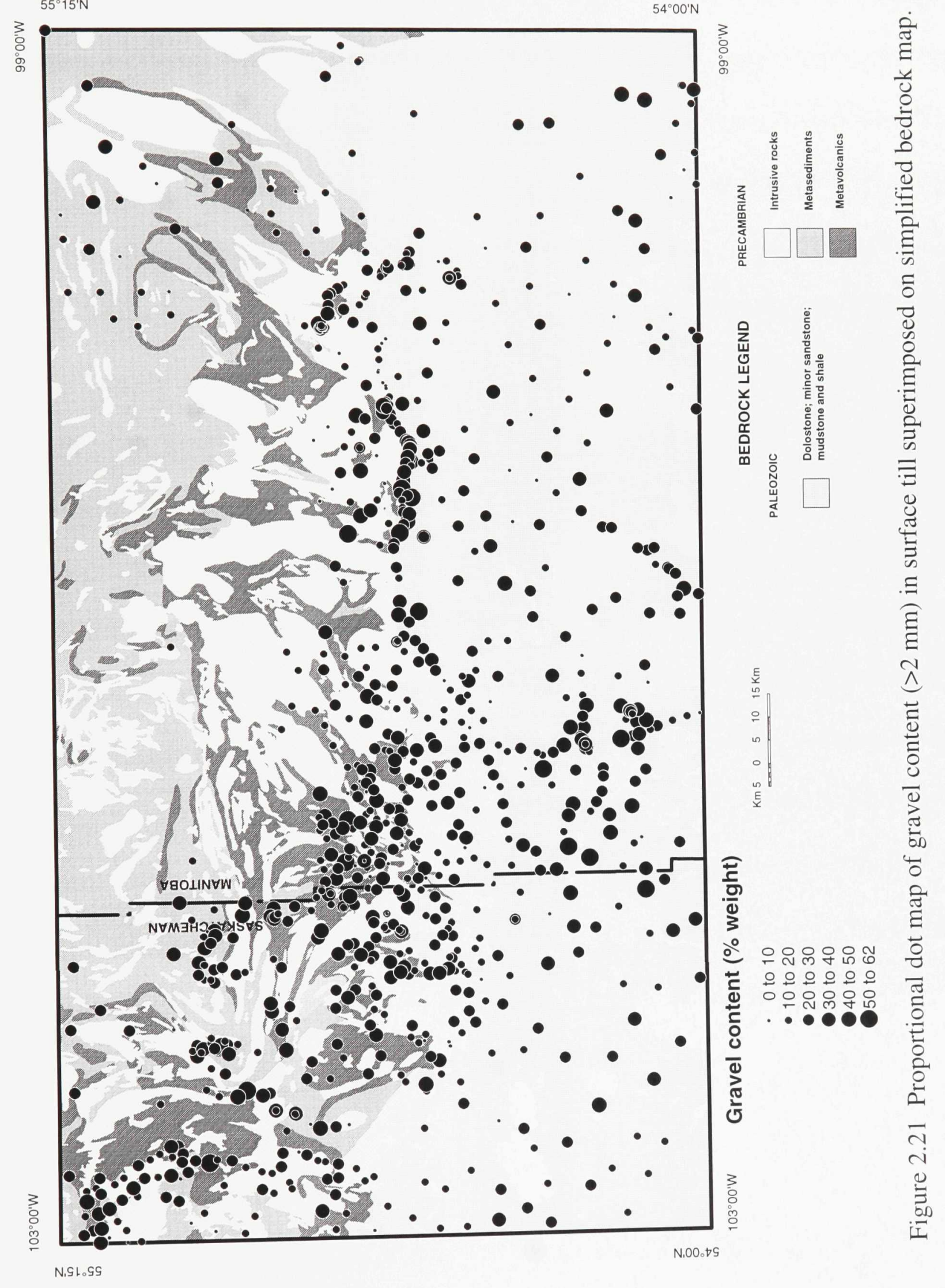


Regional variations in the texture of the till matrix $(<2 \mathrm{~mm})$ are significant amongst the surface samples. Till consists of 9 to $88 \%$ sand, 1 to $78 \%$ silt, and 1 to $61 \%$ clay, but samples in general indicate a cluster with about 55\% sand, $35 \%$ silt and 10\% clay (Fig. 2.22). Till derived from Shield rocks is sandier, containing as much as $88 \%$ sand (Fig. 2.23), and till overlying Paleozoic bedrock is generally siltier (as much as 78\% silt), particularly where it forms a thin cover, but not so much in areas dominated by Keewatin ice flows (Fig. 2.24). Surface till occasionally has a high clay content (up to $61 \%$ ), particularly in areas sampled over the Paleozoic cover west of The Pas Moraine (Fig. 2.25). In excavations, contorted clay lenses and pockets of laminated silt and clay material have been observed in clayey till from this area. In thin deposits, this clayey till is commonly underlain by southwesterly striated surfaces, whereas in thicker deposits, it overlies laminated fine-grained sediments or the regional sandy silty till. The orientation of the underlying fine striae, the texture of this surface till unit, and its stratigraphic position above glaciolacustrine sediments, suggest it was deposited during a late southwesterly readvance of Keewatin ice in Lake Agassiz. Thus, regionally, there is a good relationship between grain size and rock type, and in the case of the clayey till and the Keewatin till over the Paleozoic cover, between grain size and provenance. These relationships will be looked at more closely by examining the pebble lithology of till.

\subsubsection{Pebble lithology}

The regional distribution of rock clasts in till is characterized by two distinct zones. The first zone covers the Precambrian Shield where till shows a high content of Precambrian 


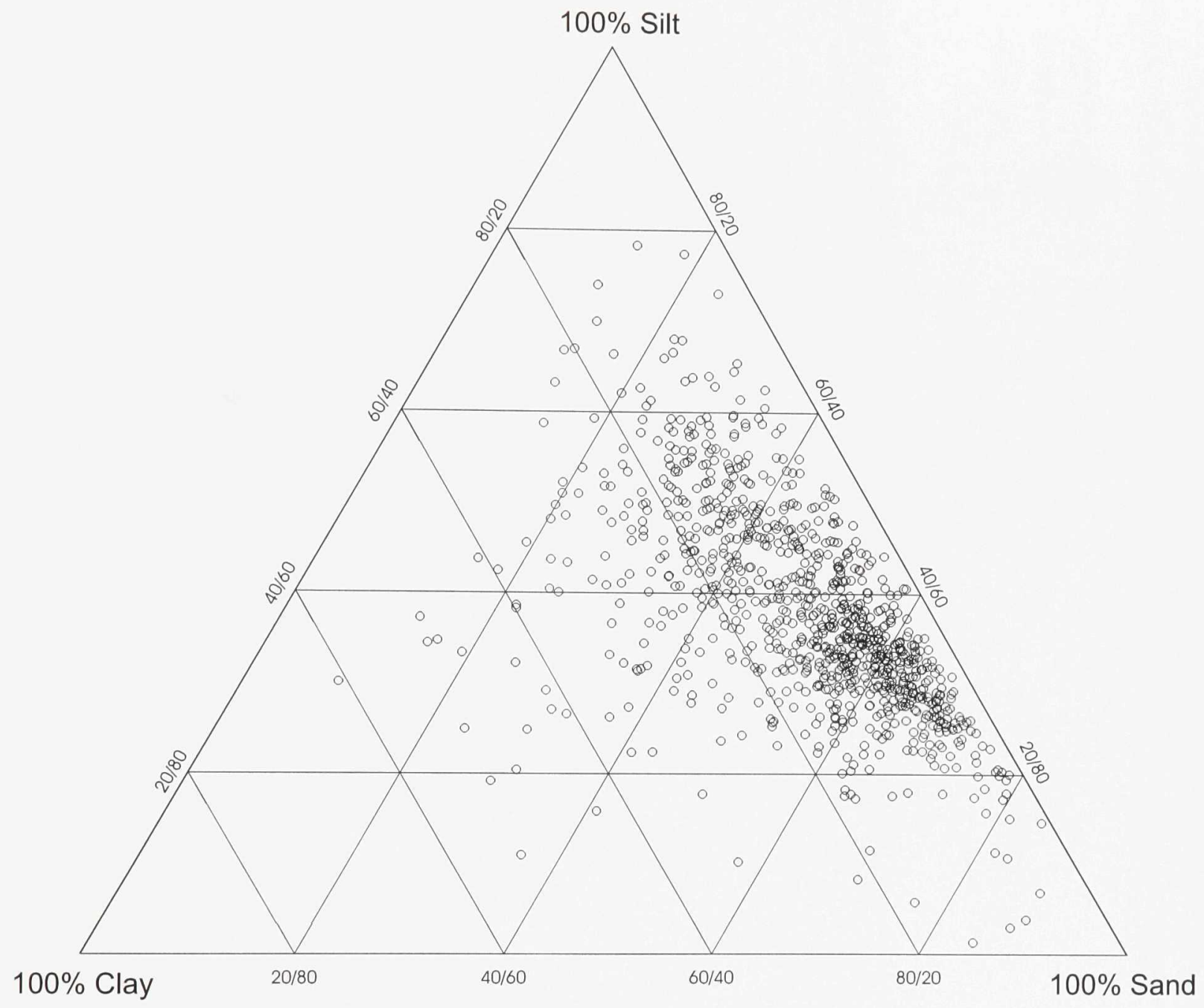

Figure 2.22 Ternary diagram of matrix texture of till across the region $(n=1175)$. 


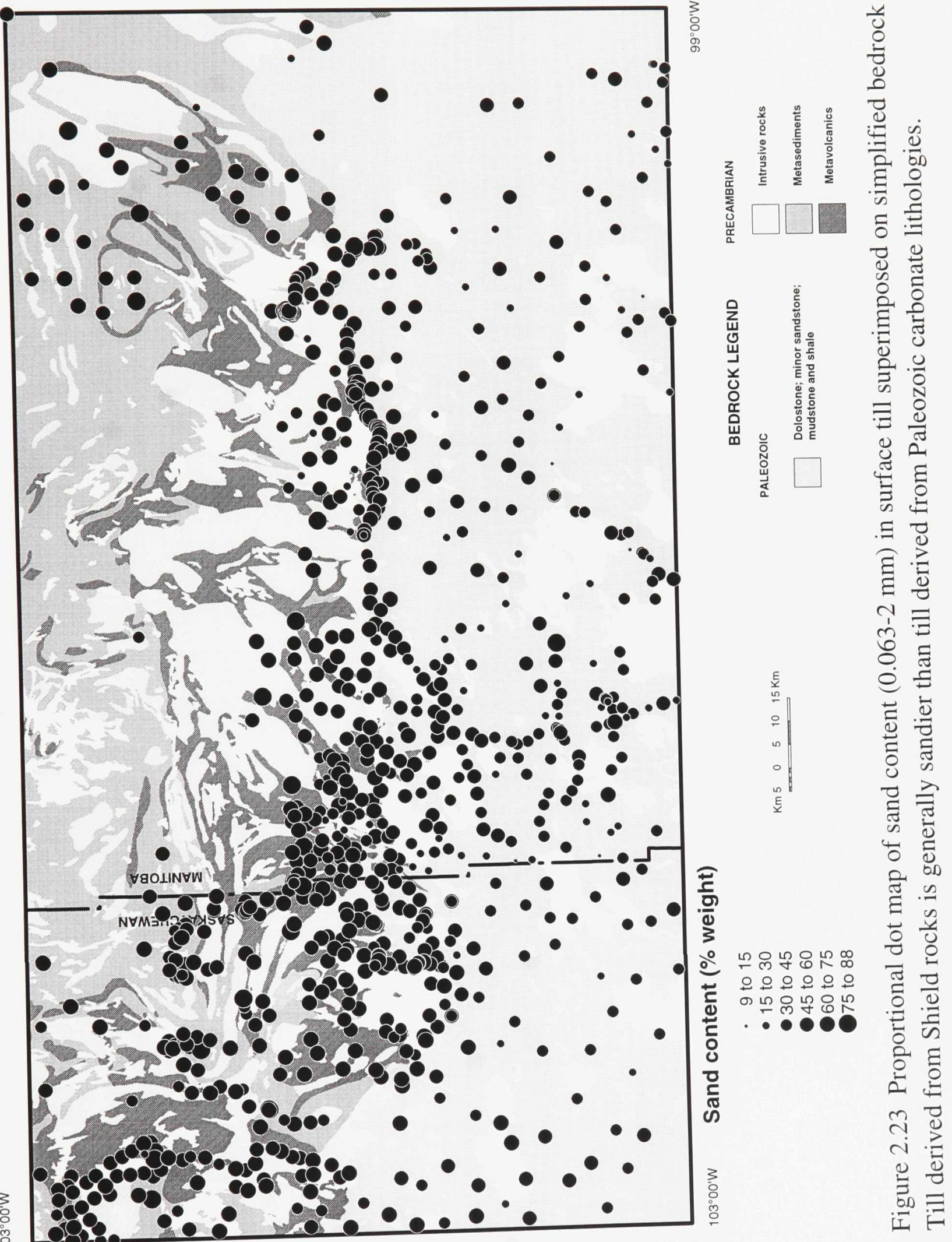




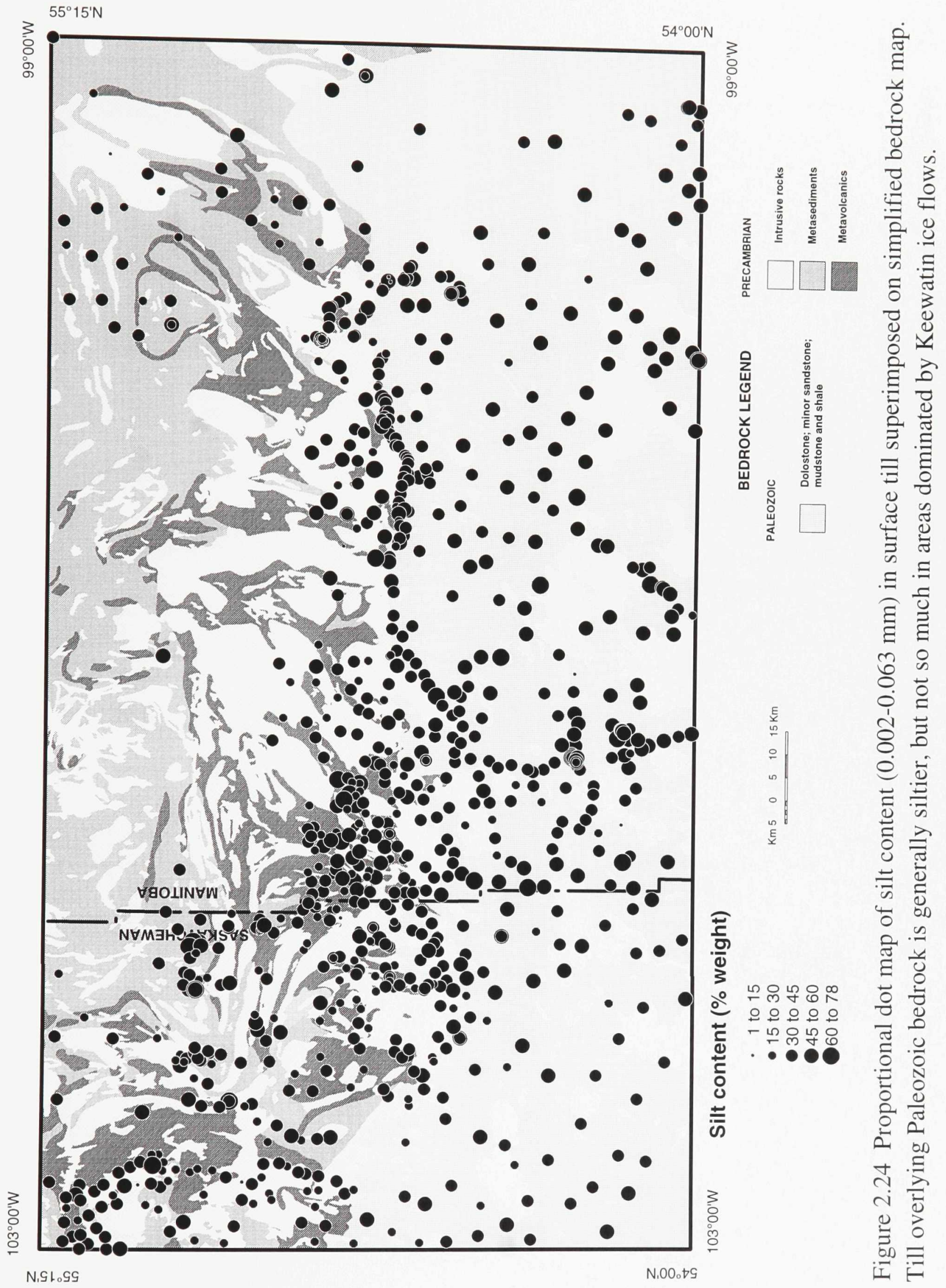




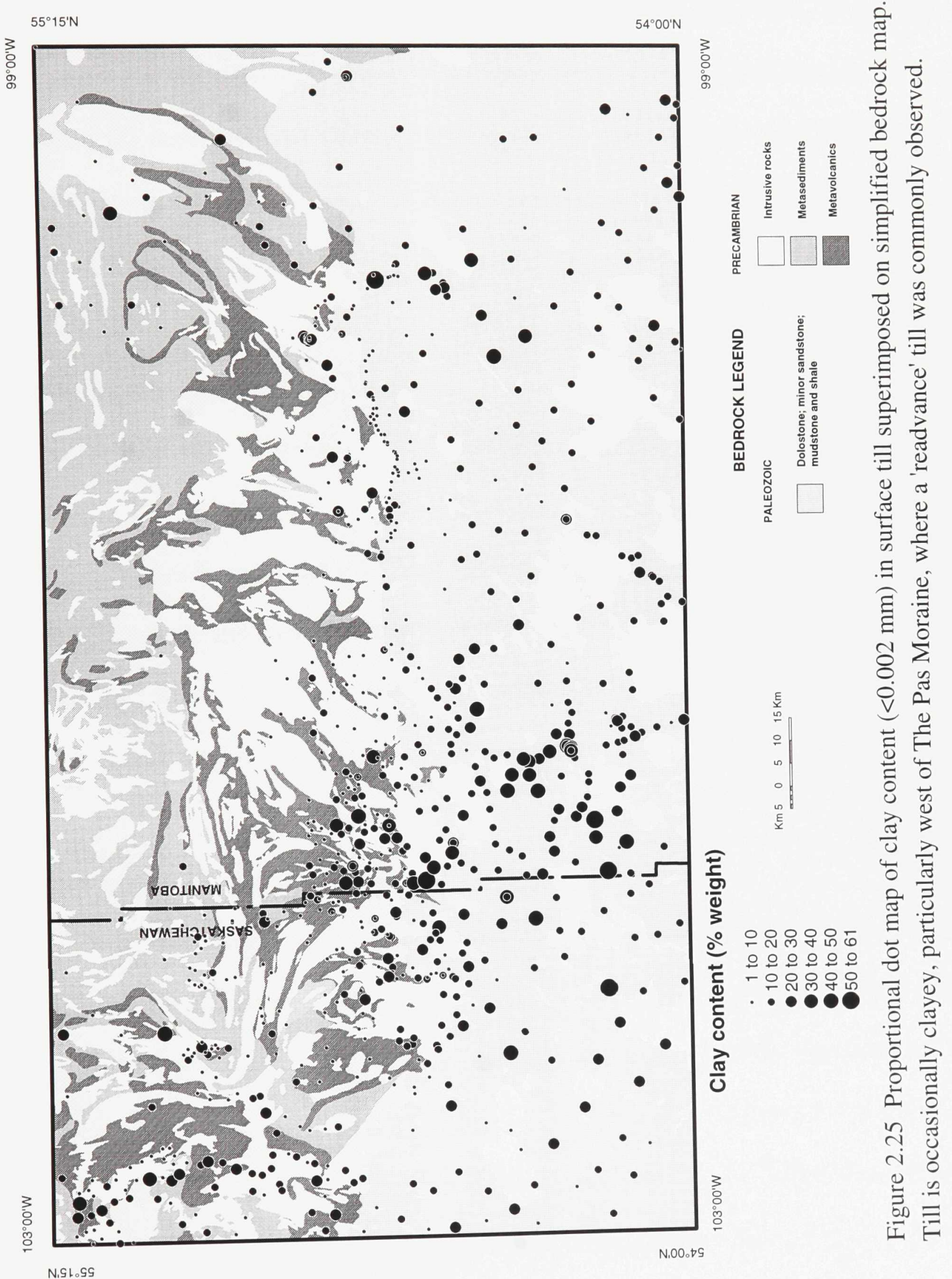


clasts, and, with a few exceptions, an absence of Paleozoic clasts (Fig. 2.26); the second zone covers Paleozoic bedrock where till exhibits a variable content in Precambrian clasts that generally decreases towards the south (Fig. 2.27). The data also show significant variations that cannot be explained solely by the two underlying bedrock types and these are discussed below.

\section{$\underline{\text { Glacial dispersal over Paleozoic bedrock }}$}

Over Paleozoic bedrock, the relative proportion of Shield clasts in till can be used to assess the characteristics of glacial transport (i.e., distance and direction) since the Paleozoic/Precambrian contact is oriented more or less perpendicular to ice flow direction (both for Keewatin and Labradorean ice). In addition, several small sandstone outcrops of the Winnipeg Fm are found along the Shield margin, and these basal sandstones proved to be reliable indicator erratics.

1) Keewatin ice flow

A fairly constant decrease in Precambrian clast content is observed along three transects in the zone dominated by Keewatin ice flow events, from near $100 \%$ at the Paleozoic/Shield contact to a background of less than $25 \%$ at the southern edge of the study area (Fig. 2.28, Transects A-A', B-B', C-C'). The negative exponential function of Krumbein (1937), which reflects glacial transport and abrasion as part of the basal debris load, is therefore capable of describing glacial dispersal in this area. From empirical studies, it has been shown that the shape of the exponential curve basically relates to (1) the velocity 


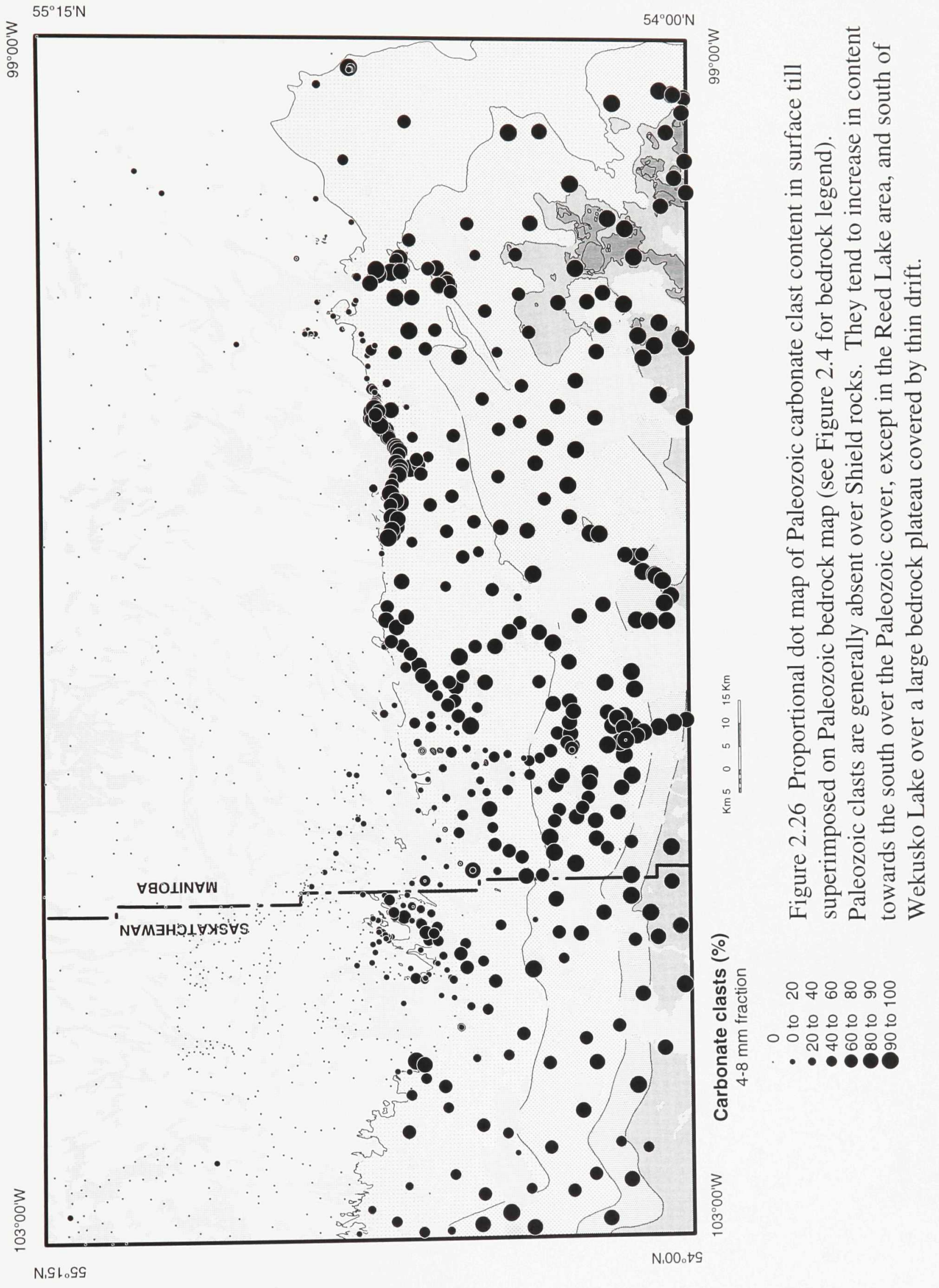




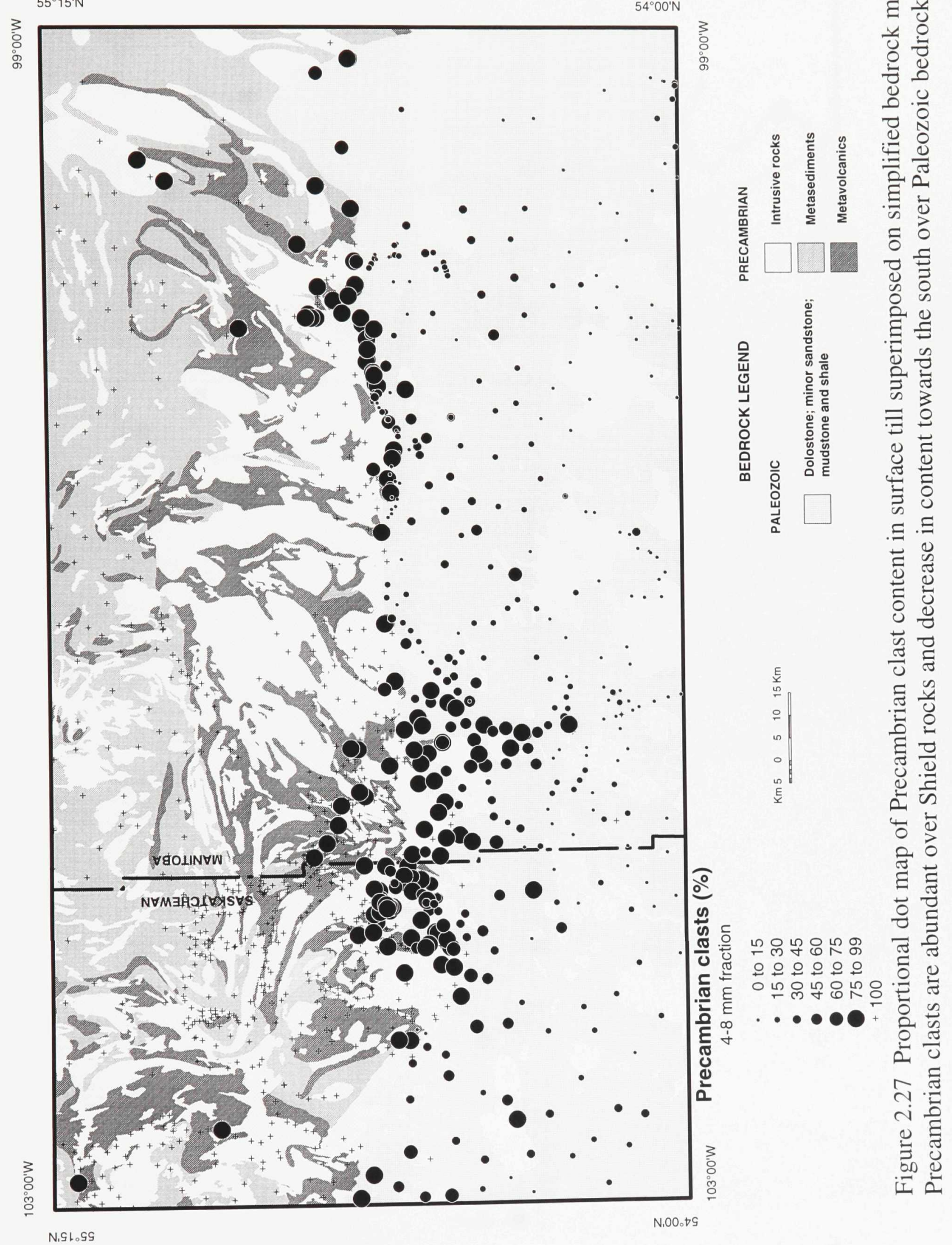



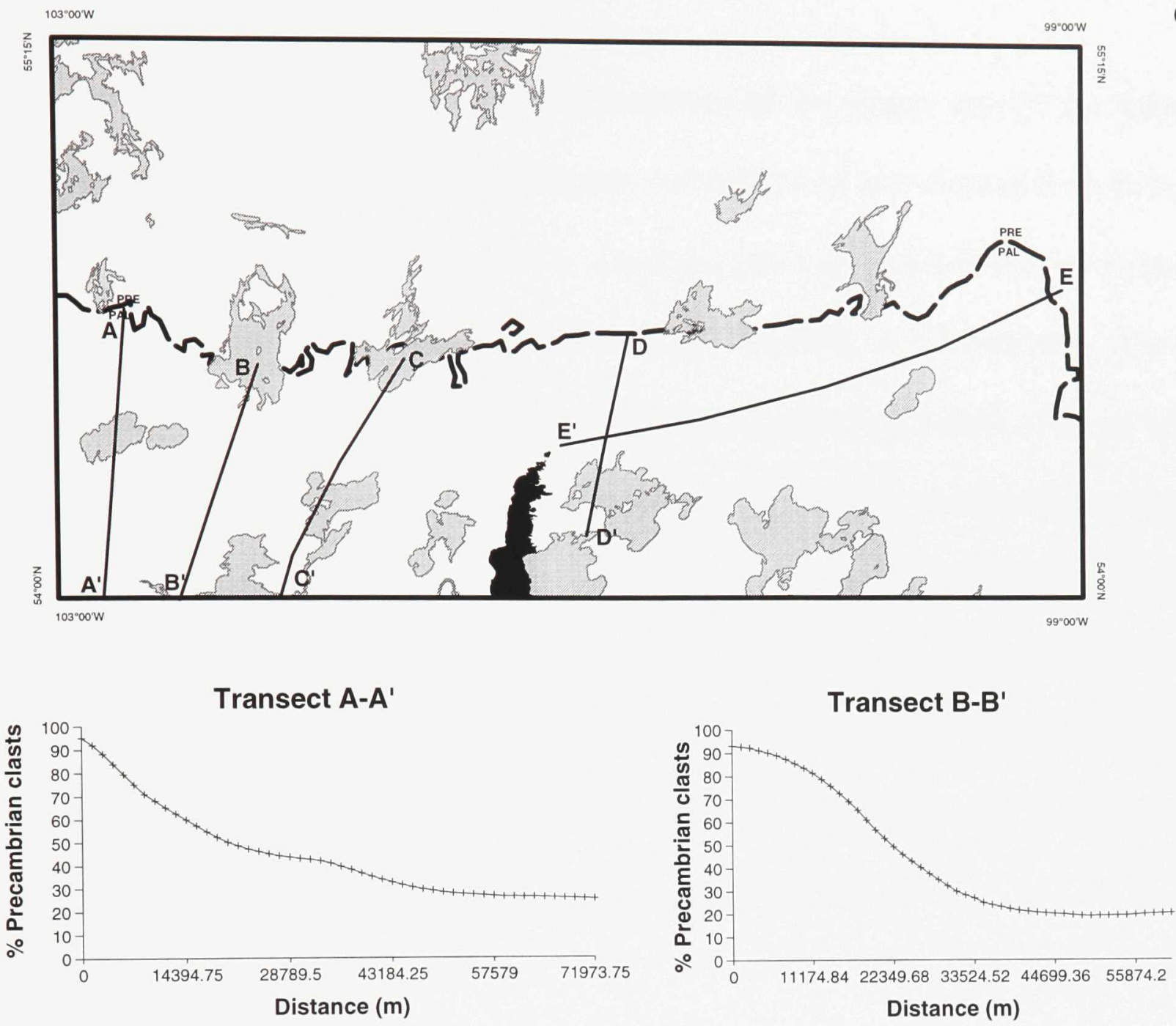

Transect C-C'

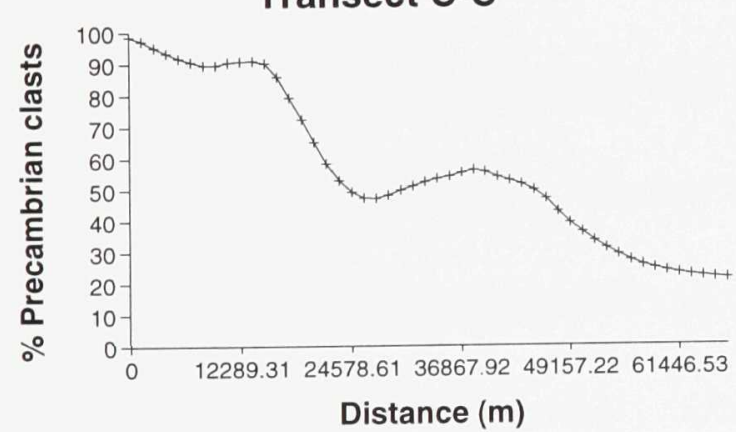

Transect D-D'

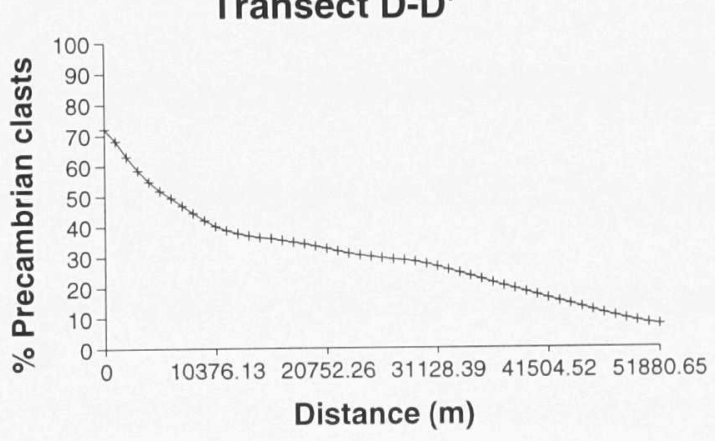

Transect E-E'

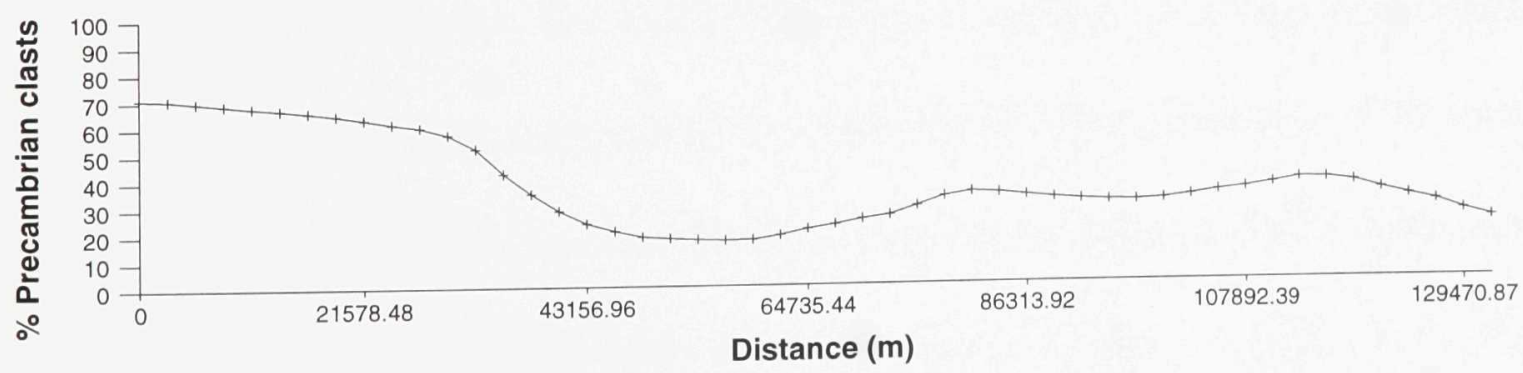

Figure 2.28 Precambrian clast content in till sampled along five transects across the area underlain by Paleozoic bedrock. 
and duration of ice flow, (2) the physical properties of the source, and (3) the balance between re-entrainment of older glacial debris and addition of new detritus from bedrock (e.g., Klassen, 1997). Along transect A-A', the decay curve appears to reflect variations in the thickness of the till bed (or availability of the local bedrock for erosion) rather than ice flow dynamics: the decay is slightly more rapid where the till is thin north of Suggi Lake, whereas it progressively flattens as the till veneer increases to a thick, streamlined blanket south of Suggi Lake. Along transect B-B', there are no major variations in till thickness and outcrops are abundant, hence the slope of the decay curve most closely resembles an exponential decay. The variability in the decay curve along transect C-C' probably reflects the sampling of two distinct surface till units (clayey till and regional sandy silty till), as well as major variations in the till thickness (cf. Figs. 2.16 and 2.17).

\section{2) Labradorean ice flow}

The general southward dispersal of Precambrian debris over Paleozoic bedrock is also observed within the zone predominantly streamlined by Labradorean ice flows (Fig. 2.27). The decay along a transect oriented south-southwesterly shows a quasi linear decrease (Fig. 2.28, Transect D-D'), suggesting re-entrainment of older Keewatin shield-derived tills by Labradorean ice. In addition, the pebble lithology of surface till in this area indicates a significant distal component as expressed by 1) the flat and linear decrease in Precambrian clast content along the main ice flow direction (Fig. 2.28, Transect E-E'), 2) the relative abundance of greywacke erratics from the Omarolluck Fm that outcrops in the Belcher Islands (Prest, 1990), compared to till of Keewatin provenance, and 3) the presence of exotic 
HBL carbonate debris in surface till located directly up-ice, within the area of the radial flow originating near Sipiwesk Lake (Matile and Thorleifson, 1997). Labradorean till also contains a local component as indicated by the abundance of angular carbonate pebbles over large bedrock plateaus covered by relatively thin drift (Fig. 2.26).

3) Reed Lake Interlobate Moraine

The southward increase in carbonate clast content generally characterizes the lithology of till over Paleozoic bedrock. However, in the RLIM, the carbonate content of till is extremely high, ranging from $84 \%$ to $100 \%$ (Fig. 2.26). The hummocks, which are typically composed of stony, sandy and very compact till, alternate with low areas of Precambrian derived sandy till almost devoid of carbonates (Fig. 2.27). The extremely local nature of this stony till unit, typical of hummocky moraine (Salonen, 1988), and its relative immaturity (preponderance of clast over matrix fractions; Dreimanis and Vagners, 1971), suggest the ice responsible for its deposition had different dynamics than the regional ice sheets. The compactness of the till may reflect final overriding of the hummocks by Labradorean ice, as indicated by the presence of west-northwesterly striae (Fig. 2.19).

4) Glacial dispersal of Winnipeg Formation sandstone

The Winnipeg Fm is lithologically distinct from the other Paleozoic Formations and therefore represents a unique indicator lithology for glacial transport studies. Basal sandstone clasts are generally dispersed at short distances from the Shield margin before reaching background at $2 \%$, less than $15 \mathrm{~km}$ from their source outcrops (Fig. 2.29). 


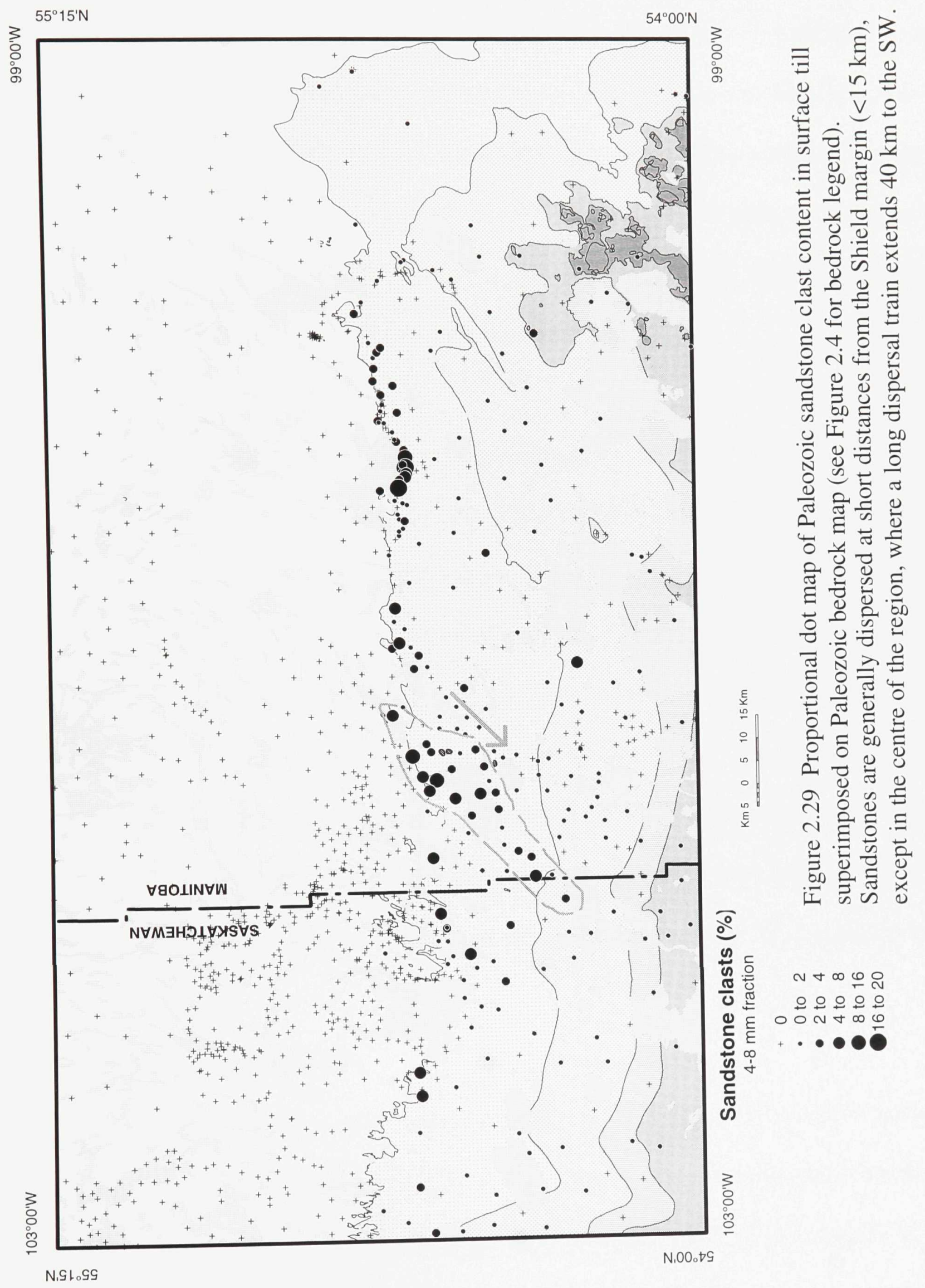


However, south of Athapapuskow Lake, a dispersal train of Paleozoic sandstones extends for $40 \mathrm{~km}$ in a southwesterly direction, parallel to the orientation of the late glacial Keewatin ice flow that readvanced in Lake Agassiz. In the same area, surface till is occasionally clayey and relatively enriched in Precambrian debris. This suggests that the 'readvance' till has a more distal provenance than the regional sandy silty till, perhaps reflecting the low availability of the underlying carbonate bedrock for erosion.

\section{Presence of Paleozoic debris over Precambrian bedrock}

Paleozoic carbonate clasts are occasionally present in sandy Precambrian derived till over the Shield (Fig. 2.26). Most of these clasts are derived from local Paleozoic outliers. Elongated but short $(<3 \mathrm{~km})$ south-southwesterly dispersal trains of carbonate debris occur down-ice from Paleozoic outliers south of Snow Lake, in the Cranberry Portage area, east of Amisk Lake, and in the Mirond Lake area (McMartin et al., 1996). Paleozoic carbonate clasts in surface till are also found in very low contents in a few areas where no Paleozoic outliers are known to outcrop, namely north of Athapapuskow Lake and in the Wekusko Lake area. Reasons for the presence of calcareous till in these areas are discussed later.

\subsubsection{Matrix carbonate content}

Regional variations in total carbonate content of the till matrix generally reflect Paleozoic carbonate clast distribution (Fig. 2.30). Typical values in carbonate content in calcareous samples are 10 to $80 \%$, whereas non-calcareous surface till samples ( $0 \%$ carbonate clasts) contain less than $4 \%$ carbonate determined by AAS (Fig. 2.31), and close 


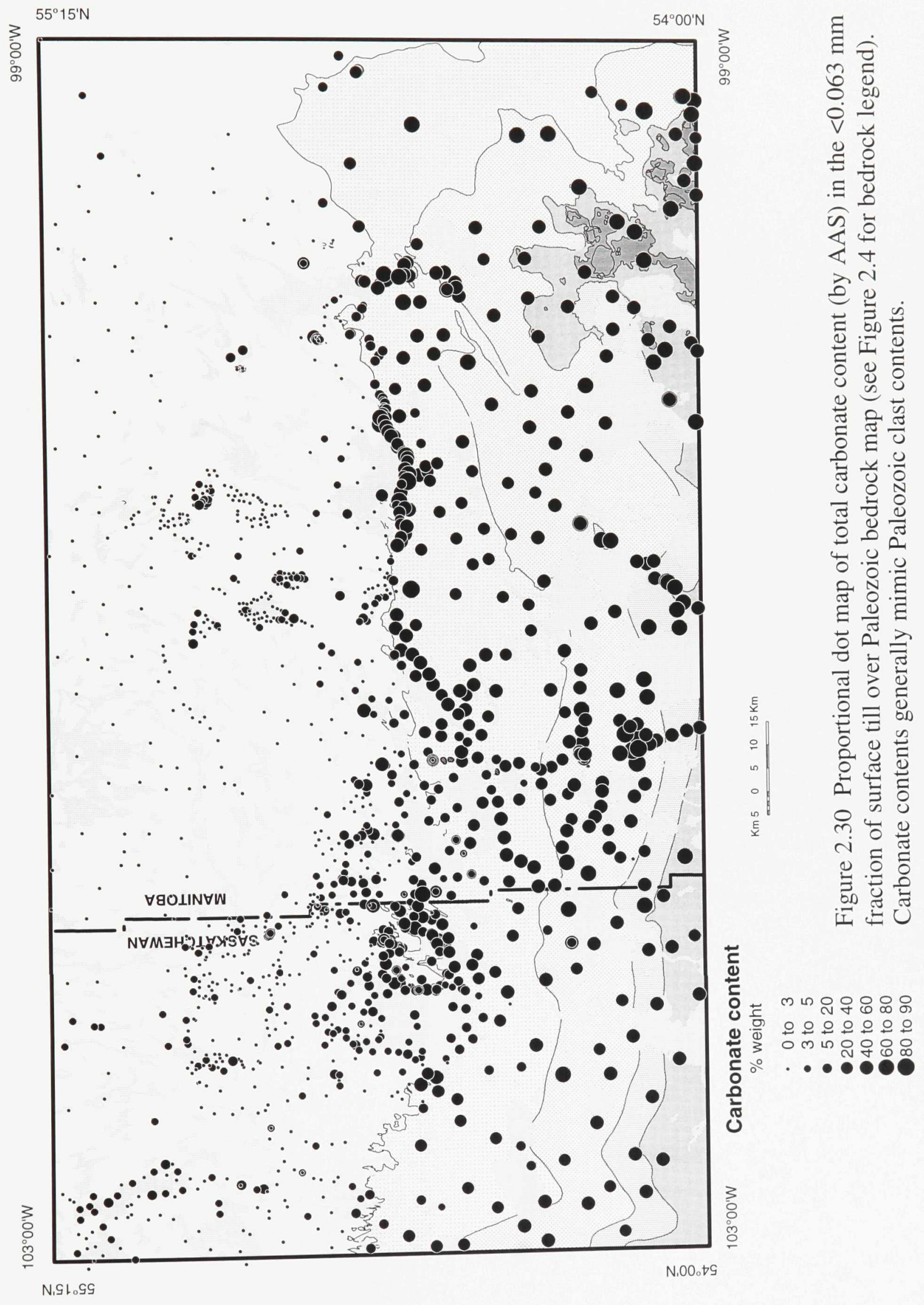




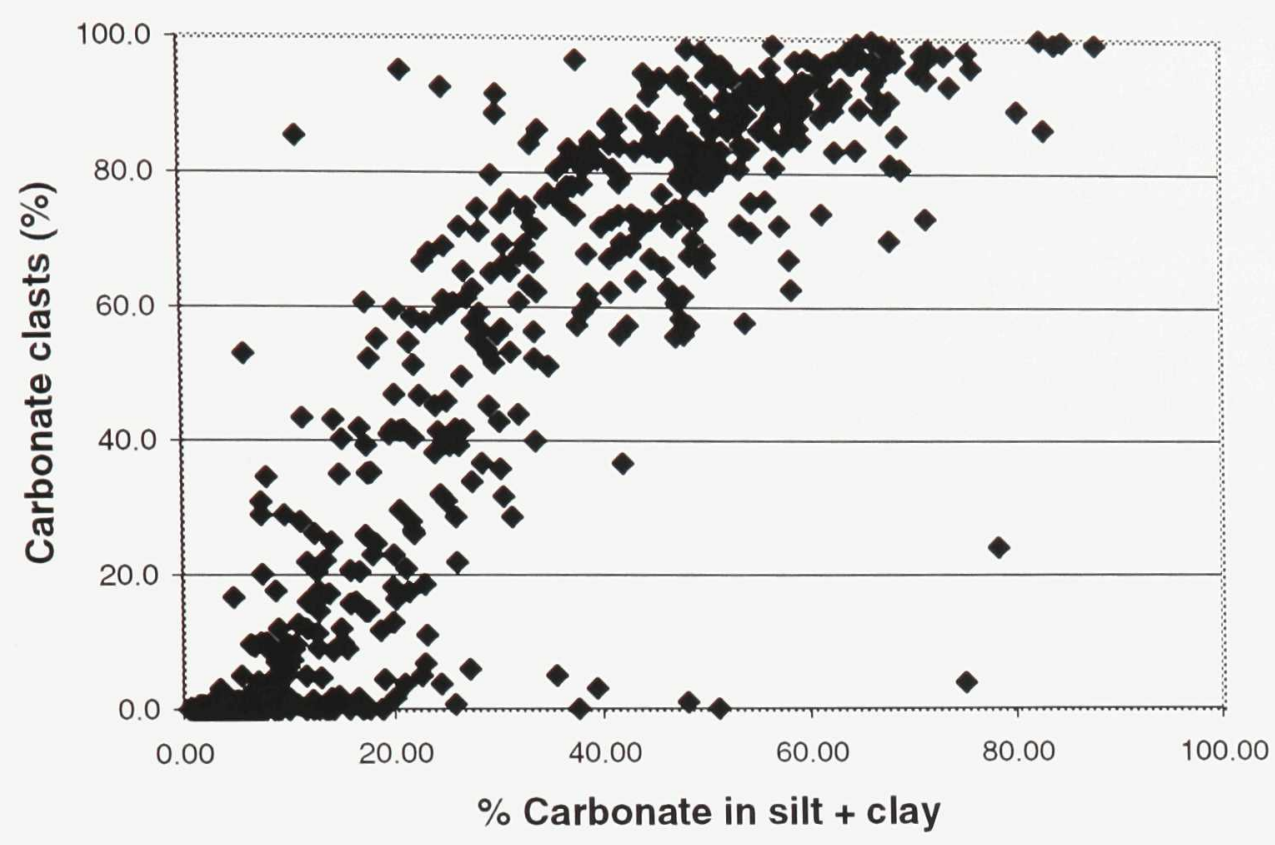

Figure 2.31 Relationship between total carbonate content of the $<0.063 \mathrm{~mm}$ fraction of till analyzed by AAS versus Paleozoic carbonate clast content of the 4-8 mm fraction of till $(n=1158)$. 
to $0 \%$ by Leco. Exceptions include till enriched in clay and low in clast content ('readvance' Keewatin till), which has a much higher carbonate clast content relative to the total carbonate content of the matrix, and till derived from secondary Precambrian carbonate sources.

\section{$\underline{\text { Paleozoic bedrock }}$}

Over Paleozoic bedrock, the carbonate content of till increases with the increasing distance from the Shield margin, reaching concentrations of $90 \%, 60 \mathrm{~km}$ down-ice from the nearest Precambrian outcrop (Fig. 2.30). As with the Paleozoic carbonate clast content, the total carbonate content of the matrix regionally increases towards the south, regardless of till provenance (Keewatin or Labradorean). Because carbonate minerals are known to concentrate in the silt fraction of tills (Dreimanis and Vagners, 1971), the southerly increase in carbonate content may reflect a higher silt content in the matrix of thin till covering bedrock plateaus that are prominent in the southern part of the study area. On the other hand, the mixing of exotic carbonate material transported from the HBL into the study area with local carbonate minerals is suggested by the presence of calcite in till located immediately northeast of the study area (Matile and Thorleifson, 1997).

\section{Precambrian bedrock}

Over Shield lithologies, the carbonate content of till is generally low (Fig. 2.30). However, a number of till samples have low or zero Paleozoic clast content but contain as much as $78 \%$ total carbonate content. These samples regularly have high calcite and low dolomite contents (Fig. 2.32), suggesting the carbonate is derived mainly from secondary 

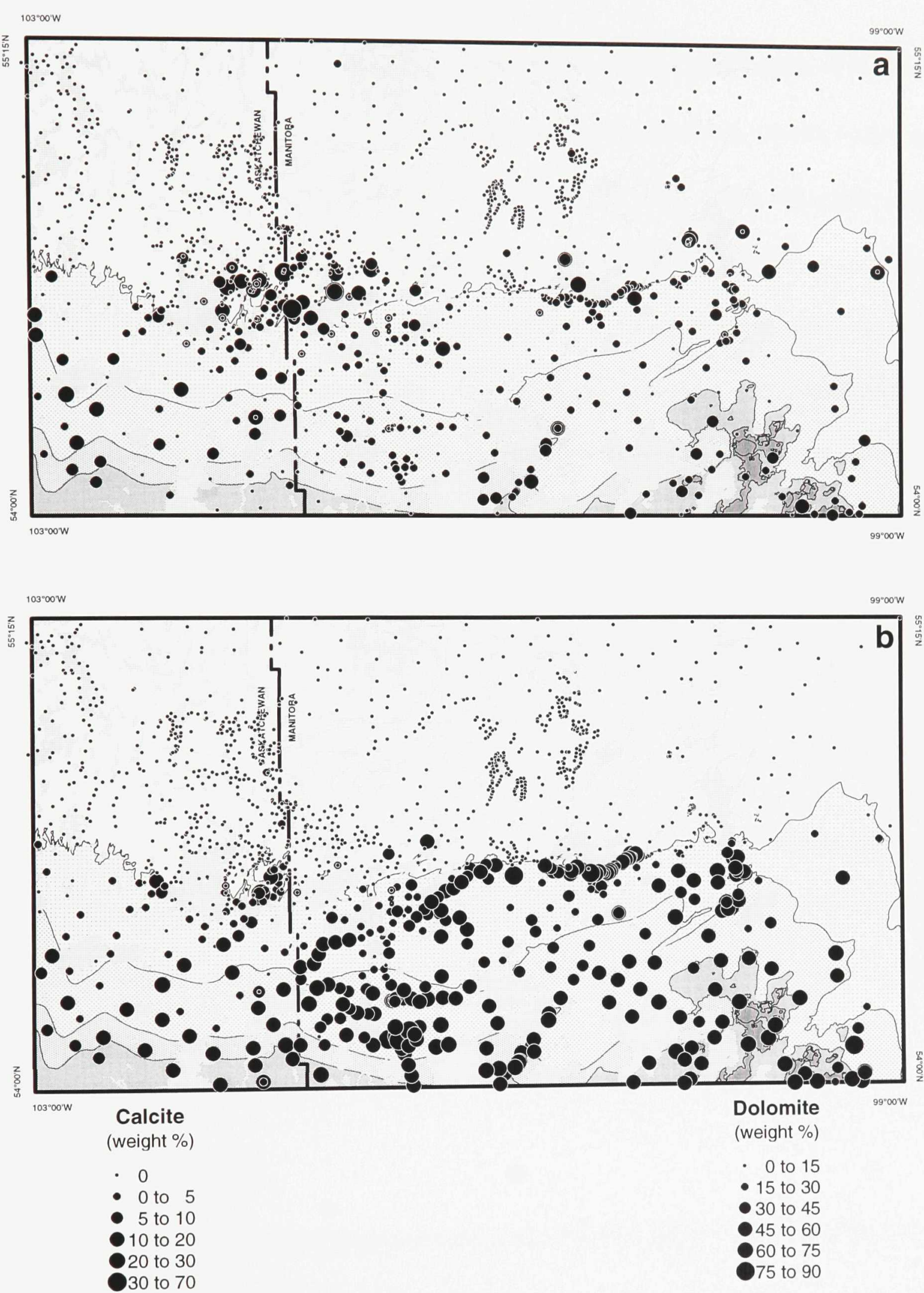

Figure 2.32 Proportional dot maps of (a) calcite, and (b) dolomite in the $<0.063 \mathrm{~mm}$ fraction of surface till. Contents of carbonate minerals have been determined by AAS. Paleozoic bedrock legend is given in Figure 2.4. 
carbonate-rich Precambrian sources. In contrast, at sites immediately north of the Paleozoic margin, the surface till matrix has a low to moderate carbonate content $(<20 \%)$ and a Paleozoic carbonate clast content reaching as much as $10 \%$. This Paleozoic carbonate material is thought to be derived from unknown and/or eroded outliers, or recycled from previously deposited calcareous sediments. Recycling of old carbonate till is supported by the occasional presence of calcareous, silty sandy till preserved under sandy till derived completely from non-carbonate Precambrian sources. At one site, a calcareous till rests on bedrock striated to the west (Henderson and Campbell, 1994), and at several sites, fabric measurements in calcareous till indicate an eastern provenance (Kazsycki et al., 1996; McMartin, 1994c), suggesting these carbonate tills were deposited by Labrador Sector ice.

\subsubsection{Clay mineralogy}

Clay mineralogy of till and Lake Agassiz sediments illustrates the different provenance of the major sediment types in the region. Although rigorous testing to enable absolute identification has not been conducted, the general nature of each clay mineral assemblage is sufficient to characterize each sediment type (Table 2.1).

\section{1) Keewatin Sector till}

Till of Keewatin provenance consistently exhibits a prominent illite peak, and chlorite and/or kaolinite. Quartz, plagioclase, K-feldspar, mica and amphibole are occasionally abundant, whereas expandable mixed layers composed of interstratified illite-smectitechlorite-vermiculite generally occur in trace amounts. Traces of goethite and hematite are 
Table 2.1 Qualitative clay-size mineralogy by XRD.

\begin{tabular}{|c|c|c|c|}
\hline \multirow[b]{2}{*}{ Sediment type } & \multicolumn{3}{|c|}{ Mineralogy } \\
\hline & Abundant & Minor & Trace \\
\hline \multicolumn{4}{|l|}{ 1) Keewatin Sector till } \\
\hline Non-calcareous & $\begin{array}{c}\text { Illite, } \\
\text { Chlorite and/or Kaolinite }\end{array}$ & $\begin{array}{c}\text { Quartz, Plagioclase, } \\
\text { K-feldspar, Mica, } \\
\text { Amphibole }\end{array}$ & $\begin{array}{c}\text { Calcite, } \\
\text { Expandable mixed layer, } \\
\text { Goethite, Hematite, Smectite }\end{array}$ \\
\hline Calcareous & $\begin{array}{l}\text { Illite, } \\
\text { Chlorite and/or Kaolinite, } \\
\text { Dolomite }\end{array}$ & $\begin{array}{c}\text { Quartz, Plagioclase, } \\
\text { K-feldspar, Mica, Smectite, } \\
\text { Amphibole, Calcite }\end{array}$ & $\begin{array}{c}\text { Expandable mixed layer, } \\
\text { Goethite, Hematite }\end{array}$ \\
\hline 2) Labrador Sector till & Dolomite, Calcite & $\begin{array}{l}\text { Expandable mixed layer, } \\
\text { Chlorite and/or Kaolinite }\end{array}$ & $\begin{array}{l}\text { Illite, Smectite, } \\
\text { K-feldpar, Plagioclase, } \\
\text { Quartz, Vermiculite }\end{array}$ \\
\hline 3) Lake Agassiz clay & $\begin{array}{l}\text { Expandable mixed layer, } \\
\qquad \text { Smectite }\end{array}$ & $\begin{array}{c}\text { Dolomite (Paleozoic), } \\
\text { Illite (Shield) }\end{array}$ & Calcite \\
\hline
\end{tabular}


also found in Keewatin till. In addition to these minerals, calcareous till of Keewatin provenance over the Paleozoic have abundant dolomite. Smectite is commonly but not regularly present, particularly in clayey till overlying glaciolacustrine sediments. The clay mineralogy of till in the Reed Lake Interlobate Moraine is similar to that of Keewatin till over Paleozoic bedrock, i.e., it contains abundant dolomite, illite and chlorite, suggesting it was deposited by Keewatin ice encroached upon by Labradorean ice. Over Precambrian bedrock, when carbonate minerals do occur, calcite is generally abundant relative to dolomite which reflects the presence of secondary Precambrian carbonate sources.

\section{2) Labrador Sector till}

Till of Labradorean provenance is characterized by an abundance of carbonate minerals (dolomite and calcite), and the rarity of illite and smectite. Illite is slightly more abundant in till located immediately south of the Shield margin, indicating the recycling of previously deposited shield-derived Keewatin till. Mixed layers of interstratified clay species, interpreted as illite-smectite-chlorite occur in minor to trace amounts. Minor chlorite, and/or kaolinite, and traces of K-feldspar, plagioclase and vermiculite are found.

\section{3) Lake Agassiz clay}

Lake Agassiz clay is composed primarily of expandable mixed layer smectitechlorite-illite with a high smectite content. The source for the smectitic clays is likely from a major inflow to the west (Saskatchewan River), draining Cretaceous terrain in Saskatchewan and Alberta. Dolomite is absent from glaciolacustrine clays over the Shield 
and occurs in minor amounts over the Paleozoic. Lake Agassiz clay deposited below the clayey 'readvance' till has more illite and dolomite, indicating a greater contribution from retreating ice, both Keewatin and Labradorean, whereas clay deposited above the till is mainly derived from extra-basinal sources (smectite), when the ice margin had retreated out of the study area.

\subsubsection{Clay geochemistry}

It is well known that postglacial weathering can have a radical effect on the geochemistry of the drift in the zone of oxidation above the groundwater table, commonly to a depth of a few metres (e.g., Peuraniemi, 1984; Shilts and Kettles, 1990). During postglacial weathering and subsequent soil formation, clastically dispersed labile minerals such as sulphides and carbonates are decomposed in the oxidation zone. Some of the metals are almost immediately precipitated, depending on the element and the local geochemical environment, while others get caught in clay-sized phyllosilicates and secondary oxides/hydroxides or are completely leached out of the soil profile through the groundwater system (e.g., Shilts, 1984). In the Flin Flon region, the material sampled at $1 \mathrm{~m}$ depth lies below the effects of pedogenesis and is only slightly oxidized. It generally reflects primary glacial erosion and transport of underlying bedrock (Kaszycki et al., 1996; McMartin et al., 1996).

Till geochemistry data and distribution maps for the Flin Flon region have been published by McMartin et al. (1996). A brief summary is presented here and discussed 
further in Chapters IV and V. Results show that 1) till derived from felsic intrusive lithologies is depleted in most trace metals, particularly in $\mathrm{Zn}, \mathrm{Cu}$, and $\mathrm{Ni}$, with respect to other shield-derived till, 2) till derived from felsic volcanics is enriched in $\mathrm{Zn}$ and $\mathrm{Cu}, 3$ ) till derived from mafic to intermediate volcanics is enriched in $\mathrm{Cu}, \mathrm{Ni}, \mathrm{Cr}$ and $\mathrm{Co}$, and 4) till overlying Paleozoic bedrock has high $\mathrm{Ca}, \mathrm{Mg}$ and $\mathrm{Sr}$ concentrations, but low trace metal concentrations. Therefore, regional geochemical variations reflect the relative proportion of intrusive/greenstone/carbonate rocks glacially eroded and transported over the various lithological domains. Subtle regional geochemical trends related to till provenance are also reflected in surface till sampled over the Paleozoic. Till deposited by Keewatin ice west of The Pas Moraine is slightly enriched in $\mathrm{Ag}, \mathrm{Co}, \mathrm{Cr}, \mathrm{Fe}, \mathrm{K}, \mathrm{La}, \mathrm{Sc}, \mathrm{V}$ and $\mathrm{Zn}$, and relatively depleted in $\mathrm{Ca}$ and $\mathrm{Mg}$, compared to till deposited largely by Labradorean ice, reflecting primary enrichment related to glacial dispersal of Precambrian debris over Paleozoic bedrock. As an example, the distribution of $\mathrm{Cr}$ and $\mathrm{Mg}$ in till are shown in Figure 2.33.

\subsubsection{Summary of surface till composition and distribution}

Two major factors control the texture and composition of till in the area: (1) the nature of the nearby or subjacent rock types, and (2) characteristics of glacial transport or provenance (Keewatin versus Labradorean). The effects of surface weathering and the amount of glaciolacustrine reworking are minimized in the upper C-horizon material where most of the surficial till samples were collected. Five distinct surface till units have been recognized in the study area: 


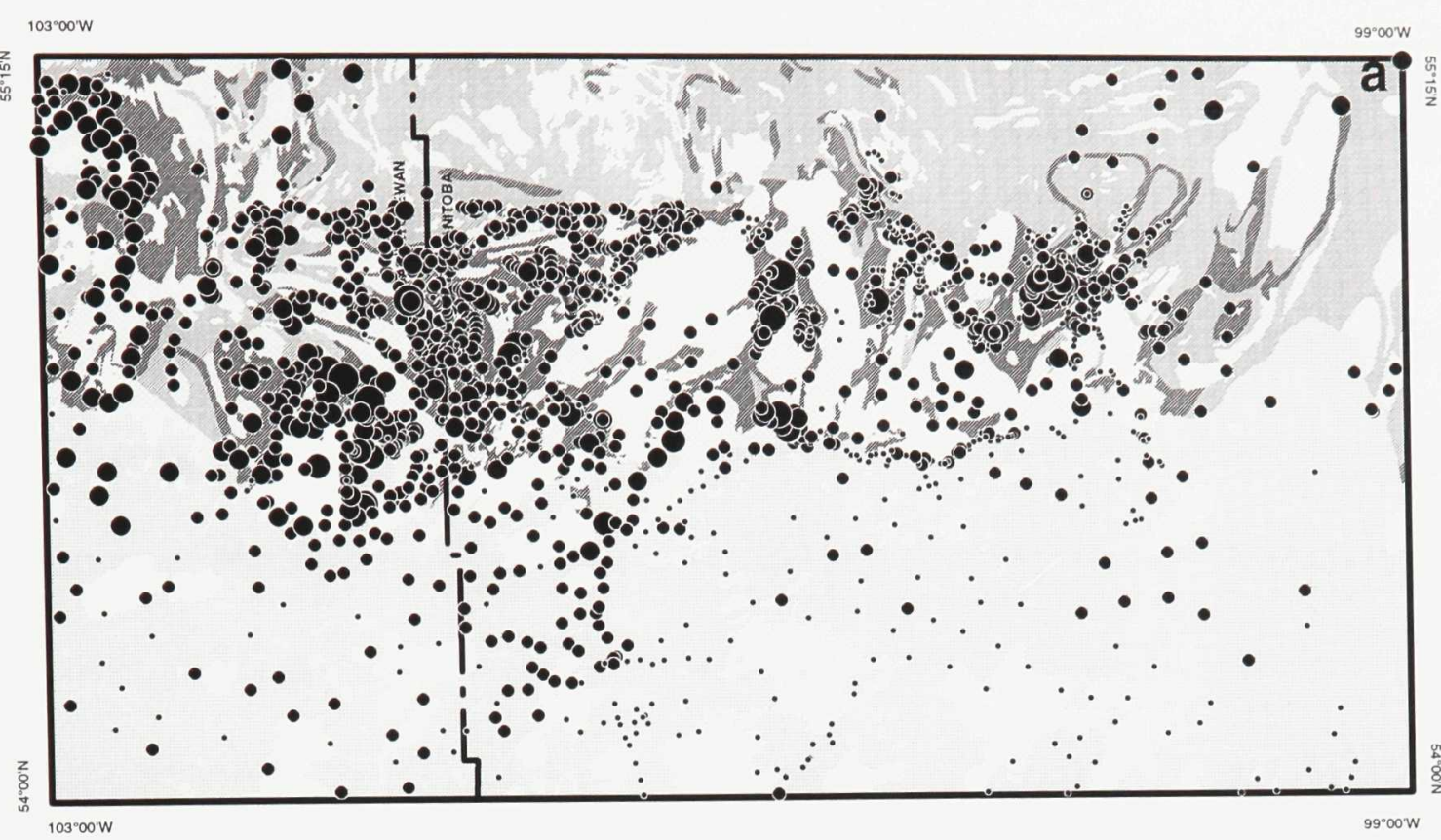

83

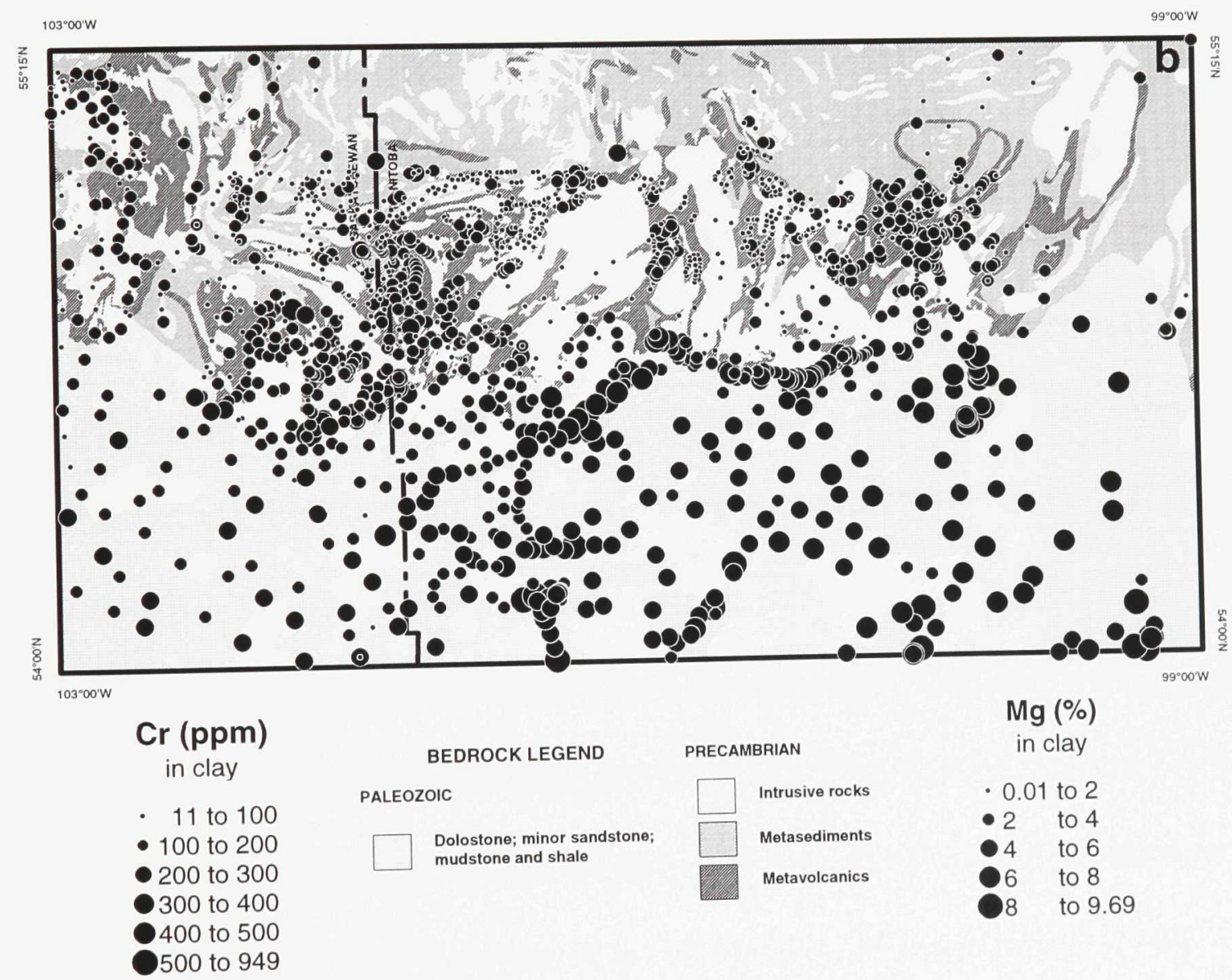

Figure 2.33 Proportional dot maps of (a) chromium, and (b) magnesium in the clay fraction of surface till across the study area, over simplified bedrock map. $\mathrm{Cr}$ is slightly enriched in till west of The Pas Moraine whereas Mg is depleted in the same area, reflecting regional geochemical trends related to till provenance. 
1) Over Shield rocks, the most pervasive unit consists of a locally derived till overlying bedrock striated by the predominant ice flow toward the south-southwest from a Keewatin Sector dispersal centre. The till has a sandy matrix, a relatively high gravel content, particularly over greenstone belt rocks, is non calcareous to occasionally calcareous, contains a high amount of common rock forming minerals in the clay fraction (illite, quartz, feldspar, chlorite, etc.), and is geochemically closely related to nearby bedrock lithologies. This unit forms a discontinuous and thin cover that thickens on the lee-side of bedrock knobs. It is likely that some component of this locally derived till is a remnant of till deposited during earlier events, including westerly flows of Labradorean provenance.

2) Over the Paleozoic cover, the composition and texture of the Keewatin shield-derived till grades into a weakly calcareous, sandy silty till near the Precambrian-Paleozoic contact to a silty highly calcareous till in the southern part of the study area as the Shield component becomes progressively diluted by the continuous incorporation of Paleozoic debris. This unit corresponds to the "Wanless till" of Nielsen and Groom (1987), although these authors did not differentiate this regional till from the clayey till deposited during a readvance in Lake Agassiz. In areas of thin till, the elevated gravel content corresponds to a high carbonate clast content, reflecting the high susceptibility of Paleozoic bedrock to glacial erosion over topographic highs. The reddish colour of the till in these areas is closely related to the presence of red beds of argillaceous dolomites. Clay mineralogy is similar to Keewatin shield-derived till with an abundance of illite and chlorite, but dolomite is also present. Regional variations in colour, clast composition, gravel content and clay geochemistry of till 
reflect the distance of transport down-ice from the Shield margin and the nature of the nearby Paleozoic bedrock Formations.

3) A younger till was recognized at numerous sites within the zone influenced by a late southwesterly flow of Keewatin ice on either side of the Shield margin. The composition and texture of this surface unit vary from weakly to moderately calcareous, clast-poor, sandy clayey till where ice has incorporated fine textured glaciolacustrine sediments, to a non to weakly calcareous, sandy silty till rich in Precambrian debris, where it overlies a previously deposited till or bedrock. Clay mineralogy commonly reflects the incorporation of exotic smectitic clays deposited in Lake Agassiz. This till is interpreted to have been deposited during a late southwesterly readvance of Keewatin ice in Lake Agassiz that spanned most of the Shield and the area west of The Pas Moraine. The composition of this till indicates that the depositing ice was less erosive of the local carbonate bedrock, perhaps because of compositional masking by older sediments.

4) East of The Pas Moraine, over Paleozoic bedrock, the surface till consists of a moderately to strongly calcareous, sandy silty till, variably enriched in Paleozoic carbonate pebbles, and relatively clast-poor. Nielsen and Groom (1987) named this unit the "Clearwater till". The clay fraction is characterized by an abundance of dolomite and calcite, with minor amounts of mixed layer clays, illite and chlorite, and by subdued trace metal concentrations. The till surface is commonly streamlined to the west and southwest, and drumlins form a radial pattern that originates $250 \mathrm{~km}$ up-ice from The Pas Moraine in the Sipiwesk Lake area. The 
recycling of older Keewatin shield-derived till, the marked discontinuities in regional ice flow trends, the radial pattern of ice flow defined by streamlined landforms, and the presence of far-travelled $(>50 \mathrm{~km}$ ) debris suggest a more distal provenance for Labradorean till than Keewatin till. However, in areas of high bedrock plateaus in the south, the association of thin till with high gravel, high carbonate and high silt contents reflects a local provenance. Likely mixing between local and exotic debris occurred within areas glaciated by Labradorean ice. A reddish pink, clast-rich, sandy silty till is occasionally found in this zone and is not interpreted as a separate till unit (e.g., "Arran till"), but as a locally derived till reworked or deposited by an ice lobe of Labradorean provenance.

5) A very cobbly, highly calcareous compact till is present in hummocks within a large eastwest trending zone south of Reed Lake, redefined here as the Reed Lake Interlobate Moraine. Striations underlying the till in this zone indicate a predominant flow towards the southwest. Furthermore, the clay fraction is similar to that of Keewatin till in terms of mineralogy, and is slightly enriched in trace metals (e.g., $\mathrm{Co}, \mathrm{Cu}, \mathrm{Fe}, \mathrm{Mn}, \mathrm{Pb}, \mathrm{Sc}$ ), suggesting the till was deposited predominantly by Keewatin ice encroached upon by Labradorean ice in an interlobate position. The RLIM may have been locally overridden by Labradorean ice as indicated by the presence of west-northwesterly striae and the compactness of the till in the hummocks.

\subsubsection{Stratigraphy}

The landscape of the Flin Flon region is largely sediment poor, particularly over the 
Shield. Precambrian bedrock lithologies are relatively resistant to glacial erosion, and, therefore, production of glacial debris was minimized. Over Paleozoic terrain, little stratigraphic information is available except that related to deglacial events. Consequently, thin drift overlying bedrock observed in sections along roadcuts, borrow pits, and excavations appears to be a deposit of the last glaciation. Four sections with multiple thin till units were observed and are discussed briefly (Fig. 1.2).

\subsubsection{Wanless section}

In the Wanless area, two backhoe excavations exposed multiple thin till units separated by glaciolacustrine sediments (Fig. 2.34). A very thin, fissile and compact, orange brown, calcareous ( $42 \%$ ), silty sandy till overlies bedrock striated by a westerly flow at the base of the sequence (unit D). A reddish brown calcareous silty and pebbly till similar to unit D outcrops at several sites in the Cormorant Lake area. At one site near the town of Cormorant, this unit lies directly on bedrock striated westerly and underlies the regional buff coloured, calcareous, sandy silty till. Unit D, therefore, appears to be a basal till deposited by an early westerly flow of Labradorean ice of unknown age. A thin, fissile and compact, pinkish brown, strongly calcareous (53\%), sandy silty till with a strong fabric $\left(199^{\circ}\right)$ overlies the lower till unit. At site 93MOB0064 (Fig. 2.34), these two units are separated by a thin layer of pinkish brown, massive silts. Unit $\mathrm{C}$ is widespread west of The Pas Moraine, and becomes pinkish brown only south of the northern shores of Rocky Lake and Namew Lake. Pebble and matrix composition have shown that unit $\mathrm{C}$ is a locally derived basal till of Keewatin provenance. Above unit $\mathrm{C}$, is a complex glaciolacustrine unit composed of 


\section{Wanless Section \\ Site 93MOB0064}

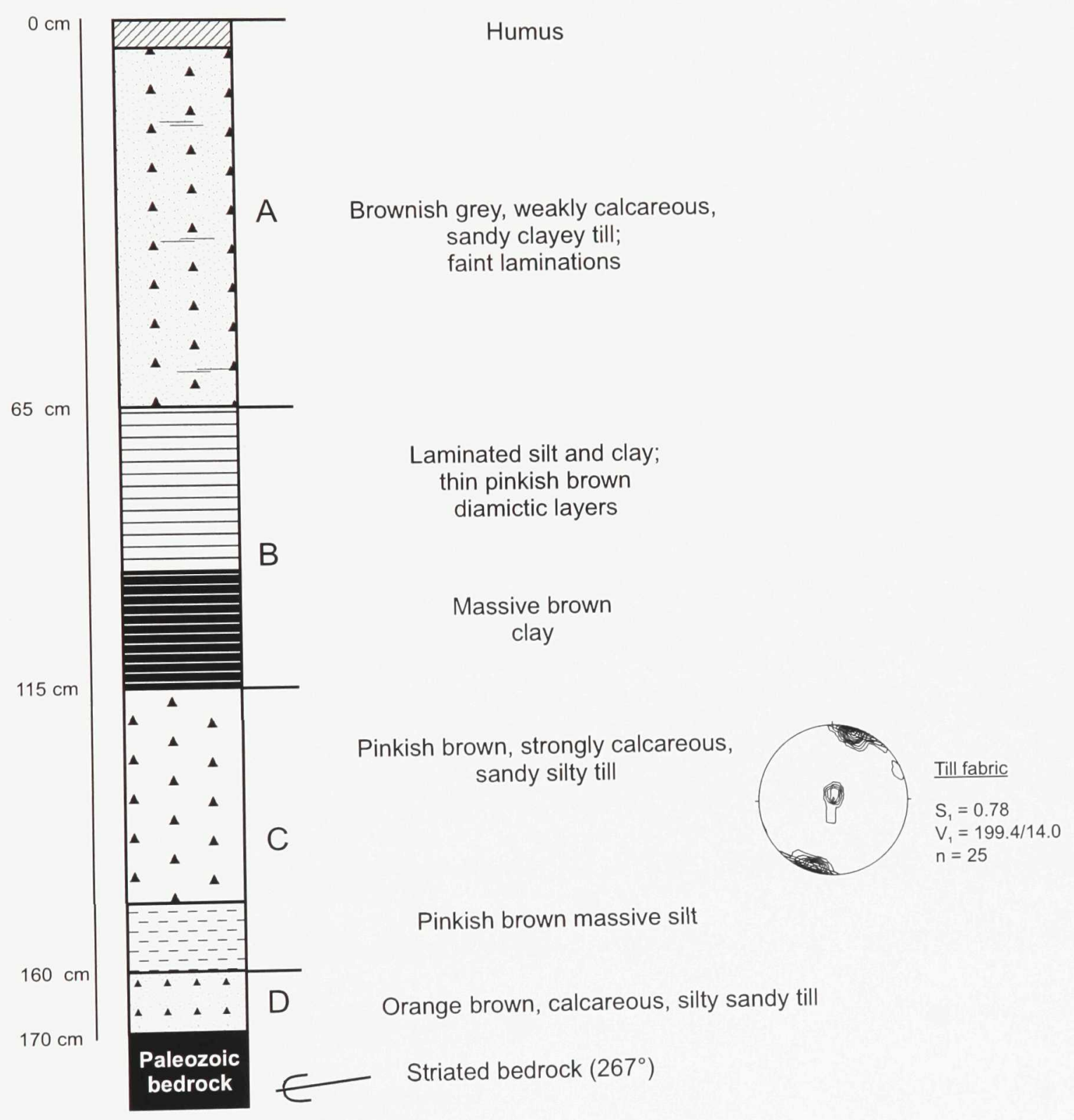

Figure 2.34 Stratigraphy of the Wanless Section. 
interbedded laminated sediments, with thin pinkish brown diamictic layers, and massive brown clay (unit B). A brownish grey, weakly calcareous (17\%), sandy clayey till with irregular laminations and a weak fabric is found at the surface (unit A), above the laminated sediments. The composition and texture of Unit A reflects the incorporation of glaciolacustrine sediments and its deposition during the southwestward readvance into Lake Agassiz.

\subsubsection{Cormorant Lake section}

Near the town of Cormorant, a $2.1 \mathrm{~m}$ deep exposure in a borrow pit exposed two till units separated by a sharp contact and differentiated on the basis of colour, texture, clast composition, carbonate content, and clay geochemistry (McMartin et al., 1996) (Fig. 2.35).

The lower till (unit B) is greyish brown, very compact, moderately to strongly calcareous (37\% to 51\%), silty sandy, and moderately enriched in Precambrian clasts (21\%). The upper till (unit A) is sandy silty, strongly calcareous (53\% to 63\%), greyish pink, fissile, and contains fewer Precambrian clasts $(11 \%)$. The upper till is also slightly depleted in most trace metals compared to the lower till. Cross-cutting striae found at the base of the pit over a bedrock high indicate ice flow towards $248^{\circ}$ post-dated by a slightly more westerly flow $\left(266^{\circ}\right)$. On the basis of these differences in ice flow direction and till composition, the lower till is interpreted to have been deposited by the main advance of Labradorean ice, and the upper till by the later more westerly shift of Labradorean ice prior to deglaciation. It is possible that the Arran till, found extensively south of the study area, correlates with this upper till. Elsewhere in the study area, the Arran till could not be differentiated from the 


\section{Cormorant Lake Section \\ Site 94MOB0140}

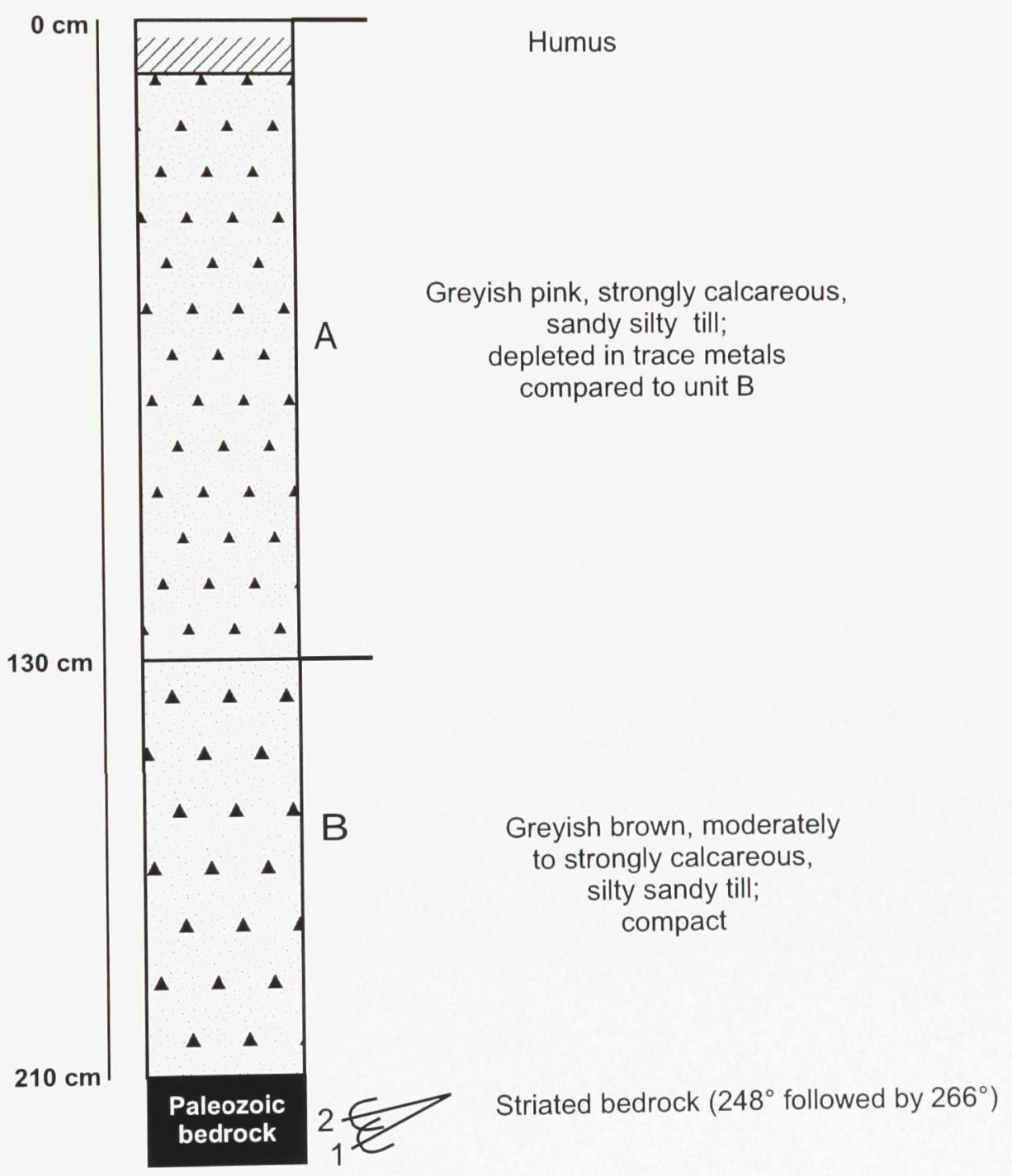

Figure 2.35 Stratigraphy of the Cormorant Lake Section. 
lower tills of eastern provenance.

\subsubsection{Millwater section}

East of Cranberry Portage along Athapapuskow Lake, a hand-dug hole $1.2 \mathrm{~m}$ deep exhibits multiple thin till units within a southwesterly oriented crag-and-tail landform (Fig. 2.36). At the base of the pit, a sandy, non calcareous, dark greenish grey till, enriched in greenstone belt clasts and relatively high in trace metal concentrations was observed (unit C). This lower till is overlain by a grey, fissile, calcareous (36 to $44 \%$ ), silty till, high in Ca and $\mathrm{Sr}$, and low in trace metals (unit B). A strong fabric was measured in unit B, indicating an eastern provenance $\left(259^{\circ}\right)$. The upper unit consists of a brown, non calcareous, bouldery, sandy clayey till (unit A). These three till units are separated by sharp contacts. The lower till (unit C) is likely a basal till deposited by an early 'southerly' flow of Keewatin provenance, as suggested by its local Shield provenance. The middle till (unit B) was deposited from a westerly flow (main?) of Labradorean provenance that carried carbonate debris over the Shield close to its margin. This event was followed by a southwestward advance of Keewatin provenance which deposited basal till in a southwesterly oriented streamlined landform (unit A).

\subsubsection{Mosher Lake section}

Southwest of Flin Flon near Mosher Lake, three shield-derived tills with slight compositional variations separated by sharp erosional contacts were recognized in a $2.5 \mathrm{~m}$ high roadcut section (Fig. 2.37). The lower unit is a compact, sandy silty till, and exhibits 


\section{Millwater Section}

Site 94BOU0021

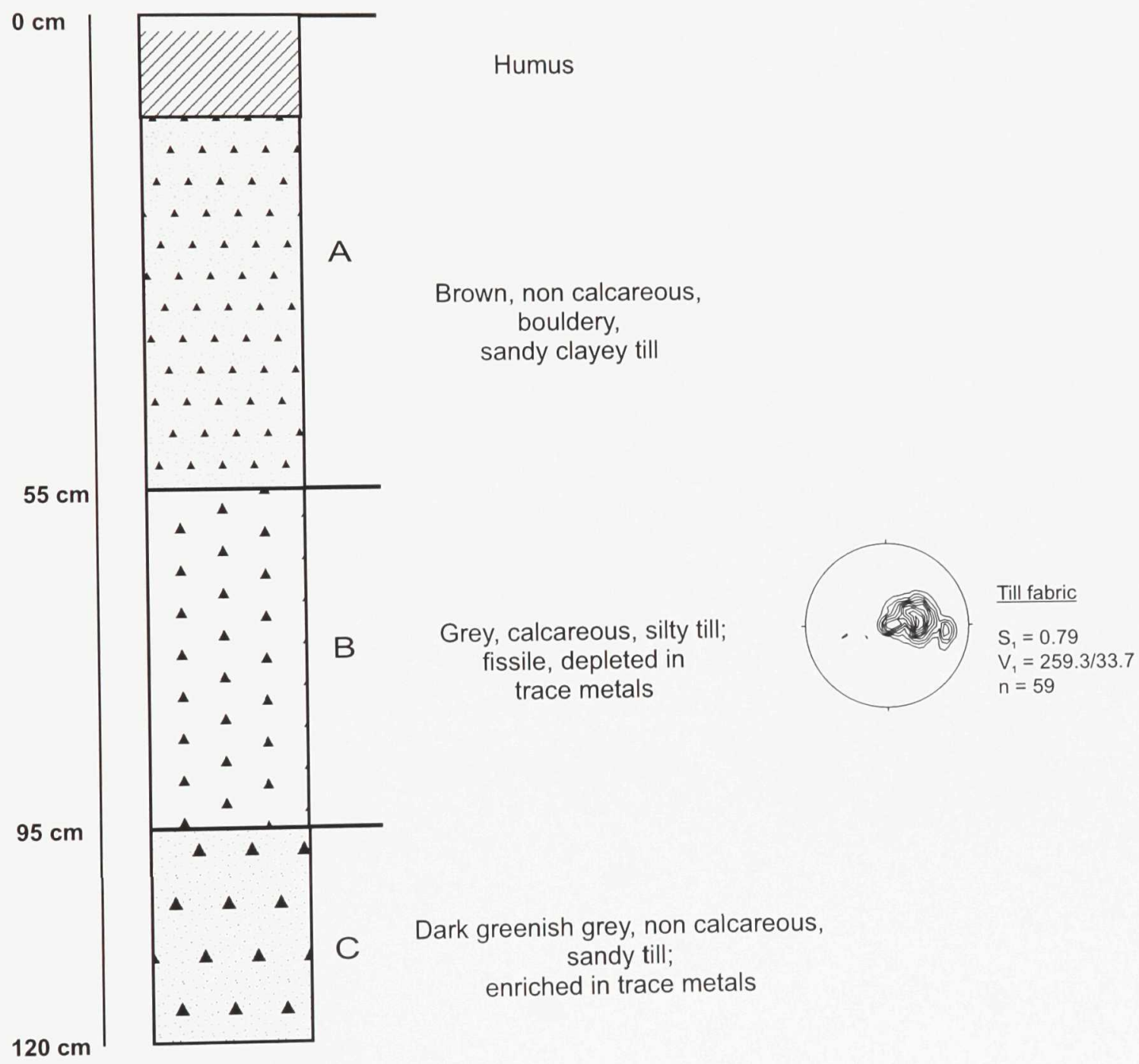

Figure 2.36 Stratigraphy of the Millwater Section. 


\section{Mosher Lake Section}

\section{Site 92HJB2036}

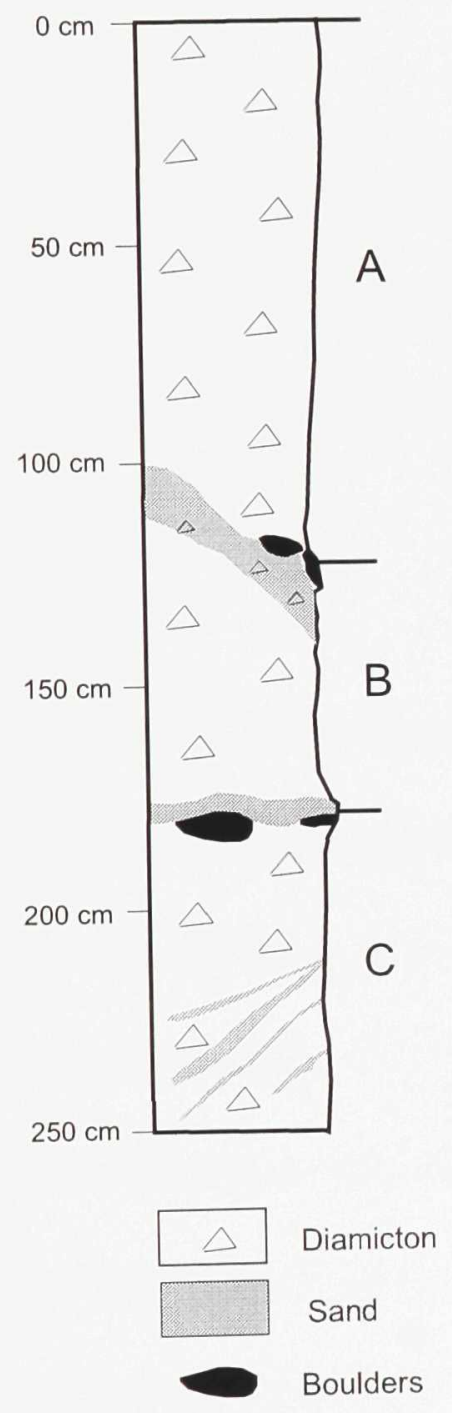

Compact, silty sandy till; interbedded diamictons and silty sand layers

fissile, bimondy diamicton

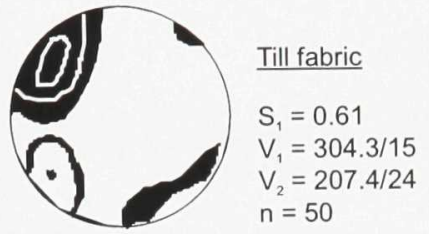

Compact, sandy silty till

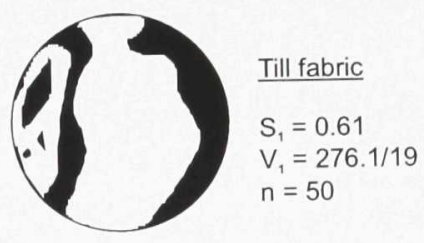

Figure 2.37 Stratigraphy of the Mosher Lake Section (modified from Henderson, 1995a). 
a strong fabric $\left(276^{\circ}\right)$, indicating deposition by Labradorean ice flow from the east (unit C). The middle unit (B) consists of a compact silty sandy till enriched in Al, Fe, and depleted in $\mathrm{Cr}, \mathrm{Ni}$, and Co compared to the underlying unit. The upper unit (unit A) is a compact, fissile, sandy till with slight compositional differences from the underlying unit. It has a bimodal fabric at $304^{\circ}$ and $207^{\circ}$, and may represent an ablation facies of the underlying till deposited presumably by the main ice flow event of Keewatin provenance (Henderson, 1995a).

\subsubsection{Glacial stratigraphy from adjacent areas}

A full understanding of the Quaternary history of the Flin Flon region relies on information derived from adjacent areas where a more complete stratigraphic record is preserved.

The oldest till documented immediately adjacent to the Flin Flon region is a very calcareous, thin, reddish brown to pale brown, stony till, found at depth under The Pas Moraine. This till occurs below a grey brown, silty till that forms the bulk of the moraine (Singhroy and Werstler, 1980). The lower red till was presumed to be deposited during an older southeasterly ice advance. West of The Pas Moraine, a red till of similar color and carbonate content was reported within southeasterly trending drumlins (Fig. 2.5), thought to have been formed by a late readvance of Keewatin ice over previously deposited red till of Labradorean provenance ("Arran till”) (Nielsen and Groom, 1987). Furthermore, at one site in the same area, Pedersen (1973) found two thick reddish brown tills separated by a thick cream-brown sandy silty till, suggesting the presence of two distinct red till units in the area. 
The upper red till, including the surface till present in the drumlins east of Westray, would be correlative with the regional surface reddish till of Keewatin provenance found west of The Pas Moraine in the Rocky Lake area. The lower red till may correspond with the thin red to orange brown till found on either side of The Pas Moraine overlying bedrock striated from the east. Therefore, this lower till would have a Labradorean provenance, in contrast with the suggestion of Singhroy and Werstler (1980).

Near Grand Rapids, south of the study area, Klassen (1967) noted two tills in sections: a light grey, compact, silty stony till at the base, which he thought was deposited by a southeasterly flow of Keewatin ice, overlain by a very pale brown to grey, stony, silty till thought to have been deposited by a relatively thin glacier flowing in a southsouthwesterly direction to a position south of The Pas Moraine. In places Klassen (1967) observed that this upper till was clayey and included contorted inclusions of laminated brown sediments. From this, he concluded that the 'thin' glacier had readvanced into a lake and over lake deposits, prior to fluting the top of The Pas Moraine. Similar observations were noted at the distal end of a fluted landform over The Pas Moraine east of Wanless (McMartin, 1994b), where a thin, grey, calcareous, silty till was found over massive, finegrained glaciolacustrine sediments, suggesting that the ice lobe that moulded the till into flutings over The Pas Moraine locally readvanced into Lake Agassiz. At this site, the till below the glaciolacustrine sediments forms the bulk of the moraine and is thought to have a Labradorean provenance (eastern). 
Further south in the Swan River area (cf. Fig. 2.3), Nielsen (1988) described three different tills of Wisconsinan age which he correlated to tills named by Klassen $(1975,1979)$ in southwestern Manitoba (Table 2.2). The Minnedosa Fm at the base, consists of a calcareous, shale-rich, clayey till deposited by southwesterly (Labradorean) flowing ice during the Early Wisconsinan. The Minnedosa Fm is overlain by the Zelena Fm, a calcareous, sandy silty till deposited from the north during the Late Wisconsinan. This till would be correlative with the regional surface till of Keewatin provenance reported in the study area over the Shield and west of The Pas Moraine ('Wanless till'). The Arran till is the youngest till in the Swan River area and consists of a highly calcareous till deposited during a late glacial readvance into the Interlake area, a readvance that terminated at the Manitoba escarpment.

In central Saskatchewan, the glacial sediments and associated stratified drift of Pleistocene age have been separated into two groups, the older Sutherland Group of preIllinoian age, and the younger Saskatoon Group (Christiansen, 1968) (Table 2.2). The Saskatoon Group comprises the Floral Fm of Illinoian to Early Wisconsinan age and the Battleford Fm of Late Wisconsinan age. Schreiner (1990) proposed generally southward ice flow for these tills, although the possibility of westward flow was mentioned for the Floral Fm. The upper Floral till would be equivalent to the Minnedosa Fm in Manitoba, and possibly the old reddish till of eastern provenance in the study area. The Battleford Fm correlates in age with the Zelena Fm, and the surface regional till of Keewatin provenance in the Flin Flon region ('Wanless till'). In the Smeaton area in Saskatchewan (cf. Fig. 1.1), 

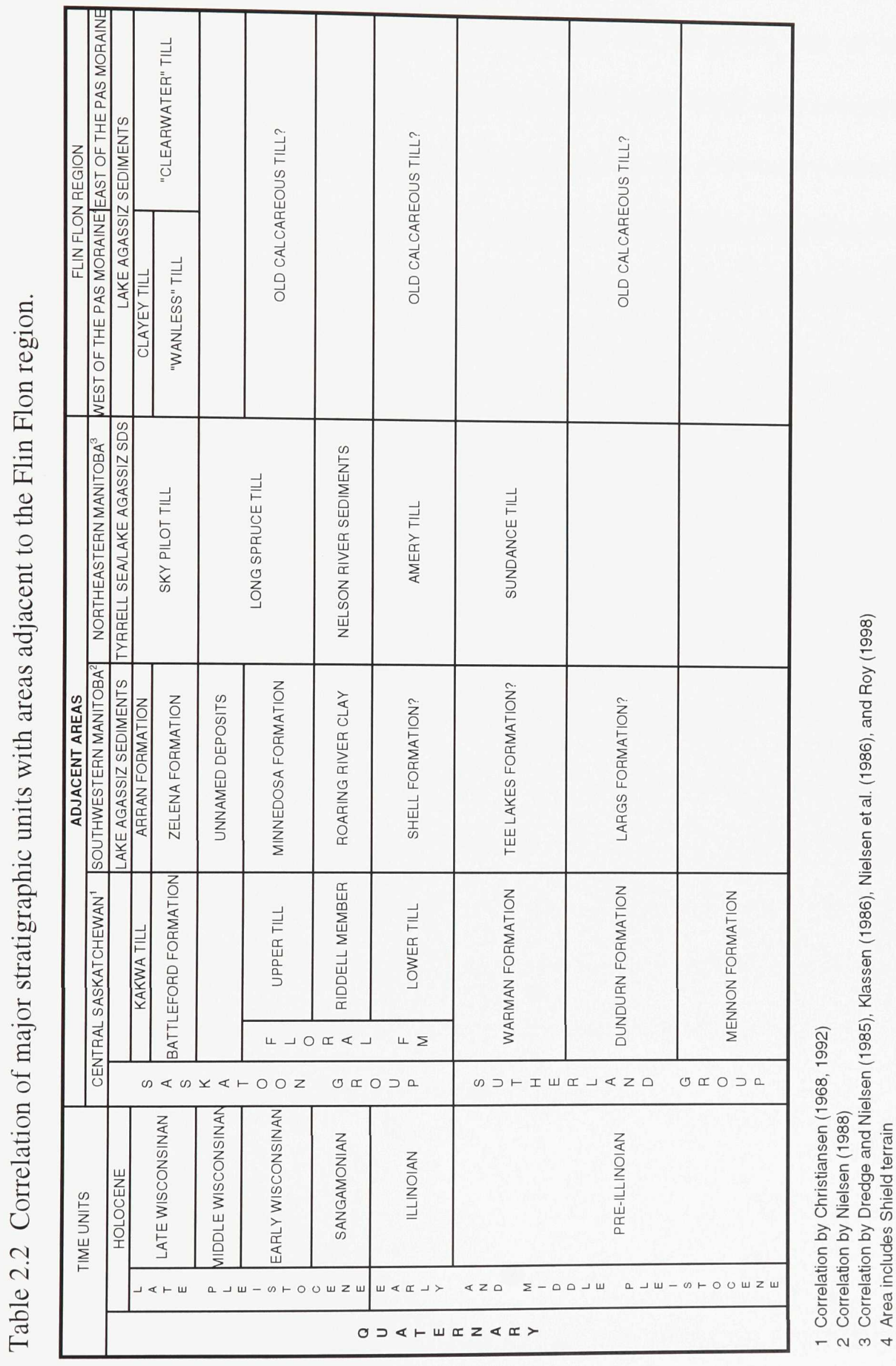
Thorleifson and Garrett (in press) have documented two calcareous tills of eastern provenance below a shield-derived till of northern provenance which they interpreted as Floral tills and Battleford till, respectively. In the Hudson Bay area in Saskatchewan (cf. Fig. 2.3), Moran (1969) also named the Kakwa till, a reddish brown, highly calcareous facies of the Battleford Fm. This till would be equivalent to the Arran till, as it was deposited from the east between the Pasquia and Porcupine Hills.

In northeastern Manitoba, the stratigraphy of the Hudson Bay Lowlands has been described by Dredge and Nielsen (1985), Klassen (1986), Nielsen et al. (1986), and Roy (1998). The Sundance till of Keewatin provenance (southeast flow) is found at the base of the sequence and is thought to be pre-Illinoian in age. The upper part of this till consists of a paleosol that is overlain by the Limestone River marine sediments. This non-glacial unit is overlain by the Amery till of eastern provenance, which is in turn overlain by the Nelson River lacustrine sediments, thought to be Sangamonian in age. The Long Spruce till of eastern provenance was deposited during the last Wisconsinan ice advance. The Sky Pilot till is the regional surface till throughout northeastern Manitoba and was deposited during the retreat of Labradorean ice. Thus, it would be correlative with the surface till found east of The Pas Moraine in the study area ('Clearwater till').

\subsection{Glacial history}

\subsubsection{Early glaciations}

The earliest ice advance recognized in the Flin Flon region was from the east, as 
recorded by old westerly ice flow indicators, the occasional presence of old calcareous tills found below younger Keewatin derived tills, and the few pebble fabrics measured in these carbonate tills. Over the Shield, their emplacement probably resulted from transport of locally derived Paleozoic carbonate debris carried from the edge of the Williston Basin, but may also include exotic debris from the Hudson Bay Lowlands. These old calcareous tills remain poorly documented in the study area. Clearly they may not have all been deposited during the same ice advance, as westerly events depositing old tills of eastern provenance appear to have spanned a large area in northern and central Manitoba and Saskatchewan (e.g., Klassen, 1979; Nielsen et al., 1986; Christiansen, 1992).

The second oldest ice flow event was southeast, from the Keewatin Sector of the Laurentide Ice Sheet. The age of this early southerly flow is unknown and no till unit that could be clearly associated with this movement has been observed in the study area. This southeasterly event is documented throughout north-central Manitoba, but conflicting ages have been attributed to this early Keewatin flow. Although attributed to the LGM by Klassen (1983), it is probably pre-LGM since south-southwestward erosional ice flow indicators and glacial dispersal trains are much more pervasive in the study area than southeasterly ones. If the southeast flow is the same responsible for depositing the old till of Keewatin provenance in northern Manitoba (Sundance till), then it could correspond to the ice flow that deposited the Warman Fm of northern provenance in Saskatchewan (Schreiner, 1990). Thorleifson and Garrett (in press) have also found that the Warman till is absent from the Smeaton area, $140 \mathrm{~km}$ southwest of the study area. Alternatively, if the old westerly event 
is Early Wisconsinan in age, then the southeasterly event documented in the Flin Flon region could have occurred during the last advance of Keewatin ice.

\subsubsection{Last glaciation}

Most of the surficial glacial deposits, streamlined features and erosional ice flow indicators in the study area formed during the last glaciation which spanned the (Late ?) Wisconsinan. The age of the last advance of the Laurentide Ice Sheet is still controversial (e.g., Shilts, 1982; Andrews et al., 1983; Dredge and Cowan, 1989; Wyatt, 1989; Berger and Nielsen, 1990; Thorleifson et al., 1993; Roy, 1998). The present state of Hudson Bay Lowland research implies that the last advance over the Flin Flon region occurred after oxygen isotope substage 5a, around $79000 \mathrm{BP}$ (Early Wisconsinan) or possibly as recently as $35000 \mathrm{BP}$ (Late Wisconsinan).

The contrasts in the direction of ice flow indicators and in the characteristics of surface till in the Flin Flon region show that at times during the last glaciation Keewatin ice covered the area, while at others, both ice masses were active and confluent in the region. The extent and vigour of the two ice masses changed, and with these changes the zone of confluence between Keewatin and Labradorean ice shifted.

Keewatin ice flowed generally south-southwestward over resistant Precambrian lithologies, and to a great extent eroded the previously deposited tills. Crossing the Shield margin, the ice continued to flow generally in the same direction. Hence, there is no 
evidence for a major southeasterly deflection of flow at the Shield boundary, as predicted by the model of Fisher et al. (1985), which assumed that it was also a boundary between hard (higher resistance to erosion) and soft (lower resistance to erosion) substrata. This southerly ice flow event appears to have affected the whole study area and adjacent areas during the last main glaciation, as recorded by the pervasive nature of south-southwesterly ice flow indicators over the Shield and by the southward decrease in Precambrian clast content over the Paleozoic cover, even in areas dominated by late Labradorean ice flows. Perhaps Labradorean ice barely influenced the southward flow of Keewatin ice during the LGM, and a zone of extensive parallel and confluent ice flow between the two ice masses developed immediately east of the study area. This southward event is equivalent to the one that deposited the Zelena till documented south of the study area in Manitoba and the Battleford Fm in Saskatchewan.

During or immediately after the LGM, Labradorean ice flowing from a dome and/or a saddle located at an undetermined position east of the region increased in intensity and a lobe originating in the Sipiwesk Lake area advanced over the region. Scant erosional microforms indicate that this ice lobe extended further west than what is indicated by the surface till sheet, at least as far as Namew Lake in Saskatchewan, $60 \mathrm{~km}$ west of The Pas Moraine. Hence, the zone of confluence of the two ice masses shifted westerly, west of the provincial boundary. However, over the Shield, the position of this zone prior to the retreat of Labradorean ice to The Pas Moraine remains undefined. 
2.7.3 Deglaciation

Keewatin ice once again regained its influence during deglaciation as Labradorean ice retreated back from the Namew Lake area to form the arcuate The Pas Moraine. Keewatin ice was deflected locally around the Labradorean ice front as indicated by the progressive shift from a south-southwesterly flow immediately south of the Shield margin to a southward flow at the southern edge of the study area. This pattern of striations, together with the morphology of the northern tip of The Pas Moraine, suggest the interference of two ice masses, and define a major interlobate position early during deglaciation. Possibly the southeasterly trending drumlins southwest of The Pas were formed by the continuation of this curving ice flow that terminated near Westray.

Late shifts in glacial flow occurred as deglaciation continued and Lake Agassiz invaded the areas proximal to the two ice masses. Keewatin ice retreated north of Flin Flon, possibly to the Cree Lake Moraine, before flow shifted to the southwest and ice readvanced in the study area. At this time, a lobe of Labradorean ice still remained in the east. The thinner Keewatin ice advanced into Lake Agassiz at least to the Rocky Lake and Namew Lake areas. Near the end of deglaciation, the flow of Labradorean ice increased in intensity once again. Its northern margin was characterized by an active west-northwest flow against Keewatin ice south of Reed Lake, marking the final position of the confluence between Keewatin and Labradorean ice at the Reed Lake Interlobate Moraine. A thin Labradorean ice lobe readvanced into Lake Agassiz no farther west than Wanless, fluting the top of The Pas Moraine. To the south, this ice lobe continued to flow into the Interlake area. Lobate 
portions of this flow occupied the re-entrants between the Pasquia Hills, Porcupine Hills, Duck Mountain and Riding Mountain uplands as far south as Dauphin, Manitoba (Klassen, 1979: Arran readvance). Keewatin ice retreated to the Annabel Lake Moraine, and Labradorean ice retreated to the Hargrave Moraine, and later to the Sipiwesk Moraine, perhaps when Keewatin ice had already retreated to the Cree Lake Moraine and Lake Agassiz had fallen to the Stonewall level (see Chapter III).

\subsection{Discussion}

2.8.1 Regime of the two ice masses and till depositional processes

Thin tills in the Flin Flon region may be the chronostratigraphic equivalents of the thicker sequences observed in the south. Pervasive erosion by Keewatin ice during the last main glaciation essentially removed any pre-existing weathered bedrock, weathered sediments, or organic material, and left a striated bedrock surface. Over the Precambrian, this advance generated a thin till cover which is sandy in texture and consists essentially of locally derived crushed Precambrian debris. Over the Paleozoic, Keewatin ice deposited a continuous but generally thin blanket of sandy silty till that is progressively enriched in Paleozoic debris, up to $50 \%$, after as little as $20 \mathrm{~km}$ of glacial transport over carbonate bedrock. Locally derived, thin till across the Shield and most of the Paleozoic terrain is likely a basal till deposited beneath active ice. Physical characteristics of the glacial sediments, such as the apparent vertical and lateral homogeneity observed in sections, the fabric and the gentle up-glacier dip of the clasts, and evidence for shear deformation, including fissility, compactness, faceted clasts, striated clasts and bullet shape boulders, 
suggest the tills were deposited by a subglacial process such as lodgement (e.g., Eyles et al., 1982; Dreimanis, 1990). Fissility is commonly (but not necessarily) considered part of the lodgement process, and results from deformation of a fluidized substrate under an applied shear stress of overriding ice (e.g., Boulton et al., 1974). No clear evidence for basal meltout processes (e.g., Muller, 1983; Dreimanis, 1988) were observed in the glacial sediments. The low bedrock relief $(<50 \mathrm{~m})$ of the area would not have permitted the preservation of stagnant basal ice blocks within bedrock basins, hence no zonal stagnation during deglaciation. This is in contrast to what Kaszycki (1987a) suggested for the exterior esker-free portion of the southern Shield in Ontario (Zone B), where basal tills are thought to have been deposited by meltout from beneath stagnant ice or from thin slabs of stagnant ice beneath an active shear zone (Kaszycki, 1987b).

Labradorean ice reworked older sediments of Keewatin provenance and deposited a fairly continuous calcareous till sheet that varied considerably in thickness: from a thin veneer over Paleozoic bedrock plateaus to a thick blanket in the intervening lowlands or at the ice front. The late-glacial radiating pattern associated with Labradorean ice flows indicate that ice thickness and glacial processes were different from the areas affected by Keewatin ice. Specifically, the radiating flow must have been fed by a narrow zone of enhanced ice supply, probably an ice stream (Clayton et al., 1985). Several lines of evidence suggest that surface till was deposited under an ice stream in the zone dominated by Labradorean ice flows : 1) the abundance and radial pattern of streamlined forms (drumlins) terminating at the arcuate The Pas Moraine, 2) the abrupt lateral variations in carbonate 
content of till and in ice flow directions along the edge of the radial flow, 3) the incorporation of fine-grained older sediments (Keewatin till) overridden by ice, 4) the presence of far-travelled calcareous till from the Hudson Bay Lowlands, and 5) the sensitivity of the radial flow to topography, as shown by its diversion to low areas between the uplands of the Manitoba escarpment. Furthermore, the flat to gently sloping dispersal profile reflects englacial transport with minimal modification of debris by crushing and abrasion, and may be characteristic of dispersal by ice streams where flow occurs by subglacial sediment deformation (e.g., Boulton, 1996). However, subglacial deformation may not characterize all of the glacial sedimentation processes for the Labradorean tills, as locally derived stony till, likely deposited by lodgement processes, is found over bedrock highs.

\subsubsection{Relation of ice flow events to position of ice divides}

The old westward event(s) recognized in the area must have been from a centre of outflow located on the eastern side of Hudson Bay at least once prior to the last main glaciation. This would account for the presence of distinctive greywacke erratics in the Prairies, derived from the Omarolluk Fm which outcrop in eastern Hudson Bay (Prest, 1990). The age of this westerly flow remains unknown but it may have originated from a dome centered in east-central Québec, which was suggested by the presence of old west-northwest striations in northern Ontario and adjacent Québec (e.g., Thorleifson, 1989; Veillette, 1995; Parent et al., 1995). Veillette et al. (1999) recently proposed that these northwesterly ice flow indicators resulted from the expansion of an Early Wisconsinan glacier in the Québec highlands. 
The old southeasterly ice flow may have been the same as that producing the southeasterly striations recorded by Dredge et al. (1986) and others in northern Manitoba, hence the centre of "Keewatin" outflow would have been in the District of Mackenzie (Northwest Territories). Alternatively, the southeasterly flow could result from the expansion of a Keewatin glacier prior to the LGM. The shift from a southeasterly flow to a more south-southwesterly flow, therefore, could have been in response to an eastward migration of an ice divide originally located in the District of MacKenzie. McMartin and Henderson (1999) have recently documented a complex ice flow history in south-central Nunavut, including a clockwise shift of ice flow during the last Wisconsinan (?) glaciation, interpreted as an eastward migration of a dispersal centre within the Keewatin Sector of the Laurentide Ice Sheet.

The predominant south-southwesterly ice flow attributed to the LGM in the Flin Flon region, and recognized throughout north-central Manitoba and Saskatchewan, demonstrates that a major centre of outflow was located in Keewatin during the last main glaciation. This is unlike what is depicted by Dyke and Prest (1987a) at $18 \mathrm{ka} \mathrm{BP}$, who showed a dispersal centre in the District of MacKenzie, and a saddle connecting Keewatin Sector ice and Labrador Sector ice domes inland in northeastern Manitoba. However, the Keewatin dispersal centre during the LGM would have been closer to the Mackenzie-Keewatin District (Northwest Territories - Nunavut) boundary than the position of the Keewatin Ice Divide (Shilts, 1980). 
If Late Wisconsinan southwestern flow across the entire HBL requires a saddle $\underline{\text { in }}$ Hudson Bay (Thorleifson and Kristjansson, 1993), then the configuration postulated by Dyke and Prest (1987a) at about 11 ka years BP can also explain the late-glacial westerly flow of Labradorean ice recorded in the study area. However, as suggested by Thorleifson et al. (1993), the presence of a dome over southwestern Hudson Bay ("Hudson" ice), as portrayed by Dyke et al. (1982) and by Dyke and Prest (1987a) at $\underline{10} \mathrm{ka} \mathrm{BP}$, is not required.

\subsection{Conclusions}

The glacial geology record present in the Flin Flon region is of importance for understanding the glacial history of Canada and for direct applications such as drift prospecting. The glacial erosional record, mainly striations and roches moutonnées, reflects complex multiple ice flow events, which mostly relate to the last cycle of glacial advance and retreat, at the confluence of two major Sectors of the Laurentide Ice Sheet. The glacial depositional record, mainly surface till, is characterized by contrasting composition, distribution and thickness on either side of the Shield edge, and contrasting provenance and glacial sedimentation processes related to different ice flow dynamics between the two major ice masses. The rare occurrence of older glacial and non-glacial sediments beneath surface till demonstrates almost complete glacial erosion during succeeding glacial events.

Glacial history interpreted from the ice flow record and till characteristics represent the first comprehensive study of the Quaternary geology of the Flin Flon region on either side of the provincial boundary. An early westward flow from a Labradorean dispersal centre was 
recorded throughout the entire area, as evidenced by old westerly striae and the preservation of old calcareous tills. Its age remains unknown but could be as old as pre-Illinoian, or as young as Early Wisconsinan. This event was followed by a regional southeastward flow from a Keewatin Sector dispersal centre that was probably located in the Northwest Territories (District of MacKenzie). The age of this ice advance is also unknown; it could have occurred immediately prior to an Illinoian glaciation that covered most of northeastern Manitoba and possibly north-central Saskatchewan, or it could be attributed to the advance of Keewatin ice immediately prior to the LGM, and consequently, be of Wisconsinan age.

During the last glacial maximum, ice flowed south-southwesterly across the entire study area from a Keewatin Sector dispersal centre probably located near the Northwest Territories-Nunavut boundary. Keewatin ice deposited a thin, discontinuous, locally derived till over the Shield, by subglacial processes. Over the Paleozoic, Keewatin ice was also highly erosive, however, because of the greater erodibility of Paleozoic carbonate rocks, the ice deposited a more continuous veneer of locally derived till, up to several meters thick.

As deglaciation proceeded, late-glacial readjustments of flow patterns in disintegrating ice masses occurred. A lobe of Labradorean ice surged across the southern part of the study area, and formed The Pas Moraine at its terminus. This created a suture zone between the two Sectors of the LIS. Keewatin ice retreated probably north of the study area before it readvanced to the southwest in Lake Agassiz, depositing a thin, discontinuous, clayey till over most of the Shield and west of The Pas Moraine. Labradorean ice flow 
shifted along the ice margins and the glacier readvanced into Lake Agassiz, locally redistributing glacial and glaciolacustrine debris. Ice flow dynamics may have been significantly different in areas glaciated by late Labradorean ice where till was possibly deposited under an ice stream by subglacial deformation. There, the till composition reflects a mixing of local and distal provenance, specifically incorporation of old Keewatin tills, long-distance transport of erratics, and the uptake of locally derived carbonate debris over bedrock highs. A locally derived, stony till was deposited by Keewatin ice in a large eastwest interlobate zone south of the Shield margin, marking the last position of the zone of confluence between the two Sectors at the Reed Lake Interlobate Moraine. Drawdown associated with these late ice flows would have contributed to the thinning of glacial ice in the area, which eventually led to deglaciation of the area by calving. 


\section{CHAPTER III: PALEOGEOGRAPHY OF LAKE AGASSIZ AND REGIONAL POST-GLACIAL UPLIFT HISTORY}

(a paper accepted in Journal of Paleolimmology, by I. McMartin )

\subsection{Introduction}

As ice sheets melt and break up as icebergs, and as meltwater is transferred to ocean basins, the shape of the earth is deformed in response to shifting ice and water loads (Peltier, 1994). The amount and direction of the earth's surface tilting, consequent to the relief of glacial load, is of prime importance to a number of disciplines, including ice sheet reconstruction, mantle rheology, climate change, shoreline erosion and lake level histories, and paleoceanography. Present models of vertical earth surface motions induced by the Laurentide Ice Sheet load are based largely on relative sea-level data (Tushingham and Peltier, 1991, 1992; Peltier, 1994; Dyke, 1996). Although high-precision geodetic measurements of present uplift are becoming available in the mid-continent, much uncertainty remains for most of post-glacial time (James and Lambert, 1993; Lambert et al., 1998; Tackman et al., 1998). Long term records of vertical motion as recorded in relative lake level histories represent an important source of information for the North American continent.

The Flin Flon region, in central Manitoba and Saskatchewan (Fig. 3.1), was completely inundated by Lake Agassiz, which formed in the Hudson Bay drainage basin during deglaciation. In this area, the record of post-glacial tilting from Lake Agassiz 


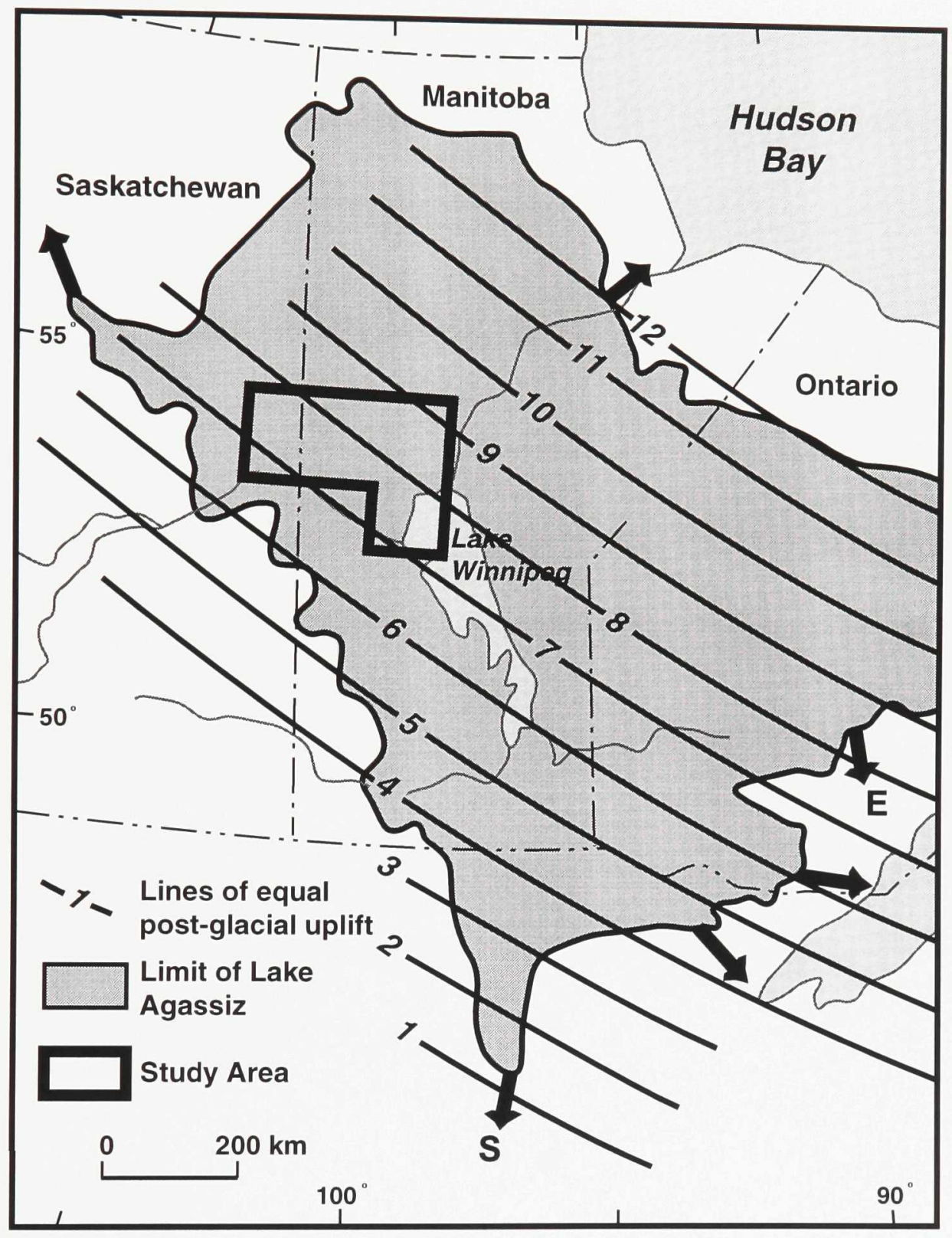

Figure 3.1 Maximum extent of Lake Agassiz with isobases showing mean trend of lines of equal post-glacial uplift (after Teller and Thorleifson, 1983). The approximate location of major outlets are also shown, including the southern outlet (S) and eastern outlets to Lake Nipigon (E). 
strandline data has not been fully exploited. Limited work has been done in the central parts of the former Lake Agassiz basin since the work of Tyrrell (1891), Johnston (1946) and Elson (1967). Mapping of beaches is still incomplete, strandlines are poorly developed on the Precambrian terrain and Lake Agassiz water planes are less well known than recent synthesis seem to imply. Particularly, late beaches formed just before the final drainage of Lake Agassiz were thought to have very low gradients by Upham (1895), Johnston (1946) and Elson (1967), but much higher gradients were suggested by Teller and Thorleifson (1983). New geological mapping in the Flin Flon region as part of the Geological Survey of Canada's National Geoscience Mapping Program (NATMAP) has provided a good opportunity to report on well preserved Lake Agassiz strandlines in the glaciolacustrine Grass River Basin and along The Pas Moraine (Fig. 3.2). The objectives of this paper are to (1) report on new strandline elevations for the Flin Flin region, (2) make shoreline correlations from new and existing data and propose a history of Lake Agassiz configuration for the last stages of its history, (3) correlate the mapped levels to ice margins and outlets, and (4) discuss inferred differential uplift rates.

\subsubsection{Previous research}

From his work in southern Manitoba, Upham (1890, 1895) proposed a named sequence of shorelines, including the lowest Stonewall level, and was the first to recognize that Lake Agassiz strandlines had a gradual ascent from south to north. However, by reporting that the gradient was "greatest in the earlier and higher beaches, and slowly diminished through the lower stages of the lake, being at last slowly different from the level 


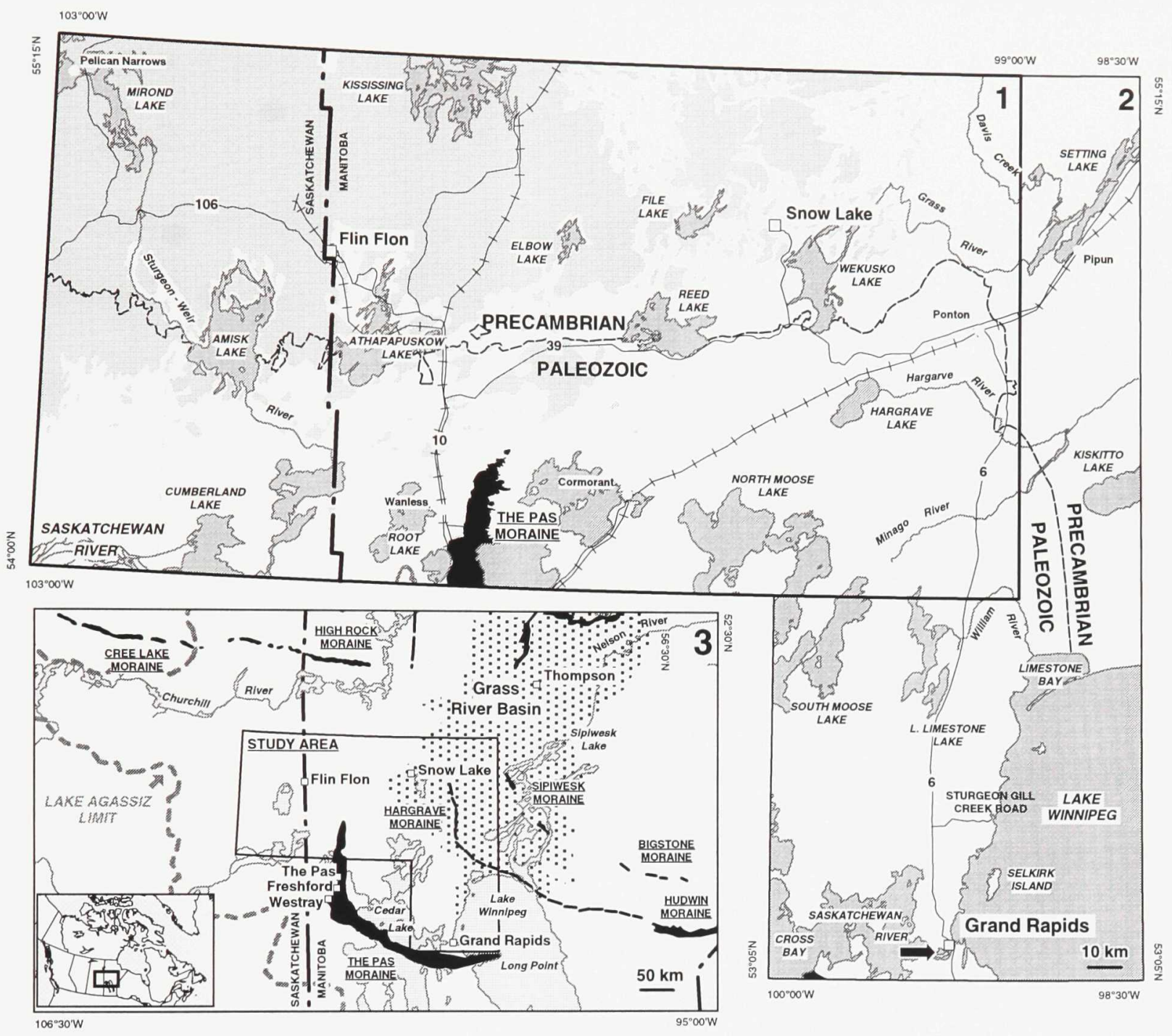

Figure 3.2 The study area in Saskatchewan-Manitoba showing major physiographic features and geographic locations. 1- Shield Margin NATMAP area where detailed surficial mapping activities were concentrated in 1991-1994. Land above 1000 foot contour is shaded. 2- Area where strandlines were identified by air photo interpretation with some ground truthing in 1995. 3- Location map of study area within central Manitoba and Saskatchewan showing location of major moraines (from Fulton, 1995), Grass River Basin (from Klassen, 1986), and maximum limit of Lake Agassiz (from Teller et al., 1983). 
of the present time" (Upham, 1890: $90 \mathrm{E}$ ), he thought that the uplift was completed before the final retreat of the ice sheet.

Tyrrell $(1891,1917)$ was the first to examine shorelines in the Flin Flon region and reported several elevations from the Grand Rapids area, and along the railway between The Pas and Ponton (Fig. 3.2). Johnston (1919) re-examined some of the beaches measured by Tyrrell and measured new ones along the same railway transect. Johnston (1946) subsequently presented the first Lake Agassiz shoreline diagram based on previous work and new strandline elevations he measured mainly from southern Manitoba. He named The Pas, Lower Pas, Gimli and Grand Rapids levels, adding to the named sequence of Upham. Johnston significantly improved the Lake Agassiz shoreline model, and established that the once-level shorelines of Lake Agassiz had been tilted up to the northeast by differential postglacial rebound. However, similar to Upham, he suggested very low gradients for the lower levels, and thought that uplift had "ceased in the Hudson Bay region some hundreds or one or two thousands of years ago" (Johnston, 1946: p. 15).

Although early exploration had recognized several Lake Agassiz shorelines, major errors were made in the correlation of beaches in the north with other better known levels to the south. The idea that the late shorelines of Lake Agassiz were nearly horizontal and that little or no tilting had occurred in post-Lake Agassiz time persisted until the late sixties with the work of Elson (1967), who portrayed a very low gradient for a hypothetical low paleowater plane named the Pipun. Later, Grice (1970), Ringrose (1975), Bell (1978) and Klassen 
(1983) reported shoreline observations between Grand Rapids and Davis Creek, some of which were recognized earlier by Tyrrell and Johnston. Teller and Thorleifson (1983) presented a shoreline diagram that schematically depicted observations by Johnston (1946), Dredge (1983) and Klassen (1983) and was in part based on correlation to Lake Ojibway, Lake Superior, and Hudson Bay. More recently, a revised schematic shoreline model presented by Thorleifson (1996) included a named Drunken Point level. Tackman et al. (1998) have reported Holocene post-glacial tilting in southern Manitoba based on paleoshoreline evidence from Lake Winnipegosis and Dauphin Lake south of the study area, and from the Burnside shoreline of Lake Agassiz. Rayburn (1997) reported elevation measurements from the Campbell strandlines along the northwestern margin of the lake basin. At the commencement of the present research, however, there remained a lack of any clear demonstration of the actual gradient of northern Lake Agassiz shorelines supported by field observations and published data.

\subsubsection{Physiography and geological setting}

The study area straddles the Paleozoic/Precambrian Shield boundary in central Manitoba and Saskatchewan (Fig. 3.2), which results in marked differences in physiography and drift thickness on either side of the Shield margin. On the Precambrian terrain, relief is undulating and glacial sediments are thin $(<3 \mathrm{~m})$ and discontinuous. Over Paleozoic rocks, relief is flat, forming an eastward sloping plain interrupted by low dolostone mesas, and sediments are generally thicker and more continuous. Fine grained glaciolacustrine sediments form a discontinuous veneer over the entire study area, generally increasing in 
thickness eastward. The eastern and southern portions of the study area, including Lake Winnipeg and Saskatchewan River, drain into the Nelson River towards Hudson Bay. The northern areas are part of the Churchill River Basin which also drain into Hudson Bay. During deglaciation, Lake Agassiz formed in front of the retreating ice margin which blocked normal drainage to Hudson Bay, between about 12 and 8 ka ${ }^{14} \mathrm{C} \mathrm{BP}$ (Clayton and Moran, 1982).

Two areas of thick sediments provided substrates for strandline formation in the study area. The Pas Moraine, composed of up to $80 \mathrm{~m}$ of till, forms an arcuate morainic ridge extending from the Wanless area to Long Point in Lake Winnipeg (Fig. 3.2). The moraine is a prominent glacial feature in central Manitoba and forms a major topographic high with an asymmetrical profile, where the down-ice steeper slope provided a steady supply of material to the shoreline. The Hargrave Moraine, named by Tarnocai (1970), is shown on glacial maps of Canada between Limestone Bay of Lake Winnipeg and Grass River (Dyke and Prest, 1987a; Fulton, 1995)(Fig. 3.2), but both morphologic and compositional expressions of the moraine are poorly defined in the study area. Only a low and broad plateau covered by fine grained glaciolacustrine sediments, behind which a radiating array of flat-topped eskers terminates, is found east of Hargrave Lake (McMartin, 1999a). The subdued landform reflects perhaps a subaqueous origin, but more likely burial under thick glaciolacustrine sediments since the position of the Hargrave Moraine is located in the centre of a paleo-Lake Agassiz basin, referred to as the Grass River Basin by Elson (1967). The basin is controlled by a depression at the shield margin, which includes Lake Winnipeg, and 
extends north towards Thompson (Fig. 3.2). The depression formed a major axis of fine textured glaciolacustrine sediment accumulation and a belt of thick sediments is found in its center (Fig. 3.3). The southwestern margin of this belt is bordered by a $30 \mathrm{~m}$ high eastward facing bedrock escarpment which marks the contact between Ordovician and Silurian rocks (Manitoba Energy and Mines, 1980). Clay thickness in the glaciolacustrine belt averages 18 $\mathrm{m}$ but may reach up to $44 \mathrm{~m}$ in the study area (Viljoen et al., 1996), and over $100 \mathrm{~m}$ in the north basin of Lake Winnipeg (Todd et al., 1998). Elson (1967) suggested that the Grass River Basin functioned from about the Stonewall level to the final drainage of Lake Agassiz.

\subsection{Location and description of strandlines}

Abandoned Lake Agassiz beach ridges, spits, bars and wave-cut scarps were mapped from aerial photographs (1:60000) as part of surficial mapping activities at the scale of 1:100 000 within the Shield Margin NATMAP area in 1991-1994 (Fig. 3.2, Area 1). South of the NATMAP area along Highway 6, aerial photographs (1:15 000) were examined and major strandlines were compiled in 1995 (Fig. 3.2, within Area 2). The elevation of the most continuous strandlines was determined with a Wallace and Tiernan surveying altimeter (Model FA181210, $\pm 1 \mathrm{~m}$ ) for the NATMAP area and an Atmospheric Instrumentation Research digital barometer (Model AIR-HB-1A, $\pm 0.5 \mathrm{~m}$ ) south of the NATMAP area when features were accessible. The altimeter measurements were calibrated in the field with known altitudes of surrounding bench marks (Geodetic Survey of Canada, 1980a, 1980b; Geomatics Canada, 1995). The crests of beach berms or the tops of spits were measured. The height of these beach ridges ranged from 1 to $4 \mathrm{~m}$. Elevations of wave-cut scarps, the 


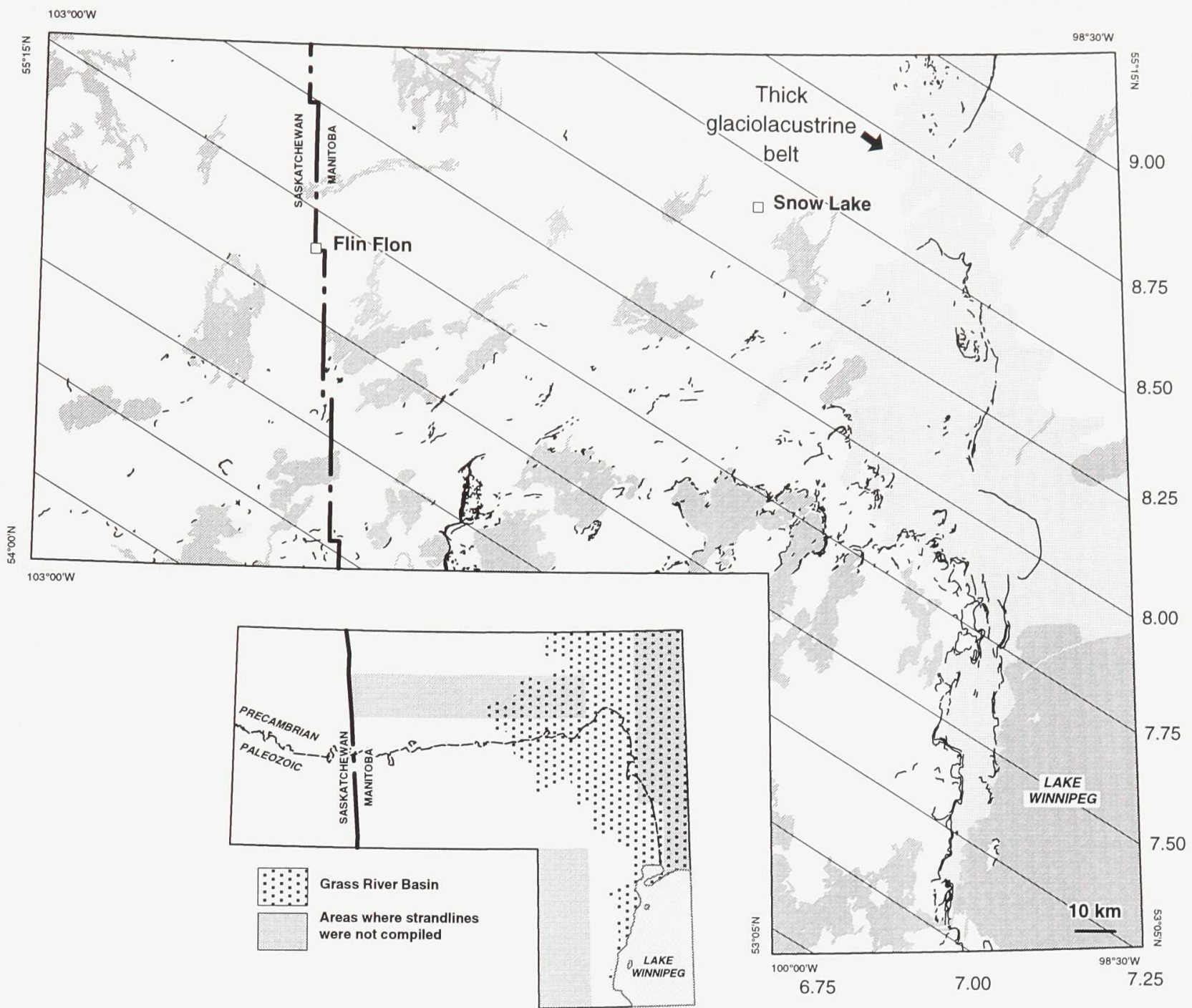

Figure 3.3 Location map of strandlines compiled in the study area. Lines of equal postglacial uplift derived from Lake Agassiz isobases 7, 8 and 9 of Teller and Thorleifson (1983) were traced at $25 \mathrm{~km}$ intervals. A thick belt of fine grained glaciolacustrine sediments is shown in the middle of the Grass River Basin (modified from Klassen, 1986; McMartin, 1994a, 1997a, 1999a). Inset map shows location of Grass River Basin and areas where strandlines were not digitally compiled on the above map. 
base of old shore cliffs, were rarely measured because of poor development, and lack of continuity. Strandline elevations were also determined from 1:50 000 topographic maps with $10 \mathrm{~m}$ or 25 feet contour intervals, or compiled from the literature. The elevation uncertainty on the strandlines, which reflects a combination of surveying error, reference elevation uncertainty and geomorphic noise related to shoreline-forming processes (Tackman, 1997), can reach $\pm 10 \mathrm{~m}$ in the case of elevations determined from topographic maps. Table 3.1 gives a complete listing of strandline elevations recently measured in the Flin Flon region, and others compiled from the literature. Figure 3.3 shows the location of strandlines compiled within the study area. The following section is a description of the major strandlines, from highest to lowest shorelines.

\subsubsection{Stonewall}

Well developed beach ridges are present along the western slope of The Pas Moraine north of the town of The Pas (Fig. 3.3). The highest most continuous ridge that skirts around the northern tip of The Pas Moraine near Wanless is correlated with the Stonewall level. Its elevation increases from 311.3 to $316.0 \mathrm{~m}$ towards the north. In Saskatchewan, several segments of beaches, wave-washed surfaces and nearshore sand blankets are probably attributable to this level, based on correlation with measurements taken along the moraine. The Stonewall beach was first named and described by Upham (1890) from his work in southern Manitoba. Johnston (1946) identified seven or eight shorelines above The Pas beaches in southern Manitoba which he considered as belonging to the Stonewall series. 


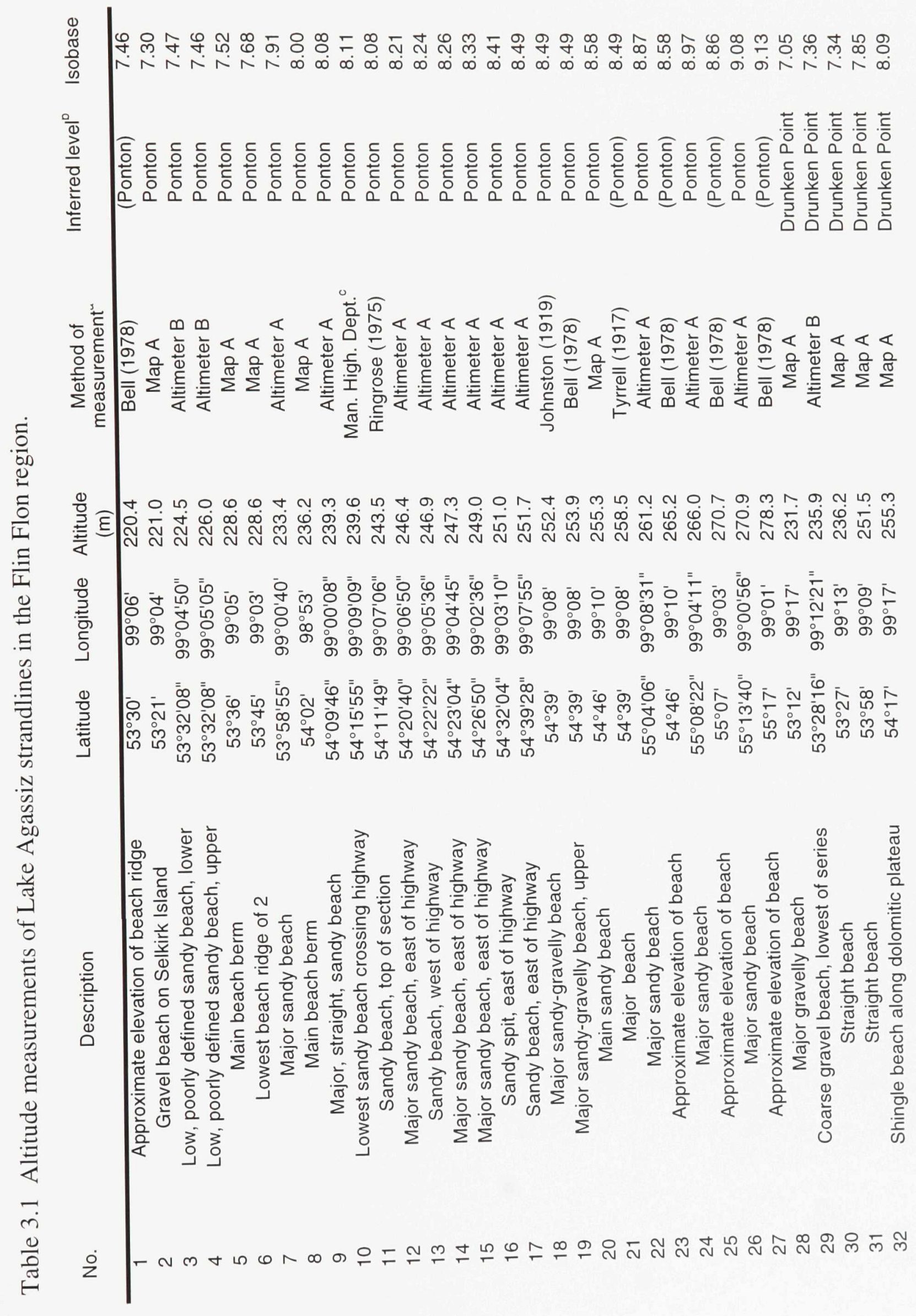




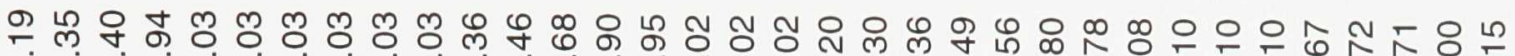

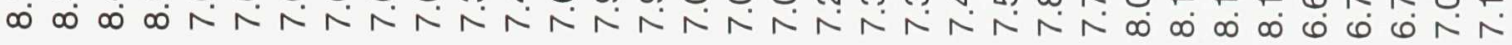

픙

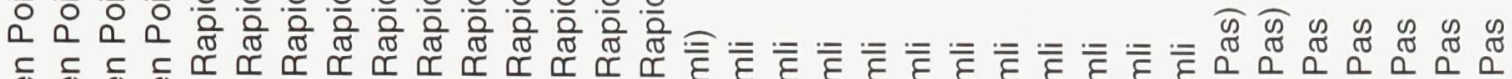

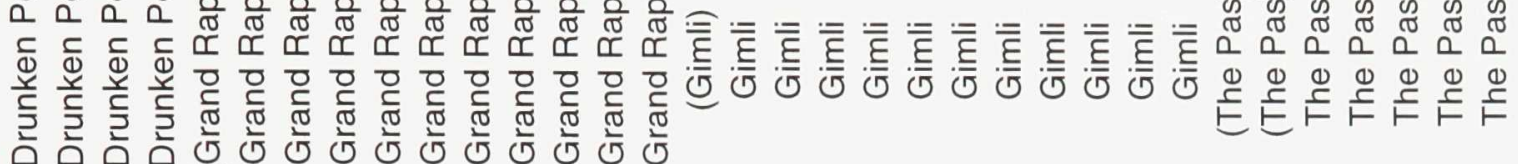

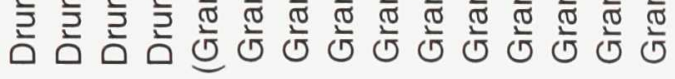

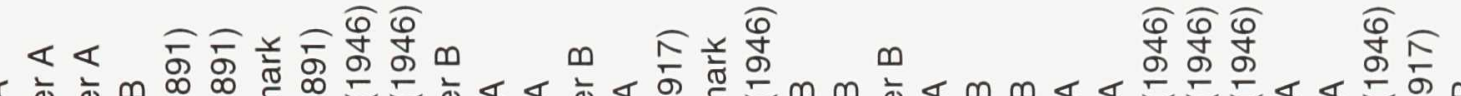
$\varangle$

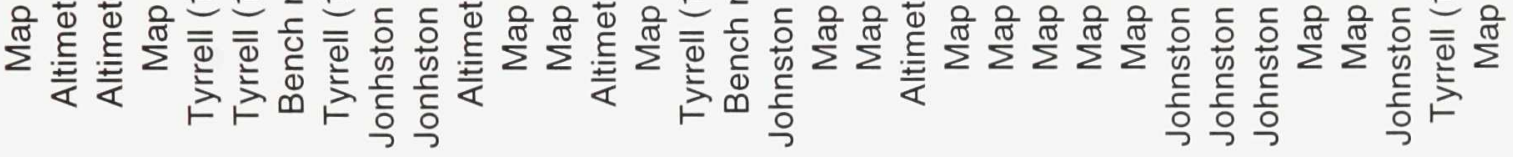

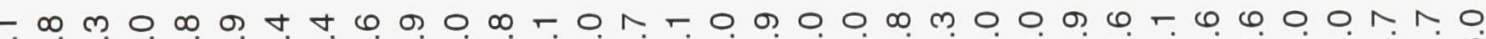
灾

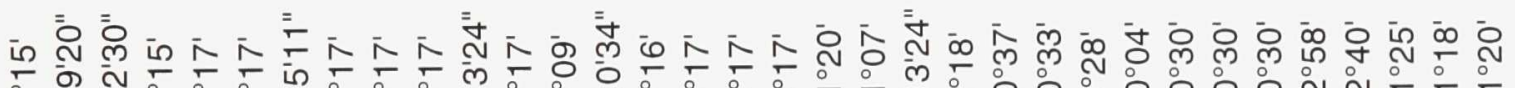

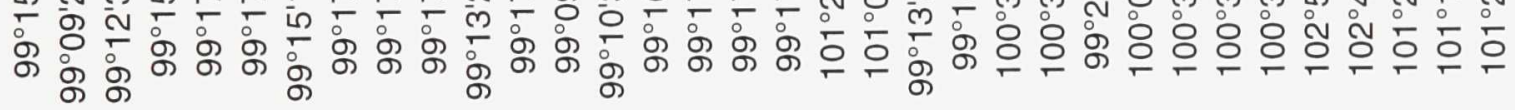

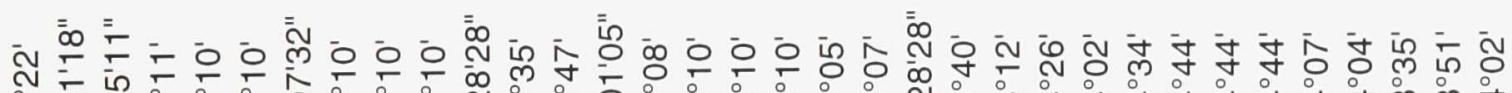

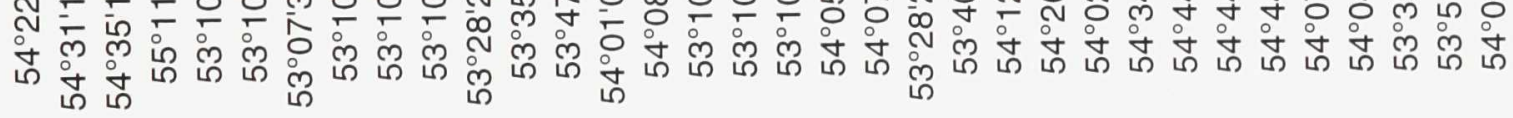

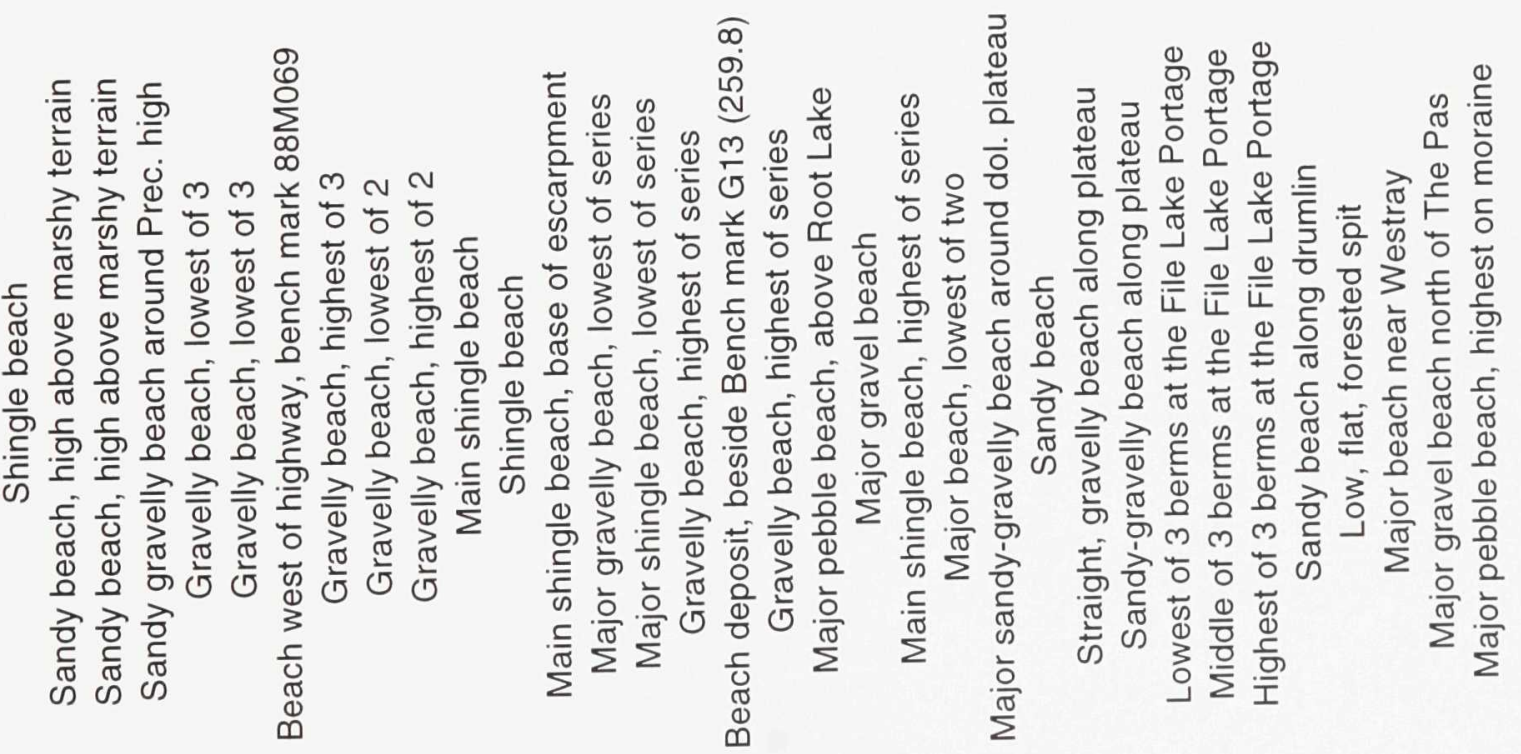

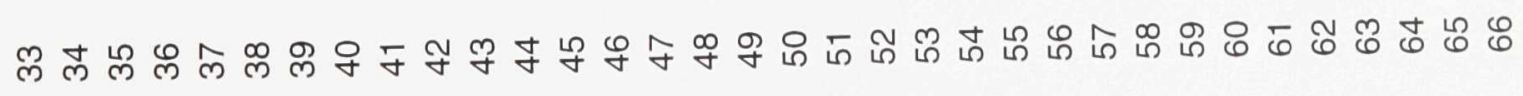




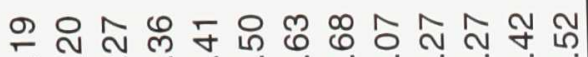
$N N N N N N N N$

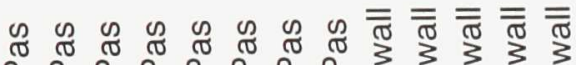
0
0

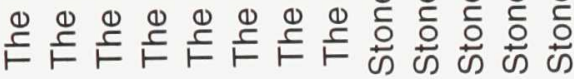

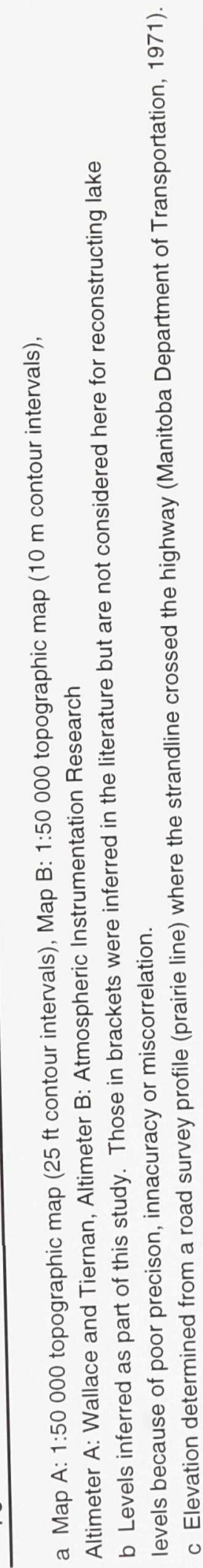

$00-0.0000 \infty 000-$

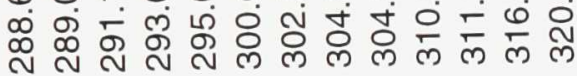

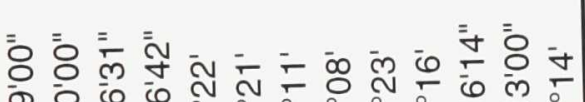

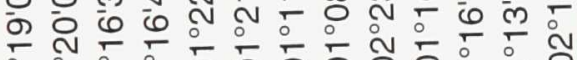

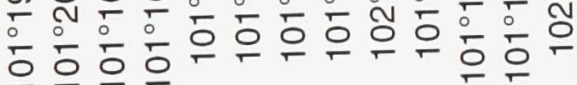

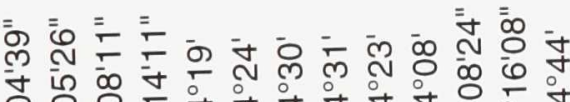

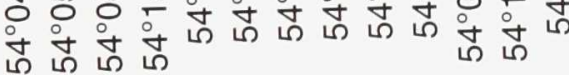

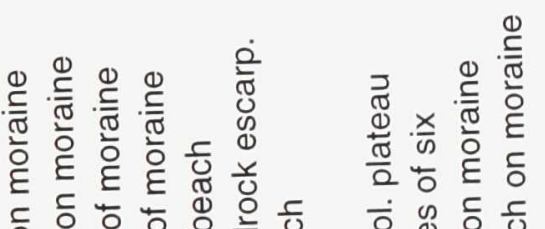

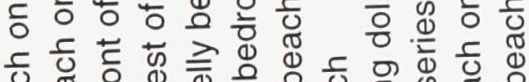

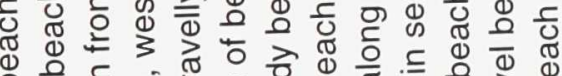

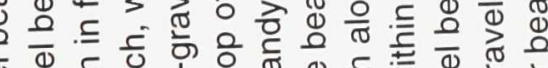
ब क人 के

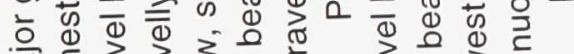

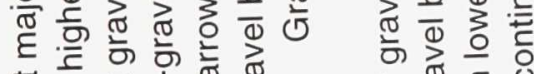

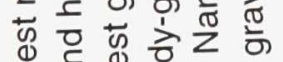

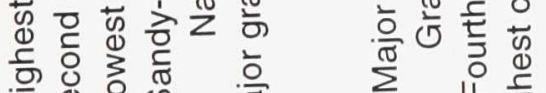

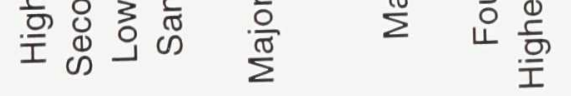

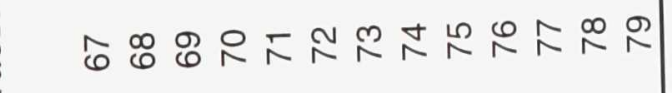




\subsubsection{The Pas}

North of The Pas, a major pebble beach ridge is present about $25 \mathrm{~m}$ above Root Lake on the crest of The Pas Moraine (Fig. 3.4a). The beach ridge skirts around Root Lake, traverses the highway towards the northeast becoming the lowest strandline in front of the northerly trending moraine, and extends for about $25 \mathrm{~km}$ until it is lost around the gently sloping up-ice side of the moraine. Elevations of this shoreline increase from $286 \mathrm{~m}$ east of Root Lake to 293 m near the northern extremity of the moraine. Elsewhere on the Paleozoic cover, numerous 2- to 5- km-long, well-developed beach segments occur north of Saskatchewan River on the slope of plateaus covered with till. On Precambrian terrain, the scarcity of beach ridges prevents neither correlation between beach segments nor association with The Pas level.

Most of the elevation measurements previously recorded on The Pas beaches are available from the down-ice steeper slope of The Pas Moraine. Johnston (1946) reported two beaches south of The Pas which he named the Upper Pas and the Lower Pas beaches. He traced the upper one for nearly 20 miles along the railway from Westray at 898' (273.7 m) north to about three miles south of The Pas at 906' (276.2 m) (Fig. 3.2). Johnston (1946: p. 4) reported that the upper beach ridge he measured was "continuous except for a break about midway, near Freshford". Examination of airphotos and topographic maps from this area reveals that the ridge measured by Johnston north of Freshford is lower and distinct from the upper one measured at Westray, this latter skirting around the other side of the moraine at Freshford. Tyrrell (1917) had previously examined several shorelines along the 


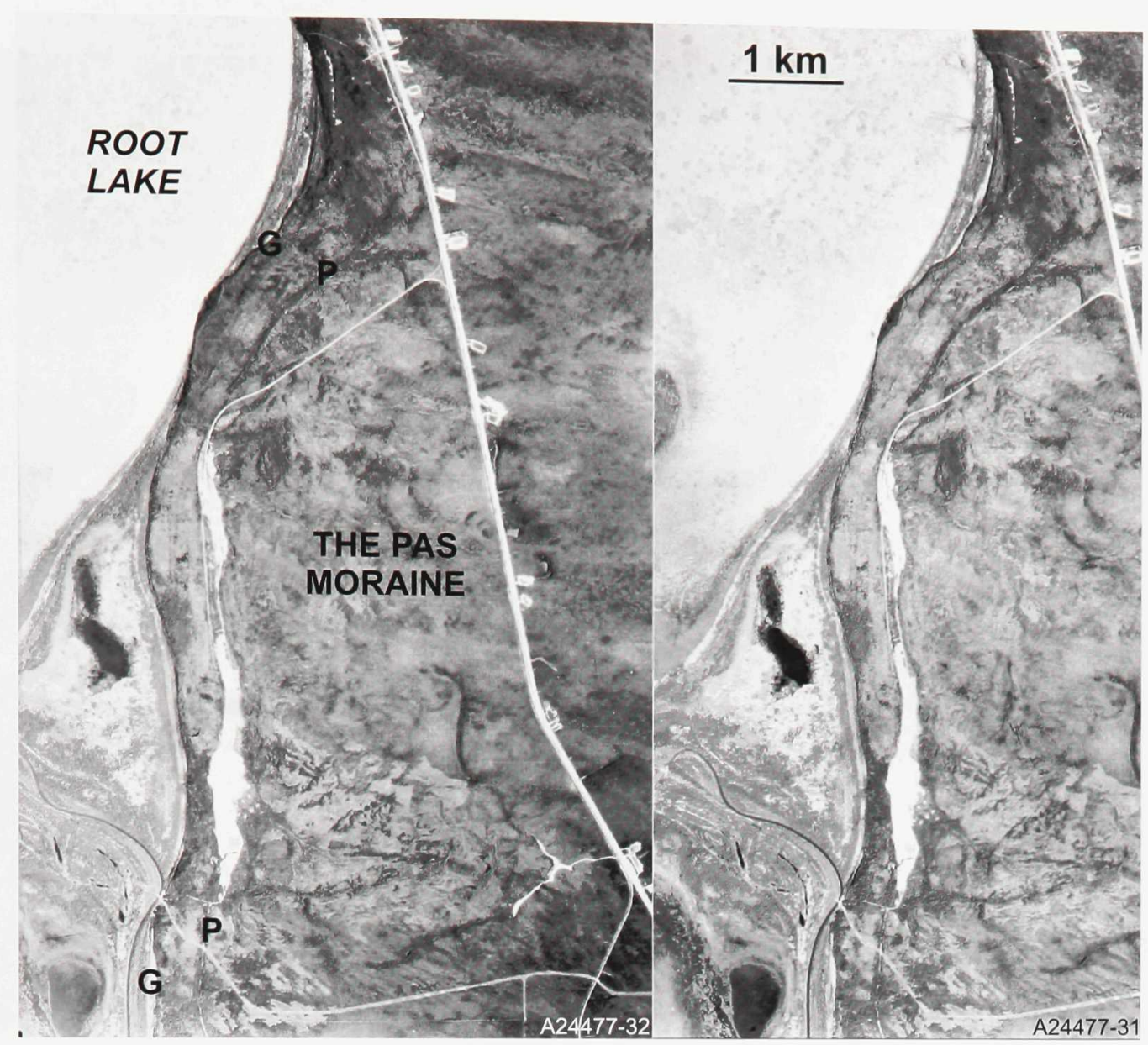

Figure 3.4 Stereopairs showing strandlines of different levels. Capital letters indicate Drunken Point (D), Grand Rapids (R), Gimli (G) and The Pas (P) strandlines.

(a) Coarse gravel beaches along The Pas Moraine east of Root Lake. 


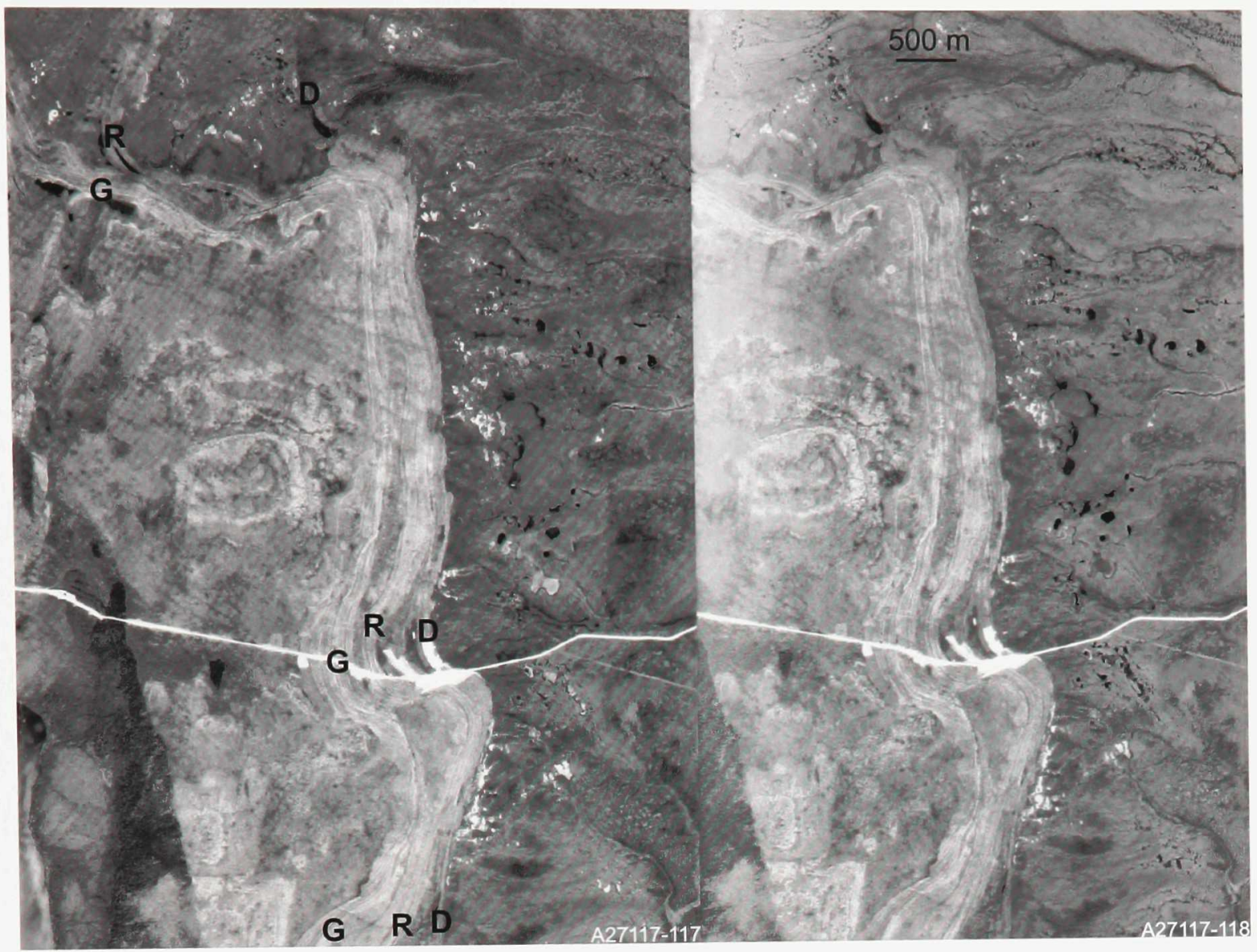

(b) Series of coarse gravel beaches along eastward facing bedrock escarpment across the Sturgeon Gill Creek road. 


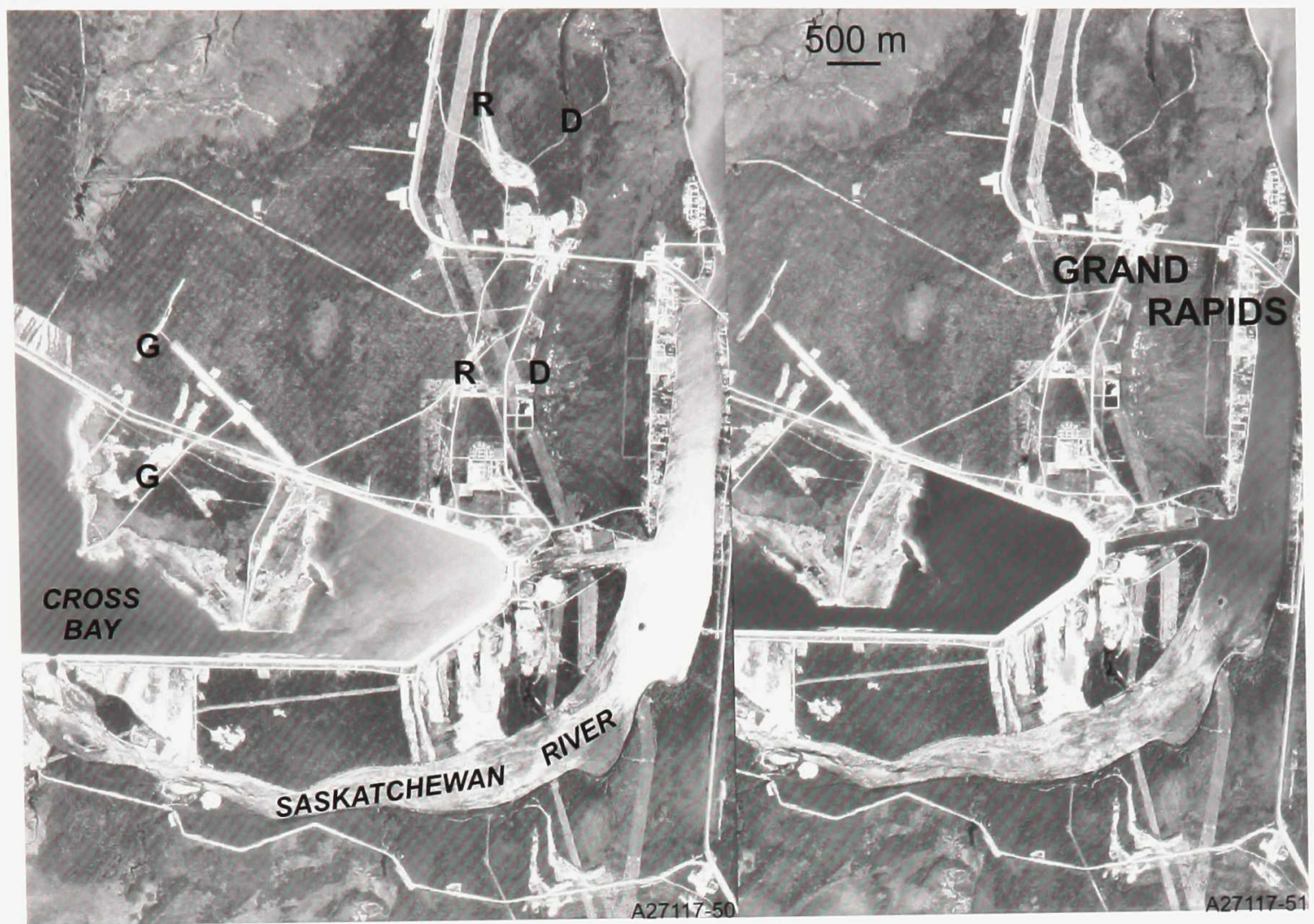

(c) Major strandlines near Grand Rapids. 
railway near The Pas and reported a strong gravel beach at $880^{\prime}(268.3 \mathrm{~m})$ in The Pas and a higher beach two miles north of The Pas at 924' (281.7 m). Therefore, The Pas shoreline documented here is correlated to the higher ridge north of The Pas measured by Tyrrell, and to the Upper Pas of Johnston measured at Westray.

\subsubsection{Gimli}

A flight of coarse gravel beaches and wave-cut scarps are found along the Paleozoic bedrock escarpment near the Sturgeon Gill Creek road (Fig. 3.2). The highest of the shingle beach series at $271.8 \mathrm{~m}$ is thought to pertain to the Gimli level of Lake Agassiz, defined by Johnston (1946) (Figs. 3.4b and 3.5a). North of William River, the strandline follows a gentle step in Paleozoic plateaus that seem to correspond to a lithological contact between two Silurian Formations within the Interlake Group (Manitoba Energy and Mines, 1980). Another long segment of a gravel beach occurs at the base of the western flank of The Pas Moraine at $268 \mathrm{~m}$, about $8 \mathrm{~m}$ above Root Lake (Fig. 3.4a). Elsewhere on Paleozoic terrain, beach segments are occasionally present along the sides of easterly oriented drumlins or around the northeast part of dolomitic mesas that gently slope to the southwest (Fig. 3.5b). Few measurements were estimated where the beaches follow a topographic contour. Nowhere can Gimli beaches be identified as such on the Precambrian hills.

The Gimli shoreline had been reported earlier only near Grand Rapids within the study area. The examination of pre-hydro-electric development and modern air photos at Grand Rapids reveals several beach segments, higher than the well defined Grand Rapids 

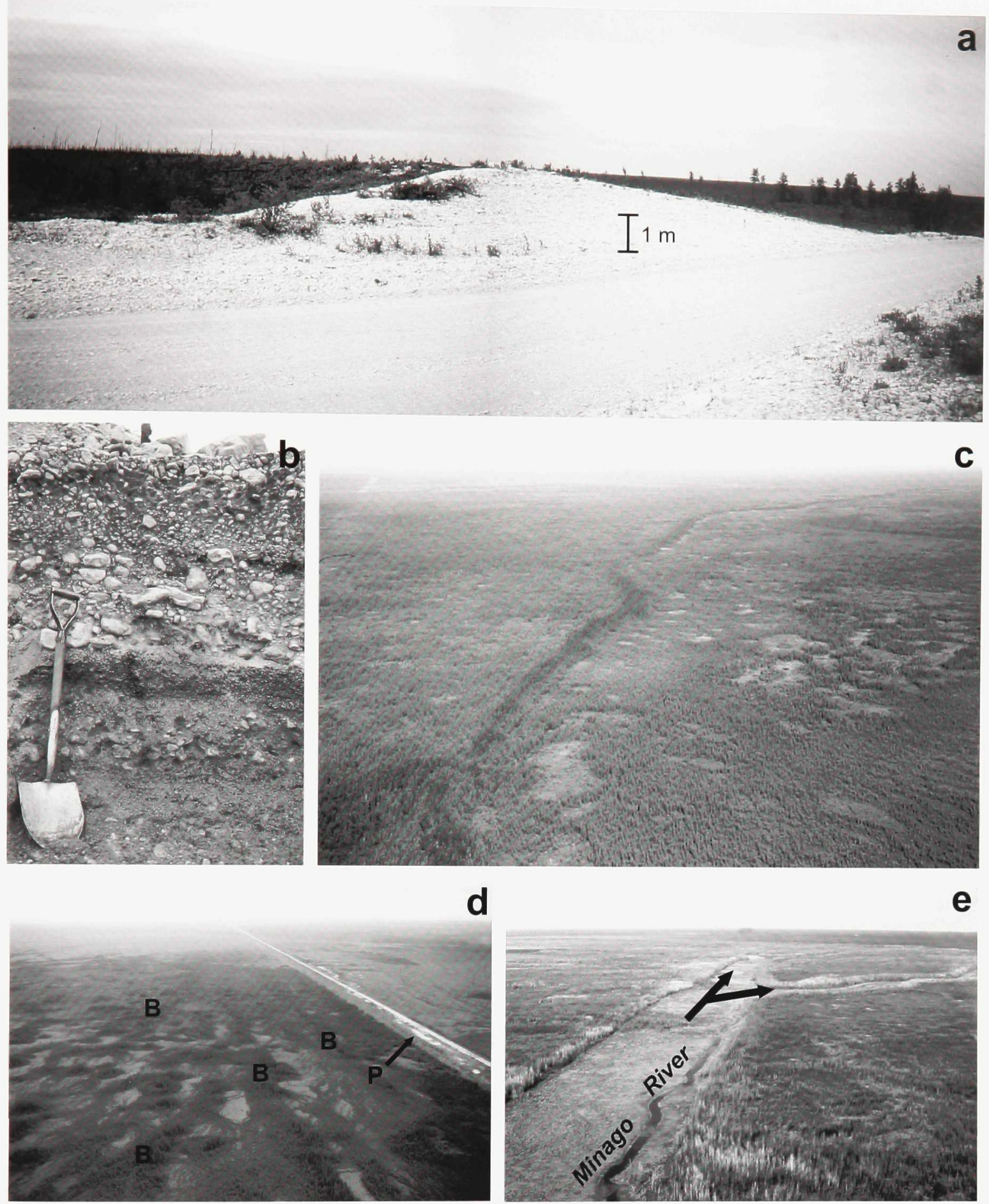

d

e

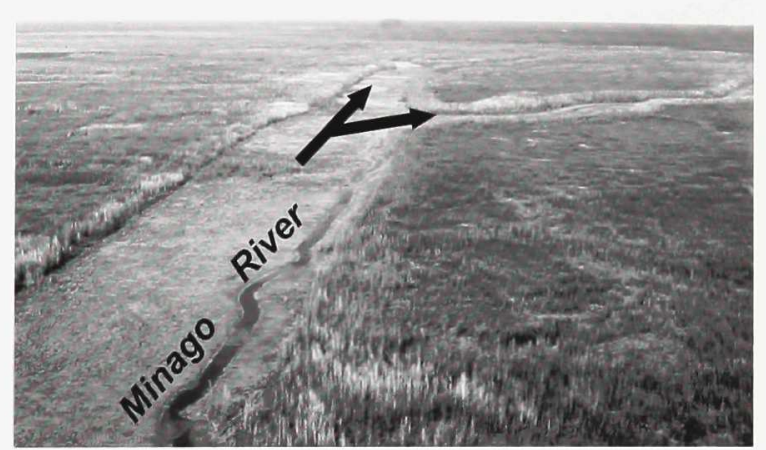

Figure 3.5 Photographs showing (a) coarse gravel beach ridge of the Gimli level across the Sturgeon Gill Creek road, (b) section in pebble beach of the Gimli shoreline south of Cormorant (shovel is $107 \mathrm{~cm}$ long), (c) Drunken Point beach ridge north of Hargrave River, (d) Ponton strandline (P) excavated for construction of Highway 6 and longshore bars (B) north of Minago River, and (e) Minago River channel where it splits temporarily into two arms around a bedrock plateau west of Highway 6 (channel is $300 \mathrm{~m}$ wide). 
strandline. Some beaches follow the $825^{\prime}$ contour $(251.5 \mathrm{~m})$ and at least one major ridge, now mostly excavated, is found at approximately $262 \mathrm{~m}$, based on the elevation of a nearby bench mark (Fig. 3.4c). Along the old portage tramway, now flooded behind the hydroelectric dam at 840' (256.1 m), Tyrrell (1917) reported a high beach at 850' (259.1 m) which was remeasured by Johnston (1946) at 869' (264.9 m). The highest beaches, at about 260$265 \mathrm{~m}$, probably pertain to the Gimli strandline, as postulated earlier by Johnston (1946).

\subsubsection{Grand Rapids}

In the Grand Rapids area, a major gravel beach that traverses the highway represents the Grand Rapids shoreline, as defined by Johnston (1946) (Fig. 3.4c). An altitude of 244.4 $\mathrm{m}$ is given by a bench mark that sits on top of a major segment of this beach ridge south of Saskatchewan River along Highway 6. The strandline continues north as it follows the Paleozoic bedrock escarpment west of Lake Winnipeg. In the Sturgeon Gill Creek road area, the Grand Rapids shoreline is part of a series of shingle beaches and is separated by two minor beach berms from the Drunken Point strandline (Fig. 3.4b). As many as three fairly continuous coarse gravel beaches and six minor beach berms occur between the Gimli and Grand Rapids strandlines in the same area. These berms are thought to represent either minor transitional shorelines formed during lake level lowering, or longshore bars. Where the escarpment traverses the highway towards the northwest north of William River, the Grand Rapids strandline is the lowest in the series of coarse gravel beaches at $263.0 \mathrm{~m}$ altitude. North of Minago River, the beaches are discontinuous and lose contact with the Silurian cliffs. In the Wekusko Lake area and farther north, only wave-washed bedrock hills 
are found, attesting to the lack of sediment supply for shoreline formation on shield terrain.

The Grand Rapids beaches were first documented by Tyrrell (1891) in the Grand Rapids area but named by Johnston (1946), and later briefly discussed by Klassen (1983) for the area northwest of Lake Winnipeg. Along the old portage tramway at Grand Rapids, Tyrrell (1891) observed three shorelines at elevations of 790', 800', and 805' (240.8, 243.9, and $245.4 \mathrm{~m}$ ). Johnston (1946) remeasured elevations of two of the same beaches at $809^{\prime}$ and 813' (246.6 and 247.9 m), which he correlated to the Grand Rapids series. Klassen (1983) correlated beach ridges to the Grand Rapids level, measured at 750' to 800' (228.7 to 243.9 m) near Grand Rapids, and between 875 and 900' (266.8 and 274.4 m) 50 km farther north. Mapping and elevation measurements reported here indicate that the beaches measured by Klassen in this area are part of three different levels, the Drunken Point, Grand Rapids and Gimli.

\subsubsection{Drunken Point}

Long segments of beach ridges occurring about $15 \mathrm{~m}$ below the Grand Rapids beaches are present for nearly $50 \mathrm{~km}$ north of Grand Rapids as they follow the base of the northward trending bedrock escarpment (Fig. 3.4b). Near Grand Rapids, the lowest of two major beaches above Lake Winnipeg has an approximate elevation of 760' (231.7 m), based on 1:50 000 scale topographic maps and surrounding bench mark data (Fig. 3.4c). The lowest of a series of gravel beaches across the bedrock escarpment traversing the Sturgeon Gill Creek road is at $235.9 \mathrm{~m}$ altitude (Fig. 3.4b). These are thought to be part of the 
Drunken Point shoreline, a level first named in published literature by Thorleifson (1996), although the name comes from the unpublished writings of J. Elson (Thorleifson, pers. comm., 1999). East of Little Limestone Lake, the strandline starts to diverge significantly from the escarpment and becomes low, sandy and discontinuous as it traverses marshy terrain with little topography. Immediately south of Minago River, segments of beaches are found on the northeast side of Silurian outliers whereas north of the river, the beaches associated with this level are inconspicuous and finally disappear in the rocky hills around Wekusko Lake. However, immediately north of Hargrave River, a broad and low plateau, thought to represent a buried portion of Hargrave Moraine (Tarnocai, 1970), is surrounded by a well defined beach ridge (Fig. 3.5c) that increases in elevation from 262.8 to $264.3 \mathrm{~m}$ towards the north.

The Drunken Point shoreline had never been clearly defined in the study area prior to this work. Elson (1967) reported a linear segment of a gravel beach about 16' above Lake Winnipeg near a point on Lake Winnipeg named Drunken Point (729' - 222.3 m). Teller and Thorleifson (1983) also reported a water plane immediately below the Grand Rapids based on Elson's work and miscorrelation with beaches measured by Bell (1978) north of Ponton.

\subsubsection{Ponton}

A distinct, north trending and continuous strandline has been identified and mapped in detail along Highway 6 south of Ponton (Fig. 3.3). The shoreline is continuous over large segments in the flat peatlands and occasionally splits into two low but well defined sandy 
beach ridges (Fig. 3.6a). Discontinuous features below the main ridges are interpreted as longshore bars (Fig. 3.5d). The two beaches converge into one along several linear low bedrock escarpments, forming a conspicuous single beach ridge of sand and gravel, or an erosional scarp. The beaches occur between $220 \mathrm{~m}$ and $271 \mathrm{~m}$ a.s.1., increasing in elevation towards the north. They merge into the present Lake Winnipeg shoreline and disappear in the lake (217.4 m altitude) about 10-15 km north-northeast of Grand Rapids.

Historically, measurements of the Ponton beaches, named by Bell (1978) but first described by Tyrrell (1917), have been complicated by the presence of two closely spaced levels $(<4 \mathrm{~m})$, and limited access prior to construction of Highway 6. Between William River and Minago River, the beaches merge into a well developed sandy berm that follows a gentle step in the carbonate bedrock for over $40 \mathrm{~km}$ southeast of Minago River (Fig. 3.6b). In the Minago River area, Ringrose (1975) traced the 'Minago beach' at the north end of the strandline described above, and measured the top of a $3.65 \mathrm{~m}$ high section of stratified sediments at $243.5 \mathrm{~m}$ (Fig. 3.6b). Mollusc shells (Lampsilis radiata) collected $3.19 \mathrm{~m}$ below the surface of this shoreline were radiocarbon dated at $8310 \pm 180{ }^{14} \mathrm{C}$ years (GSC-1679). In an effort to determine the magnitude of the hard-water effect in calcareous Saskatchewan River sediments of mid-Holocene age, McMartin (1999b) estimated a hard-water correction factor of about 380 years based on the difference in ${ }^{14} \mathrm{C}$ age between mollusc shells and limnic peat. Nielsen et al. (1987) have applied a correction factor of 350 years to freshwater shells collected in mid-Holocene Lake Winnipegosis beaches, based on an age obtained from a modern shell sample. Therefore, the radiocarbon date on the Minago shells is estimated 

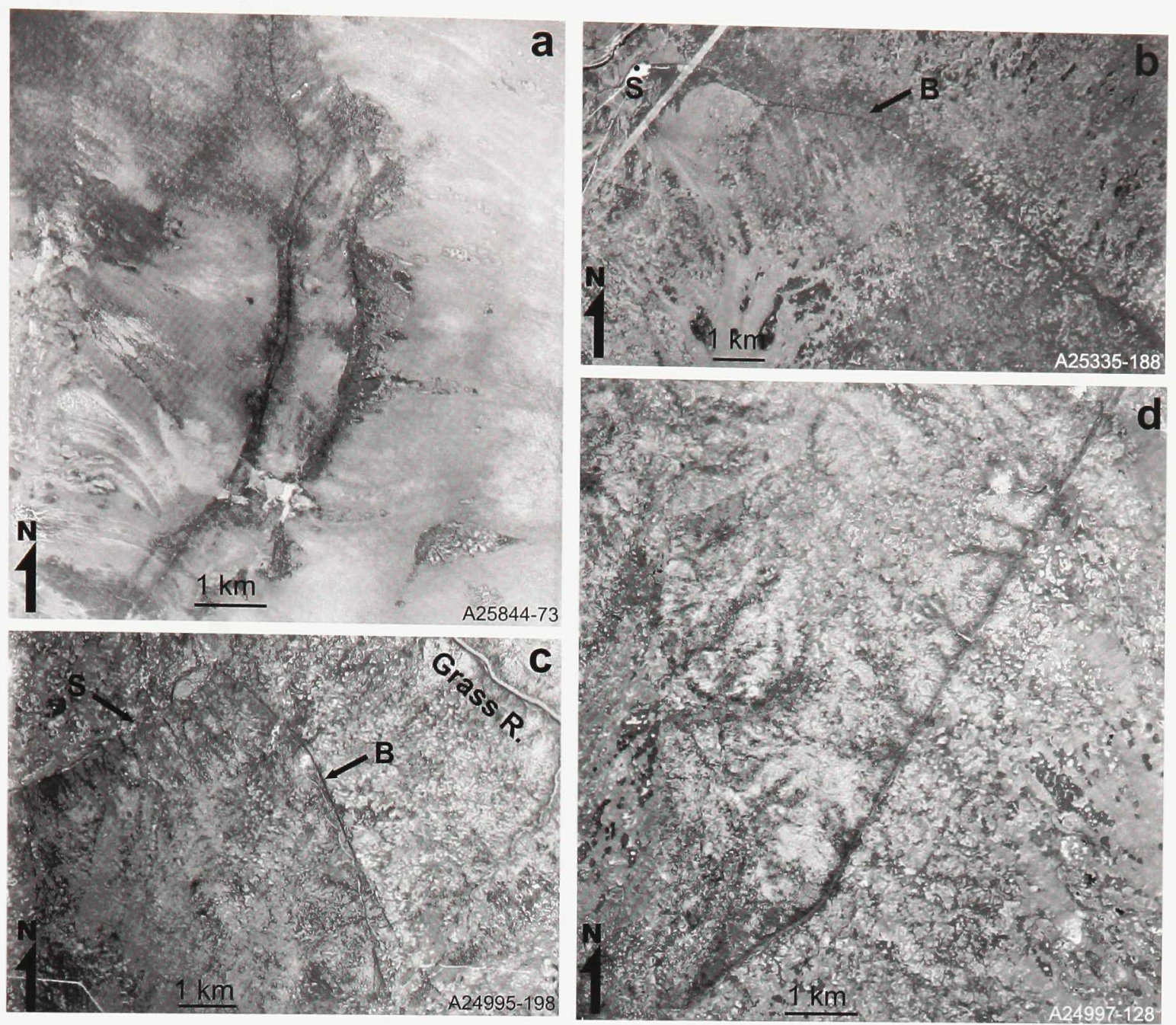

Figure 3.6 Aerial photographs of the Ponton strandline showing (a) where it splits into two low sandy beach ridges east of Little Limestone Lake, (b) beach ridge (B) along a carbonate bedrock escarpment southeast of Minago River and location of Minago River section (S) described by Ringrose (1975), (c) beach ridge (B) and wave-cut scarp (S) along the Paleozoic-Precambrian boundary north of Ponton, and (d) linear beach ridge developed along a low bedrock escarpment north of Davis Creek. 
to be about 400 years too old and the Ponton beach is believed to have formed about $7.9 \mathrm{ka}$ ${ }^{14} \mathrm{C} \mathrm{BP}$.

Tyrrell (1917) described the Ponton beaches at mile 109 of the railway, near the siding now known as Ponton (Fig. 3.2). While Tyrrell reported an altitude of 848' (258.5 m) for a strong beach at that site, Johnston (1919) identified another lower shoreline at 828' (252.4 m) but miscorrelated both beaches to the Grand Rapids level. Based on a highway survey, Bell (1978) obtained a precise elevation of 833' (253.9 m) for the upper shoreline near Ponton. An elevation of $251.7 \mathrm{~m}$ (similar to Johnston's) was recently obtained for the lower shoreline at the same site. North of Ponton, the two beaches merge again along the boundary between Paleozoic rocks and the Precambrian shield which is marked by a 3-5 m high escarpment (Fig. 3.6c). The top of the escarpment follows approximately the 850' contour $(259.1 \mathrm{~m})$ on 1:50 000 scale topographic maps. The shoreline consists of a beach berm commonly present near the base of the escarpment, or a wave-cut scarp. Its elevation is approximated at $255 \mathrm{~m}$, although Bell (1978) reported an elevation of 870' (265.2 m) for the strandline in the same area. From its observed western termination along this escarpment, the strandline is lost in the Precambrian rocky hills east of Wekusko Lake and can not be recognized by air photo interpretation.

Well defined beach segments reappear about $20 \mathrm{~km}$ north of Grass River, and become continuous north of Davis Creek for over $24 \mathrm{~km}$ along a possible post-glacial fault scarp (Ruffman et al., 1996)(Fig. 3.6d). The altimeter measured elevation of the beach ridge 
increases from $261.2 \mathrm{~m}$ at Davis Creek to $270.9 \mathrm{~m}$ near its northern extremity within the study area. Bell (1978) reported higher elevations for the same ridge, varying from 888' (270.7 m) near Davis Creek to 913' (278.3 m) farther north. On the basis of Bell's measurements, Thorleifson (1996) miscorrelated all strandlines north of Ponton to the Drunken Point level. Continuity between the beaches at Ponton and the strandlines occurring along the Paleozoic-Precambrian contact to the north indicates that these features are part of the Ponton strandline, as postulated by Bell (1978). However, Bell's approximate measurements were probably inaccurate, perhaps as much as $10 \mathrm{~m}$ off along the Shield margin north of Ponton, and up to $8 \mathrm{~m}$ on the linear scarp north of Davis Creek.

\subsection{Paleolake levels and tilt history}

Correlation of paleo-shorelines by air photo interpretation revealed six major and near-parallel levels of Lake Agassiz (Fig. 3.7a-f). Lake levels were interpreted along each shoreline feature, and traced over 1:50 000 topographic maps. All continuous strandline segments showed an increase in elevation towards the north. Therefore, where shoreline evidence was lacking, the water planes were extrapolated to intersect topography (1:50 000 contour maps) and elevations estimated from a strandline diagram (Fig. 3.8). The strandline diagram was built first by tracing lines of equal post-glacial uplift at $25 \mathrm{~km}$ intervals over the study area (Fig. 3.3), using the northwest orientation of Lake Agassiz isobases 7, 8 and 9 $\left(304^{\circ}\right)$ from Teller and Thorleifson (1983) (Fig. 3.1), and by plotting the elevation of the strandlines with reference to these isolines. These isobases were originally defined by Johnston (1946) on the Upper Campbell shoreline south of isobase 6. Regional isobases 


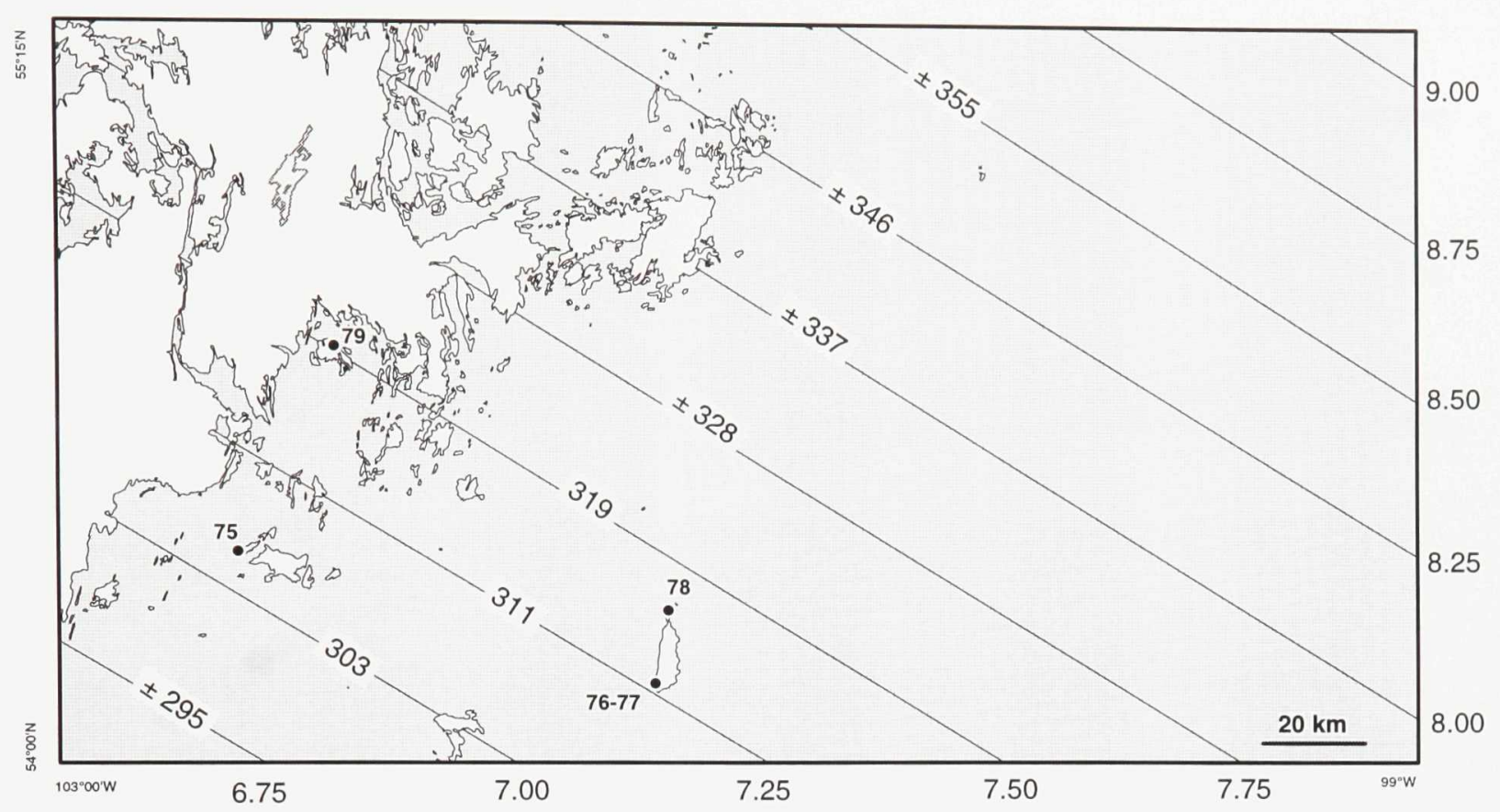

Figure 3.7 Paleogeography of Lake Agassiz reconstructed from strandline elevations and Lake Agassiz isobases oriented northwesterly at $304^{\circ}$. Elevations are shown in meters along each isoline; approximate elevations ( \pm ) are assumed where no strandlines were measured in between two isolines. White areas represent emerged lands during each level; an outline of modern hydrography is shown in dark grey over emerged lands (see Fig. 3.2 for location). Numbers refer to strandline elevations given in Table 3.1.

(a) Lake Agassiz configuration during the Stonewall level (Area 1, Fig. 3.2). The area south of latitude $54^{\circ}$ and east of longitude $99^{\circ}$ is not shown here as it was submerged completely during this level. 


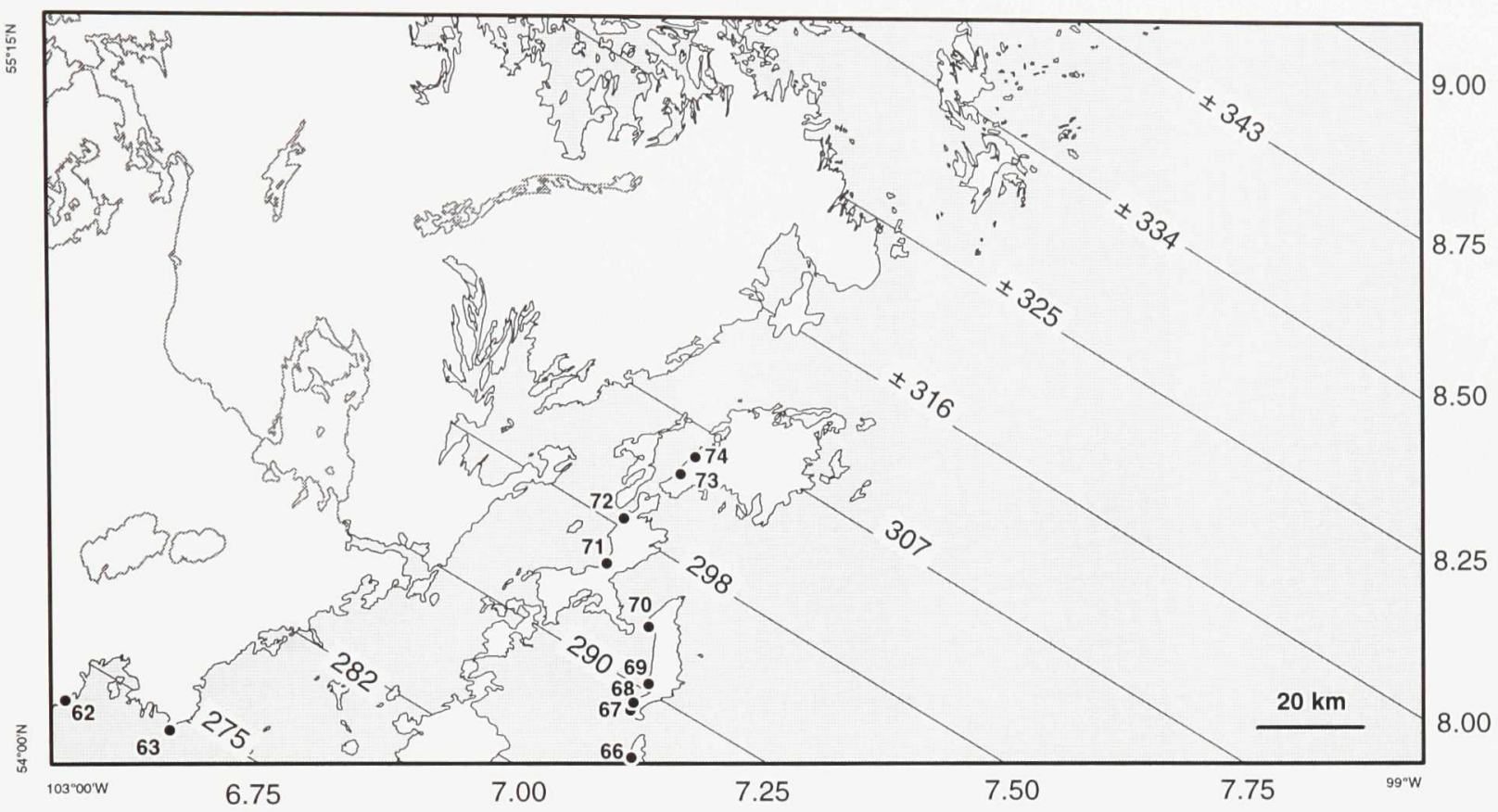

(b) Lake Agassiz configuration during The Pas level (Area 1, Fig. 3.2). The area south of latitude $54^{\circ}$ and east of longitude $99^{\circ}$ is not shown here as it was submerged completely during this level. 


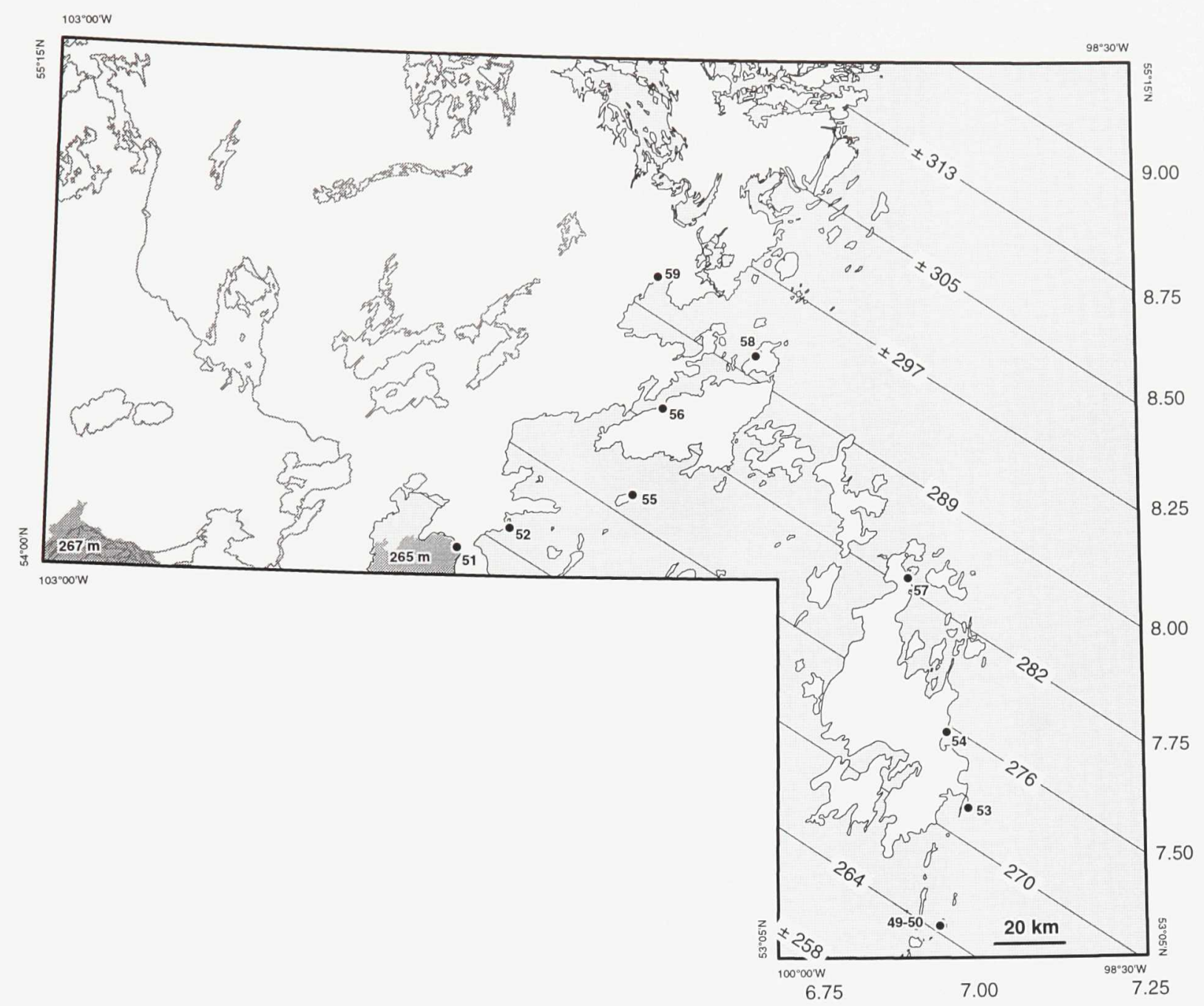

(c) Lake Agassiz configuration during the Gimli level. Dark shaded areas show the modern configuration and altitude of Saskatchewan River floodplain and deltaic sediments that probably started or continued deposition in Lake Agassiz west of The Pas Moraine during this level. 


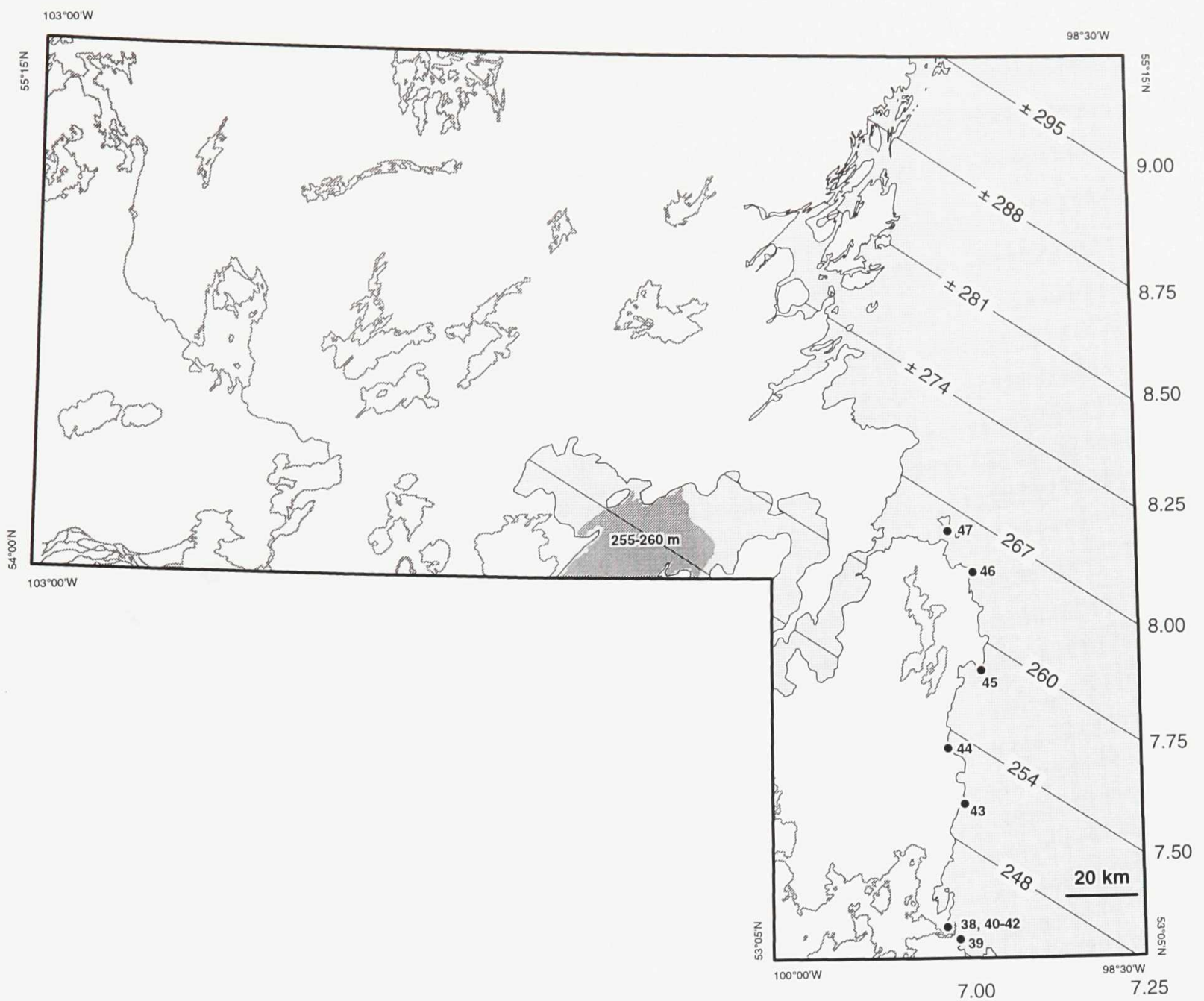

(d) Lake Agassiz configuration during the Grand Rapids level. During this level, the Saskatchewan River started to deposit deltaic sediments in Lake Agassiz west of North Moose Lake, and flowed to the northeast through the South Moose Lake area, by-passing the Lake Winnipeg area. 


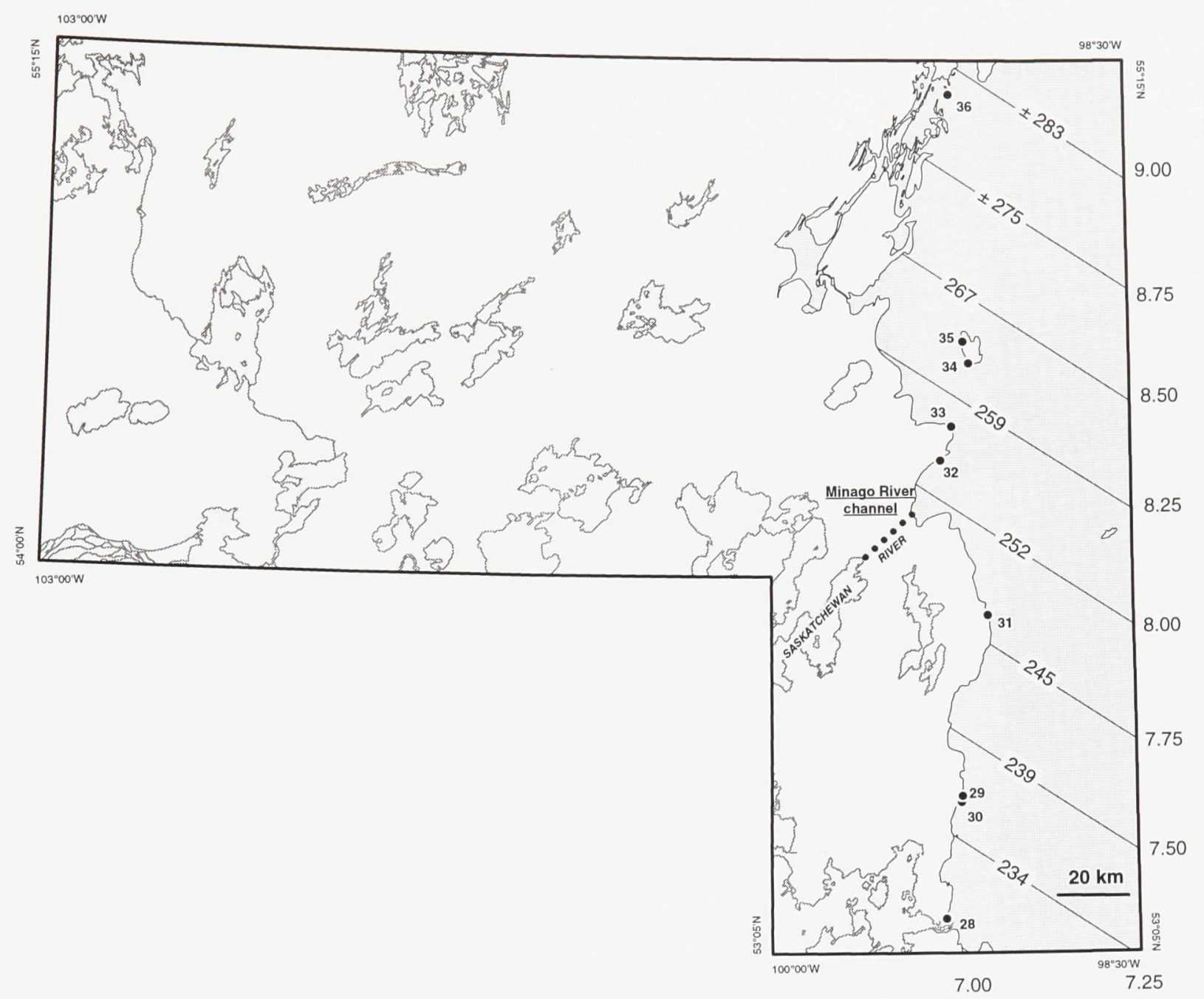

(e) Lake Agassiz configuration during the Drunken Point level. The Saskatchewan River entered Lake Agassiz via the upper reaches of the Minago River channel, still by-passing the Grand Rapids area. 


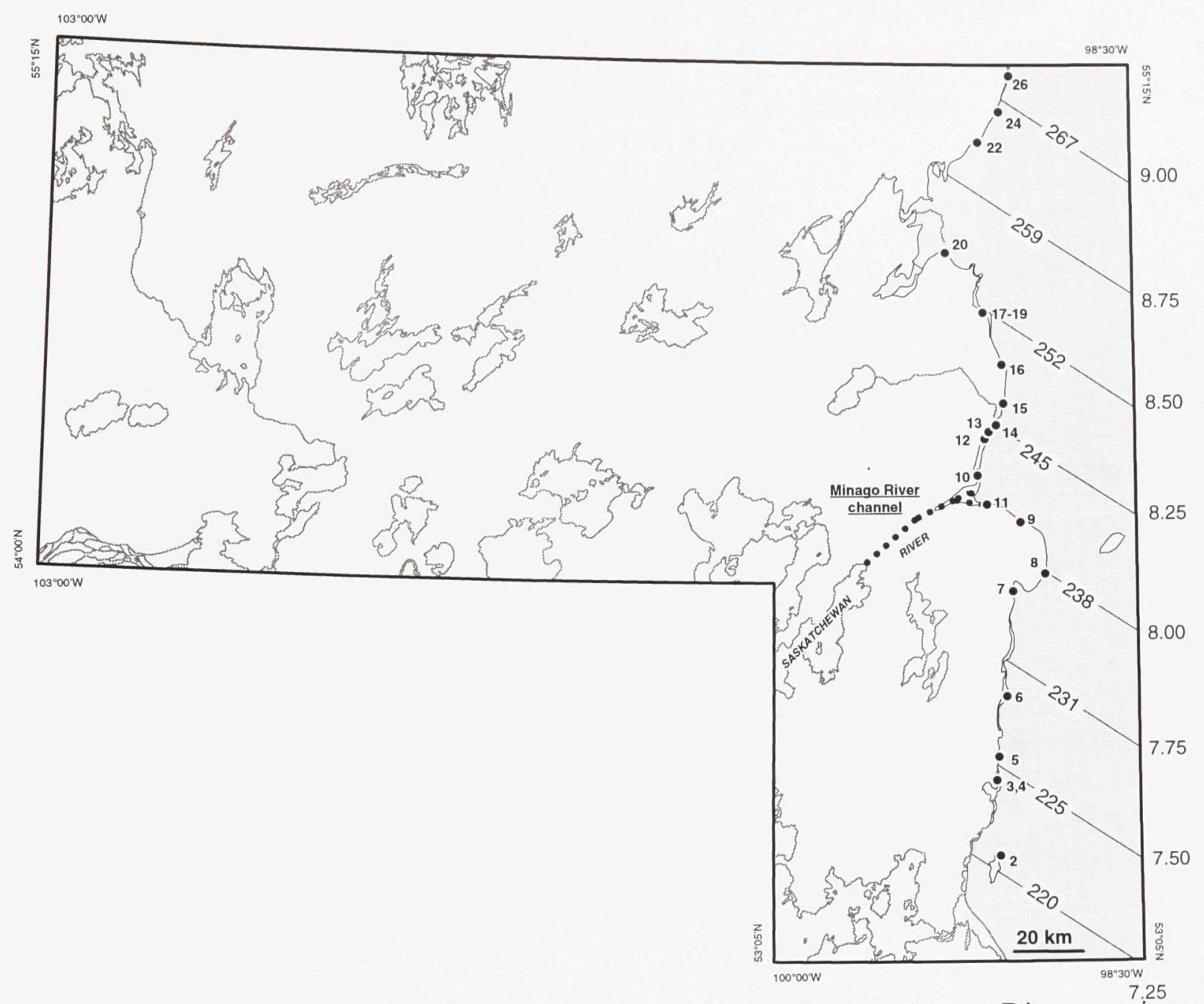

(f) Lake Agassiz configuration during the Ponton levels. The Saskatchewan River continued to enter Lake Agassiz through the Minago River channel, which then extended over $50 \mathrm{~km}$ northeast of South Moose Lake. The two closely spaced Ponton levels are depicted here but only the elevations of the lower one are shown on each isoline. 


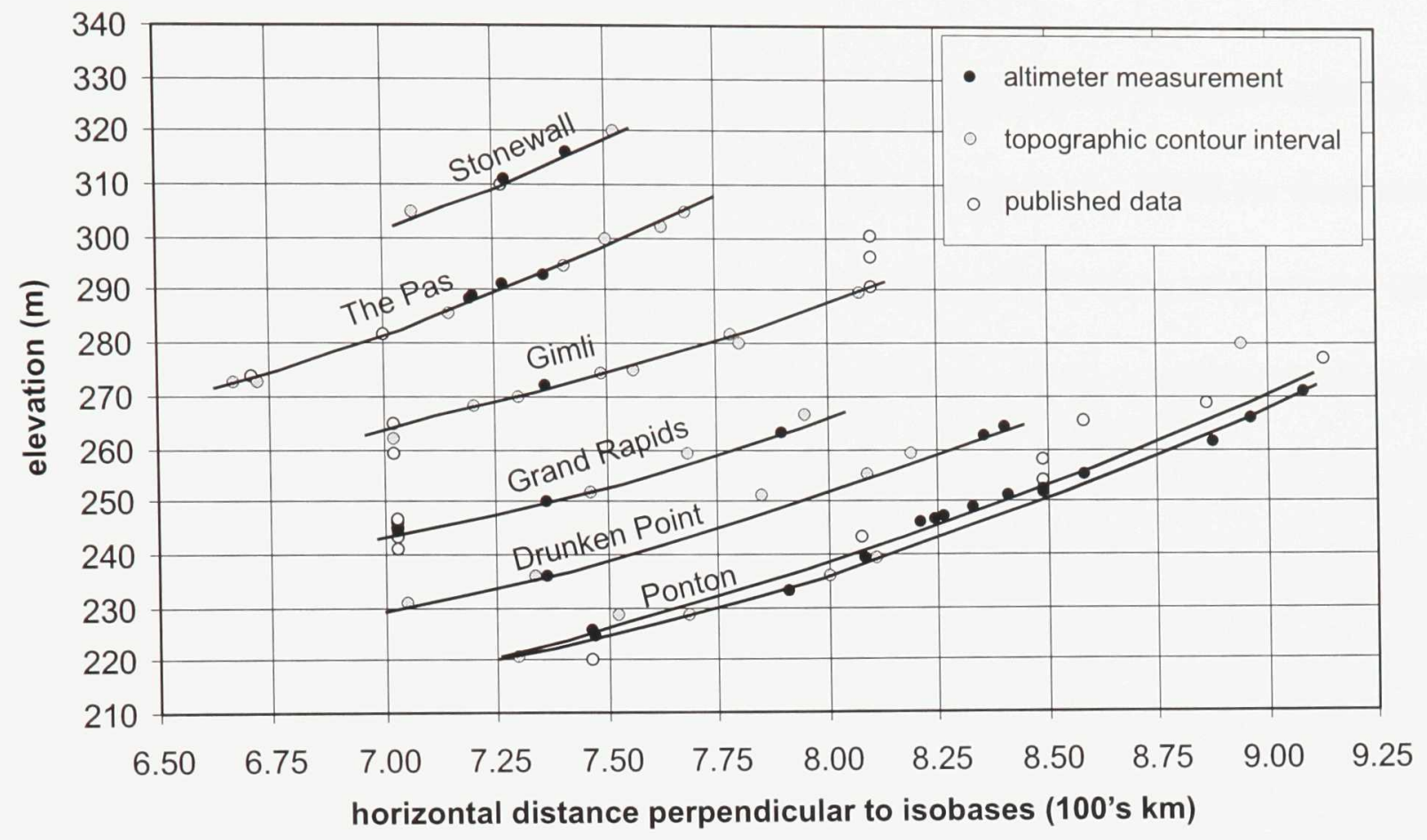

Figure 3.8 Plot of strandline elevations from Table 3.1 with reference to lines of equal post-glacial uplift, and interpreted lake levels. Differential uplift of the paleo-water planes decreases from $0.34 \mathrm{~m} / \mathrm{km}$ for the Stonewall level to approximately $0.22 \mathrm{~m} / \mathrm{km}$ for the Ponton level between isobases 7 and 8 . Between isobases 8 and 9 , the average gradient decreases from $0.31 \mathrm{~m} / \mathrm{km}$ to 0.29 $\mathrm{m} / \mathrm{km}$ from the Drunken Point to the Ponton level. 
plotted by Dyke (1996) at 9 and $8 \mathrm{ka}{ }^{14} \mathrm{C} \mathrm{BP}$ for the continental interior (approximately $310^{\circ}$ and $320^{\circ}$ respectively), and isobases determined by Tackman et al. (1998) for the Burnside level of Lake Agassiz immediately south of the study area $\left(303^{\circ}\right)$, have orientations similar to those of Teller and Thorleifson (1983). Because most of the continuous strandlines documented here have a northerly trend, and data is lacking on the eastern side of the lake basin (east of Lake Winnipeg), it was not possible to refine the regional northwesterly oriented isobases used to construct the strandline diagram.

\subsubsection{Stonewall level}

The highest level reconstructed here is based on the measurement of the highest most continuous beach ridge present on the crest of The Pas Moraine east of Wanless (Fig. 3.7a). Higher levels such as the Ossowa and the Burnside probably did exist prior to the Stonewall level in the northwestern part of the area as a complex of islands and shoals. During the Stonewall level, the higher reaches of The Pas Moraine formed a large island in the study area. Most of the Paleozoic terrain was submerged under Lake Agassiz, with the exception of a few high plateaus and drumlins, and higher ground west of Amisk Lake. On the Shield, a long re-entrant along the Sturgeon-Weir River probably connected with Lake Agassiz waters also covering the Mirond Lake-Pelican Narrows area. During this level, if the ice margin stood up-ice from the study area as discussed below, water depths exceeded $110 \mathrm{~m}$ over the thick glaciolacustrine belt in the centre of the Grass River Basin.

An average gradient of approximately $0.32 \mathrm{~m} \mathrm{~km}^{-1}$ was obtained on the highest 
shoreline around The Pas Moraine (isobase 7-7.5). However, this is based on only two precise measurements and therefore, the measured tilt can only represent an approximation of the differential uplift in the area. Previous authors have shown similar gradients for this water plane, from about $0.35 \mathrm{~m} \mathrm{~km}^{-1}$ (isobase 5-6) in southern Manitoba (Johnston, 1946: 3 , Fig. 2) to $0.25 \mathrm{~m} \mathrm{~km}^{-1}$ at isobase 5 to 7 (1.3 feet mile ${ }^{-1}$, Elson, 1967). Northeast of isobase 7.5 , there is no data on the Stonewall level and the gradient of the water plane was assumed to have a constant upward tilt of $0.36 \mathrm{~m} \mathrm{~km}^{-1}$ towards the northeast.

\subsubsection{The Pas level}

Lake Agassiz dropped about $20 \mathrm{~m}$ from the Stonewall level before it stabilized at The Pas level (Fig. 3.7b). North and south of The Pas, the shoreline skirted around segments of The Pas Moraine. Elsewhere on Paleozoic terrane, it was defined by large plateaus of till and dolomitic bedrock. Southwest of the study area, the Saskatchewan River entering Lake Agassiz formed a large delta (Elson, 1967; Schreiner, 1983) and probably deposited distal turbidity current deposits over the study area west of Cumberland Lake. During this phase, water depths rarely exceeded $35 \mathrm{~m}$ over the submerged Paleozoic cover and $50 \mathrm{~m}$ over the Shield, with the exception of the Grass River Basin where its middle portion was under more than $90 \mathrm{~m}$ of water.

A gradient averaging $0.32 \mathrm{~m} \mathrm{~km}^{-1}$ between isobases 6.75 and 7.75 was obtained for The Pas level. This gradient is significantly higher than those presented for this level by Johnston (1946, $0.1 \mathrm{~m} \mathrm{~km}^{-1}$ ) and Elson (1967, $0.15 \mathrm{~m} \mathrm{~km}^{-1}$ ), but lower than that suggested 
by Klassen $\left(1983,0.6 \mathrm{~m} \mathrm{~km}^{-1}\right)$ on a lake level at $9.0 \mathrm{ka} \mathrm{BP}$, which he thought represented The Pas level in northern Manitoba. Over the Shield, a constant upward tilt of $0.36 \mathrm{~m} \mathrm{~km}^{-1}$ was assumed north of isobase 8 .

\subsubsection{Gimli level}

Lake Agassiz fell another 20-25 m from The Pas level before it formed the Gimli shoreline (Fig. 3.7c). It is assumed that the beach elevation measured by Johnston (1946) at Grand Rapids is the most accurate elevation reported from the literature in this area (Table 3.1, No. 50) since Tackman et al. (1998) have shown that elevations of Lake Agassiz strandlines given by Johnston (1946) were always within one vertical foot of their recent high-precision survey. North of Grand Rapids, large islands defined by dolomitic plateaus shaped the shoreline during this level. The Saskatchewan River entered Lake Agassiz west of The Pas and continued to form a large delta that probably extended into the Root Lake area at $265 \mathrm{~m}$ altitude. In the Grass River Basin, water depths exceeded $60 \mathrm{~m}$ over the middle part of the thick glaciolacustrine belt.

The gradient of the Gimli beaches increases from 0.24 to $0.28 \mathrm{~m} \mathrm{~km}^{-1}$ towards the northeast with an average of $0.25 \mathrm{~m} \mathrm{~km}^{-1}$ between isobases 7 and 8 . The average regional tilt is significantly higher than the one shown by Johnston $\left(1946,0.07 \mathrm{~m} \mathrm{~km}^{-1}\right)$ for the area north of Grand Rapids, and the one reported by Elson $\left(1967,1.8\right.$ feet mile $\left.{ }^{-1}=0.15 \mathrm{~m} \mathrm{~km}^{-1}\right)$. North of isobase 8 , the lake level was assumed to have a constant upward tilt of $0.32 \mathrm{~m} \mathrm{~km}^{-1}$ to the northeast. 


\subsubsection{Grand Rapids level}

Lake Agassiz dropped about $20 \mathrm{~m}$ from the Gimli level to form the Grand Rapids shoreline (Fig. 3.7d). During this phase, the Saskatchewan River entered Lake Agassiz through the South Moose Lake area as supported by the dissection of the Grand Rapids strandline at the present river mouth near Grand Rapids (Fig. 3.4c). A delta started to form west of North Moose Lake, where the present surface of abandoned floodplain and deltaic sediments is at $255-260 \mathrm{~m}$ altitude. On the Shield, Precambrian rolling hills formed an archipelago of islands where longshore drift and fetch were not sufficient to form any significant beach ridges. During this phase, the Grass River Basin was a relatively flat basin with waters approaching $30 \mathrm{~m}$ depth over large parts of the study area, and exceeding $40 \mathrm{~m}$ in the middle of the thick glaciolacustrine belt.

The gradient on this level varies from 0.20 to $0.28 \mathrm{~m} \mathrm{~km}^{-1}$ between isobases 7 and 8 , averaging $0.24 \mathrm{~m} \mathrm{~km}^{-1}$. Again, this is significantly higher than what Johnston (1946, 0.07 $\mathrm{m} \mathrm{km}^{-1}$ ) presented for the area north of Grand Rapids, as he misinterpreted the Ponton beaches for the Grand Rapids beaches near Ponton. Klassen (1983) recorded a substantially higher gradient at $0.5 \mathrm{~m} \mathrm{~km}^{-1}$, but he miscorrelated the upper flight of shingle beaches $50 \mathrm{~km}$ north of Grand Rapids (Gimli) to the Grand Rapids beaches. North of isobase 8, the lake level was assumed to follow a constant gradient of $0.28 \mathrm{~m} \mathrm{~km}^{-1}$.

\subsubsection{Drunken Point level}

Lake Agassiz fell about $15 \mathrm{~m}$ from the Grand Rapids level prior to stabilizing at the 
Drunken Point shoreline (Fig. 3.7e). Around this time, the Saskatchewan River started to flow through the Minago River channel (McMartin, 1996, 1999b), bypassing the Lake Winnipeg area, as suggested by the dissection of the Drunken Point strandline at Grand Rapids by the modern Saskatchewan River (Fig. 3.4c). The abandoned channel consists of a series of lakes and a valley presently occupied by the Minago River, between South Moose Lake and the Nelson River (Fig. 3.5e). It is about $400 \mathrm{~m}$ wide, up to $100 \mathrm{~km}$ long, and was excavated in about $20 \mathrm{~m}$ of glaciolacustrine fine grained sediments. Farther north, Lake Agassiz covered the area of Wekusko Lake, and the shoreline formed a complex lake configuration north of Grass River. Lake depths during this level exceeded only $25 \mathrm{~m}$ in the middle of the fine grained sedimentation basin.

The gradient of this level increases from $0.20 \mathrm{~m} \mathrm{~km}^{-1}$ north of Grand Rapids to 0.30 $\mathrm{m} \mathrm{km}^{-1}$ east of Hargrave Lake. On his Lake Agassiz strandline diagram, Thorleifson (1996) presented a tilt of about $0.17 \mathrm{~m} \mathrm{~km}^{-1}$ for this level, increasing to only about $0.23 \mathrm{~m} \mathrm{~km}^{-1}$ between isobases 8 and 9 , as he miscorrelated the beaches north of Ponton, inaccurately measured by Bell (1978), with the Drunken Point level. North of isobase 8.5, the lake level was assumed to have a constant tilt of $0.32 \mathrm{~m} \mathrm{~km}^{-1}$.

\subsubsection{Ponton level}

The Ponton level is the lowest lake level reconstructed here (Fig. 3.7f). The continuity of the Ponton beaches and the abundance of elevation points along the easily accessible ridges from Highway 6 make the water plane better defined than for the previous 
levels. Lake Agassiz dropped about $15 \mathrm{~m}$ from the Drunken Point level to form the upper Ponton shoreline, and fell further 2-3 m before it stabilized at the lower Ponton level probably due to outlet erosion. In the Grand Rapids area, the shoreline approximately trended to the south-southeast, at or a few meters below the present Lake Winnipeg shoreline. North of Grand Rapids, the shoreline trended northward to the Minago River area, where the Saskatchewan River continued to enter Lake Agassiz via the Minago River channel. The shoreline continued to the north until it reached the Precambrian-Paleozoic boundary, and followed the edge of higher Precambrian bedrock hills in the Grass River area. The Grass River Basin had started to emerge significantly during the Ponton level and Lake Agassiz was no more than $10-15 \mathrm{~m}$ deep over the glaciolacustrine belt.

This study shows that the Ponton beaches are tilted up towards the northeast, at about $0.20 \mathrm{~m} \mathrm{~km}^{-1}$ near Grand Rapids and up to $0.29 \mathrm{~m} \mathrm{~km}^{-1}$ between isobases 8 and 9 . These tilt figures are higher than those inferred by Klassen $\left(1983,0.2 \mathrm{~m} \mathrm{~km}^{-1}\right)$, by Ringrose (1975, 0.2 $\mathrm{m} \mathrm{km}^{-1}$ ) for the corresponding Minago beaches, and by Thorleifson (1996, 0.15 to $0.25 \mathrm{~m} \mathrm{~km}$ ${ }^{1}$ ) in between isobases 7 and 9 .

\subsubsection{Lower levels}

Reconnaissance examination of air photos for the area immediately south of Setting Lake reveals the occurrence of several beach ridges developed on the slopes of ice contact sand and gravel deposits that follow the 800' contour line ( $243.9 \mathrm{~m}), 15 \mathrm{~m}$ below the Ponton beaches. Numerous well defined beaches also occur around other ice contact ridges and 
terraces south of Kiskitto Lake and east of the study area between $730^{\prime}$ and $750^{\prime}$ (222.6 to $228.7 \mathrm{~m}$ ). These may correlate to the beaches near Setting Lake as they also occur 15 to 20 m below the Ponton beaches. Tyrrell (1917) was the first to report a gravel ridge at mile 127 of the railway northeast of The Pas near the railway siding named Pipun (Fig. 3.2). It was reported to him "by the chief engineer as occurring a few miles to one side of the right of way" (p. 147) at $805^{\prime}(245.4 \mathrm{~m})$. Although the Setting Lake beaches represent the lowest Lake Agassiz beaches recognized in the study area, their scarcity and discontinuity prevent any paleogeographic lake reconstruction. Elson (1967) shows a tilt of about $0.06 \mathrm{~m} \mathrm{~km}^{-1}$ for a Pipun level on his Lake Agassiz strandline diagram, apparently using the shoreline occurrence at Pipun and undocumented beach ridges. He also reconstructed the Pipun phase at 7.5 ka BP, showing essentially the Ponton level in the study area (Elson, 1967). Grice (1970) obtained a tilt of $0.05 \mathrm{~m} \mathrm{~km}^{-1}$ on this "Pipun level" when he miscorrelated the beaches behind the present shoreline of Lake Winnipeg in the Grand Rapids area (Ponton) with the beaches at Pipun. More likely, if the beaches south of Kiskitto Lake are correlated to the ones near Setting Lake, the isostatic tilt on this level, referred here as the Setting level, is about $0.28 \mathrm{~m} \mathrm{~km}^{-1}$ between isobases 8 and 9. During this level, Lake Agassiz may have extended to the area now occupied by the northern shore of Lake Winnipeg, disappearing somewhere in the north basin, as suggested by Lewis and Todd (1996).

Klassen (1983) reported another beach, the Fidler, at $250 \mathrm{~m}$ along the Northern Indian Moraine, $200 \mathrm{~km}$ to the north (approximately isobase 11). From this, he estimated a differential uplift of $0.3 \mathrm{~m} \mathrm{~km}^{-1}$ for the strandline in this area. Both Klassen (1983) and 
Thorleifson (1996) have shown the Fidler level extending along the northwestern shore of Lake Winnipeg within the study area. However, no beaches are found between Lake Winnipeg and the Ponton beaches. With an approximate tilt of $0.2 \mathrm{~m} \mathrm{~km}^{-1}$, as shown by Thorleifson (1996) in his strandline diagram between isobases 9 and 11, the Fidler level north of Grand Rapids would fall below the present altitude of Lake Winnipeg (217.4 m), hence Lake Agassiz would not have extended to the northern basin of Lake Winnipeg.

\subsection{Discussion}

Beaches form under specific conditions, including a steady supply of material to the shoreline, moderate to high wave energy, and a moderately stable, low gradient nearshore slope (Chorley et al., 1984). Hence, depositional shoreline features are frequently discontinuous along the shores of a lake. In ancient pro-glacial lake basins, the lack of continuity between shoreline features can be increased due to post-depositional processes such as fluvial reworking and mass wasting. However, detailed mapping of Lake Agassiz strandlines and re-evaluation of published information for the Flin Flon region have enabled the correlation of these discontinuous features. Correlation was mainly successful along The Pas Moraine and within the Grass River Basin, where thick sediments provided a steady supply of material for shoreline development.

Long-term lake level changes reflect an integrated response to climate, crustal movement, drainage rearrangement and outlet incision. Under a constant climate, the level of an overflowing lake is fixed by the elevation and geometry of its outlet. In pro-glacial 
lakes the shoreline terminates at the ice margin and as such when the ice front retreats, the lake expands; but as lower outlets are freed, the lake level also lowers. The succession of near-parallel Lake Agassiz strandlines documented in the Flin Flon region records a series of step-wise falling lake levels where each major change in lake level formed a corresponding shoreline. Elevation measurements have also shown that the once-level shorelines of Lake Agassiz are now tilted and deformed. Therefore, the paleogeography of Lake Agassiz was predominantly controlled by the position of the ice margin relative to the outlets, and glacio-isostatic rebound, as indicated by the location of the shorelines and their degree of differential uplift.

\subsubsection{Ice marginal positions and timing of shorelines}

Ice marginal positions in contact with the late phases of Lake Agassiz have been discussed by Christiansen (1979), Schreiner (1983), Klassen (1983), Dredge (1983) and Thorleifson (1996). However, very few ages are available to constrain the absolute chronology of deglaciation. This results in marked differences amongst authors on moraine correlations and timing of ice marginal positions. Although precise dating of Lake Agassiz shorelines remains difficult because of the lack of organic material suitable for ${ }^{14} \mathrm{C}$ dating in the coarse beach sediments, the position of the shorelines relative to ice margins and outlets can indicate a relative chronology that further constrains the deglaciation models.

According to Teller and Thorleifson (1983), following the retreat of the ice margin from the Sioux Lookout and Nipigon Moraines in Ontario, several outlets that carried 
overflow from the Lake Agassiz basin east to the Atlantic Ocean were opened, and the southern outlet to the Gulf of Mexico was definitively abandoned (cf. Fig. 3.1), initiating the Nipigon Phase at circa 9.5 ka BP (Thorleifson and Kristjansson, 1993: 9.1 ka). By about 8.5 ka BP (Thorleifson, 1996: $8.0 \mathrm{ka}$ ), ice had retreated far enough north to allow overflow directly into Lake Ojibway, completely by-passing the Great Lakes. These late Lake Agassiz phases, which Thorleifson (1996) regrouped into the Morris Phase, were characterized by continued ice retreat, and the opening of successively lower outlets, culminating in final drainage into the Tyrrell Sea by about $7.5 \mathrm{ka}{ }^{14} \mathrm{C}$ BP. The eastern outlets to Lake Nipigon have been described earlier by Elson (1957), Zoltai (1967) and Teller and Thorleifson (1983). They are located about $800 \mathrm{~km}$ southeast of the study area between isobases 7 and 9 in the Teller and Thorleifson system, similar to the Flin Flon region (Fig. 3.1). Additional possible outlets directly to Lake Superior have been recently proposed by Thorleifson (1996). Other probable connections to Lake Ojibway and possibly to early Hudson Bay through subglacial channels are poorly known and described (Dredge, 1983; Klassen, 1983; Thorleifson, 1996). Figure 3.9 shows the elevation of the eastern outlets with respect to the isobases as recently proposed by Thorleifson (1996), superposed by the newly interpreted levels for the Flin Flon region.

The Stonewall, The Pas and Gimli shorelines likely formed as Lake Agassiz discharged to the Atlantic Ocean through the eastern outlets near Lake Nipigon, apparently through the Pikitigushi System (Fig. 3.9), as proposed earlier by Elson (1967) and Teller and Thorleifson (1983). The Stonewall level probably occurred between $8.6 \mathrm{ka}$ BP and $8.3 \mathrm{ka}$ 


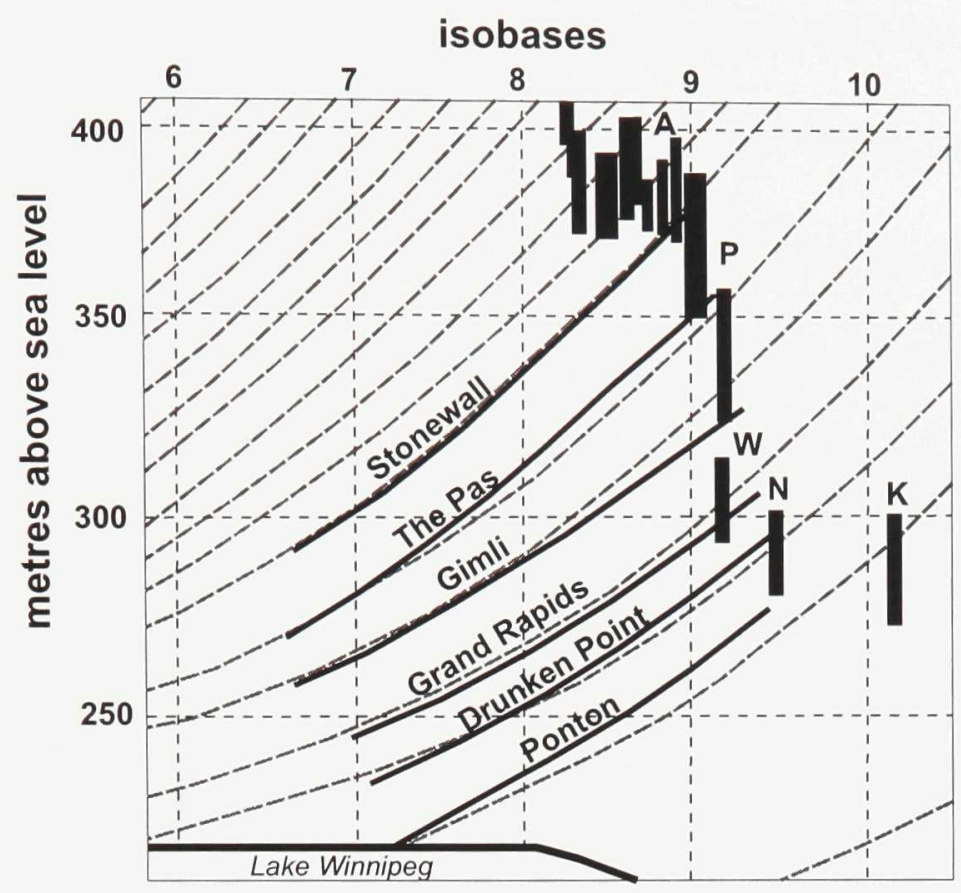

Figure 3.9 Lake Agassiz strandline diagram showing former water planes (dashed) and outlets (vertical bars) projected onto a vertical plane orthogonal to the isobases (modified from Thorleifson, 1996). Superposed are the six water planes interpreted from strandlines measured in this study. Outlet systems are named as follows: 1) Lake Nipigon outlets, Armstrong (A) and Pikitigushi (P), 2) Lake Superior outlets, White Otter (W) and Nagagami (N), and 3) outlet to Lake Ojibway, Kinojévis (K). 
BP, based on eastern outlet chronology tied to the position and timing of moraines near Lake Nipigon (Elson, 1967; Teller and Thorleifson, 1983). While Elson (1967) showed an approximate ice frontal position at the Sipiwesk Moraine during the Stonewall level at 8.3 ka BP, Thorleifson (1996) suggested that the ice front must have been at an undetermined position between The Pas and Hargrave Moraines at approximately the same age. Thorleifson's chronology for the Morris Phase reflects in part the assumed age of $9.3 \mathrm{ka} \mathrm{BP}$ for The Pas Moraine, about 1500 years younger than the models of Christiansen (1979) and Dyke and Prest (1987b), and the age of $8.2 \mathrm{ka}$ BP for the Agutua Moraine, from which ice retreat permitted a connection to Lake Ojibway. In any case, the recognition of Stonewall strandlines on the crest of The Pas Moraine in the Wanless area confirms that Lake Agassiz had fallen to the Stonewall level after the ice had retreated from the moraine, most probably later than $9.3 \mathrm{ka} \mathrm{BP}$, and before $8.2 \mathrm{ka} \mathrm{BP}$.

Thorleifson (1996) positioned the ice front at the Hargrave Moraine during The Pas/Gimli level, at circa $8.2 \mathrm{ka} \mathrm{BP}$, whereas Elson (1967) reconstructed the Gimli level at circa $8.0 \mathrm{ka}$ BP and speculated an ice marginal position $50 \mathrm{~km}$ up-ice from Sipiwesk Moraine, about $150 \mathrm{~km}$ from Lake Winnipeg. The position of the thick glaciolacustrine sediments relative to the configuration of the lake levels indicates that most of the deep water (>20 m) fine grained sedimentation had been completed when Lake Agassiz fell to the Gimli level (Fig. 3.7c). On the other hand, Antevs (1931) counted 400 varves in the Wekusko Lake area immediately west of the approximate position of the Hargrave moraine, suggesting that the ice margin stood at this moraine at least 400 years prior to the Gimli level. Hence during 
The Pas/Gimli levels, the ice front stood further up-ice from the Hargrave Moraine, during which time glacial meltwaters continued to deposit fine grained glaciolacustrine sediments in the thick belt, completely hiding the morphologic surface expression of the Hargrave Moraine. If the age of $8.2 \mathrm{ka} \mathrm{BP}$ for The Pas/Gimli level is correct, then the ice front was possibly positioned at the Hargrave Moraine at circa $8.6 \mathrm{ka} \mathrm{BP}$. Therefore, during the Stonewall level at approximately $8.3 \mathrm{ka} \mathrm{BP}$, the ice margin may have stood at the Sipiwesk Moraine, or farther up-ice.

The Gimli level was the lowest beach formed by Lake Agassiz when it overflowed into Lake Superior via the Nipigon basin (Teller and Thorleifson, 1983; Teller, 1985). As ice retreated in Ontario, Lake Agassiz discharge was perhaps diverted to outlets directly entering Lake Superior during the Grand Rapids/Drunken Point levels (Fig. 3.9), as suggested by Thorleifson (1996). Klassen (1983) depicted a lake configuration thought to represent the Grand Rapids level covering a vast area west of The Pas Moraine at about 8.7 $\mathrm{ka} \mathrm{BP}$, and showed an active ice frontal position $150 \mathrm{~km}$ up-ice from Sipiwesk Moraine. The Grand Rapids level configuration presented in Figure 3.7d shows that Lake Agassiz did not include the Cedar Lake area during this phase, since this lake stood at $830^{\prime}$ (253.0 $\mathrm{m}$ ) before recent flooding, which is above the proposed level of $243 \mathrm{~m}$ at isobase 7 . However, a protoCedar Lake having a more restricted area probably existed at that time, with a possible northern outlet into Lake Agassiz. Thorleifson (1996) roughly draws a more restricted lake basin east of The Pas Moraine at approximately $8.0 \mathrm{ka} \mathrm{BP}$ but shows an ice marginal position at the Sipiwesk Moraine for the Grand Rapids/Drunken Point level. As discussed above, 
based on the configuration of the lake during previous levels and the extent of the thick glaciolacustrine belt, it appears that the ice margin was likely up-ice from the Sipiwesk Moraine during the Grand Rapids/Drunken Point levels at circa 8.1/8.0 ka BP.

The high gradients measured on the Ponton strandlines suggest that Lake Agassiz may have continued to discharge through Lake Superior outlets during the Ponton level, at about 7.9 ka BP. (Fig. 3.9), unlike what Thorleifson (1996) recently suggested. If depth at the Nagagami outlet was inadequate to convey the discharge, however, there may have been a two-outlet configuration. The ice margin lay across northeastern Manitoba and northern Ontario, still blocking the drainage to Hudson Bay, and perhaps stood at the Northern Indian, Limestone and Sachigo moraines in northern Manitoba (Klassen, 1983). When Lake Agassiz became confluent with the late Kinojévis level of Lake Ojibway and drained to the Ottawa River (Teller and Thorleifson, 1983; Lewis and Anderson, 1989), it had probably fallen below the Ponton level, perhaps to the Setting level described here. Therefore, the beginning of drainage to Lake Ojibway, when the lake drainage ceased to discharge into Lake Superior through the eastern outlets, would have started after $7.9 \mathrm{ka} \mathrm{BP}$, about 600 years later than originally proposed by Teller and Thorleifson (1983), but closer to the approximate age of 8.0 ka suggested by Thorleifson (1996).

\subsubsection{History of shoreline deformation}

Present day gradients of pro-glacial lake strandlines provide a record of the differential vertical movements that have occurred since the shoreline was formed (Walcott, 
1972). Strandline gradients decrease exponentially with diminishing age in formally glaciated areas (e.g., Andrews and Dugdale, 1970; Mörner, 1980), reflecting the decreasing rate of glacio-isostatic rebound in the time period since ice retreat (Peltier, 1994). Decreasing gradients on Lake Agassiz strandlines have been observed in the Flin Flon region from the older to the younger levels, from about $0.34 \mathrm{~m} \mathrm{~km}^{-1}$ to $0.22 \mathrm{~m} \mathrm{~km}^{-1}$ between isobases 7 and 8 (Table 3.2). These gradients compare with isostatic tilts obtained from other Lake Agassiz paleo-shorelines and from raised shorelines surrounding major lakes in Manitoba (Fig. 3.10), which showed a good agreement with an exponential glacio-isostatic model (Lewis and Todd, 1996; Tackman et al., 1998). However, the tilting of the Ponton and Setting levels documented in this paper refutes the idea of little or no-tilting during the Holocene suggested by earlier workers. In contrast, it strongly supports the configuration of a dry region in the South Basin of Lake Winnipeg at circa 8.0 ka first suggested by Ringrose (1975), depicted by Teller (1985), and well documented by the recent Lake Winnipeg Project Team (Todd et al., 1998).

Shoreline gradients in the Flin Flon region have also shown that the water planes have been regionally up-tilted to the northeast and deformed into shallow curves with the amount of deformation decreasing away from the ice front. Because of differential rates of uplift between the northeast and the southwest extremity of the study area, the gradients of the shorelines for each level are almost as much as two times higher near Setting Lake than $200 \mathrm{~km}$ further south near Grand Rapids. The northeastward direction of maximum tilt reflects the pattern of deformation centred in areas of maximum ice thickness during the last 
Table 3.2 Summary of strandline gradients.

\begin{tabular}{lcccc} 
& \multicolumn{2}{c}{ Average gradients $(\mathrm{cm} / \mathrm{km})$} & Total uplift $(\mathrm{m})$ & $\begin{array}{c}\text { Approximate } \\
\text { Level }\end{array}$ \\
\cline { 2 - 3 } & isobases $7-8$ & isobases 8-9 & isobases $7-9$ & age $\left({ }^{14} \mathrm{C}\right.$ ka BP$)$ \\
\hline Ponton & $0.24^{\mathrm{a}}$ & 0.29 & $47^{\circ}$ & 7.9 \\
Drunken Point & 0.23 & 0.31 & 53 & 8.0 \\
Grand Rapids & 0.24 & - & 52 & 8.1 \\
Gimli & 0.25 & - & 57 & 8.2 \\
The Pas & 0.33 & - & 70 & 8.2 \\
Stonewall & 0.34 & - & 70 & 8.3 \\
\hline
\end{tabular}

a Isobases 7.25 to 8 . Average gradient is approximately $0.22 \mathrm{~m} / \mathrm{km}$.

b Isobases 7.25 to 9 . 


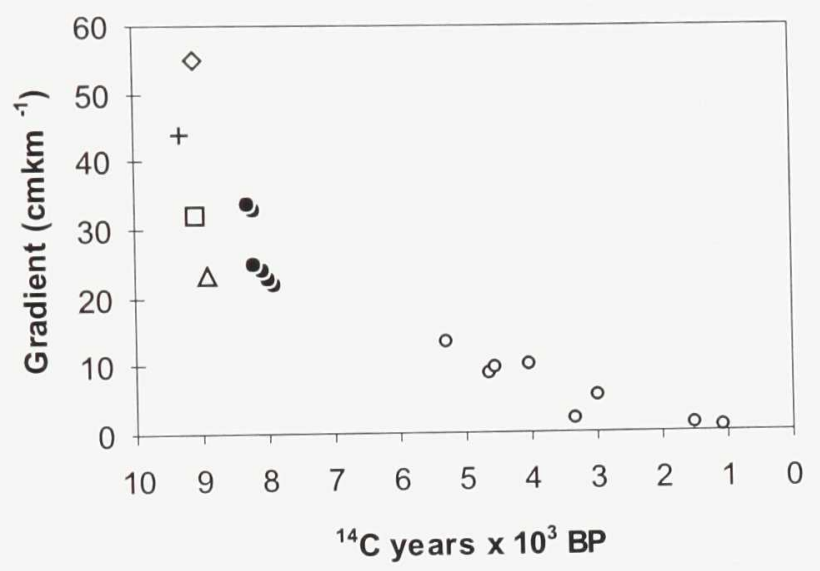

Figure 3.10 Lake strandline gradients as a function of age in central Manitoba, using Teller and Thorleifson (1983) isobases. Shoreline gradients measured in this study are plotted as filled circles, using the age presented in Table 3.2 for each level (isobases 7 to 8 ). The slopes and ages for the Campbell shorelines are from Thorleifson (1996) between isobases 5-6 (open square) and 7-8 (open diamond), and from Rayburn (1997) between isobases 5 to 7 (cross). The gradient of the Burnside shoreline was given by Tackman (1997) between isobases 4.5 and 5.75 (open triangle). Gradients and ages given by Tackman (1997) and Nielsen et al. (1987) on raised shorelines around modern lakes in south-central Manitoba (open circles) are also shown. 
glacial maximum (LGM). Existing models on Laurentide Ice Sheet topography during the LGM have shown conflicting results, mainly thicker ice over Hudson Bay (CLIMAP, 1981) that is spatially coincident with the Hudson Bay Free-air gravity pattern (Goodacre et al., 1987), or a multi-dome configuration supported by geological data, with ice centers all around Hudson Bay (Shilts, 1980; Dyke and Prest, 1987a; Peltier, 1994; Clark et al., 1996). Nevertheless, the northeast upward tilting of the once-leveled paleo-shorelines indicates that glacial rebound has been generally greater to the northeast, in agreement with models of past and present vertical surface motions.

When converting the probable radiocarbon age of the shorelines to calendar years (Lowell and Teller, 1994), about 700 years (400 ${ }^{14} \mathrm{C}$ years) of uplift probably separates the Stonewall level from the Ponton level. Although the exact amount of total uplift for a continental interior region cannot be determined directly from shoreline elevations, the total relative uplift between two isobases can be determined (Table 3.2). The average change in uplift rates between isobases 7 and 9 therefore reaches as much as $75 \mathrm{~cm}$ century ${ }^{-1}$ or $3.8 \mathrm{~mm}$ $100 \mathrm{~km}^{-1}$ year $^{-1}$ for the Stonewall level since the formation of the shoreline, using the calendar age of $9.3 \mathrm{ka} \mathrm{BP}$ for a $8.3 \mathrm{ka}{ }^{14} \mathrm{C} \mathrm{BP}$. Present-day vertical movement rates are up to $10 \mathrm{~mm}$ year ${ }^{-1}$ in Hudson Bay and tilting reaches up to $1-2 \mathrm{~mm} 100 \mathrm{~km}^{-1} \mathrm{year}^{-1}$ in central and eastern Canada (James and Lambert, 1993).

\subsection{Summary}

The succession of near-parallel strandlines recently mapped in the Flin Flon region 
records a series of six levels of Lake Agassiz: the Stonewall, The Pas, Gimli, Grand Rapids, Drunken Point and Ponton, which formed between approximately $8.3 \mathrm{ka}$ and $7.9 \mathrm{ka}{ }^{14} \mathrm{C} \mathrm{BP}$. Elevation measurements of newly-recognized strandlines and correlation with existing shoreline data indicate that the present-day gradient of the shorelines increases to the northeast, and that the corresponding paleo-water planes have been tilted and deformed during the Holocene. Gradients decrease from the highest to the lowest level, from about $0.34 \mathrm{~m} \mathrm{~km}^{-1}$ to $0.22 \mathrm{~m} \mathrm{~km}^{-1}$ between isobases 7 and 8 of the Teller and Thorleifson (1983) system. These gradients are in agreement with the exponential glacial rebound model suggesting that they represent a fair approximation of regional differential isostatic uplift rates related to the relief of the Laurentide Ice Sheet load. The amount of tilt is almost twice as high near Setting Lake than in the Grand Rapids area, consistent with models of thicker ice to the northeast. The tilting of the Ponton level, and the existence of a tilted paleo-water plane that possibly formed about $15 \mathrm{~m}$ below the Ponton shoreline, here named the Setting level, refutes the idea of no-tilting in the Holocene in central Manitoba and Saskatchewan.

Because Lake Agassiz was impounded in front of the retreating ice margin, water levels were mainly controlled by the position of the outlets relative to the ice front. Climate and drainage rearrangements also influenced lake levels, but these are considered minor in an overflowing pro-glacial lake compared to ice margin and outlet positions. Differential uplift of outlets was a major factor farther south (Thorleifson, 1996), but was probably less significant in the study area because of its relative position along the isobases of the corresponding outlets. The position of the shorelines and their degree of isostatic uplift can 
further constrain the relative chronology of deglaciation. The Stonewall, The Pas and Gimli shorelines formed as Lake Agassiz discharged to the Atlantic Ocean through the eastern outlets near Lake Nipigon, while the ice margin was positioned up-ice from Hargrave Moraine, possibly at Sipiwesk Moraine during the Stonewall level. During the Grand Rapids, Drunken Point and Ponton levels, Lake Agassiz was perhaps diverted to outlets directly entering Lake Superior, and the ice margin lay across northeastern Manitoba and northern Ontario, still blocking the drainage to Hudson Bay. After it had drained completely from the Flin Flon region, Lake Agassiz possibly overflowed directly into Lake Ojibway, after $7.9{ }^{14} \mathrm{C}$ BP. The regional post-glacial uplift history of the Flin Flon region has implications for ice sheet modeling, understanding of the Earth structure, and climate change. 


\section{CHAPTER IV: IMPACT OF A BASE METAL SMELTER ON THE GEOCHEMISTRY OF SOILS}

(a paper published in Canadian Journal of Earth Sciences, by I. McMartin, P.J. Henderson and E. Nielsen; 1999, Vol. 36, p. 141-160)

\subsection{Introduction}

Heavy metal contamination of soils near metal smelters is well known (Davies, 1983; Ripley et al., 1996). In the vicinity of smelters, emitted metal concentrations decrease with distance from the source of emissions, and with depth through the soil profile. The surface metal enrichment is attributed to atmospheric fallout of smelter-derived particulate emissions (Dumontet et al., 1992; Freedman and Hutchinson, 1980). Problems occur in evaluating natural versus anthropogenic metal loading in soils contaminated by smelter fallout, where natural accumulation processes and background variations are poorly known (Laville-Timsit and Lecompte, 1992; Reimann et al., 1998). In unpolluted soils, naturally occurring metals such as $\mathrm{Pb}$ and $\mathrm{Hg}$ are concentrated in humus due to long-term upward translocation by plant roots and accumulation through plant litter decay (Stevenson, 1994). Once in the surface organic layer, these metals tend to be retained by humic substances and other mineral colloids. Hence, assessment of the anthropogenic heavy metal content in contaminated soils is difficult, but essential for modelling metal deposition in soils around smelters (Godin et al., 1985; Niskavaara et al., 1996). In this paper, the regional dispersal patterns of As and five heavy metals $(\mathrm{Cd}, \mathrm{Cu}, \mathrm{Hg}, \mathrm{Pb}, \mathrm{Zn})$ emitted from the base metal smelter at Flin Flon will be examined in surface soils and at depth, using an extensive and comprehensive regional 
geochemical database for humus and underlying till. The objective is to estimate the relative proportion and extent of anthropogenic contamination in the surface terrestrial environment.

Previous studies in the Flin Flon area have shown that smelter metals concentrations decrease away from the smelter in surface mineral and organic soils (Hogan and Wotton, 1984; Pip, 1991; Zoltai, 1988). However, in these studies, conclusions were based on data collected at a limited number of sampling sites, which were located predominantly downwind of the smelter stack. The data presented in this paper result from a geochemical mapping project conducted in the Flin Flon region, central Manitoba and Saskatchewan, by the Geological Survey of Canada and Manitoba Energy and Mines (Henderson, 1995a; McMartin et al., 1996). Humus and till samples were collected at more than 1600 sites, within a $200 \mathrm{~km}$ radius of the stack. At six of these sites, soil profiles were sampled in detail to assess the extent of sub-surface contamination as a function of distance from the smelter. In addition, humus profile and forest litter samples were collected at selected sites to evaluate the distribution of heavy metals on the forest floor and the relative significance of the regional humus database.

\subsection{Study area}

\subsubsection{Location}

Flin Flon is the site of a base metal mining and smelting complex owned and operated by Hudson Bay Mining and Smelting Company Limited (H.B.M. \& S.). The city is located in west central Manitoba on the border with Saskatchewan $\left(55^{\circ} \mathrm{N}, 102^{\circ} \mathrm{W}\right)$, in an 
otherwise remote boreal forest environment approximately $650 \mathrm{~km} \mathrm{NNW}$ of Winnipeg. The study area straddles the Paleozoic/Precambrian Shield boundary and covers approximately $36,000 \mathrm{~km}^{2}\left(99^{\circ} \mathrm{W}\right.$ to $103^{\circ} \mathrm{W}$ longitude; $54^{\circ} \mathrm{N}$ to $55^{\circ} 15^{\prime}$ latitude) (Fig. 4.1).

\subsubsection{Regional geology}

Bedrock lithologies within the Precambrian Shield have been grouped into two major lithotectonic domains (Fig. 4.2): the Flin Flon Belt and the Kisseynew Domain (Lucas et al., 1999). The Flin Flon Belt comprises metamorphosed volcanic and sedimentary rocks and associated intrusives. These rocks are structurally overlain by metamorphosed turbidites of the Kisseynew Domain. Fifteen kilometres south of Flin Flon, the Precambrian Shield is unconformably overlain by flat-lying unmetamorphosed Paleozoic dolostones, covering the entire southern half of the study area (Fig. 4.2). Numerous base and precious metal occurrences have been reported in the area, particularly in the Flin Flon Belt (Lucas et al., 1999). In the Flin Flon and Snow Lake areas, producing and past-producing mines have been developed in large $\mathrm{Zn}$ and $\mathrm{Cu}$ ore bodies $( \pm \mathrm{Au}, \mathrm{Cd}, \mathrm{Pb}, \mathrm{Ag})$, classified as volcanogenic massive sulphide (VMS) deposits associated with felsic volcanic rocks, and in minor deposits of porphyry-style $\mathrm{Cu}(\mathrm{Mo}-\mathrm{Au})$ mineralization.

The Flin Flon region lies in an area influenced by ice flowing in two directions during the last glaciation (Dyke and Prest, 1987a). On the Shield and west of The Pas Moraine, the predominant direction of ice flow indicators is south-southwest (Fig. 4.1), indicating glaciation from a Keewatin dispersal centre (McMartin et al., 1996). Tills deposited by 


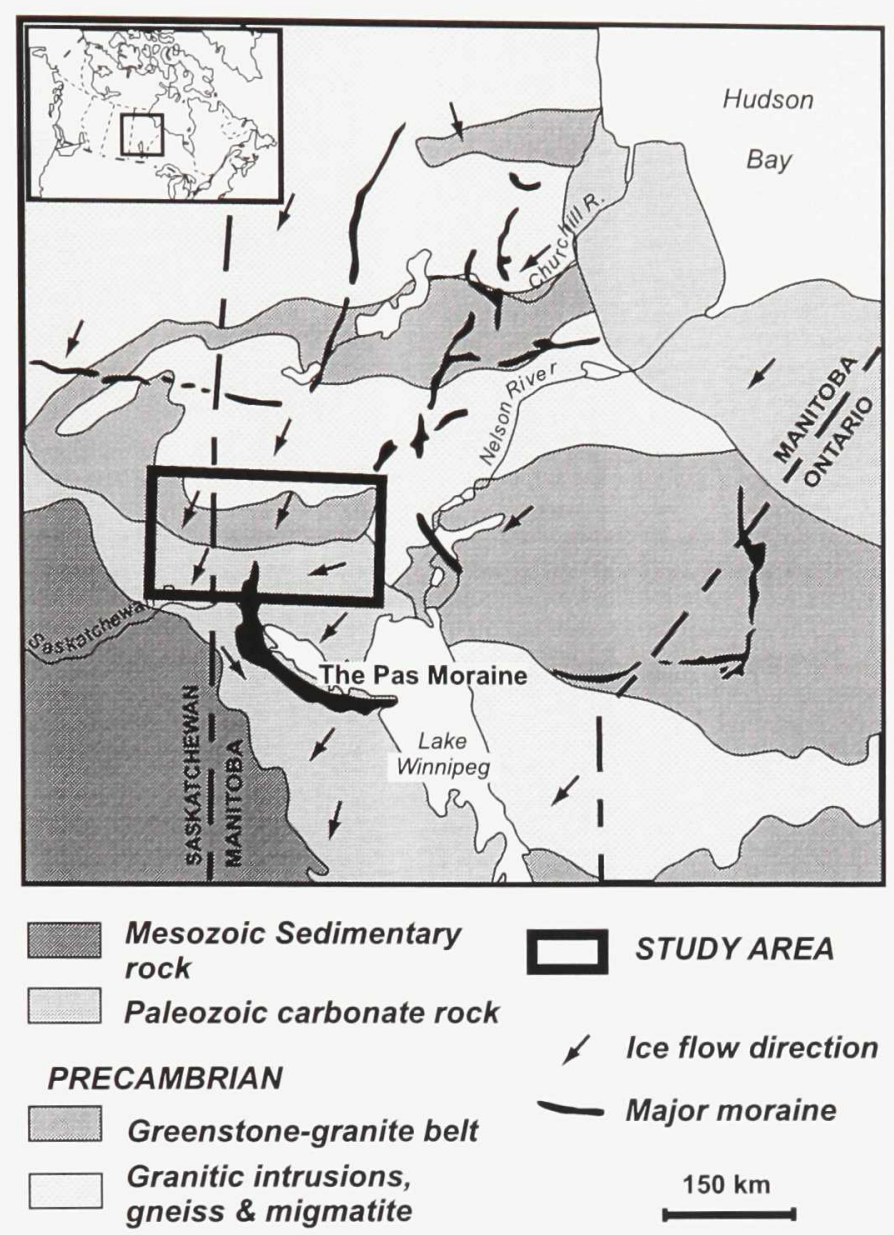

Figure 4.1 Location map of study area showing bedrock domains, major glacial landforms, and generalized ice flow directions. 

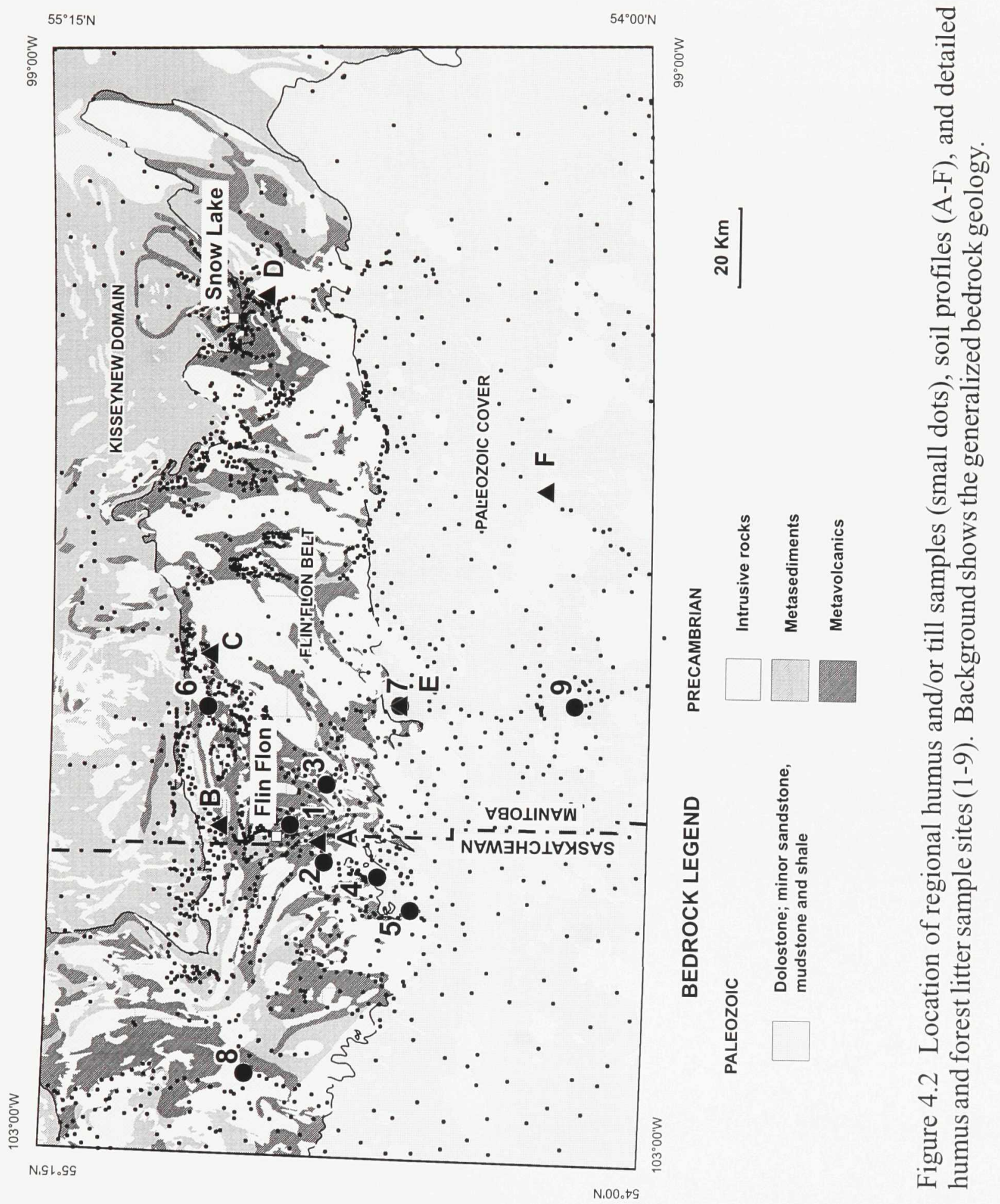
Keewatin ice generally reflect local bedrock composition: those underlain by Shield lithologies are sandy, non-calcareous and naturally enriched in heavy metals, whereas tills overlying carbonate rocks are moderately calcareous, sandy silty and generally depleted in metals. East of The Pas Moraine, predominant ice flow indicators have a west-southwest orientation (Fig. 4.1), indicating ice flow from a Labrador Sector dispersal centre (McMartin et al., 1996). Tills deposited by Labradorean ice have both a local and a recognizable distal component. Following ice retreat, the study area was inundated by glacial Lake Agassiz, and a discontinuous veneer of glaciolacustrine sediments is found throughout the area.

\subsubsection{Climate}

The climate is continental, characterized by cold winters (January mean temperature: $-21.1^{\circ} \mathrm{C}$ ), and relatively warm summers (July mean temp.: $18.3^{\circ} \mathrm{C}$ ) (Environment Canada, 1993). Total average precipitation is $477.9 \mathrm{~mm}$ per annum, with $342.6 \mathrm{~mm}$ falling as rain and $137.2 \mathrm{~cm}$ falling as snow (1927-1990). Wind directions and velocities are fairly well distributed, but predominate to the southeast and southwest, with strong components to the northwest, the north and the south (Fig. 4.3).

\subsection{Sources and nature of emissions}

Atmospheric emissions related to the Flin Flon smelter complex consist of gases and particulates escaping from the central chimney and from other smelter process units, as well as wind-blown dusts derived from dried tailings, exposed ore residue dumps, and ore and concentrate carriers during transportation (Franzin, 1984). The region is also influenced by 


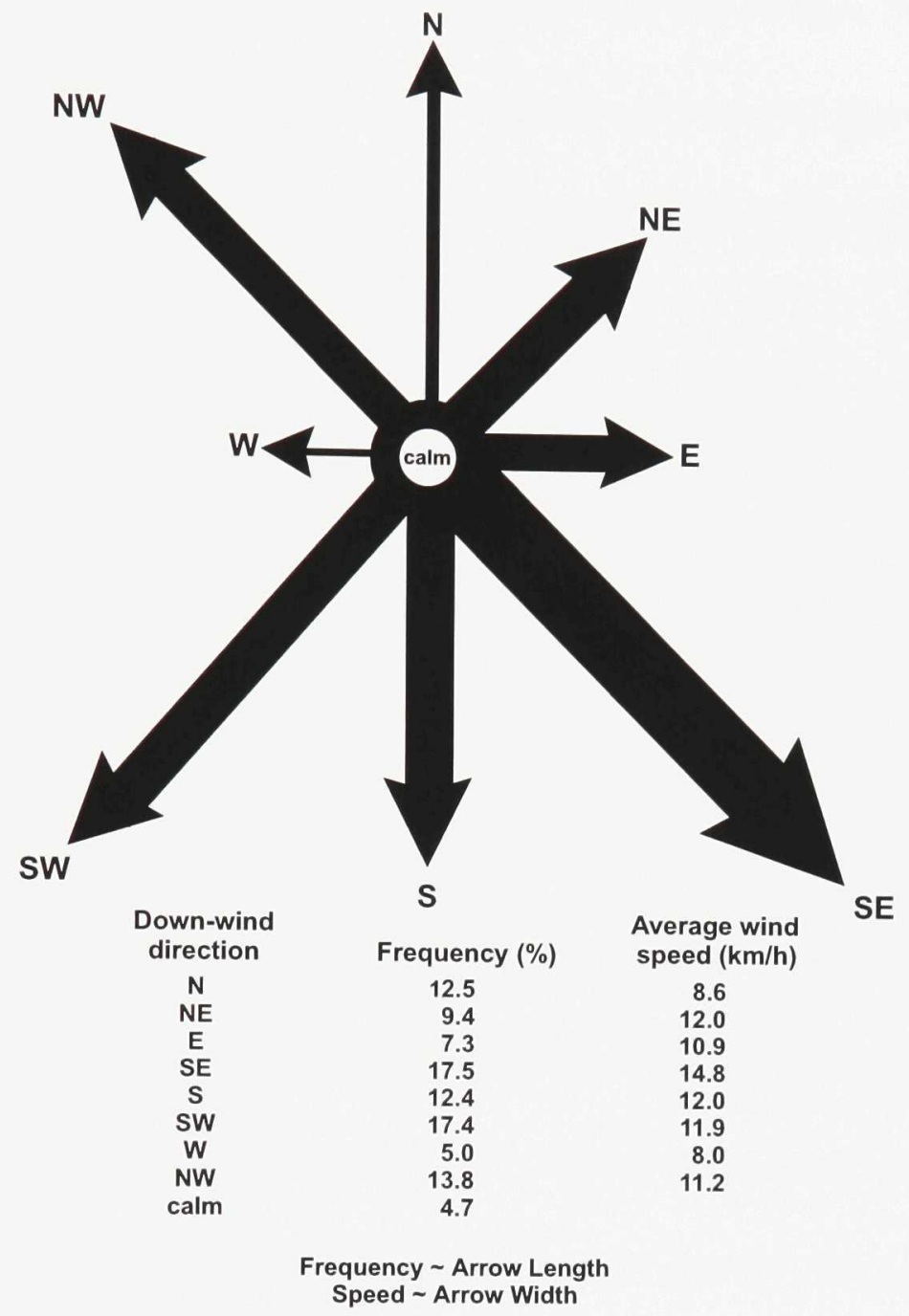

Figure 4.3 Wind rose data for the Flin Flon region. Frequency represents the percentage of time a direction was downwind of the smelter (1927-1990, Environment Canada, 1993). 
natural sources of metal-bearing aerosols, including wind-blown soil and sediment, forest fire debris, and biogenic particulates. Discussion in this section is limited to atmospheric particulates emitted from the main stack, which account for approximately $93 \%$ of total emissions of particulate material from the smelter complex (Franzin, 1984).

The Flin Flon mine and smelter complex produces, on site, $\mathrm{Zn}, \mathrm{Cu}$, and $\mathrm{Cd}$ metals, in addition to $\mathrm{Pb}$ concentrates and $\mathrm{Au}, \mathrm{Ag}$, Se, and Te by-products, recovered and refined offsite (Franzin et al., 1979). The complex has been in operation since 1930, processing sulphide ores from local mines. Prior to 1974, particulate emissions released from low (30 m) smelter stacks have been estimated at 7,150 t/year (Table 4.1). In 1974, the lower stacks were replaced by a higher stack ( $251 \mathrm{~m})$, and a decrease in emissions to $6,834 \mathrm{t} / \mathrm{year}$ resulted (Table 4.1). In 1995, new technology in the smelter process further reduced particulate emissions by almost $90 \%$ to about 632 t/year. Today, most stack dusts ( $90 \%)$ escape from the smelter baghouse (Salomon de Frieberg, 1993), but historically, the emissions were derived equally from the $\mathrm{Zn}$ precipitator (48\%) and the smelter baghouse (48\%) (R. Tardiff, HBMS, pers. comm., 1996).

The composition of the emissions has varied, depending on the ore composition, and the major improvements in processing, recovering and smelting that have occurred over the years to comply with environmental standards. Historically, the emissions were dominated by $\mathrm{Zn}, \mathrm{Fe}$ and $\mathrm{Pb}$, with lesser quantities of $\mathrm{As}, \mathrm{Cu}, \mathrm{Cd}$, and $\mathrm{Hg}$, and trace amounts of $\mathrm{Ag}, \mathrm{Al}$, $\mathrm{Mg}, \mathrm{Mn}, \mathrm{Se}, \mathrm{Sb}, \mathrm{Ni}, \mathrm{Cr}$ and $\mathrm{Co}$. Estimated values of historical emissions of $\mathrm{Zn}, \mathrm{Pb}, \mathrm{Cu}, \mathrm{As}$, 
Table 4.1 Historical emissions for the Flin Flon smelter (J. Nilsen, HBMS, pers. communication, 1996).

\begin{tabular}{ccccc} 
& $1931-1974^{a}$ & $1975-1995^{b}$ & Total $(1931-1995)$ & $\%$ of total emissions \\
\hline Total dust loss ( $\mathrm{t}$ ) & 314,579 & 143,520 & 458,099 & 100.00 \\
Average dust loss (t/year) & 7,150 & 6,834 & 7,048 & - \\
& & & & \\
Element losses (t) & & & & 28.54 \\
$\mathrm{Zn}$ & 88,505 & 42,229 & 130,734 & 5.08 \\
$\mathrm{~Pb}$ & 15,826 & 7,431 & 23,257 & 1.58 \\
$\mathrm{Cu}$ & 4,827 & 2,409 & 7,236 & 0.89 \\
$\mathrm{As}$ & 2,783 & 1,284 & 4,067 & 0.49 \\
$\mathrm{Cd}$ & 1,009 & 1,248 & 2,257 & 0.13 \\
$\mathrm{Hg}$ & 398 & 185 & 583 & 36.71 \\
\hline Total (6 elements) & 113,348 & 54,786 & 168,134 &
\end{tabular}

${ }^{a}$ Estimated

${ }^{b}$ Based on actual field measurements 
$\mathrm{Cd}$, and $\mathrm{Hg}$ are compiled in Table 4.1. Few data are available on the actual mineral composition of the escaping dusts. Analyses of archived dusts collected in the smelter baghouse and in the $\mathrm{Cu}$ and $\mathrm{Zn}$ precipitators indicate that retained particles are concentrated in the fine to medium silt size range $(2-31 \mu \mathrm{m})$. The dust varies in composition depending on the source, but consists predominantly of angular and spherical particles of $\mathrm{Cu}, \mathrm{Zn}, \mathrm{Fe}$ sulphates and, to a lesser extent, oxides and sulphides commonly containing traces of $\mathrm{Pb}, \mathrm{As}$ and/or Cd. Particles emitted from the stack, however, have passed through the precipitators and baghouse and consequently may vary slightly in composition and size.

\subsection{Previous work}

Dispersal patterns of heavy metals in the surface environment near Flin Flon have been studied mostly in precipitation (Franzin et al., 1979; Phillips et al., 1986; Shewchuk, 1985), lake water (Van Loon and Beamish, 1977), and lake sediments (Harrison and Klaverkamp, 1990). These authors established that $\mathrm{Zn}, \mathrm{Cu}, \mathrm{Cd}, \mathrm{As}, \mathrm{Pb}$ and $\mathrm{Hg}$ deposition decrease with distance from the smelter and showed that metal dispersal patterns varied with the element and prevailing wind directions.

In a study of forest soils near Flin Flon, Hogan and Wotton (1984) found that levels of $\mathrm{Zn}, \mathrm{Cu}$ and $\mathrm{Pb}$ close to the source were elevated and declined rapidly in a south-southeast direction, at sites up to 35 to $40 \mathrm{~km}$ from the smelter stack. By studying 16 till profiles (Ah, Ae, B and C horizons) located less than $17 \mathrm{~km}$ from the smelter, Samson (1986) observed decreasing smelter element concentrations with depth through the soil profile. In a study of 
86 peatlands within a $250 \mathrm{~km}$ radius from Flin Flon, Zoltai (1988) found that $\mathrm{Zn}, \mathrm{Pb}, \mathrm{Cu}$, and As concentrations were high in surface peat up to $110 \mathrm{~km}$ from the source and decreased exponentially away from the stack. Pip (1991) examined metal concentrations in soils and garden produce at 12 locations in the vicinity of the Flin Flon smelter $(<13 \mathrm{~km})$, and found that $\mathrm{Cd}, \mathrm{Cu}$ and $\mathrm{Pb}$ concentrations decreased significantly with increasing distance from the smelter. The maximum radius of metal deposition calculated or estimated from studies in soils and other material around Flin Flon is given in Table 4.2.

In the Snow Lake area, detailed multi-media and regional scale till and humus sampling programs were designed to evaluate the geochemical response of soils to massive sulphide deposits (VMS) and associated alteration zones (Kaszycki et al., 1996; Kaszycki and Hall, 1996). Smelter contamination was not recognized in this area, although at two sites from the regional study, local airborne contamination related to mine dusts from tailings and open pit mining operations was postulated in humus.

Based on results from the regional geochemical survey around Flin Flon (Henderson, 1995a; McMartin et al., 1996), detailed analysis of selected humus and till samples collected along two transects extending away from the smelter was undertaken to assess the physical and chemical characteristics of heavy metals derived from the smelter contamination (Henderson and McMartin, 1995; Henderson et al., 1998). These results complement the data presented in this paper and will be discussed further when assessing the distribution of trace elements on the forest floor and the differences in the patterns of surface contamination 
Table 4.2 Calculated or estimated maximum radius of smelter element deposition (km) around Flin Flon from previous work.

\begin{tabular}{cccccccc}
$\mathrm{Zn}$ & $\mathrm{Pb}$ & $\mathrm{Cu}$ & $\mathrm{As}$ & $\mathrm{Cd}$ & $\mathrm{Hg}$ & Source & Material \\
\hline \multicolumn{6}{l}{ Elements in precipitation and lake } \\
$\begin{array}{cccccccc}264 & 87 & 60 & 68 & 284 & - & \text { Franzin et al. (1979) } & \text { rain and snow } \\
>100 & >100 & - & >100 & - & - & \text { Shewchuk (1985) } & \text { snowpack } \\
>38 & >38 & >38 & - & >38 & - & \text { Phillips et al. (1986) } & \text { snowpack } \\
>70 & - & >70 & - & - & - & \text { Van Loon and Beamish (1977) } & \text { lake water } \\
68 & - & 68 & - & 68 & >84 & \text { Harrison and Klaverkamp (1990) } & \text { lake sediment }\end{array}$
\end{tabular}

\section{Elements in soils}

\begin{tabular}{cccccccc}
38 & $35-40$ & $35-40$ & - & - & - & Hogan and Wotton (1984) & forest litter \\
$>17$ & $>17$ & $>17$ & $>17$ & $>17$ & - & Samson (1986) & till \\
77 & 65 & 110 & 110 & - & - & Zoltai (1988) & peat \\
- & $>13$ & $>13$ & - & $>13$ & - & Pip (1991) & garden soils \\
\hline
\end{tabular}


among the smelter-related elements.

\subsection{Methods}

\subsubsection{Sampling procedures}

Humus and till were systematically sampled in the Flin Flon region at an average spacing of $4 \mathrm{~km}$ (McMartin et al., 1996). A total of 1817 till samples were collected (Fig. 4.2). At each site, a 3-kg till sample was collected in the upper $\mathrm{C}$ horizon of soils. In addition, six excavated exposures in till were sampled in detail, at 10 to $50 \mathrm{~cm}$ intervals (Fig. 4.2). Regionally, 1639 humus samples (50-100 g) were collected directly over or in an area immediately adjacent to a till sample (Fig. 4.2). The dark, well decomposed organic part of the uppermost forest soil horizon was sampled $(\mathrm{H})$. At nine sites selected from the regional survey, humus profiles were sampled in detail (Fig. 4.2). The homogenized humus layer (total humus accumulation), the top (surface) and bottom half (sub-surface) of the humus profile and the overlying forest litter were collected separately in plastic boxes and stainless steel short cores of known volumes. These sites were selected based on distance from the smelter, accessibility and available mineralogical and chemical partitioning data.

\subsubsection{Analytical procedures}

Humus samples were air-dried and sieved to $<0.425 \mathrm{~mm}$. Till samples were air-dried and sieved to $<0.063 \mathrm{~mm}$ fraction; the clay-size fraction $(<0.002 \mathrm{~mm})$ was separated by centrifugation and decantation (Lindsay and Shilts, 1995). Geochemical analyses for a number of major and trace elements (Ag, Al, As, Ba, Bi, Ca, Cd, Co, Cr, Cu, Fe, Hg, K, La, 
$\mathrm{Mg}, \mathrm{Mn}, \mathrm{Mo}, \mathrm{Na}, \mathrm{Ni}, \mathrm{P}, \mathrm{Pb}, \mathrm{Sb}, \mathrm{Sc}, \mathrm{Sr}, \mathrm{Ti}, \mathrm{V}$, and Zn) were conducted on the humus fraction $(<0.425 \mathrm{~mm})$ and the clay-size fraction of till using ICP-AES (inductively coupled plasma atomic emission spectrometry) after a hot acid leach in aqua regia solution. Mercury was determined using cold-vapour atomic absorption spectrometry (CV-AAS) following aqua regia digestion. Analysis of duplicate samples and laboratory standards was used to monitor analytical accuracy and precision (Henderson, 1995a; McMartin et al., 1996). The silt plus clay $(<0.063 \mathrm{~mm})$ fraction of till samples was analysed for total carbonate content using atomic absorption spectrometry (AAS), following digestion in $\mathrm{HCl}$ solution (Ross, 1986). In addition, a subset of till samples was analysed geochemically for trace elements using the $<0.063 \mathrm{~mm}$ fraction (Henderson, 1995a).

For the detailed sampling program, humus samples were air dried and weighed, for bulk density and moisture content determination. The samples were sieved to $<0.425 \mathrm{~mm}$, and the dry weight of the 2 fractions was determined $(<0.425$ and $>0.425 \mathrm{~mm})$. All size fractions of humus (bulk, $<0.425 \mathrm{~mm},>0.425 \mathrm{~mm}$ ) and forest litter samples (pulverized) were analysed geochemically using the techniques described above for regional humus samples. Total organic content was determined by loss-on-ignition after heating a small proportion to approximately $500^{\circ} \mathrm{C}$ for one hour (Sheldrick, 1984).

\subsection{Results}

4.6.1 Regional distribution of heavy metals in humus

Regional geochemical data and proportional dot maps showing distributions of 
concentrations of all analysed elements for the $<0.425 \mathrm{~mm}$ fraction of humus collected in the Flin Flon region are reported elsewhere (Henderson, 1995a; McMartin et al., 1996). Geochemical maps indicate that total concentrations of $\mathrm{As}, \mathrm{Cd}, \mathrm{Cu}, \mathrm{Hg}, \mathrm{Pb}$, and $\mathrm{Zn}$ are anomalously high in the vicinity of Flin Flon and decrease in all directions with distance from the smelter, until regional background values are reached. The maps show that concentrations are slightly skewed to the SE, in agreement with the prevailing wind direction for the Flin Flon region (cf. Fig. 4.3). The proportional dot maps of $\mathrm{Cu}, \mathrm{Zn}$ and $\mathrm{As}$ in humus are shown in Fig. 4.4. The log-concentrations of these elements decrease linearly as a function of the log-distance from the main stack, according to an inverse curvilinear relationship of the type $y=a x^{-b}$, where $y$ is the element concentration, $x$ the distance from the stack, and $a$ and $b$ variables of the specific trendlines (Fig. 4.5). A similar relationship between metal concentration and distance from the stack was found by previous authors using precipitation and lake water samples, although the parameters of the equations vary significantly (Franzin et al., 1979; Phillips et al., 1986; Van Loon and Beamish, 1977). For this study, correlation coefficients (R) on the fitted curves are highly significant, varying from 0.66 to 0.88 for the major smelter elements (Fig. 4.5).

Concentrations of trace elements occurring in low quantities or absent from the smelter emissions (e.g., Mn, Se, Ni, Cr, Co, Al) show no significant correlation with distance from the smelter. As an example, the proportional dot map of $\mathrm{Ni}$ in humus is presented in Fig. 4.4b. 

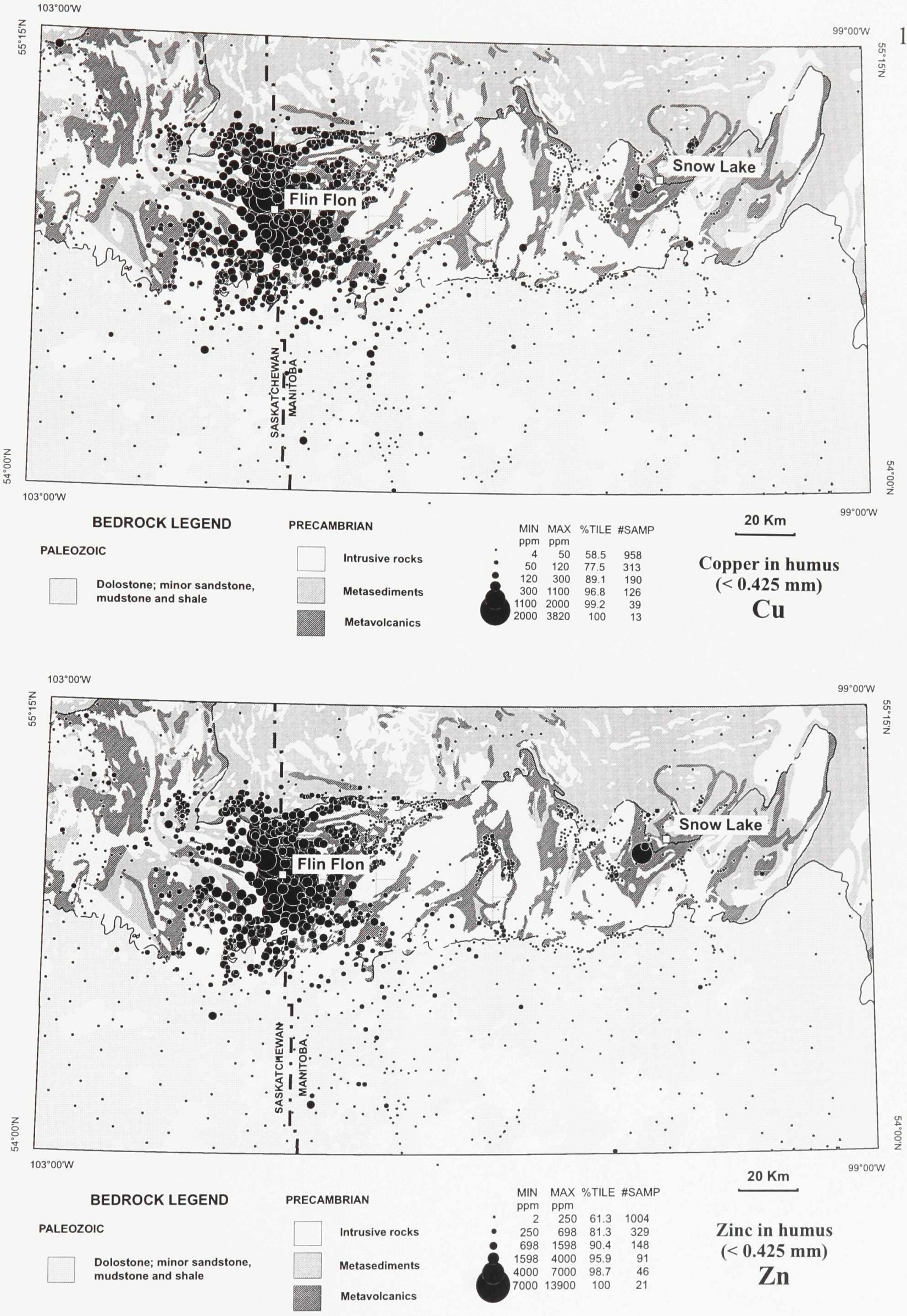

Figure 4.4 Regional distribution of selected elements in the $<0.425 \mathrm{~mm}$ fraction of humus over simplified bedrock map. (a) $\mathrm{Cu}$ and $\mathrm{Zn}$ in humus. 

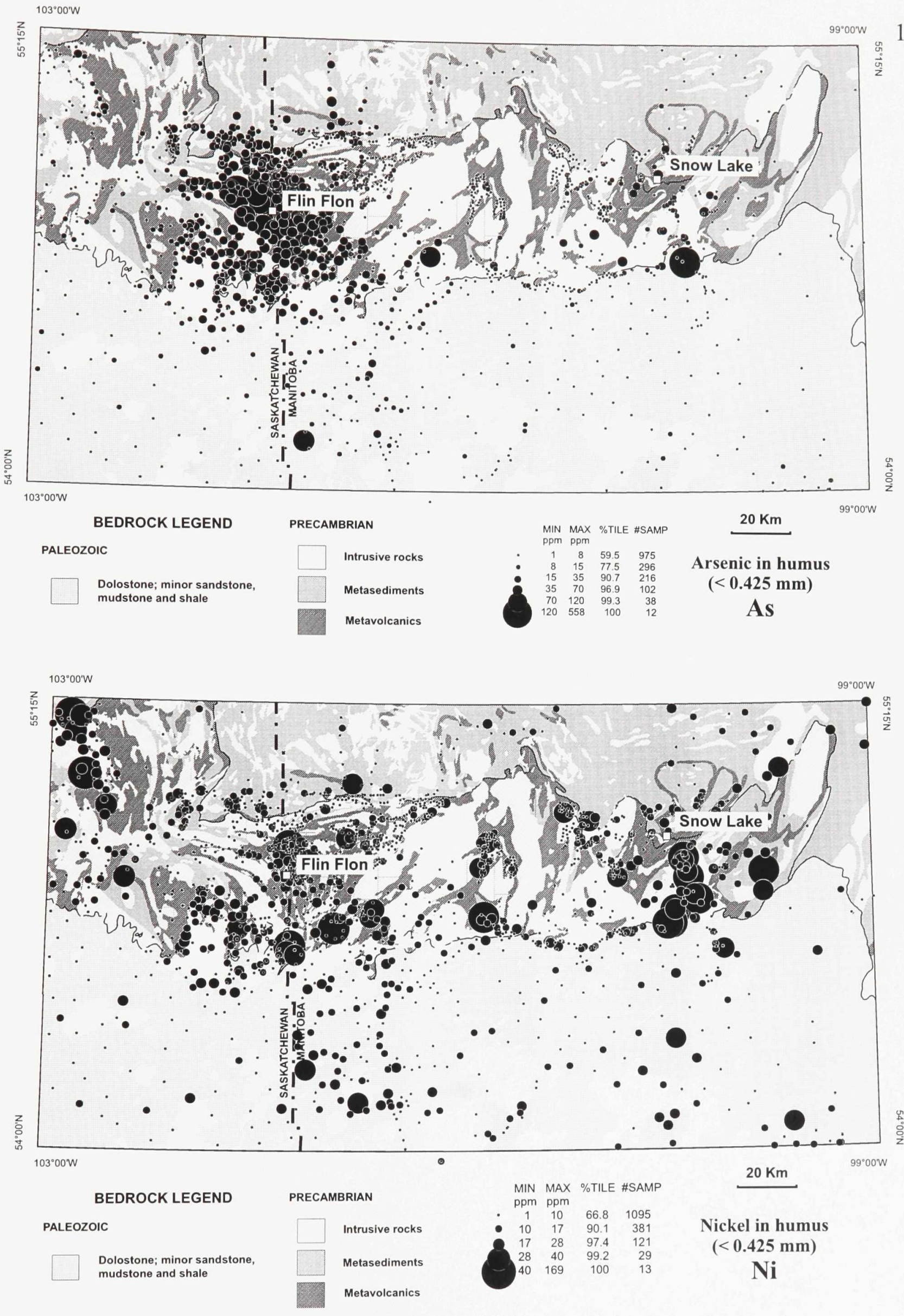

(b) As and Ni in humus. 

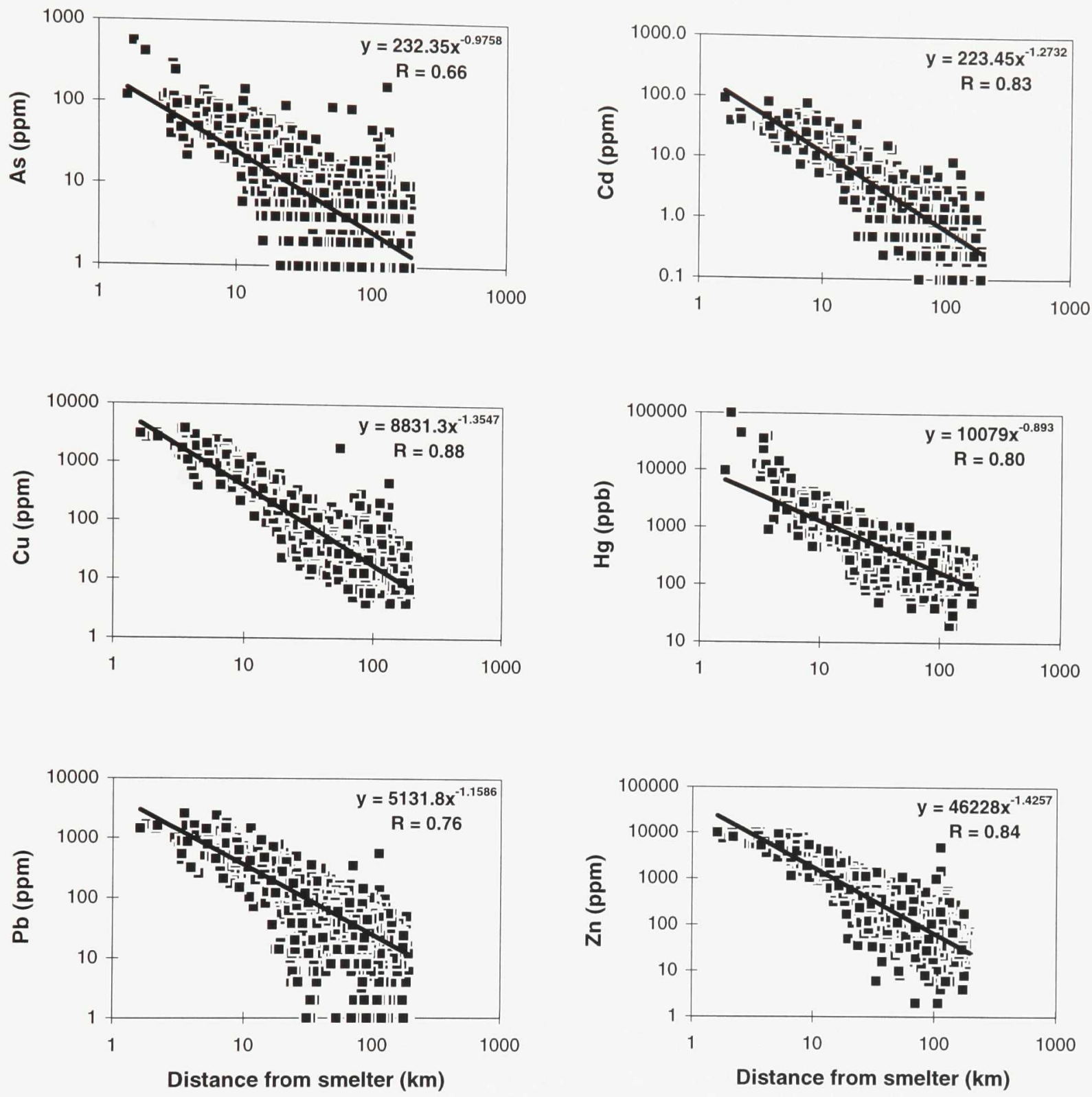

Figure 4.5 Concentrations of major smelter metals in humus as a function of distance from the smelter. Fitted curves of the type $y=a x^{-b}$ and correlation coefficients (R) are shown for each element $(\mathrm{n}=1639)$. 
4.6.1.1 Determination of background levels

The geochemical maps for smelter-related elements in humus show that concentrations are related primarily to distance from the stack at Flin Flon. Estimating the degree of soil contamination resulting from the smelting activity, however, requires an understanding of natural, or "background", concentrations. Levels of metals in uncontaminated soils primarily reflect the nature of the local rock modified to varying degrees by geochemical processes such as leaching or precipitation (Davies, 1983). "Background" concentrations may also include a very small indistinguishable anthropogenic fallout component from long-range atmospheric transport (Ripley et al., 1996).

In this study, median concentrations for each element were determined for samples collected near Snow Lake (Table 4.3), an area where smelter contamination was not recognized in humus samples (Kaszycki et al., 1996). The Snow Lake area is geologically similar to Flin Flon, but removed (>100 km) from the effects of the smelter. Median values were also determined using sample sites located beyond a radius of 0,50 and $75 \mathrm{~km}$ from the smelter (Table 4.3). These calculations indicate that, for the smelter elements, median values decrease significantly between samples collected beyond 0 and $50 \mathrm{~km}$, and vary slightly between samples collected beyond 50,75 and $100 \mathrm{~km}$ from the smelter. A breakdown of samples collected beyond $50 \mathrm{~km}$ from the smelter by the major bedrock units shows that the variation in median values is largely due to the bedrock type (Table 4.4). For example, humus samples have generally higher $\mathrm{Cu}$ and $\mathrm{Zn}$ concentrations at sites collected over volcanic rocks naturally enriched in those metals. Therefore, by eliminating the most highly 
Table 4.3 Median of element concentrations in humus $(<0.425 \mathrm{~mm})$ as a function of distance from the smelter.

$$
\text { All samples Samples }>50 \mathrm{~km}^{a} \quad \text { Samples }>75 \mathrm{~km}^{b} \text { Snow Lake samples }
$$

Element

Smelter elements

$\begin{array}{lcccc}\text { As (ppm) } & 6 & 3 & 3 & 3 \\ \mathrm{Cd}(\mathrm{ppm}) & 1.5 & 1.0 & 0.5 & 0.8 \\ \mathrm{Cu}(\mathrm{ppm}) & 36 & 20 & 17 & 17 \\ \mathrm{Hg}(\mathrm{ppb}) & 300 & 190 & 180 & 176 \\ \mathrm{~Pb}(\mathrm{ppm}) & 56 & 34 & 28 & 33 \\ \mathrm{Zn}(\mathrm{ppm}) & 172 & 84 & 68 & 101\end{array}$

\section{Non-smelterelements}

$\operatorname{Cr}(\mathrm{ppm})$

11

$\mathrm{Ni}(\mathrm{ppm})$

8

11

8

12

11

8

8

\section{Major elements}

\begin{tabular}{lllll}
$\mathrm{Ca}(\%)$ & 0.95 & 1.25 & 1.33 & 1.01 \\
$\mathrm{Fe}(\%)$ & 0.58 & 0.52 & 0.53 & 0.47 \\
$\mathrm{Mg}(\%)$ & 0.22 & 0.31 & 0.38 & 0.35 \\
\hline
\end{tabular}

a Eliminates slightly to extremely contaminated samples (appr. 50\%tile)

$b$ Eliminates very slightly to extremely contaminated samples, and some background samples 
Table 4.4 Median of element concentrations in humus $(<0.425 \mathrm{~mm})$ for samples

$>50 \mathrm{~km}$ from the smelter as a function of underlying bedrock.

\begin{tabular}{|c|c|c|c|c|c|c|c|c|c|}
\hline \multirow[b]{3}{*}{ Element } & \multirow{3}{*}{$\begin{array}{c}\text { All samples } \\
\quad(n=829)\end{array}$} & \multirow{3}{*}{$\begin{array}{c}\text { Samples underlain } \\
\text { by Paleozoic } \\
(n=337)\end{array}$} & \multicolumn{7}{|c|}{ Samples underlain by Precambrian bedrock } \\
\hline & & & \multirow{2}{*}{$\begin{array}{c}\text { Total } \\
(n=492)\end{array}$} & \multicolumn{2}{|c|}{ Volcanics } & \multicolumn{2}{|c|}{ Sediments } & \multicolumn{2}{|c|}{ Intrusive } \\
\hline & & & & Felsic & Mafic & Schists & Gneiss & Felsic & Mafic \\
\hline \multicolumn{10}{|c|}{ Smelter elements } \\
\hline As (ppm) & 3 & 2 & 3 & 3 & 4 & 3 & 3 & 3 & 3 \\
\hline $\mathrm{Cd}(\mathrm{ppm})$ & 1.0 & 0.5 & 1.0 & 1.0 & 1.0 & 0.9 & 1.0 & 0.7 & 0.5 \\
\hline $\mathrm{Cu}(\mathrm{ppm})$ & 20 & 19 & 21 & 17 & 26 & 19 & 20 & 18 & 17 \\
\hline $\mathrm{Hg}(\mathrm{ppb})$ & 190 & 190 & 190 & 223 & 138 & 195 & 238 & 230 & 183 \\
\hline $\mathrm{Pb}(\mathrm{ppm})$ & 34 & 30 & 38 & 40 & 47 & 28 & 30 & 37 & 33 \\
\hline $\mathrm{Zn}(\mathrm{ppm})$ & 84 & 62 & 106 & 143 & 135 & 96 & 82 & 86 & 76 \\
\hline
\end{tabular}

\section{Non-smelter elements}

$\begin{array}{lccccccccc}\mathrm{Cr}(\mathrm{ppm}) & 11 & 13 & 10 & 10 & 10 & 11 & 10 & 9 & 19 \\ \mathrm{Ni}(\mathrm{ppm}) & 8 & 8 & 8 & 7 & 8 & 10 & 9 & 8 & 10\end{array}$

\section{Major elements}

\begin{tabular}{lllllllllll}
$\mathrm{Ca}(\%)$ & 1.25 & 2.00 & 0.90 & 1.39 & 1.06 & 0.76 & 0.73 & 0.65 & 0.91 \\
$\mathrm{Fe}(\%)$ & 0.52 & 0.58 & 0.48 & 0.46 & 0.49 & 0.50 & 0.49 & 0.44 & 0.70 \\
$\mathrm{Mg}(\%)$ & 0.31 & 0.54 & 0.23 & 0.40 & 0.20 & 0.23 & 0.24 & 0.16 & 0.36 \\
\hline
\end{tabular}


contaminated samples ( $<50 \mathrm{~km}$ from smelter), the median value for each element provides a good approximation of regional background concentrations.

\subsubsection{Distances to background}

Based on the regional background levels (Table 4.4, Column 1), the extent of contamination or distance to background was calculated for the major smelter elements, using the regression trendlines presented in Figure 4.5. Results show that distance to regional background varies among elements, averaging $70 \mathrm{~km}$ for $\mathrm{Cd}, 76 \mathrm{~km}$ for $\mathrm{Pb}, 84 \mathrm{~km}$ for $\mathrm{Zn}, 85 \mathrm{~km}$ for $\mathrm{Hg}, 90 \mathrm{~km}$ for $\mathrm{Cu}$, and $104 \mathrm{~km}$ for As. Beyond these distances, element concentrations become inconsistent and can not be related to the point source. These results are similar to those found by Zoltai (1988) from surface peat samples, but differ in order and magnitude to those reported by Franzin et al. (1979) based on the analysis of bulk precipitation samples. These authors estimated a much greater area receiving significant $\mathrm{Zn}$ (264 km) and Cd (284 km) deposition, as opposed to Harrison and Klaverkamp (1990), who used lake sediment analyses to show that $\mathrm{Cu}, \mathrm{Cd}$ and $\mathrm{Zn}$ were not transported further than $68 \mathrm{~km}$ to the northwest. Estimates of distances to background presented here assume a circular distribution pattern for smelter contamination, but as shown in Fig. 4.4, the contamination halo forms an irregular ellipse, with the longer axis trending in the direction of the prevailing wind. Hence, distances to background also vary slightly in relation to wind direction and strength with respect to the smelter. 
4.6.2 Distribution of trace elements on the forest floor

Humus profile and forest litter samples were collected at 9 sites selected from the regional survey to assess factors influencing metal distribution within the organic horizon and evaluate the significance of the regional humus database (Fig. 4.2). A summary of the results for forest litter and humus samples is presented in Table 4.5 and Fig. 4.6.

Metals are supplied to the humus horizon partly by mixing with mineral matter, biogeochemical cycling, and atmospheric deposition (Steiness and Njåstad, 1993). In the Flin Flon area, distance from the smelter remains the dominant factor influencing the geochemistry of the surface organic horizon. Results indicate that concentrations of smelter elements ( $\mathrm{As}, \mathrm{Cd}, \mathrm{Cu}, \mathrm{Hg}, \mathrm{Pb}, \mathrm{Zn})$ in all layers and fractions of humus, and in forest litter samples, decrease with increasing distance from the smelter, according to the inverse curvilinear relationship of the type $y=a x^{-b}$ (Fig. 4.6).

On a site to site basis however, the relative proportion and composition of the mineral and organic fractions strongly influence the elemental composition of forest organic soils around Flin Flon. Humus varies in total organic content (\%LOI) from 38.2 to $89.6 \%$, and forest litter from 80.4 to $92.8 \%$ (Table 4.5 ). The concentrations of non-smelter related elements (e.g., Al, $\mathrm{Co}, \mathrm{Cr}, \mathrm{Ni}, \mathrm{Fe}$ ) decrease with increasing organic matter content (Table 4.6), indicating these elements reside in the mineral fraction. Varskog et al. (1993) found similar results in Norwegian forest soils and suggested that the organic matter acts as a diluting agent for these elements. In contrast, concentrations of smelter-related metals in all 
Table 4.5 Trace element concentrations in forest litter and bulk humus samples collected in different layers.

Smelter elements

\begin{tabular}{|c|c|c|c|c|c|c|c|c|c|}
\hline \multirow[b]{2}{*}{ Site } & \multirow[b]{2}{*}{$\begin{array}{c}\text { Distance from } \\
\text { smelter }(\mathrm{km})\end{array}$} & \multirow[b]{2}{*}{$\begin{array}{l}\mathrm{LOI} \\
(\%) \\
\end{array}$} & \multicolumn{6}{|c|}{ Smelter elements } & \multirow[b]{2}{*}{$\begin{array}{c}\mathrm{Ni} \\
(\mathrm{ppm}) \\
\end{array}$} \\
\hline & & & $\begin{array}{c}\text { As } \\
\text { (ppm) } \\
\end{array}$ & $\begin{array}{c}\mathrm{Cd} \\
(\mathrm{ppm}) \\
\end{array}$ & $\begin{array}{c}\text { Cu } \\
\text { (ppm) }\end{array}$ & $\begin{array}{c}\mathrm{Hg} \\
(\mathrm{ppb})\end{array}$ & $\begin{array}{c}\mathrm{Pb} \\
\text { (ppm) }\end{array}$ & $\begin{array}{c}\mathrm{Zn} \\
(\mathrm{ppm})\end{array}$ & \\
\hline \multicolumn{10}{|c|}{ Forest litter } \\
\hline 1 & 5 & 86.8 & 18 & 26.5 & 1475 & 12436 & 310 & 6230 & 10 \\
\hline 2 & 10 & 89.2 & 8 & 9.5 & 300 & 2549 & 168 & 1805 & 4 \\
\hline 3 & 16 & 89.6 & 2 & 7.0 & 132 & 225 & 34 & 1020 & 3 \\
\hline 4 & 22 & 80.4 & 2 & 7.5 & 118 & 993 & 70 & 1075 & 6 \\
\hline 5 & 34 & 90.4 & 1 & 4.0 & 46 & 281 & 20 & 328 & 3 \\
\hline 6 & 36 & 83.2 & 1 & 2.0 & 49 & 226 & 36 & 234 & 6 \\
\hline 7 & 40 & 85.4 & 1 & 3.5 & 86 & 566 & 54 & 392 & 4 \\
\hline 8 & 51 & 92.8 & 1 & 0.5 & 13 & 172 & 8 & 90 & 3 \\
\hline 9 & 75 & 92.8 & 2 & 7.5 & 27 & 100 & 16 & 186 & 3 \\
\hline
\end{tabular}

Bulk humus - complete layer

$\begin{array}{cccccccccc}1 & 5 & 69.6 & 72 & 47.0 & 1970 & 3999 & 1370 & 7680 & 7 \\ 2 & 10 & 48.0 & 34 & 16.5 & 773 & 844 & 820 & 1660 & 10 \\ 3 & 16 & 75.4 & 36 & 13.0 & 538 & 2032 & 430 & 2010 & 8 \\ 4 & 22 & 69.0 & 18 & 4.5 & 144 & 465 & 166 & 614 & 9 \\ 5 & 34 & 86.4 & 6 & 2.0 & 54 & 282 & 110 & 186 & 5 \\ 6 & 36 & 80.6 & 6 & 1.5 & 54 & 44 & 58 & 184 & 6 \\ 7 & 40 & 41.0 & 8 & 1.5 & 81 & 260 & 144 & 268 & 17 \\ 8 & 51 & 64.0 & 4 & 1.0 & 34 & 167 & 44 & 62 & 13 \\ 9 & 75 & 78.4 & 6 & 3.0 & 48 & 192 & 56 & 208 & 13\end{array}$

\section{Bulk humus - top layer}

\begin{tabular}{cccccccccc}
1 & 5 & 71.0 & 40 & 37.5 & 1400 & 10297 & 526 & 9700 & 8 \\
2 & 10 & 84.0 & 22 & 23.0 & 789 & 2121 & 412 & 5240 & 8 \\
3 & 16 & 76.6 & 20 & 15.0 & 442 & 2072 & 304 & 2520 & 8 \\
4 & 22 & 76.0 & 10 & 8.5 & 163 & 827 & 134 & 1330 & 7 \\
5 & 34 & 75.8 & 4 & 5.5 & 41 & 418 & 40 & 336 & 6 \\
6 & 36 & 80.4 & 6 & 3.0 & 51 & 87 & 62 & 322 & 7 \\
7 & 40 & 84.4 & 1 & 4.0 & 97 & 317 & 78 & 498 & 5 \\
8 & 51 & 65.6 & 8 & 2.0 & 39 & 284 & 40 & 162 & 15 \\
9 & 75 & 89.6 & 1 & 3.5 & 42 & 100 & 48 & 264 & 6 \\
& & & & & & & & & \\
1 & 5 & 68.0 & 60 & 40.0 & 1835 & 4001 & 1195 & 7380 & 7 \\
3 & 10 & 82.6 & 54 & 15.5 & 810 & 340 & 1140 & 3190 & 6 \\
3 & 16 & 70.0 & 28 & 9.0 & 343 & 1138 & 280 & 1300 & 35 \\
4 & 22 & 76.8 & 28 & 4.5 & 172 & 203 & 302 & 668 & 6 \\
5 & 34 & 60.2 & 8 & 2.5 & 49 & 340 & 78 & 234 & 10 \\
6 & 36 & 86.6 & 8 & 2.0 & 45 & 91 & 62 & 250 & 6 \\
7 & 40 & 38.2 & 10 & 1.5 & 79 & 208 & 116 & 268 & 15 \\
8 & 51 & 55.0 & 8 & 2.5 & 34 & 276 & 66 & 94 & 10 \\
9 & 75 & 79.4 & 8 & 4.0 & 110 & 201 & 102 & 422 & 10 \\
\hline
\end{tabular}


FOREST LITTER

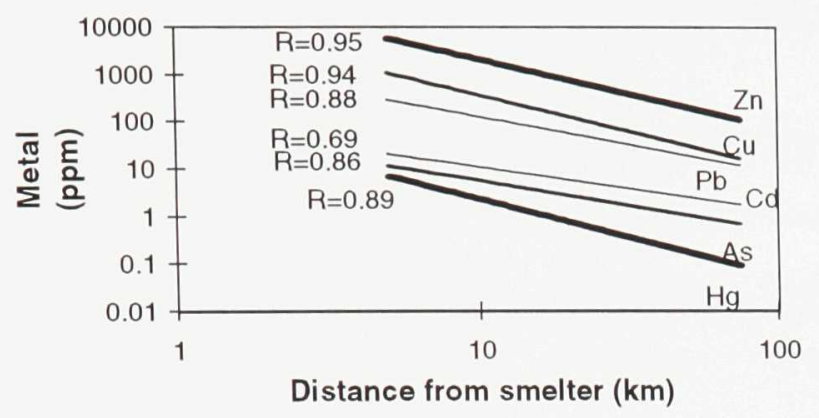

$<0.425 \mathrm{~mm}$ OF HUMUS

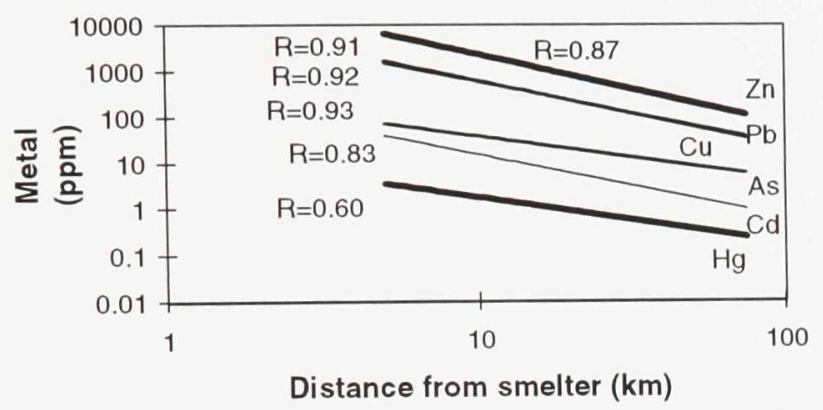

BULK HUMUS

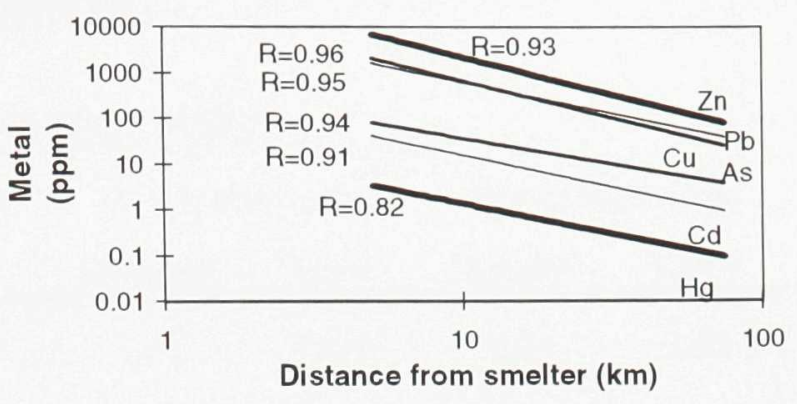

$>0.425 \mathrm{~mm}$ OF HUMUS

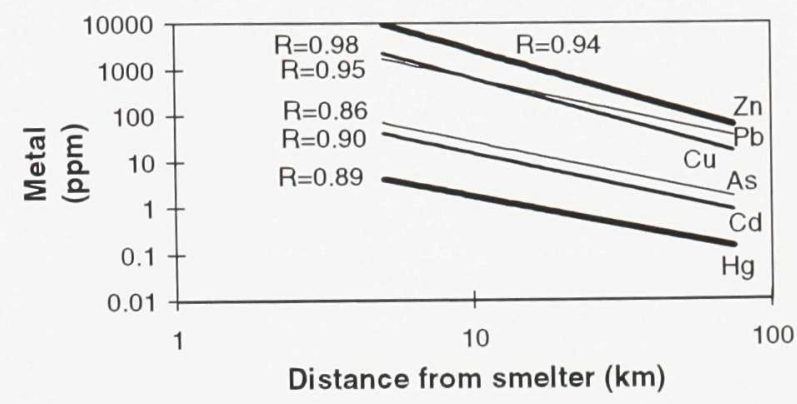

Figure 4.6 Fitted curves and correlation coefficients for major smelter elements in forest litter and different fractions of complete humus layers $(n=9)$. 
Table 4.6 Correlation coefficients "r" between distance from the smelter and \%LOI of organic samples, and selected trace elements.

Humus in complete, top and bottom layers $(n=27)$

\begin{tabular}{ccccccccc} 
& \multicolumn{2}{c}{ Bulk sample } & \multicolumn{2}{c}{$<0.425 \mathrm{~mm}$ fraction } & \multicolumn{2}{c}{$>0.425 \mathrm{~mm}$ fraction } & \multicolumn{2}{c}{ Forest litter $(\mathrm{n}=9)$} \\
& Distance & \% LOI & Distance & \% LOI & Distance & $\%$ LOI & Distance & $\%$ LOI \\
\hline Distance & 1.00 & 0.07 & 1.00 & 0.22 & 1.00 & -0.09 & 1.00 & 0.43
\end{tabular}

\section{Smelter elements}

\begin{tabular}{|c|c|c|c|c|c|c|c|c|}
\hline & \multirow[b]{2}{*}{-0.06} & & \multirow[b]{2}{*}{-0.22} & & \multirow[b]{2}{*}{0.07} & & \multirow[b]{2}{*}{-0.05} \\
\hline As & $-0,74$ & & -0.78 & & -0.73 & & -0.60 & \\
\hline $\mathrm{Cd}$ & $-0,68$ & 0.02 & -0.68 & -0.17 & -0.69 & 0.15 & -0.55 & -0.10 \\
\hline $\mathrm{Cu}$ & $-0,68$ & -0.04 & -0.70 & -0.25 & -0.67 & 0.14 & -0.58 & -0.12 \\
\hline $\mathrm{Hg}$ & -0.53 & -0.01 & -0.55 & -0.24 & -0.69 & 0.14 & -0.56 & -0.12 \\
\hline $\mathrm{Pb}$ & -0.68 & -0.06 & -0.70 & -0.19 & -0.58 & -0.21 & -0.69 & -0.20 \\
\hline $\mathrm{Zn}$ & -0.66 & 0.05 & -0.66 & -0.21 & -0.67 & 0.12 & -0.65 & 0.15 \\
\hline
\end{tabular}

\section{Other elements}

\begin{tabular}{|c|c|c|c|c|c|c|c|c|}
\hline Al & -0.06 & -0.28 & 0.26 & -0.73 & 0.43 & -0.73 & -0.34 & -0.90 \\
\hline Co & -0.53 & -0.41 & -0.56 & -0.55 & -0.38 & .0 .57 & -0.76 & -0.72 \\
\hline $\mathrm{Cr}$ & -0.02 & $-0,66$ & -0.35 & -0.59 & -0.01 & $-0,87$ & -0.14 & -0.37 \\
\hline $\mathrm{Fe}$ & -0.23 & -0.81 & -0.32 & 0.87 & -0.02 & 0.92 & -0.66 & -0.81 \\
\hline $\mathrm{Ni}$ & 0.06 & -0.43 & 0.27 & -0.76 & 0.43 & $=0.80$ & -0.54 & -0.56 \\
\hline
\end{tabular}

\begin{tabular}{|l|l}
\hline & Statistically significant at the $95 \%$ confidence level \\
Statistically significant at the $99 \%$ confidence level
\end{tabular}


fractions of humus and in forest litter samples correlate strongly with distance from the smelter and are unrelated to variations in the total organic content (Table 4.6).

Based on sequential extraction analysis, Henderson et al. (1998) found that $\mathrm{Zn}, \mathrm{Pb}$, $\mathrm{Cd}$ and $\mathrm{Cu}$ are held primarily in an easily leachable (labile) form, mostly in the soluble organic phase of humus (humic and fulvic complexes), while $\mathrm{Hg}$ and $\mathrm{As}$ are largely associated with the non-labile phases (humin and mineral matter), hence are less mobile than the other smelter metals. Concentrations of the smelter elements held in the non-labile phases were also found to decrease in proportion to the other phases with distance from the smelter. This suggests that smelter element contents are strongly influenced by the composition of the organic fraction and by the presence of smelter particles in the mineral matter fraction.

Trace element concentrations on the forest floor are also influenced by the state of decomposition of the organic material, as expressed by variations in the depth of sampling of the organic rich horizon (Table 4.5). At all sampling sites except one (site 6), the organic matter content decreases with increasing depth indicating increased mixing with mineral soil. Most trace elements increase in concentration from the poorly decomposed forest litter layer, to the better decomposed humus layer, where humic substances are concentrated. Humic substances are well known to form stable metal-organic associations (Stevenson, 1994). The abundance of humic substances in the humus layer probably controls the mobility of the smelter-related elements on the forest floor since total concentrations do not vary with 
mineral matter content (cf. Table 4.6).

\subsubsection{Significance of the regional humus database}

To assess the proportion of total smelter emissions represented by the regional dispersal patterns in humus, the significance of the regional humus database for total metal concentrations on the forest floor needs to be evaluated. Table 4.7 presents additional results from the detailed sampling program. The $<0.425 \mathrm{~mm}$ fraction of humus represents an average of $41.65 \%$ by weight of the dry bulk humus. It also accounts for an average of $48.2 \%$ of total smelter element concentrations in the humus layer, varying from $41.92 \%$ for $\mathrm{Pb}$ to $58.66 \%$ for As (Table 4.7). Most regional humus samples were collected in the bottom humus layer, and the ratios of element concentrations in the $<0.425 \mathrm{~mm}$ of humus to those in the bulk fraction vary with distance from the smelter and between elements, averaging 1.14 for the major smelter elements. Therefore, the fine fraction of humus, used in the regional study, has a similar element content to the coarse fraction, and to the bulk (Fig. 4.6), and represents a good approximation of humus composition. The thickness, bulk density and \% LOI of humus also vary throughout the area, but regionally, do not affect humus geochemistry as much as distance from the smelter. The \%LOI of humus correlates positively $(r=0.64)$ with thickness and negatively $(r=-0.63)$ with bulk density (Table 4.7$)$, suggesting that mixing with mineral soil increases where the humus layer is thin. Forest litter also contains elevated element concentrations that decrease away from the smelter, and an evaluation of total smelter metal content in the organic rich layer of forest soils necessitates an examination of the litter fall. 
Table 4.7 Relative proportion of smelter elements contained in $<0.425 \mathrm{~mm}$ fraction to total smelter element concentrations in complete bulk humus layer.

$\% \quad$ Proportion of smelter elements (\%)

\begin{tabular}{ccccccccccc} 
& & \multicolumn{4}{c}{ Proportion of smelter elements (\%) } & \multicolumn{5}{c}{ Thickness Bulk density } \\
\cline { 3 - 8 } Site & (dry wt.) & $\mathrm{As}$ & $\mathrm{Cd}$ & $\mathrm{Cu}$ & $\mathrm{Hg}$ & $\mathrm{Pb}$ & $\mathrm{Zn}$ & $(\mathrm{cm})$ & $\left(\mathrm{g} / \mathrm{cm}^{3}\right)$ & $\%$ LOI \\
\hline 1 & 44.37 & 54.58 & 45.82 & 41.05 & 54.81 & 38.79 & 43.12 & 5 & 0.12 & 69.4 \\
2 & 42.34 & 48.67 & 43.93 & 45.09 & 50.21 & 40.73 & 39.43 & 5 & 0.11 & 48.0 \\
3 & 24.38 & 27.91 & 24.88 & 23.25 & 21.17 & 26.63 & 23.02 & 9 & 0.13 & 75.4 \\
4 & 43.10 & 58.08 & 40.25 & 48.48 & 47.42 & 51.03 & 39.57 & 5 & 0.15 & 69.0 \\
5 & 33.98 & 83.87 & 38.43 & 44.52 & 27.23 & 47.65 & 38.18 & 7 & 0.12 & 86.4 \\
6 & 37.84 & 31.48 & 55.06 & 31.26 & 6.55 & 29.68 & 38.63 & 6 & 0.11 & 80.6 \\
7 & 59.14 & 64.64 & 42.24 & 70.34 & 76.82 & 27.85 & 66.65 & 4 & 0.18 & 41.0 \\
8 & 49.60 & 85.69 & 49.94 & 77.56 & 87.39 & 65.66 & 67.19 & 7 & 0.12 & 64.0 \\
9 & 40.10 & 72.97 & 51.91 & 62.06 & 71.45 & 49.28 & 64.52 & 7 & 0.09 & 78.4 \\
Average & 41.65 & 58.66 & 43.61 & 49.29 & 49.23 & 41.92 & 46.70 & 6.1 & 0.13 & 68.0 \\
\hline
\end{tabular}
Thickness Bulk density 


\subsubsection{Geochemical composition of C-horizon till}

Regional geochemical data and proportional dot maps showing concentrations of elements in the $<0.002 \mathrm{~mm}$ and the $<0.063 \mathrm{~mm}$ fractions of till collected in the Flin Flon region are available in Henderson (1995a) and McMartin et al. (1996). Geochemical maps indicate that heavy metal concentrations vary with bedrock composition. They are low over Paleozoic bedrock, and elevated on or down-ice from naturally enriched Precambrian lithologies. The proportional dot maps of $\mathrm{Cu}, \mathrm{Zn}$, As and $\mathrm{Ni}$ in the clay fraction of till show that till sampled over rocks of the Flin Flon Belt is enriched, compared to till over the Kisseynew Domain (Fig. 4.7). Trace and major element background concentrations in the clay-sized fraction of till, as defined by the median value, were calculated and are summarized in Table 4.8, on the basis of the underlying bedrock lithology. Background concentrations and geochemical maps indicate that till derived from felsic intrusive lithologies is depleted in most trace metals, particularly in $\mathrm{Zn}, \mathrm{Cu}$, and $\mathrm{Ni}$, with respect to other Shield derived till. Till derived from felsic volcanics is naturally enriched in $\mathrm{Zn}$ and $\mathrm{Cu}$, and till overlying Paleozoic bedrock has a moderate to high carbonate content, and high $\mathrm{Ca}$ and Mg concentrations, but low trace metal concentrations. McMartin et al. (1996) concluded that the geochemistry of till in the Flin Flon area is influenced primarily by the composition and nature of the underlying bedrock, modified by the effects of glacial erosion, transport and deposition. The effects of weathering and surface contamination is minimized by sampling below the zone of maximum B-horizon development. 

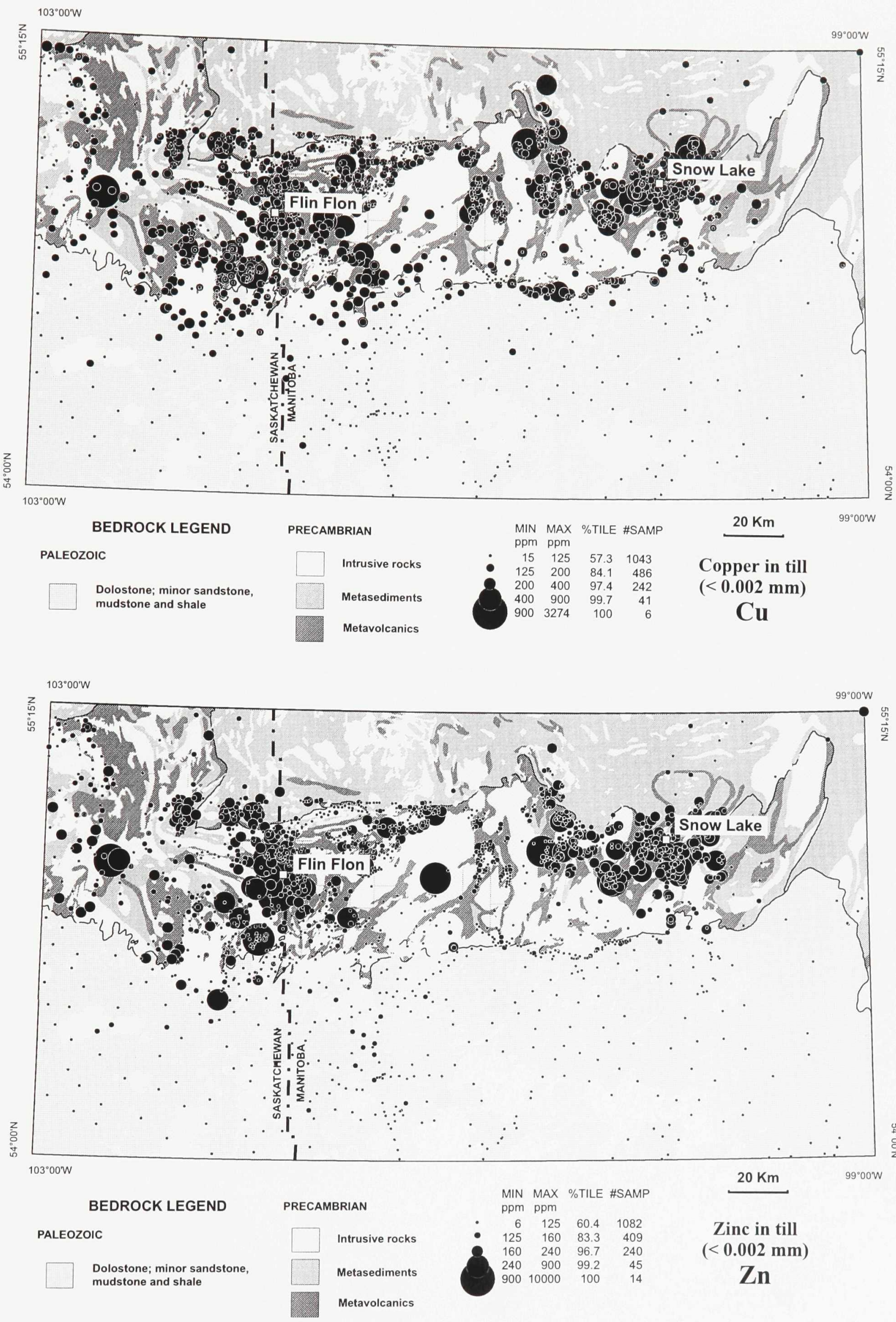

Figure 4.7 Regional distribution of selected elements in the $<0.002 \mathrm{~mm}$ fraction of till over simplified bedrock map. (a) $\mathrm{Cu}$ and $\mathrm{Zn}$ in till. 

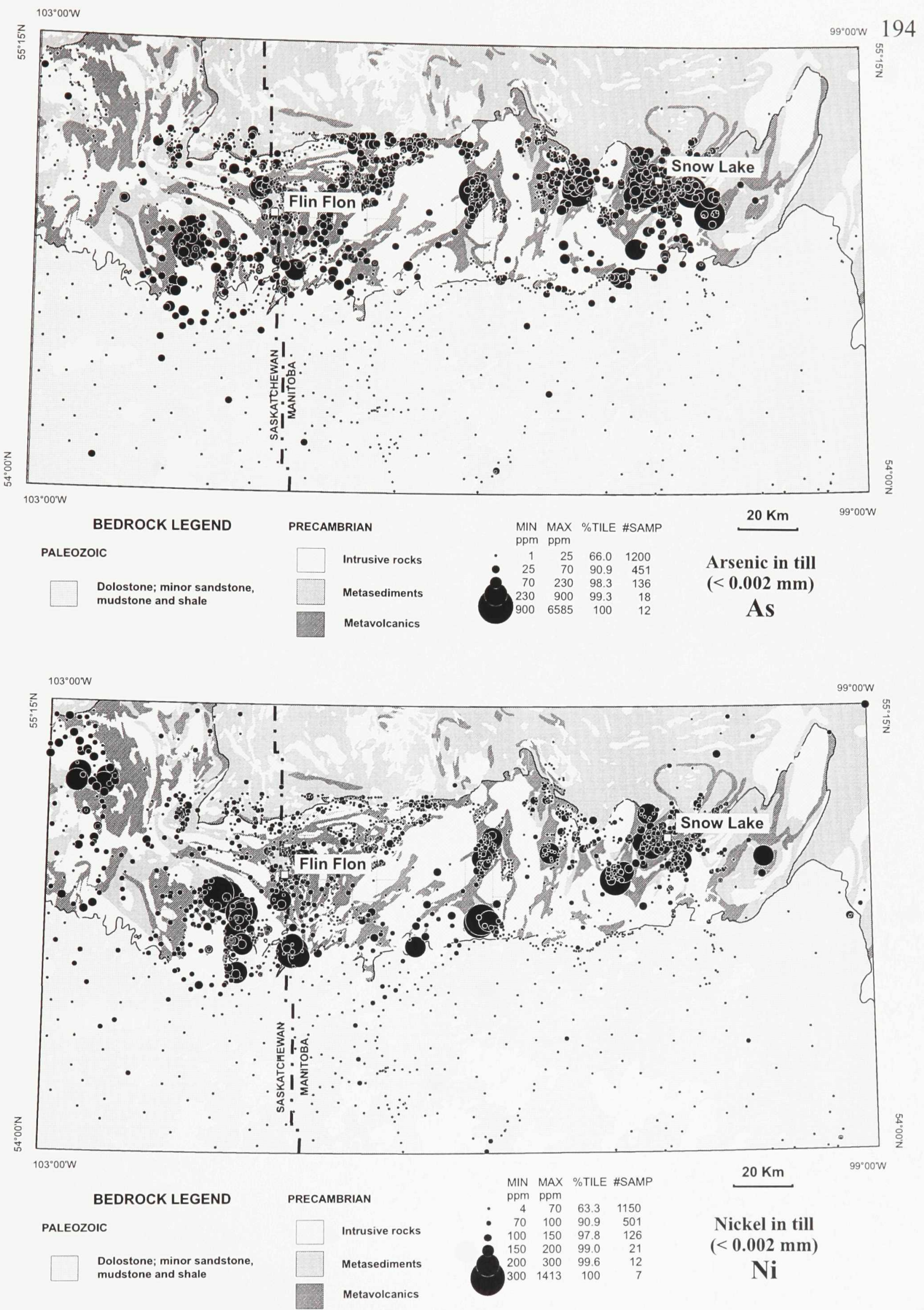

(b) As and Ni in till. 
Table 4.8 Background concentrations in till $(<0.002 \mathrm{~mm})$ as a function of underlying bedrock.

\begin{tabular}{|c|c|c|c|c|c|c|c|c|c|}
\hline \multirow[b]{3}{*}{ Element } & \multirow{3}{*}{$\begin{array}{c}\text { All samples } \\
(n=1817)\end{array}$} & \multirow{3}{*}{$\begin{array}{l}\text { Samples underlain } \\
\text { by Paleozoic } \\
(n=451)\end{array}$} & \multicolumn{7}{|c|}{ Samples underlain by Precambrian bedrock } \\
\hline & & & \multirow{2}{*}{$\begin{array}{c}\text { Total } \\
(n=1366)\end{array}$} & \multicolumn{2}{|c|}{ Volcanics } & \multicolumn{2}{|c|}{ Sediments } & \multicolumn{2}{|c|}{ Intrusive } \\
\hline & & & & Felsic & Mafic & Schists & Gneiss & Felsic & Mafic \\
\hline \multicolumn{10}{|c|}{ Smelter elements } \\
\hline As (ppm) & 16 & 6 & 20 & 30 & 20 & 18 & 18 & 20 & 22 \\
\hline $\mathrm{Cd}(\mathrm{ppm})$ & 0.3 & 0.3 & 0.3 & 0.5 & 0.3 & 0.3 & 0.5 & 0.3 & 0.3 \\
\hline $\mathrm{Cu}(\mathrm{ppm})$ & 111 & 67 & 122 & 143 & 134 & 119 & 125 & 106 & 133 \\
\hline $\mathrm{Hg}(\mathrm{ppb})$ & 50 & 50 & 40 & 40 & 40 & 40 & 30 & 50 & 50 \\
\hline $\mathrm{Pb}(\mathrm{ppm})$ & 6 & 4 & 8 & 10 & 6 & 10 & 12 & 8 & 8 \\
\hline $\mathrm{Zn}(\mathrm{ppm})$ & 116 & 80 & 124 & 142 & 122 & 134 & 138 & 116 & 128 \\
\hline
\end{tabular}

\section{Non smelter elements}

$\begin{array}{llllllllll}\mathrm{Cr}(\mathrm{ppm}) & 125 & 97 & 135 & 119 & 139 & 144 & 135 & 127 & 136 \\ \mathrm{Ni}(\mathrm{ppm}) & 62 & 49 & 67 & 69 & 67 & 68 & 73 & 63 & 67\end{array}$

\section{Major elements}

$\begin{array}{llllllllll}\mathrm{Ca}(\%) & 0.40 & 6.85 & 0.32 & 0.36 & 0.36 & 0.26 & 0.25 & 0.29 & 0.41 \\ \mathrm{Fe}(\%) & 5.60 & 3.78 & 5.88 & 6.28 & 5.88 & 6.08 & 6.05 & 5.67 & 5.64 \\ \mathrm{Mg}(\%) & 2.09 & 4.07 & 1.89 & 2.00 & 1.93 & 1.86 & 1.91 & 1.74 & 2.07\end{array}$

Carbonate in $<0.063 \mathrm{~mm}$ fraction

\begin{tabular}{llllllllll} 
Total $\mathrm{CO}_{3}:$ & 3.19 & 38.59 & 2.46 & 3.45 & 2.57 & 2.44 & 2.21 & 2.17 & 4.02 \\
\hline
\end{tabular}


4.6.4 Vertical distribution of heavy metals in soil profiles

Six till sections were examined to characterize regional weathering processes, and the possible extent of downward leaching of surface smelter contamination (Fig. 4.2). The sections vary from 9 to $125 \mathrm{~km}$ in distance from the smelter. The complete data are reported in McMartin et al. (1996). Figure 4.8 shows trace and major element concentrations measured at various depths in 3 selected profiles. Sections A (9 km), B (14 km) and D (125 $\mathrm{km}$ ) consist of a single sandy non-calcareous till unit, overlying volcanic and sedimentary rocks of the Flin Flon Belt.

Brunisolic soils are the most common soils developed on Precambrian terrain in the area, and occur mainly on well drained surficial deposits, including non-calcareous sandy tills (Acton and Padbury, 1984). Brunisols are characterized by poorly developed podzolic B-horizons (Bm), slightly weathered by oxidation and with little illuviated material (clay, Fe, $\mathrm{Al}$, organic matter). In Sections $\mathrm{A}, \mathrm{B}$ and $\mathrm{D}$, the $\mathrm{B}$ horizon occurs above approximately 50 $\mathrm{cm}$, based on total Fe content, the organic matter accumulation, and the slight change in color caused by the oxidation of Fe.

In Section A ( Fig. 4.8), humus is highly contaminated, and concentrations of most smelter metals are enriched in the B-horizon of till (up to $8 \mathrm{x}$ ) relative to the underlying $\mathrm{C}$ horizon, reaching regional background concentrations at or slightly above the maximum depth of B-horizon development $(45 \mathrm{~cm})$. Non-smelter related elements (e.g., Ni) are depleted both in humus and in the B-horizon material relative to the C-horizon, and stabilize 
A

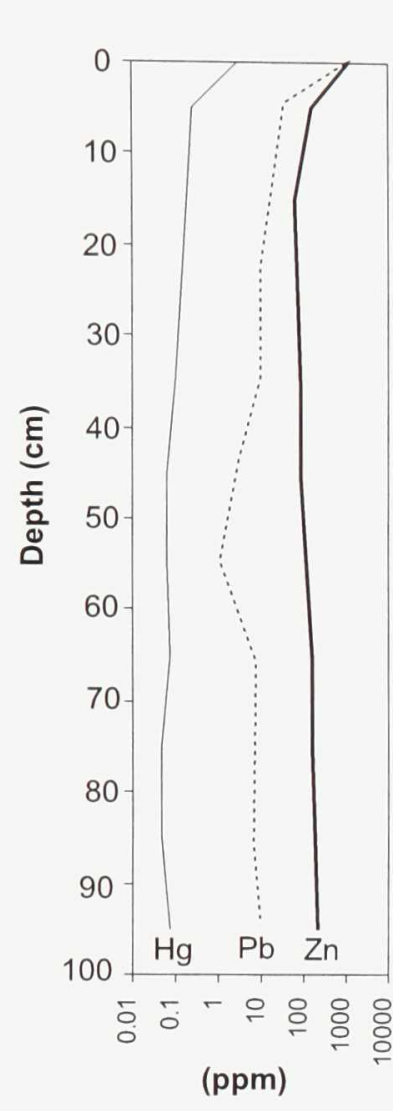

B

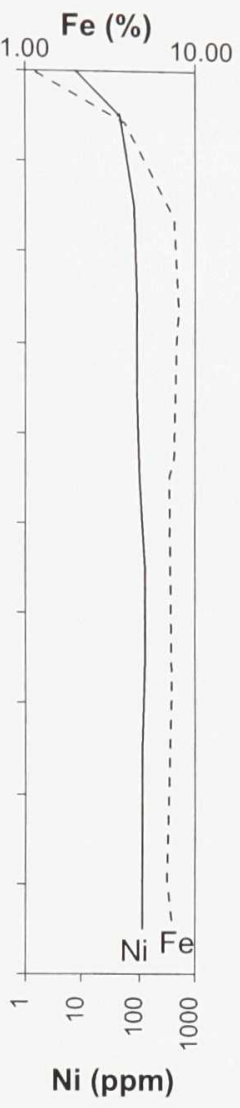

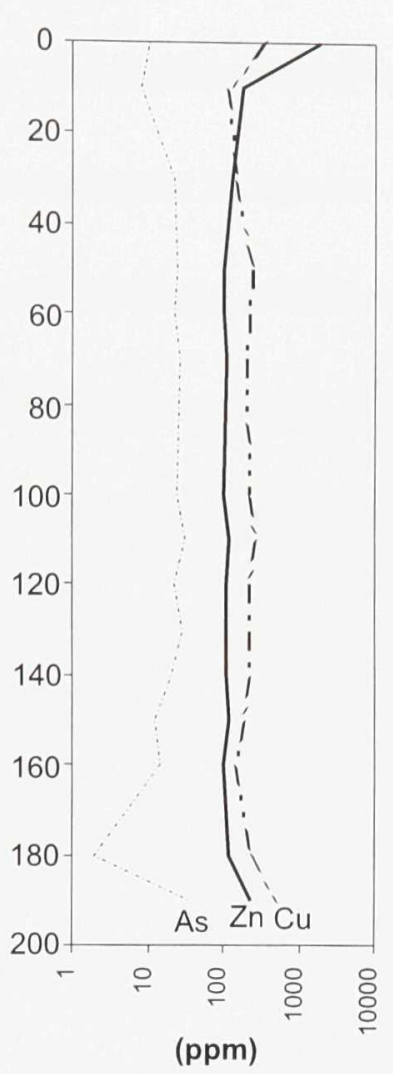

D $\quad \mathrm{Fe}(\%)$

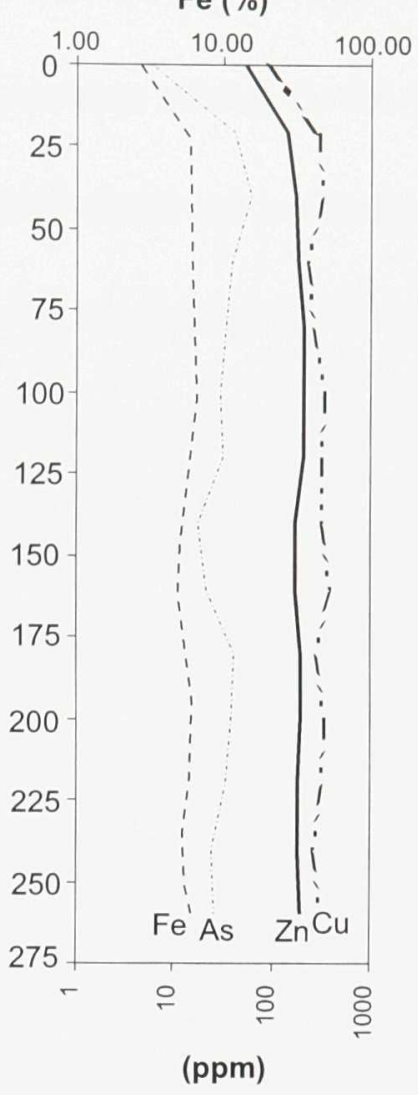

Figure 4.8 Vertical distribution of selected trace and major elements in the $<0.002$ $\mathrm{mm}$ fraction of till measured in Sections A ( $9 \mathrm{~km}$ from the smelter), B ( $14 \mathrm{~km})$, and D $(125 \mathrm{~km})$. Samples collected at $0 \mathrm{~cm}$ depth consist of humus $(<0.425 \mathrm{~mm})$. Note logarithmic concentration scale. 
in the upper C-horizon. Samson (1986) also observed increasing $\mathrm{Ni}$ and $\mathrm{Cr}$ concentrations with depth in till sections around Flin Flon, and smelter metal enrichments at least down to 10-15 cm depth. Therefore, the relative enrichment in smelter metals observed in the Bm horizon of Section A suggests that downward leaching of those metals may occur to $45 \mathrm{~cm}$ depth at highly contaminated sites ( $<10 \mathrm{~km}$ from the smelter). Chemical partitioning studies on the $<0.002 \mathrm{~mm}$ fraction of till in the same section suggest downward leaching of $\mathrm{Zn}$ and $\mathrm{Hg}$ to $25 \mathrm{~cm}$ depth (Henderson et al., 1998). At extremely contaminated sites $(<3 \mathrm{~km})$, these authors found increased percentages of smelter-related elements in labile phases of C-horizon till that they related primarily to downward leaching from the humus layer, although elevated concentrations may also be influenced by weathering of metal-bearing sulphides associated with the mineralization near Flin Flon.

Smelter elements in Sections B $(14 \mathrm{~km})$ and C $(49 \mathrm{~km})$ have similar distribution patterns down the soil profile (McMartin et al., 1996). In section B (Fig. 4.8), humus is relatively enriched in smelter elements with respect to regional background concentrations. In both sections, concentrations of most trace metals are depleted in the B-horizon, and stabilize or increase slightly in the C-horizon. Only $\mathrm{Zn}$ is definitively enriched in the Bhorizon (1.5x) in Section B, down to $30 \mathrm{~cm}$ depth, relative to the underlying $\mathrm{C}$-horizon. This suggests that sub-surface contamination is not significant at sites beyond $10 \mathrm{~km}$ from the smelter, with the exception of $\mathrm{Zn}$, which may be leached into the B-horizon at sites with moderately contaminated humus $(<25 \mathrm{~km})$. 
Section D is located near Snow Lake, an area naturally enriched in $\mathrm{Cu}$ and $\mathrm{Zn}$ (Fig. 4.8), and lies beyond the maximum radius of smelter contamination in humus. All metal concentrations in the B-horizon are depleted or stable relative to the underlying C-horizon. Kaszycki et al. (1996) also observed similar metal-depleted B-horizon soils in the Snow Lake area, and suggested that trace metals released by oxidation of sulphides remain in solution and are transported to the water table. Therefore, at distances greater than $100 \mathrm{~km}$ from the smelter stack, both surface and sub-surface metal contamination appear to be insignificant, or unrecognizable from natural soil-forming processes.

\subsection{Discussion}

Humus is enriched in trace and major elements through different processes, including atmospheric deposition and uptake in plant roots of elements derived from natural and anthropogenic sources, with the subsequent return to the organic layers by decay of plant material (Stevenson, 1994). In the Flin Flon area, humus is enriched in those elements emitted from the smelter, and regional dispersal patterns reflect the historical record of smelter contamination. On a regional basis, the major factors controlling the distribution of heavy metals in humus are distance from the smelter stack and prevailing wind direction. Differences in the patterns of surface contamination among smelter-related elements result primarily from variations in the composition of the emissions, the airborne behaviour of the metal particulates, and the stability of the metals in humus. On a site-to-site basis, other variables may influence the retention and distribution of trace elements in humus, such as the composition of underlying substrate, total organic content, state of decomposition, and 
composition of the humus layer.

Average distances to regional background in humus vary in the order $\mathrm{Cd}<\mathrm{Pb}<\mathrm{Zn}<\mathrm{Hg}<\mathrm{Cu}<\mathrm{As}$, from 70 to $104 \mathrm{~km}$. In the Flin Flon area, the recognizable smelter contamination zone extends slightly further in the predominant southeasterly downwind direction. The method used here to estimate the maximum radius of contamination contains limitations, but represents a realistic approximation of the regional extent of smelter contamination in soils. The regional background value determined for each of the smelterrelated elements in the $<0.425 \mathrm{~mm}$ fraction of humus was used to calculate the maximum area receiving smelter-derived particulate emissions. The background values vary among elements and according to the underlying bedrock type (cf. Table 4.4). Regionally, the background values in humus follow the order $\mathrm{Zn}>\mathrm{Pb}>\mathrm{Cu}>\mathrm{As}>\mathrm{Cd}>\mathrm{Hg}$, similar to the order found in the historical smelter emissions (cf. Table 4.1), and probably reflect the average composition of the bedrock in the area. Background levels also vary significantly among sample mediums and size fractions examined in this study, reflecting the differences in the nature and relative proportion of the substances active in metal bonding.

The differences in the slopes of the decay curves among the smelter elements (Fig. 4.5) document the airborne behaviour of the metal particles and the resulting deposition velocity. In the Flin Flon area, the curves derived from the equation $y=a x^{-b}$ are characterized by an extremely rapid decline in their upper portion, flattening after only 15 to $20 \mathrm{~km}$ from the source. This trend is typical of atmospheric fallout, where particulate emissions from 
dispersal plumes fall rapidly by dry and wet deposition (Davies, 1983). The slope of the decay curves varies and follows the order $\mathrm{Zn}>\mathrm{Cu}>\mathrm{Cd}>\mathrm{Pb}>\mathrm{As}>\mathrm{Hg}$. The most volatile smelter elements $(\mathrm{Hg}, \mathrm{As}, \mathrm{Cd}, \mathrm{Pb})$ have the lowest decay slopes, indicating that these elements are transported farther in air before being deposited. This suggests that the shape, the size and the density of the metal particles influence the airborne behaviour and removal mechanisms of the metals, hence their depositional patterns in the environment. Henderson et al. (1998) observed relationships among size, composition and distance from the smelter of spherical particles in humus, indicating density sorting of particles from the smelter stack. However, the order of maximum radius of contamination suggests that, once the emitted particles reach the forest floor, they are submitted to soil forming processes that further control their enrichment and stability in the receptor environment.

The abundance of metals in the $<0.425 \mathrm{~mm}$ fraction of humus is in the order $\mathrm{Zn}>\mathrm{Cu}=\mathrm{Pb}>\mathrm{As}>\mathrm{Cd}>\mathrm{Hg}$, defined from direct comparison between the decay curves (Figs. 4.5 and 4.6). This order is in general agreement with the order found in the historic record of smelter emissions (cf. Table 4.1) and in the regional background levels of humus (cf. Table 4.3). However, smelter element ratios in humus are significantly different from those in the historical emissions, and do not vary as a function of distance from the smelter. The nature of these differences is probably the net result of atmospheric fallout and removal mechanisms, as seen above, and soil-forming processes, including enrichment in the surface organic layer and migration of metals down the soil profile. Enrichment factors in humus, calculated here as the ratio between the maximum value and the background value of the 
element, follow the order $\mathrm{Hg}>\mathrm{As}>\mathrm{Cu}>\mathrm{Zn}>\mathrm{Cd}>\mathrm{Pb}$, from $526 \mathrm{x}$ to $76 \mathrm{x}$. This order is directly opposite to the metal mobilities in humus, determined from the average relative proportion of smelter elements associated with labile phases of humus (Henderson et al., 1998). As an example, the predominance of $\mathrm{Pb}$ over $\mathrm{Cu}$ in the stack dusts (cf. Table 4.1) is not observed in humus or till, possibly because $\mathrm{Pb}$ is held in more labile phases than $\mathrm{Cu}$ (Henderson et al., 1998) and, hence, more likely to be mobilized and transported by groundwater.

\subsection{Environmental implications}

A regional zoning of smelter contamination can be defined, based on total metal concentrations in the $<0.425 \mathrm{~mm}$ fraction of humus of all samples and in the $<0.002 \mathrm{~mm}$ fraction of till in soil profiles (Table 4.9 and Fig. 4.9). Zone A (0-4 km) covers a small area around Flin Flon but has anomalous concentrations (98 to $100 \%$ tile) of smelter elements on the forest floor, reaching up to 526x the regional background in the case of $\mathrm{Hg}$ in humus, and $223 \mathrm{x}$ in the case of As. Sub-surface enrichment of smelter elements may also occur at depth in these soils, particularly in well-drained sediments or where the surface organic layer is thin. Smelter element concentrations in Zone B (4-10 km) lie within the 90-98 \%tile of all humus samples, up to $72 \mathrm{x}$ the regional background in $\mathrm{Cu}$ and $67 \mathrm{x}$ in $\mathrm{Zn}$. Downward leaching of smelter elements in soils may occur to $45 \mathrm{~cm}$ depth in this zone. The surface organic rich layer of Zone C (10-25 km) is moderately contaminated, mostly in $\mathrm{Zn}$ (18x the background) and $\mathrm{Cu}(17 \mathrm{x})$. Downward leaching is minimal, except maybe for $\mathrm{Zn}(<30 \mathrm{~cm})$. Low surface contamination occurs in Zone D $(25-50 \mathrm{~km})$, with nearly equal enrichment ratios in all smelter elements (up to $6 x$ ). Finally, in Zone E, very low (2x the background) to no surface 
Table 4.9 Smelter impact zones based on \%tile of smelter elements in humus $(<0.425 \mathrm{~mm}$ fraction $)$.

\begin{tabular}{cccccc} 
& Zone A & Zone B & Zone C & Zone D & Zone E \\
\hline \%tile & 98 to $100 \%$ & 90 to $98 \%$ & 75 to $90 \%$ & 50 to $75 \%$ & backg. to $50 \%$ \\
sub-surface leaching & $>45 \mathrm{~cm}$ & $<45 \mathrm{~cm}$ & Zn: $<30 \mathrm{~cm}$ & none & none \\
range of zone & $0-4 \mathrm{~km}$ & $4-10 \mathrm{~km}$ & $10-25 \mathrm{~km}$ & $25-50 \mathrm{~km}$ & $50-85 \mathrm{~km}$
\end{tabular}

\section{Maximum enrichment ratios ${ }^{a}$}

$\begin{array}{cccccc}\text { As } & 223.2 & 33.6 & 13.2 & 5.6 & 2.4 \\ \mathrm{Cd} & 92.5 & 36.5 & 10.0 & 4.0 & 1.5 \\ \mathrm{Cu} & 191.0 & 71.5 & 16.9 & 5.1 & 1.8 \\ \mathrm{Hg} & 526.3 & 19.0 & 5.8 & 2.8 & 1.6 \\ \mathrm{~Pb} & 75.9 & 29.3 & 10.0 & 3.9 & 1.6 \\ \mathrm{Zn} & 165.5 & 67.0 & 18.0 & 5.4 & 2.0 \\ \text { Average } & 213 \mathrm{x} & 43 \mathrm{x} & 12 \mathrm{x} & 5 \mathrm{x} & 2 \mathrm{x}\end{array}$

\section{Maximum radius $(\mathbf{k m})^{b}$}

$\mathrm{As}$
$\mathrm{Cd}$
$\mathrm{Cu}$
$\mathrm{Hg}$
$\mathrm{Pb}$
$\mathrm{Zn}$

3

4

7

18

$$
42
$$

104

4

11

24

27

51

70

3

12

27

58

90

4

10

23

51

85

4

11

26

49

76

Average

\section{Maximum anthropogenic}

proportions (\%) ${ }^{c}$

\begin{tabular}{cccccc} 
As & 99.6 & 97.0 & 92.4 & 82.1 & 58.3 \\
$\mathrm{Cd}$ & 98.9 & 97.3 & 90.0 & 75.0 & 33.3 \\
$\mathrm{Cu}$ & 99.5 & 98.6 & 94.1 & 80.4 & 44.4 \\
$\mathrm{Hg}$ & 99.8 & 94.7 & 82.7 & 64.8 & 36.7 \\
$\mathrm{~Pb}$ & 98.7 & 96.6 & 90.0 & 74.6 & 39.3 \\
$\mathrm{Zn}$ & 99.4 & 98.5 & 94.5 & 81.5 & 51.2 \\
Average & $99.3 \%$ & $97.1 \%$ & $90.6 \%$ & $76.4 \%$ & $43.9 \%$ \\
\hline
\end{tabular}

\footnotetext{
${ }^{a}$ Calculated as ratio of maximum value in each zone to regional background value

${ }^{b}$ Using concentrations from \%tiles defined in each zone and regression trendlines defined for each element

${ }^{\circ}$ Calculated as [(maximum value-background value)/maximum value] ${ }^{*} 100$
} 


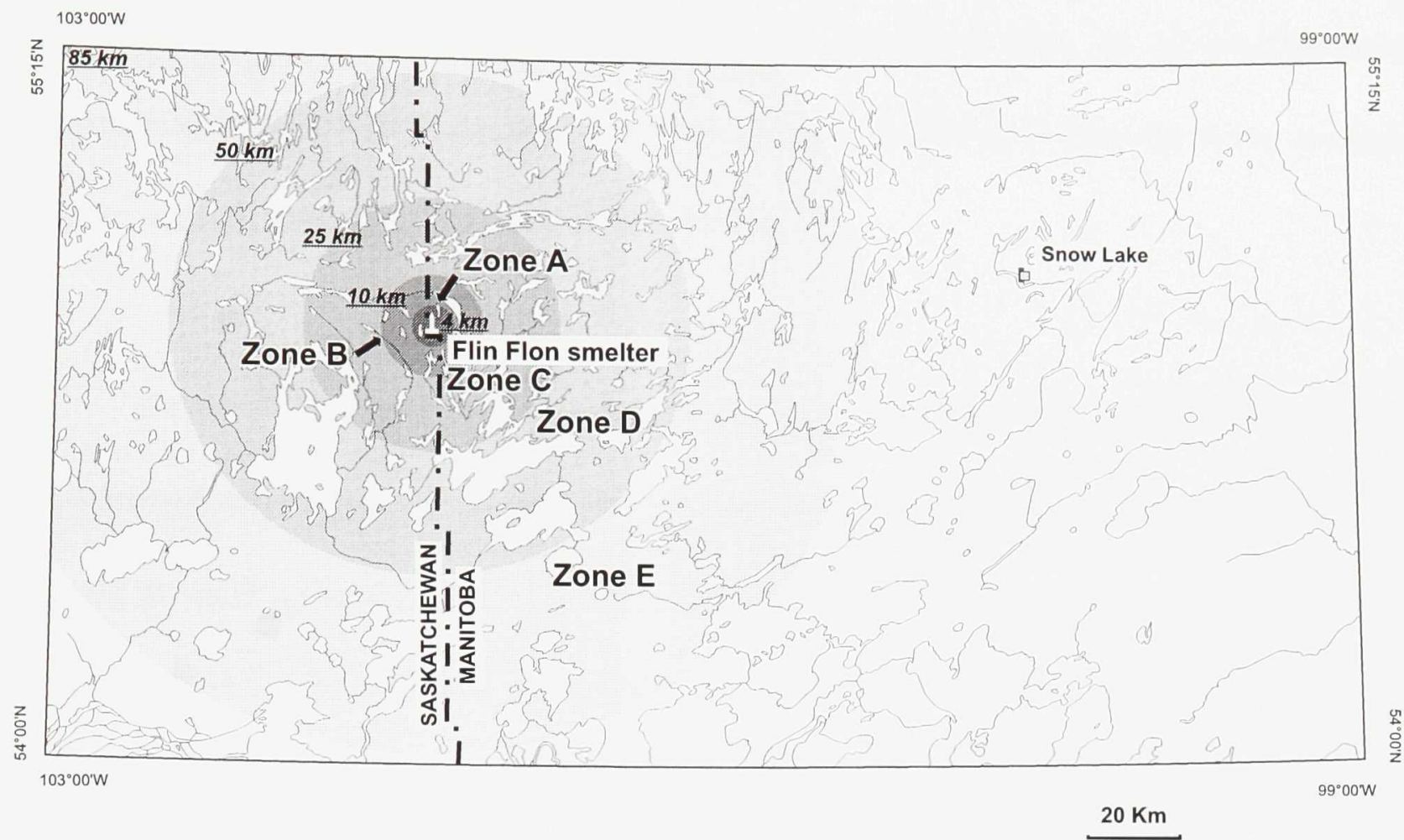

Figure 4.9 Smelter impact zones defined on the basis of total smelter element concentrations in the $<0.425 \mathrm{~mm}$ fraction of humus. 
contamination occurs in all smelter elements on the forest floor, in an area between approximately $50 \mathrm{~km}$ from the stack and a radius defined for each element as the average background distance, varying from 70 to $104 \mathrm{~km}$.

Based on the regional dispersal patterns of smelter elements in soils and the natural background values determined for humus, the relative proportion of element concentrations related to smelter contamination can be approximated in each of the smelter impact zones. In the $<0.425 \mathrm{~mm}$ fraction of humus, the relative proportions associated with an anthropogenic origin decrease away from the smelter, with the maximum percentages averaging $99.3 \%, 97.1 \%, 90.6 \%, 76.4 \%$ and $43.9 \%$ in zones A to E respectively (Table 4.9 ). These anthropogenic proportions vary depending on the element, and they are calculated on the assumption that background concentrations represent the natural component of the metal concentrations. However, to assess the total content of smelter elements on the forest floor, and the proportion of total smelter emissions represented by the well-defined dispersal patterns, a mass-balance of the smelter emissions is needed (Bonham-Carter and McMartin, 1997). The data presented here will help to determine the potential for long-range transport of smelter particles.

\subsection{Conclusions}

Elevated concentrations of $\mathrm{Zn}, \mathrm{Cu}, \mathrm{Pb}, \mathrm{As}, \mathrm{Cd}$ and $\mathrm{Hg}$ occur in the surface organic rich layer of forest soils in the vicinity of the Flin Flon smelter. Total smelter element concentrations decline in all fractions and layers of humus, and in the forest litter, with 
increasing distance from the smelter, and are independent of the total organic content within the recognized contaminated zone. The log-concentrations of these elements decrease linearly with increasing log-distance from the stack, until background values are reached, indicating atmospheric fallout from the smelter plume. Smelter contamination is generally restricted to the surface organic rich horizons, and concentrations of smelter elements in till are poorly correlated with those in the overlying humus, reflecting the absence of smelter contamination at depth in till collected in the upper C-horizon of soils. However, at highly contaminated sites $(<10 \mathrm{~km}$ from smelter $)$, smelter elements migrate down the soil profile, at least to $45 \mathrm{~cm}$ depth. With increasing distance from the smelter, the extent of surface and sub-surface contamination becomes more difficult to estimate. Confounding factors include the natural variations in the geochemistry of the underlying substrate related to bedrock geology, natural soil forming processes, such as biogeochemical cycling and postdepositional mobilization, and the variations in total element concentrations among the different fractions and types of samples analysed. The variations in the maximum radius of contamination among the major smelter elements reflect these complexities of interpretation; distance to background is greater in the predominant wind direction to the SE but averages $104 \mathrm{~km}$ for As, $90 \mathrm{~km}$ for $\mathrm{Cu}, 85 \mathrm{~km}$ for $\mathrm{Hg}, 84 \mathrm{~km}$ for $\mathrm{Zn}, 76 \mathrm{~km}$ for $\mathrm{Pb}$, and $70 \mathrm{~km}$ for $\mathrm{Cd}$.

To evaluate total anthropogenic metal contents in soils, background values in humus must be distinguished from total metal concentrations. Near Flin Flon, humus is naturally elevated in As and five heavy metals with concentrations significantly augmented by the anthropogenic source. In addition, mass-balance studies of the Flin Flon smelter emissions 
must consider that the elements contained in the $<0.425 \mathrm{~mm}$ of humus represent only a fraction of the total element concentrations on the forest floor. 


\section{CHAPTER V: THE CHEMICAL AND PHYSICAL CHARACTERISTICS OF HEAVY METALS IN HUMUS AND TILL}

(a paper published in Environmental Geology, by P.J. Henderson, I. McMartin, G.E. Hall, J.B. Percival, and D.A. Walker; 1998, Vol. 34, No. 1, p. 39-58)

\subsection{Introduction}

Interest in the distribution of heavy metals in soils is based on environmental concerns associated with the effects of high concentrations on human and animal health. Variations in the abundance of these metals in the surficial environment can be related to both natural and anthropogenic sources (Kabata-Pendias and Pendias, 1983; Rasmussen, 1996). Distinguishing between these two sources is difficult; however, the information is essential for the formulation of realistic industrial emission standards and environmental controls. One method of addressing the problem is to examine the chemical and physical signature of heavy metals in areas where anthropogenic emission is known as the primary source of metal enrichment. In this paper, the extent and nature of heavy metal distribution will be examined in soils affected by smelter contamination.

Metal smelters and thermal electric plants are well known as point sources of heavy metal contamination with metals emitted from these facilities decreasing in concentration with distance from the source (Davies, 1983). This distribution pattern has been mapped in foliage, and organic and surface mineral soils of forested areas (Freedman and Hutchinson, 1980; Hogan and Wotton, 1984); in peat (Zoltai, 1988); and lake sediments (Jackson, 1978; 
Jackson et al., 1993). There are few comprehensive detailed studies, however, on the physical and chemical characteristics of heavy metals derived from industrial contamination and on their potential availability to biota. In this study, the forms of $\mathrm{Zn}, \mathrm{Hg}$, and $\mathrm{Ni}$ will be examined in humus and till collected at varying distances from the base metal smelting complex operated by Hudson Bay Mining and Smelting Corporation at Flin Flon, Manitoba $\left(55^{\circ} \mathrm{N}, 102^{\circ} \mathrm{W}\right)$, as a basis for assessing metal mobility and outlining criteria for the recognition of smelter-related contamination in the terrestrial environment.

The study area (Fig. 5.1) is ideally suited for examining the distribution of smelter contamination because it has been subjected to atmospheric deposition of particulate emissions for nearly 60 years and is remote from any significant industrial center. In addition, a comprehensive geochemical database for humus and till is available for the region as a result of a surficial geological mapping and geochemical prospecting project conducted in the Flin Flon-Snow Lake area, northern Manitoba and Saskatchewan $\left(99^{\circ} \mathrm{W}\right.$ to $103^{\circ} \mathrm{W}$ longitude; $54^{\circ} \mathrm{N}$ to $55^{\circ} 15^{\prime} \mathrm{N}$ latitude) by the Geological Survey of Canada and Manitoba Department of Energy and Mines (Fig. 5.1) (Henderson, 1995a; McMartin et al., 1996; McMartin et al., 1999). Humus and the underlying sediment, predominantly till, were sampled at more than 2000 sites over $36,000 \mathrm{~km}^{2}$ and analysed geochemically for a suite of major and trace elements. This database provides the context to assess the effects of prolonged smelter emission contamination in the terrestrial environment, in an area where the natural geological variation in heavy metal concentrations is well known. 


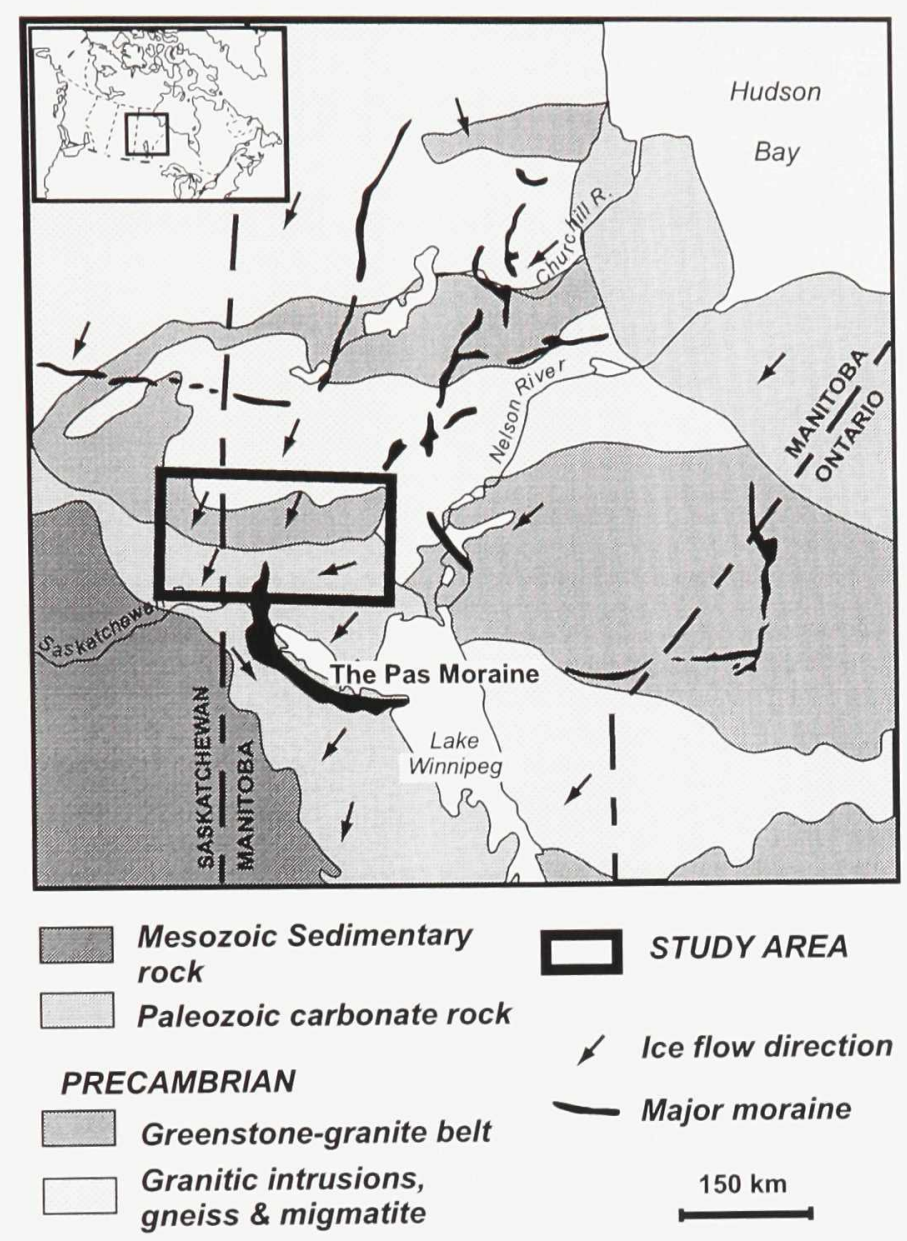

Figure 5.1 Location map of the regional study area showing generalized bedrock geology, major glacial landforms and ice flow directions. 
To characterize dispersal from the smelter, humus and till samples collected at varying distances from the stack, as well as from several soil profiles, were subjected to chemical partitioning through the application of sequential extraction techniques. In addition, the mineral composition of the non-organic portion of both humus and till was determined by x-ray analyses, and the size, composition and morphology of metal bearing particulates were characterized with a scanning electron microscope (SEM).

\subsection{Regional setting}

The area is situated at the margin of the Precambrian Shield (Figs. 5.1 and 5.2). It is underlain by rocks of four distinct geological terranes (Ashton, 1987; Syme et al., 1993; Stern and Lucas, 1995). Slightly metamorphosed volcanic and sedimentary rocks and associated intrusions of the Flin Flon-Snow Lake greenstone belt outcrop in the central part of the area. The Attitti Block, which forms the northwestern extension of this belt, is composed of the highly metamorphosed equivalent of greenstone belt lithologies (Ashton et al., 1995). In the north, the area is underlain by rocks of the Kisseynew Domain which consist of gneisses and associated intrusions. To the west, the greenstone belt is in tectonic contact with a geologically complex association of generally highly metamorphosed supracrustal and plutonic rocks that range widely in composition, the Hanson Lake Block. Unmetamorphosed Paleozoic dolostones and minor sandstones unconformably overlie the Precambrian rocks in the southern half of the area. 


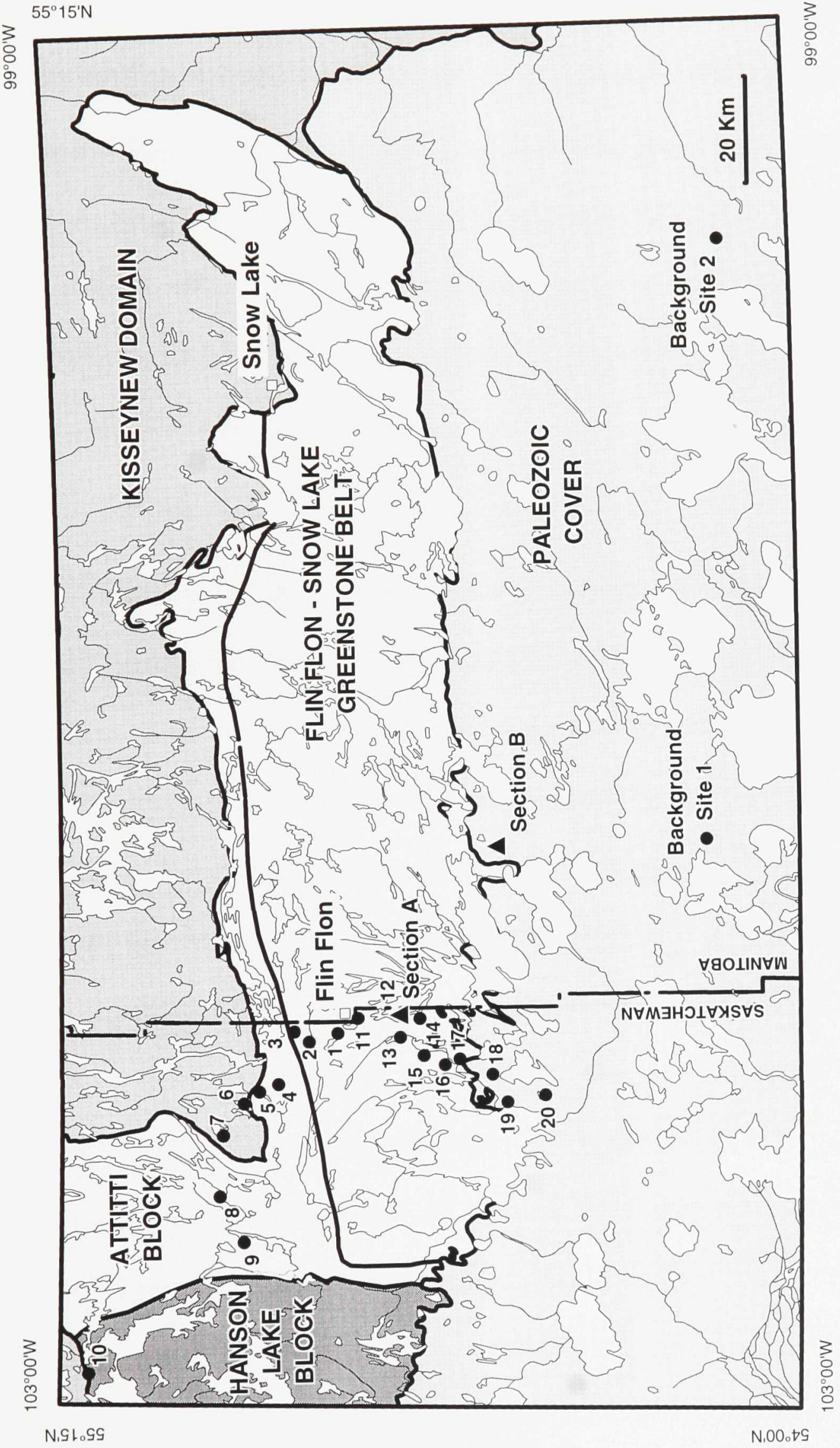

हే

0
0
0
0
0
0
0
0
0
0
0
0
0
0
0
0
0
0
0

$\stackrel{0}{\infty}$

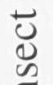

త్త

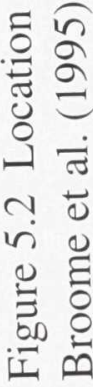


The area has a high potential for gold and base metal mineralization, particularly within the Flin Flon-Snow Lake greenstone belt. Gold occurs in sulphide-bearing fracture zones that may or may not be quartz-filled. Base metal deposits are essentially of two types: volcanic massive sulphide (VMS) deposits of $\mathrm{Cu}$ - Zn, and porphyry-style $\mathrm{Cu}$ mineralization in a volcanic vent setting. In the Flin Flon area, mines have been developed in large $\mathrm{Zn}$ deposits and smaller $\mathrm{Cu}$ or $\mathrm{Cu}-\mathrm{Zn}$ deposits. Extensive $\mathrm{Cu}$ and $\mathrm{Zn}$ mineralization has also been exploited in the Snow Lake area.

The area has been glaciated by ice flowing from two dispersal centers: one located in the District of Keewatin, the other located within the Labrador Sector of the Laurentide Ice Sheet (Dyke and Prest, 1987b). The dominant ice flow indicators in the northern and western part of the area indicate flow to the south-southwest from the Keewatin dispersal centre (Fig. 5.1). In the southeastern part of the study area, ice flowed west-southwestward from the Labradorean dispersal centre. Tills deposited by these glaciers primarily reflect local bedrock composition (Henderson, 1995a; McMartin et al., 1996). During ice retreat, the entire area was inundated by proglacial Lake Agassiz (Schreiner, 1984b; Teller and Clayton, 1983). As a result, deposits of glaciolacustrine clay occur in topographic depressions of the Shield and as thick blankets, overlain by peat, in Paleozoic terrane. The area is forested by a mixed coniferous deciduous boreal community comprising jack pine, black spruce, white spruce, trembling aspen, balsam poplar and speckled alder (Hogan and Wotton, 1984). At Flin Flon, the dominant winds are southeastward and southwestward, with strong north-northwestward and southward components (Environment Canada, 1993). 


\subsection{Smelter history and nature of emissions}

The base metal mining and smelting complex at Flin Flon produces $\mathrm{Zn}, \mathrm{Cu}$ and $\mathrm{Cd}$ metals on site, in addition to $\mathrm{Pb}$ concentrates and $\mathrm{Au}, \mathrm{Ag}, \mathrm{Se}$, and $\mathrm{Te}$ by-products which are recovered and refined off-site (Franzin et al., 1979). Since the early 30's, the complex has processed ore from local mines, undergoing many changes during that time to improve processing and comply with environmental standards. As a result, particulate stack emissions have decreased from an average of 13.983 tons/day in 1985 to 0.914 tons/day in 1995 (Hudson Bay Mining and Smelting Company, 1995). Nevertheless, the cumulative effects of emissions up to several kilometers from the smelter has resulted in high tree mortality, reduced growth, reduction in species diversity and soil erosion (Hogan and Wotton, 1984).

Presently, the majority (90\%) of stack dust escapes from the smelter baghouse (Salomon de Friedberg, 1993), however, prior to recent modifications, emissions were derived equally from the $\mathrm{Zn}$ precipitator $(48 \%)$ and smelter baghouse $(48 \%)$ (R. Tardiff, HBMS, per. com.). Chemical analyses of these smelter dusts indicate high concentrations of $\mathrm{Zn}, \mathrm{Fe}, \mathrm{Cu}, \mathrm{Pb}, \mathrm{Cd}$, and $\mathrm{As}$, with low to trace amounts of $\mathrm{Hg}, \mathrm{Cr}, \mathrm{Co}, \mathrm{Ni}$, and $\mathrm{Mn}$ (Hudson Bay Mining and Smelting Company, 1995). Analyses of archived dusts from the smelter baghouse and $\mathrm{Cu}$ and $\mathrm{Zn}$ precipitators indicate that retained particles are predominantly in the fine to medium silt size range $(0.002-0.031 \mathrm{~mm})$. These dusts vary in composition, but consist largely of angular and sperical particles of $\mathrm{Cu}, \mathrm{Zn}, \mathrm{Fe}$ sulphates and, to a lesser 
extent, oxides and sulphides commonly containing trace amounts of $\mathrm{Pb}$, As and/or $\mathrm{Cd}$. These results differ from those of Chen and Pint (1980) who report that more than 97 percent of the dust from the smelter baghouse contains $<0.001 \mathrm{~mm}$ sized grains of $\mathrm{ZnO}$, and possibly hydrous $(\mathrm{Zn}, \mathrm{Pb}, \mathrm{Fe}, \mathrm{Cu})$ sulphates/arsenates. The remaining 2-3 percent consists of 0.001$0.02 \mathrm{~mm}$ spherules of $\mathrm{Cu}$ metal (frequently with a $\mathrm{Cu}_{2} \mathrm{~S}$ rim), sulphides containing $\mathrm{Cu}, \mathrm{Fe}$ and/or $\mathrm{Zn}$, silicates (for example: (Fe), (Fe, Zn, Cu), (Fe, Zn, Cu, Ca), (Fe, Zn, Pb, Al, K) and $(\mathrm{Fe}, \mathrm{Zn}, \mathrm{Cu}, \mathrm{Al}, \mathrm{K})$ ), and oxides of $\mathrm{Zn}, \mathrm{Fe}, \mathrm{Cu}$, and/or $\mathrm{Pb}$, in addition to angular grains of $\mathrm{SiO}_{2}, \mathrm{CuFeS}_{2}, \mathrm{Cu}_{5} \mathrm{FeS}_{4},(\mathrm{Zn}, \mathrm{Fe}) \mathrm{S}, \mathrm{PbS}$, and silicates of varying composition (for example: ( $\mathrm{Zn}, \mathrm{Al}, \mathrm{Ca}),(\mathrm{Fe}, \mathrm{Zn}, \mathrm{Cu}),(\mathrm{Ca}, \mathrm{Al})$, and (Fe, Zn, Ca, Mg))(Chen and Pint, 1980).

\subsection{Previous work}

The regional distribution and deposition of smelter emissions in the surface terrestrial environment near Flin Flon has been examined using differing sampling media. By analysing rain and snow collected over several seasons, Franzin et al. (1979) showed that the smelter at Flin Flon is a source of airborne $\mathrm{Zn}, \mathrm{Cd}, \mathrm{Pb}, \mathrm{As}$, and $\mathrm{Cu}$. Zoltai (1988) showed that peat collected in bogs and fens was enriched in these smelter-related elements up to 100 $\mathrm{km}$ SSE from the smelter. Both studies concluded that the maximum radius of deposition varied depending on the element. Franzin et al. (1979) calculated distances of contamination ranging from 33 to $217 \mathrm{~km}$, such that the radius of $\mathrm{Zn}>\mathrm{Pb}>\mathrm{As}>\mathrm{Cu}$, while Zoltai (1988) concluded that the radius of $\mathrm{Cu}=\mathrm{As}>\mathrm{Zn}>\mathrm{Pb}$. Henderson and McMartin (1995) showed that $\mathrm{Hg}$ enrichment in humus was related to smelter emissions and extended over $40 \mathrm{~km}$ from the 
stack. Hogan and Wotton (1984) also found elevated values of $\mathrm{Cu}, \mathrm{Pb}$ and $\mathrm{Zn}$ in the upper organic layers of material on the forest floor (LFH layer) more than $40 \mathrm{~km}$ south and southeast from the smelter stack with $50-60 \% \mathrm{Zn}$ and $20-35 \% \mathrm{Cu}$ retained in a bio-available form.

The regional geochemical data and geochemical maps for humus and till collected in the Flin Flon-Snow Lake area (Fig. 5.2) have been published in Henderson (1995a) and McMartin et al. (1996). Geochemical maps for humus exhibit a "bull's eye" pattern, centered on the Flin Flon smelter, for $\mathrm{As}, \mathrm{Cd}, \mathrm{Cu}, \mathrm{Hg}, \mathrm{Pb}$, and $\mathrm{Zn}$. For these elements, concentrations are anomalously high at the center of the area, and decrease with distance from the smelter, such that the log-concentration of the heavy metal decreases directly with the log-distance from the smelter until regional background concentrations are reached (McMartin et al., 1999). Estimates of regional background determined statistically as the median value after the elimination of most contaminated samples (Table 5.1; Column C) indicate that distance-to-background ranges from 70 to $104 \mathrm{~km}$, with the radius of $\mathrm{As}>\mathrm{Cu}>\mathrm{Hg}>\mathrm{Zn}>\mathrm{Pb}>\mathrm{Cd}$. These results are similar to those of Zoltai (1988) and represent the maximum distance for recognition of smelter-related contamination, associated with each element, assuming an annular distribution pattern. It is evident from the geochemical maps, however, that the radius of recognizable contamination in humus varies with direction, extending further in the southeast, southwest, and northwest, consistent with the prevailing winds in the area (McMartin et al., 1999). These maps also show that concentrations of trace elements less evident in smelter emissions $(\mathrm{Ni}, \mathrm{Co}, \mathrm{Cr}$ ) were generally lower in humus than 


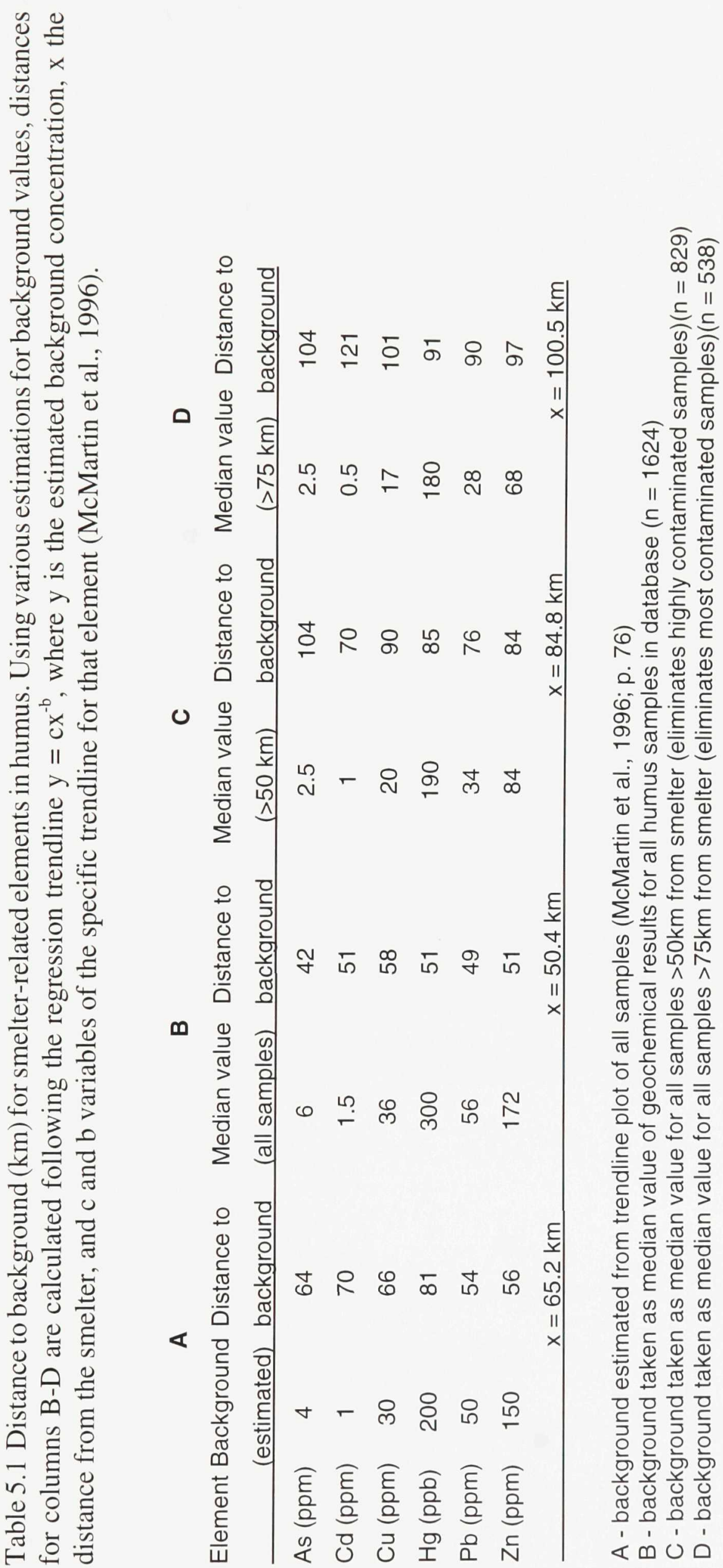


till and that the distribution in humus did not form a "bull's eye" pattern.

In the clay-sized fraction $(<0.002 \mathrm{~mm})$ of till, concentrations of all smelter-related elements were commonly lower than in humus with the distribution pattern relating primarily to bedrock composition modified by the effects of glacial erosion, transport, and deposition (Henderson, 1995a; McMartin et al., 1996; McMartin et al., 1999).

\subsection{Methods}

\subsubsection{Field procedures}

Based on distance from the smelter and stratigraphic context, humus and till samples from 23 sites in the regional geochemical survey were selected for detailed mineralogical, geochemical and physical analyses. On a regional basis, 3-kg till samples were collected from below the B soil horizon either from exposed sections or pits hand dug to bedrock or $1 \mathrm{~m}$ maximum depth. In addition, two excavated till exposures were sampled vertically at 10 to $50 \mathrm{~cm}$ intervals.

Approximately 50 - $100 \mathrm{~g}$ humus was collected from directly over or adjacent to the till sample (Henderson, 1995a; McMartin et al., 1996). The well decomposed, dark organic part of the soil horizon $(\mathrm{H})$ was preferentially sampled for humus (Agriculture Canada, 1987). At some sites, however, partially decomposed forest litter and mineral soil (Ah) may 
constitute part of the sample, since organic soil horizons in the region are generally thin (5-7 $\mathrm{cm})$. In this paper, the term "humus" will be used to represent all samples from the upper organic rich part of the soil horizon, although those containing $<30 \%$ organic matter cannot strictly be regarded as humus (Agriculture Canada, 1987).

5.5.2 Analytical procedures

\subsubsection{Sample preparation}

Humus samples were air-dried and sieved to $<0.425 \mathrm{~mm}$; the clay-sized fraction $(<0.002 \mathrm{~mm})$ of till was separated by centrifugation and decantation (Lindsay and Shilts 1995). In addition, the silt and clay-sized fraction $(<0.063 \mathrm{~mm})$ of till for some samples was separated by dry sieving (Henderson, 1995a).

\subsubsection{Standard Geochemical Analyses}

All size fractions were analysed geochemically for $\mathrm{Ag}, \mathrm{Al}, \mathrm{As}, \mathrm{Ba}, \mathrm{Bi}, \mathrm{Ca}, \mathrm{Cd}, \mathrm{Co}$, $\mathrm{Cr}, \mathrm{Cu}, \mathrm{Fe}, \mathrm{Hg}, \mathrm{K}, \mathrm{La}, \mathrm{Mg}, \mathrm{Mn}, \mathrm{Mo}, \mathrm{Na}, \mathrm{Ni}, \mathrm{P}, \mathrm{Pb}, \mathrm{Sb}, \mathrm{Sc}, \mathrm{Sr}, \mathrm{Ti}, \mathrm{V}$, and $\mathrm{Zn}$ using inductively-coupled plasma atomic emission spectrometry (ICP-AES), following nitric-aqua regia digestion. Mercury in humus $(<0.425 \mathrm{~mm})$ and the clay-size fraction $(<0.002 \mathrm{~mm})$ of till was analysed by cold vapour atomic absorption spectrometry (CV-AAS) following aqua regia digestion. Analyses of duplicate samples and laboratory standards were used to monitor analytical accuracy and precision (Henderson, 1995a; McMartin et al., 1996). 


\subsubsection{Loss-on-ignition (percent LOI)}

The total organic content of humus $(<0.425 \mathrm{~mm})$ was determined by heating a small portion of the oven dried sample to approximately $550^{\circ} \mathrm{C}$ for one hour. The resulting weight loss, expressed as a percentage of the dry weight, provides an estimate of the amount of organic matter in the sample (Sheldrick, 1984). A correlation $(r=0.52)$ exists between percent LOI and total soluble organic content determined geochemically using the sodium pyrophosphate leach (see section below, Sequential Extraction Analyses).

\subsubsection{X-ray diffraction (XRD)}

The mineralogy of till $(<0.002 \mathrm{~mm})$ and the inorganic fraction of humus $(<0.425 \mathrm{~mm})$ was determined using a Philips PW1710 automated powder diffractometer equipped with a graphite monchromater, CoKa radiation at $40 \mathrm{kV}$ and $30 \mathrm{~mA}$. The samples were also $\mathrm{X}$-rayed following saturation with ethylene glycol and heat treatment $\left(550^{\circ} \mathrm{C}\right)$. To remove organic material from humus prior to analyses, samples were pre-treated with 30 percent hydrogen peroxide, washed with distilled water, and dried at room temperature (Sheldrick, 1984).

\subsubsection{Sequential Extraction Analyses}

The sequential extraction scheme used to analyse the $<0.425 \mathrm{~mm}$ fraction of humus and the $<0.002 \mathrm{~mm}$ fraction of till is summarized in Table 5.2. A detailed description of methodology and quality control is presented by Hall et al. (1996). Humus samples were 


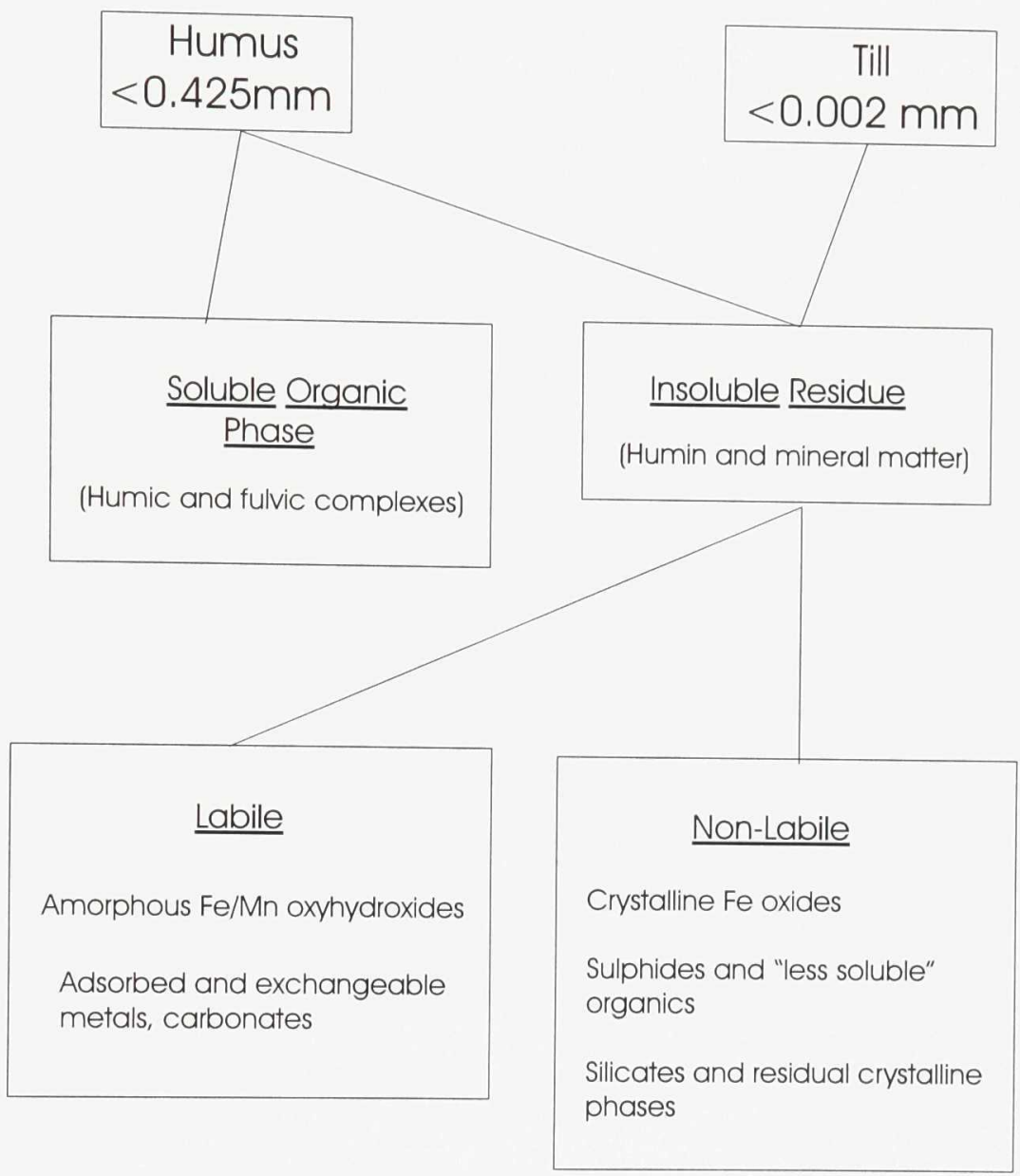

Table 5.2 Sequential extraction scheme (modified from Kaszycki and Hall, 1996). 
initially leached with sodium pyrophosphate $\left(\mathrm{Na}_{4} \mathrm{P}_{2} \mathrm{O}_{7}\right)$ to extract the "soluble organic" component (humic and fulvic complexes) prior to sequential extraction of the "insoluble residue" (humin and mineral matter). Solutions derived from the application of the leaches were analysed by flame atomic absorption spectrometry (AAS) for $\mathrm{Cd}, \mathrm{Co}, \mathrm{Cu}, \mathrm{Fe}, \mathrm{Mn}, \mathrm{Ni}$, $\mathrm{Pb}$, and $\mathrm{Zn} ; \mathrm{Hg}$ was analysed by vapour generation (ICP-MS); As by quartz tube AAS after hydride generation.

Sequential extraction has been used in exploration and environmental geochemistry to determine element residence sites (Chao, 1984). The technique differentiates between elements held in "labile" or secondary phases (soluble organic matter, adsorbed/exchangeable/carbonate (AEC), and amorphous Fe/Mn oxyhydroxide phases) from those more strongly held in "non-labile" phases (crystalline Fe oxide, sulphide/"less soluble" organic, and silicate/residual crystalline phases)(Table 5.2). Selectivity is not perfect and extraction efficiencies vary depending on the chemicals employed, the length of treatment, and sediment-to-extractant ratio (Hall et al., 1996).

\subsubsection{Scanning Electron Microscope (SEM)}

Humus ( $<0.425 \mathrm{~mm}$ fraction) and till $(<0.002 \mathrm{~mm}$ and $<0.063 \mathrm{~mm}$ fraction $)$ samples were examined under the scanning electron microscope (SEM) using grain mounts prepared by sprinkling sample material onto a carbon impregnated tape. Grain mounts were carboncoated prior to examination. A Leica Cambridge Stereoscan S360 SEM equipped with an 
Oxford/Link eXL-II energy-dispersion X-ray analyzer, Oxford/Link Pentafet Be window/light element detector, and an Oxford/Link Tetra backscattered electron detector was used. Samples were scanned using the backscattered electron imaging mode specifically to identify grains with elements of high atomic number.

\subsection{Results}

The samples selected for detailed chemical, mineralogical and physical analyses are from 23 sites in the regional geochemical survey. These sites are located at varying distances from the smelter and represent two transects extending from the point source, and two "background" locations (Fig. 5.2). The first transect (Sites 1-10) extends $82 \mathrm{~km} \mathrm{NNW} \mathrm{from}$ the smelter across metasedimentary and metavolcanic rocks of the Flin Flon greenstone belt (Sites 1 - 3), the Attitti Block of the Flin Flon terrane (Sites 4, 5, 8, and 9), gneisses and associated intrusive rocks of the Kisseynew Domain (Sites 6 and 7), and gneissic and supracrustal rocks of the Hanson Lake Block (Site 10). The second transect (Sites 11-20) extends $40 \mathrm{~km} \mathrm{SSW}$ from the smelter. Sites 11-17 are underlain by rocks of the Flin Flon greenstone belt and Sites 18-20 by Paleozoic carbonate rocks.

The two background sites overlie Paleozoic bedrock (Fig. 5.2). Site 1 is located 74.8 $\mathrm{km}$ SSE from the smelter. At this site, humus overlies glaciolacustine clay and a locally derived, moderately calcareous till. Site 2 is located $160.4 \mathrm{~km}$ southeast of Flin Flon in an area of highly calcareous till. 
5.6.1 Mineralogy and organic content

Humus represents the organic-bearing mineral-rich surface horizon of the soil profile and includes varying amounts of material derived from the smelter through atmospheric deposition. The relative proportion and composition of the organic and mineral component will affect humus geochemistry since certain phases have a tendency to scavenge trace metals (Rose et al., 1979; Varskog et al., 1993). In this study, the total organic content (percent LOI) of humus ( $<0.425 \mathrm{~mm}$ fraction) varies from 22.72 to 92.15 percent (Table 5.3; Fig. 5.3). The inorganic component of the samples consists primarily of common rock-forming minerals (quartz, plagioclase, potassic feldspar), with trace amounts of amphibole, mica and chlorite, particularly at sites in the Flin Flon greenstone belt. Dolomite is abundant at sites overlying Paleozoic bedrock.

The clay-size fraction $(<0.002 \mathrm{~mm})$ of till comprises quartz, plagioclase, potassic feldspar, and abundant to moderate amounts of mica, chlorite, kaolinite, and smectite (possibly montmorillonite). Locally, trace to moderate amounts of amphibole occur in samples overlying greenstone belt rocks. As with humus, dolomite and calcite are present in tills overlying Paleozoic terrane.

\subsubsection{Geochemical composition}

All transect sites and Background Site 1 lie within the zone of recognizable smelter contamination in humus for smelter-related elements defined by the regional database, except 


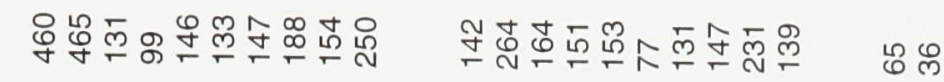

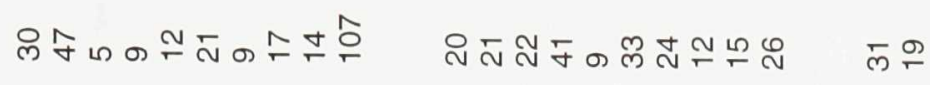

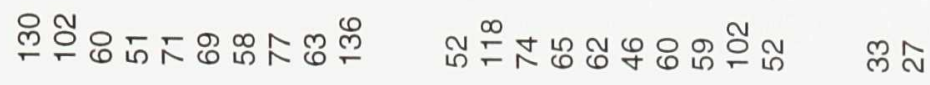

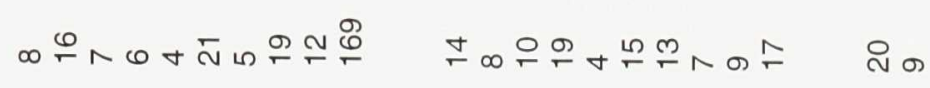

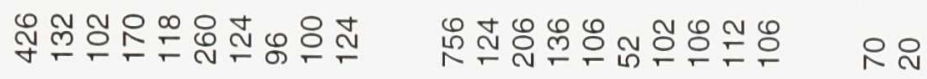

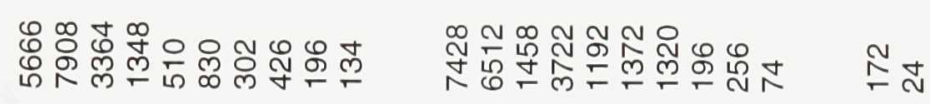

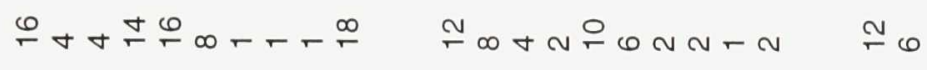

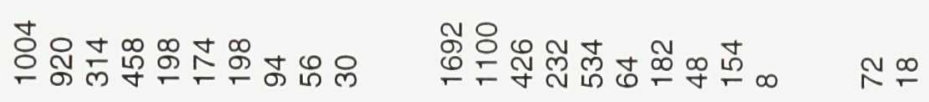

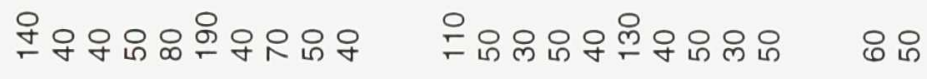

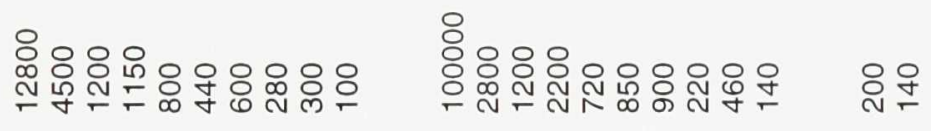

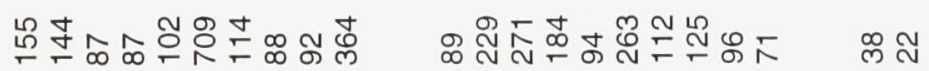

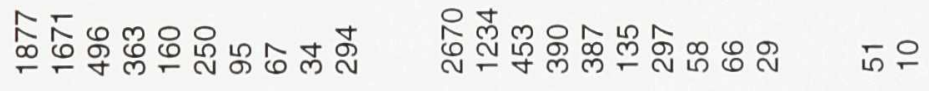

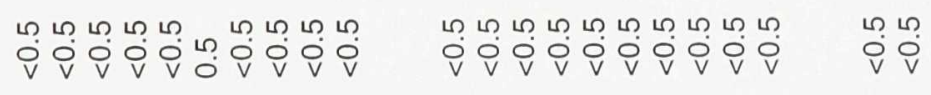

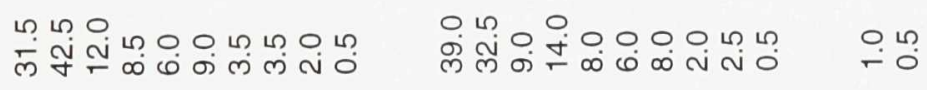

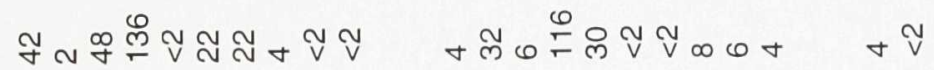

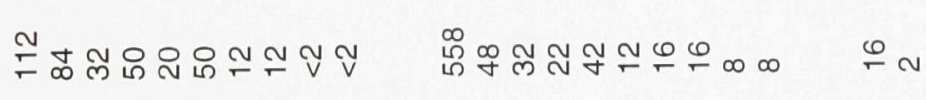

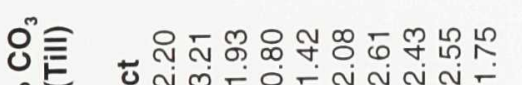

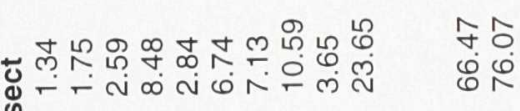

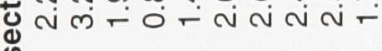

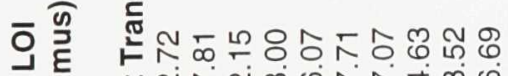

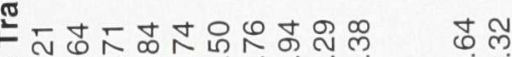

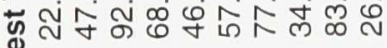

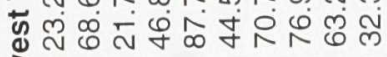

ङं क्र 
NNW TRANSECT
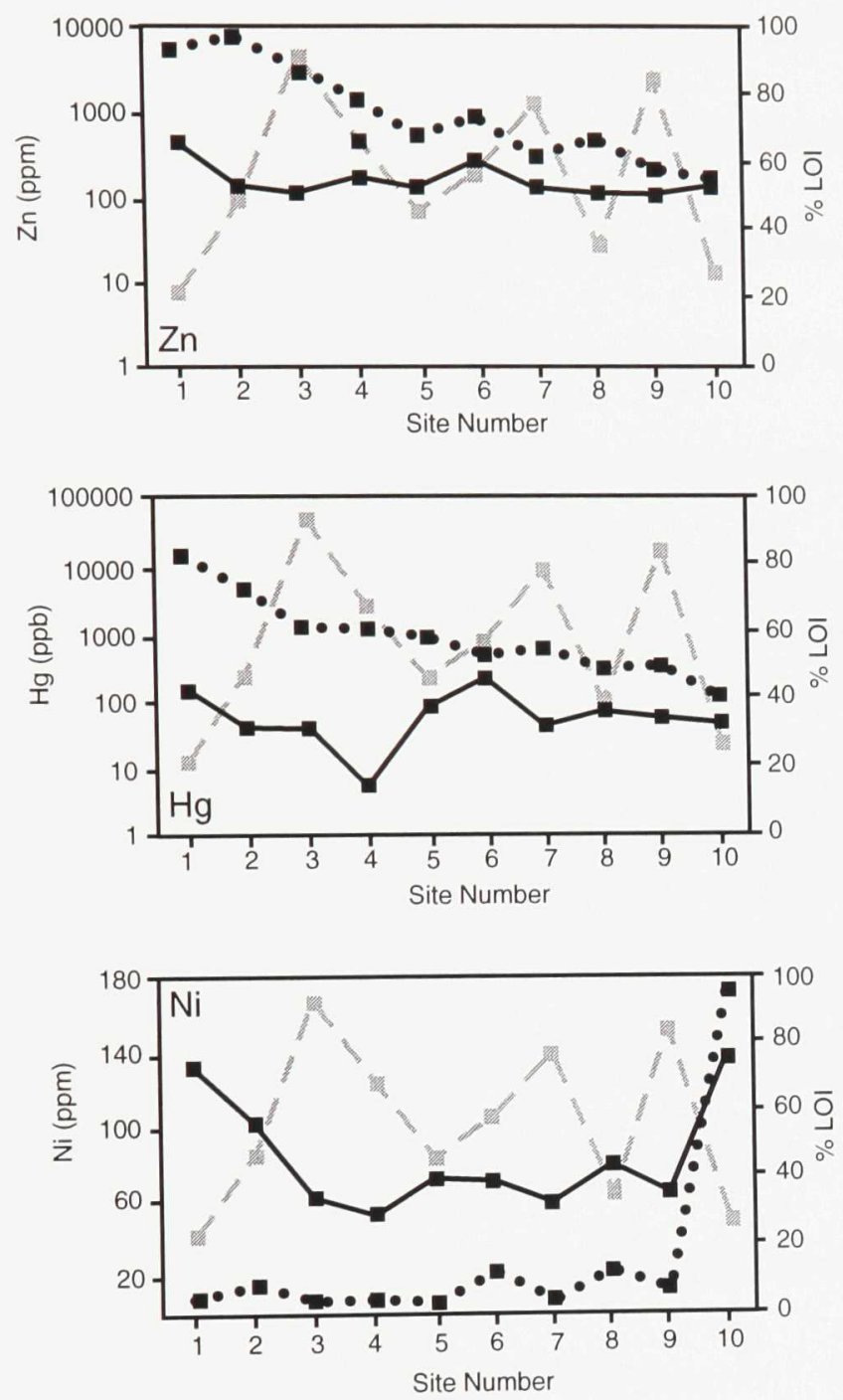

SSW TRANSECT
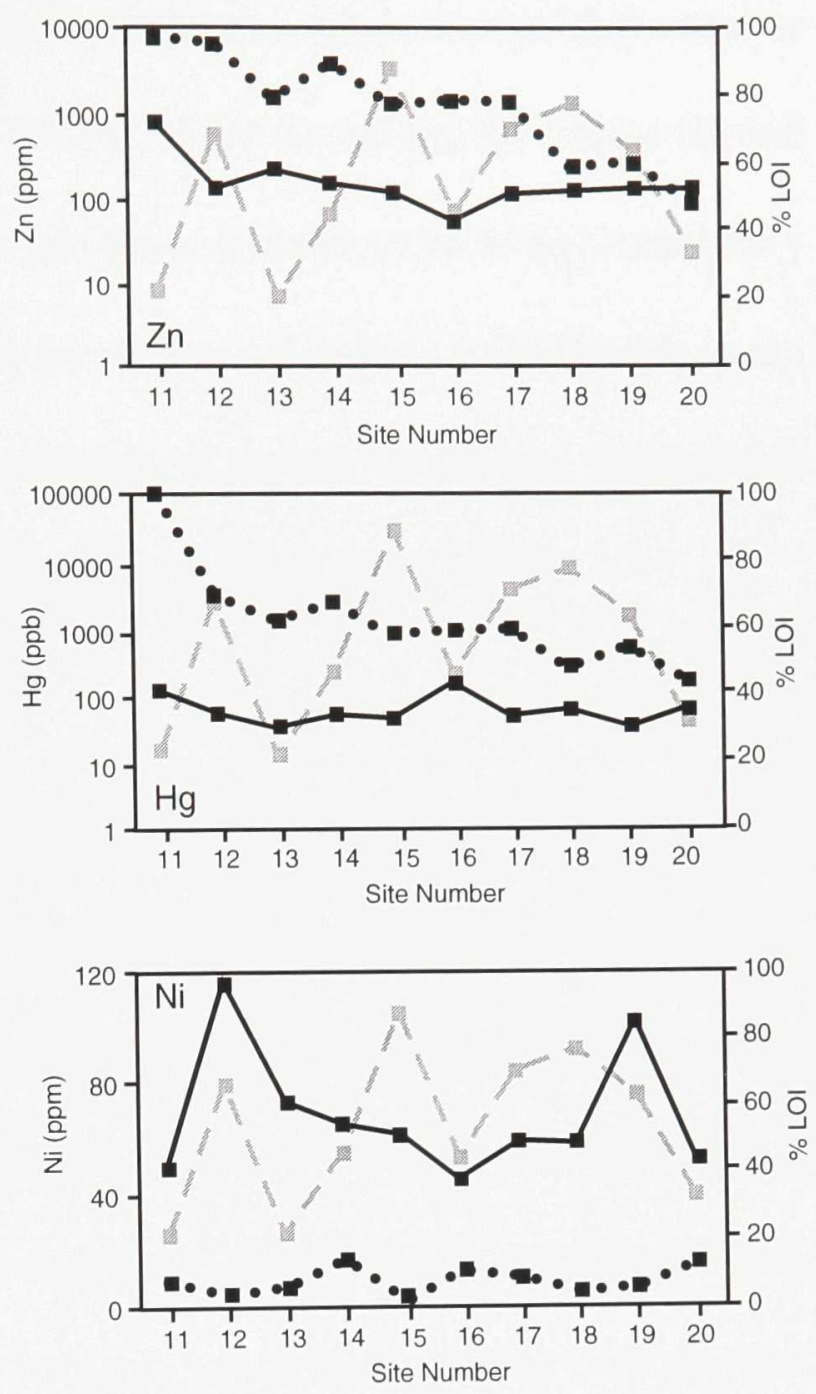

Figure 5.3 Total organic content (percent LOI) of humus and total concentrations of $\mathrm{Zn}, \mathrm{Hg}$ and $\mathrm{Ni}$ in humus and till collected from transect sites. Transects extend $82 \mathrm{~km} \mathrm{NNW}$ and $40 \mathrm{~km}$ SSW from the smelter at Flin Flon. 
for $\mathrm{Cd}$ and $\mathrm{Pb}$ (Table 5.3)(cf. Table 5.1; Column C). In humus, total concentrations near or less than background values occur at Site 9 for As, Site 10 for As and $\mathrm{Hg}$, Site 20 for $\mathrm{Hg}$ and Zn, and Background Site 1 for Hg. On a site-to-site basis, differences between actual heavy metal concentrations and those predicted from the regional distribution (McMartin et al., 1999) are to be expected given the complex interplay of factors controlling atmospheric deposition of smelter emissions and humus geochemistry (Rose et al., 1979).

In humus, total concentrations of all smelter-related elements decrease with distance from the smelter (Table 5.3) and, as illustrated by the distribution of $\mathrm{Zn}$ and $\mathrm{Hg}$ (Fig. 5.3), are independent of total organic content (percent LOI) $(\mathrm{Zn}, \mathrm{r}=0.23 ; \mathrm{Hg}, \mathrm{r}=0.33)$. In the case of $\mathrm{Zn}$, samples collected within $5 \mathrm{~km}$ from the smelter are enriched to a maximum of 94 times the regional background value, at $10 \mathrm{~km}$ approximately 40 times, at $20 \mathrm{~km} 16$ times, at $40 \mathrm{~km} 5$ times, and at $80 \mathrm{~km}$ only 1.6 times regional background. Mercury, on the other hand, is enriched in humus as much as 500 times the regional background value at sites $<5$ $\mathrm{km}$ from the smelter and drops to approximately 6 times at $10 \mathrm{~km} ; 4$ times at $20 \mathrm{~km}$; and 1.5 times at a distance of $40 \mathrm{~km}$ from the smelter (Table 5.3)(cf. Table 5.1; Column C). In general, concentrations of all smelter-related elements in humus exceed those in till, although exceptions are present for $\mathrm{As}, \mathrm{Cu}$, and $\mathrm{Zn}$ at several sites (Table 3). Concentrations of trace elements unrelated to smelter emissions ( $\mathrm{Ni}, \mathrm{Cr}$ ) are consistently lower in humus than till, with the exception of Ni at Site 10 (Fig. 5.3). This site is located in the Hanson Lake Block and anomalous values in both humus and till may be associated with the presence of Ni-rich mafic dykes throughout the area (Ashton, 1989). 
In till, concentrations of smelter related elements show no direct relationship to distance from the smelter (Fig. 5.3). Values are less variable than in humus, fluctuating around regional background (McMartin et al., 1996).

\subsubsection{Chemical speciation}

Chemical partitioning in humus and till was achieved through selective, sequential extraction analyses. For the purposes of discussion, phases determined through the application of this technique, are grouped: for humus, into the soluble organic phase (humic and fulvic complexes), and the relatively labile and non-labile components of the insoluble humus residue (humin and mineral matter), and for till, the labile and non-labile phases (Table 5.2).

Partitioning effects differ depending on the element and the sample medium (Table 5.4). Based on the phase distribution of trace elements in humus in relation to organic content, three broad categories have been recognized:

1. Smelter related elements having a strong correlation between the proportion associated with the "soluble organic" phase and the total organic content (percent $\mathrm{LOI})(\mathrm{Zn}, \mathrm{Pb}, \mathrm{Cd}$ and $\mathrm{Cu}$ );

2. Smelter related elements having no such correlation (As, $\mathrm{Hg})$; and

3. Non-smelter related elements for which concentrations in humus are low for all phases $(\mathrm{Co}, \mathrm{Ni})$. 
Table 5.4 Relative distribution of heavy metals in various phases of humus and till.

\section{Humus}

Soluble Organic Phase (\% of total concentration)

Insoluble Residue
$\%$ Labile
(of insoluble residue)

$\begin{array}{ccc}\text { Element } & \text { Average } & \text { Max-Min. } \\ \mathrm{As} & 16 & 34-6 \\ \mathrm{Cd} & 45 & 73-7 \\ \mathrm{Cu} & 32 & 50-16 \\ \mathrm{Hg} & 18 & 40-5 \\ \mathrm{Ni} & 24 & 60-0 \\ \mathrm{~Pb} & 49 & 75-9 \\ \mathrm{Zn} & 54 & 78-9\end{array}$

$\begin{array}{cccr}\text { Average } & \text { Max-Min } & \text { Average } & \text { Max-Min. } \\ 43 & 68-23 & 57 & 77-32 \\ 63 & 89-14 & 37 & 86-11 \\ 50 & 68-30 & 50 & 68-32 \\ 2 & 4-<1 & 98 & 100-96 \\ 38 & 75-6 & 62 & 94-25 \\ 65 & 83-51 & 35 & 49-17 \\ 23 & 49-7 & 77 & 93-51\end{array}$

Till

$$
\text { \%Labile Insoluble Residue }
$$

\section{\%Labile}

\section{$\%$ Non-Labile}

$\begin{array}{ccc}\text { Element } & \text { Average } & \text { Max-Min. } \\ \mathrm{As} & 19 & 30-9 \\ \mathrm{Cd} & 64 & 88-5 \\ \mathrm{Cu} & 33 & 54-15 \\ \mathrm{Hg} & 14 & 27-5 \\ \mathrm{Ni} & 17 & 35-6 \\ \mathrm{~Pb} & 42 & 100-14 \\ \mathrm{Zn} & 31 & 75-18\end{array}$

$\begin{array}{cc}\text { Average } & \text { Max-Min } \\ 81 & 91-74 \\ 36 & 95-12 \\ 67 & 85-49 \\ 86 & 95-73 \\ 83 & 95-65 \\ 58 & 86-0 \\ 69 & 83-25\end{array}$


Sequential analytical results are discussed for three elements representative of each category ( $\mathrm{Zn}, \mathrm{Hg}, \mathrm{Ni}$ ): $\mathrm{Zn}$ and $\mathrm{Hg}$ are of environmental significance; whereas $\mathrm{Ni}$ is not characterized as an important trace metal emitted from the Flin Flon smelter (Table 5.5).

\subsubsection{Zn partitioning}

\section{$\underline{\text { Humus }}$}

$\mathrm{Zn}$ concentrations in all phases decrease generally with distance from the smelter (Fig. 5.4a). The highest percentage of $\mathrm{Zn}$ is associated with the soluble organic phase, for most sites (Table 5.5; Figure 5.4b), and a correlation is present between the percent $\mathrm{Zn}$ in that phase and percent LOI (Fig. 5.5a). A significant component of $\mathrm{Zn}$ in humus must also reside in the insoluble residue, however, because no correlation exists between total $\mathrm{Zn}$ concentrations and percent LOI (Fig. 5.5b).

In the insoluble humus residue, the ratio of $\mathrm{Zn}$ in labile to non-labile phases increases generally with distance from the smelter (Figure 5.4b). Close to the smelter, the relative proportion of $\mathrm{Zn}$ in the non-labile phases is high (Table 5.5), attaining $>90 \%$ at sites within $3 \mathrm{~km}$ from the smelter (Sites 1 and 11). This spatial distribution suggests that $\mathrm{Zn}$ concentrations near the smelter are strongly influenced by smelter-derived particulates, such as Zn-rich silicates and Fe oxides (Chen and Pint, 1980), which would be expressed geochemically in the residual crystalline and crystalline Fe oxide phases of the non-labile component of the insoluble humus residue. Definitive linkages between this component and smelter-derived particulates through geochemical analyses is difficult, however, especially 


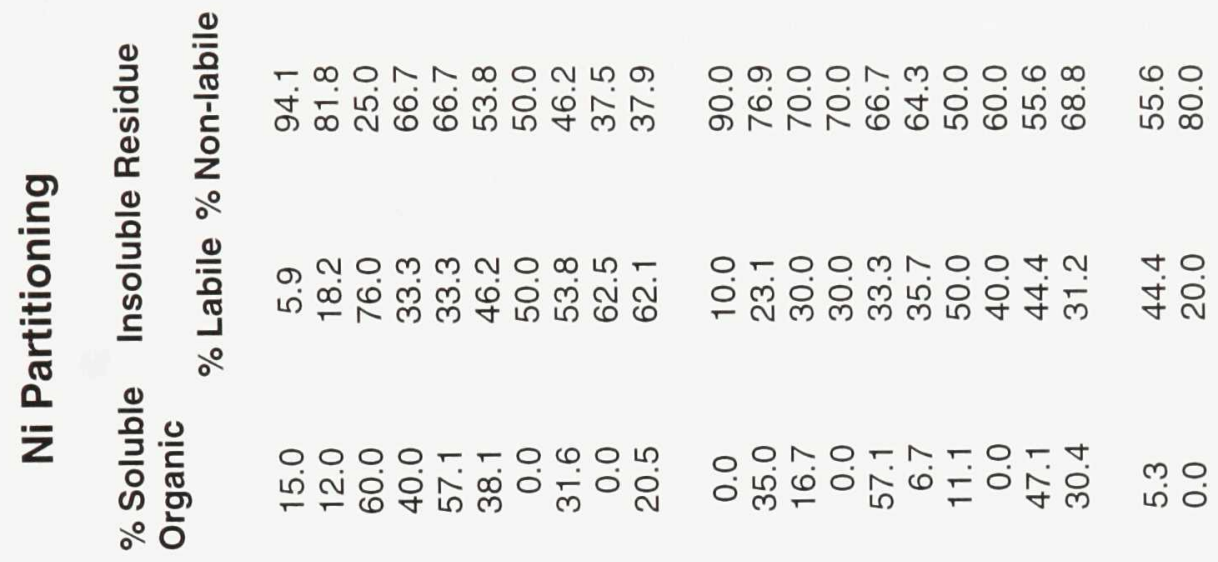

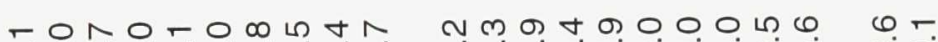

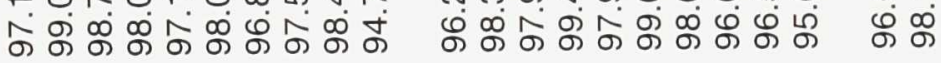

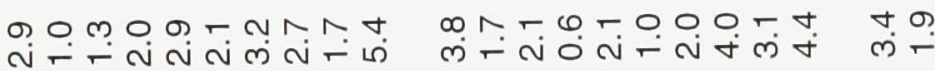

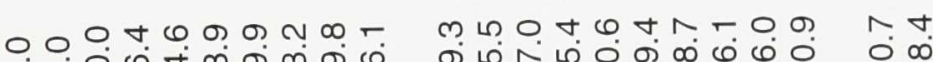

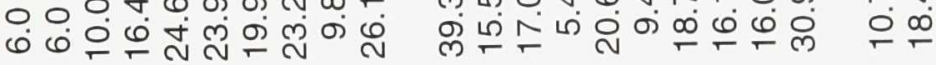

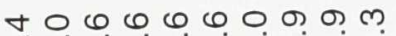

$\infty$ o 0 .

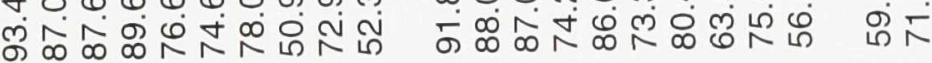

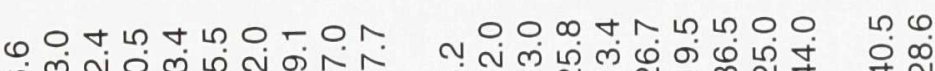

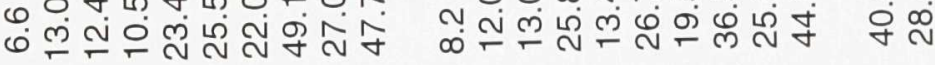

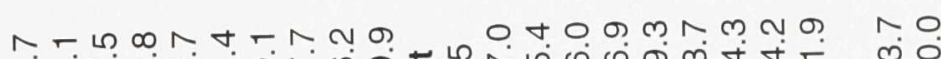

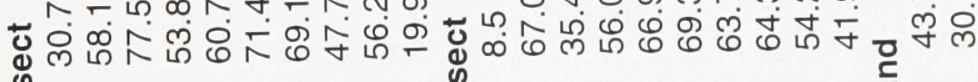




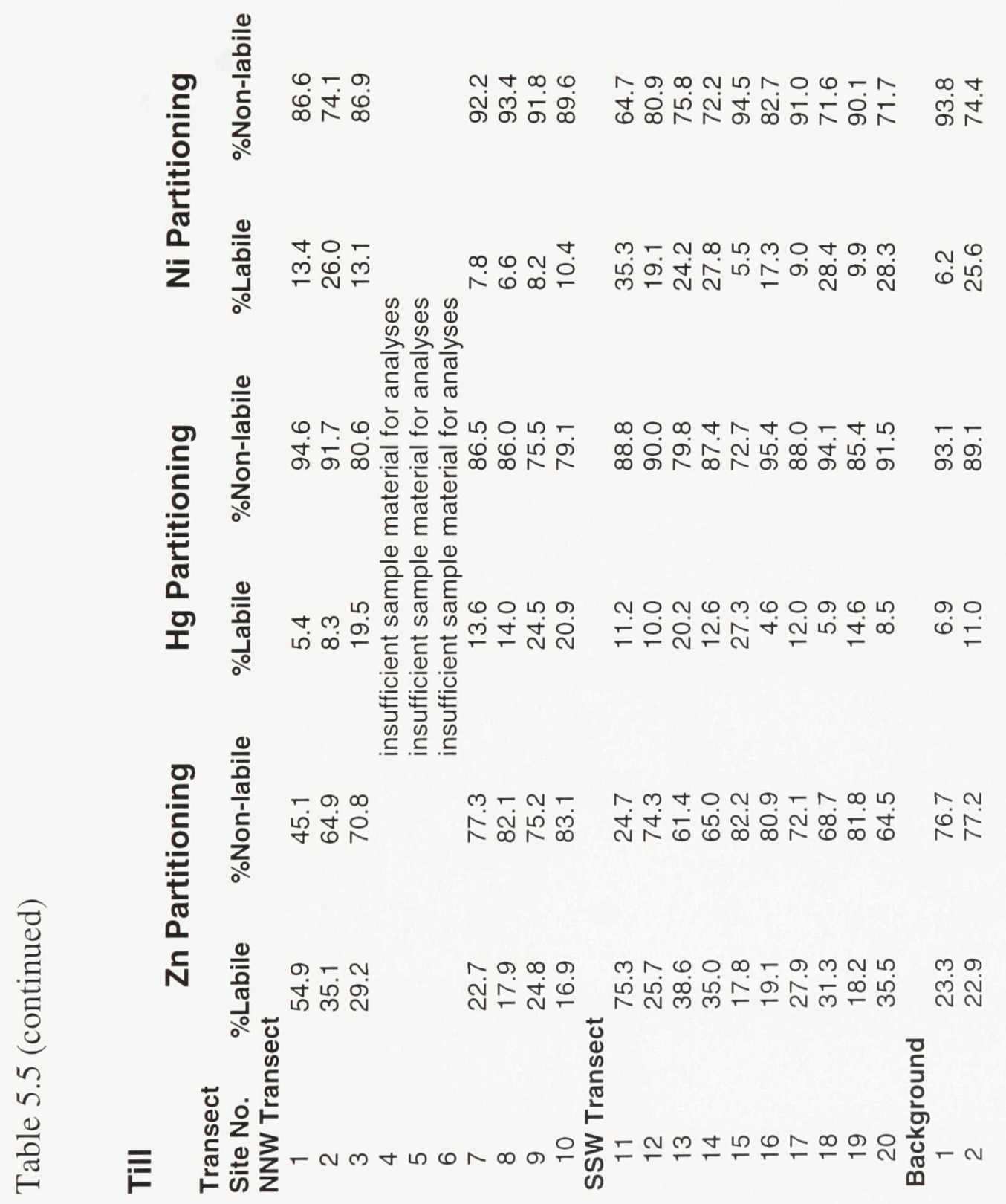




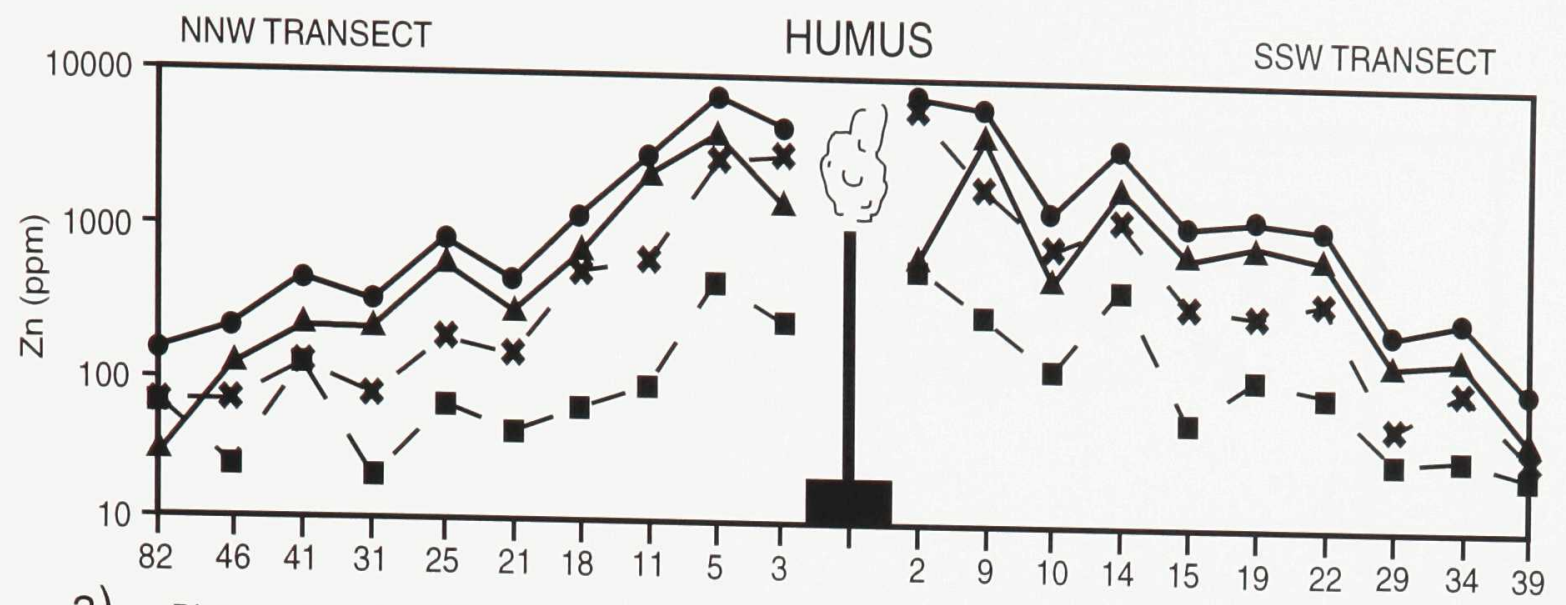

a) Distance from Smelter $(\mathrm{km})$
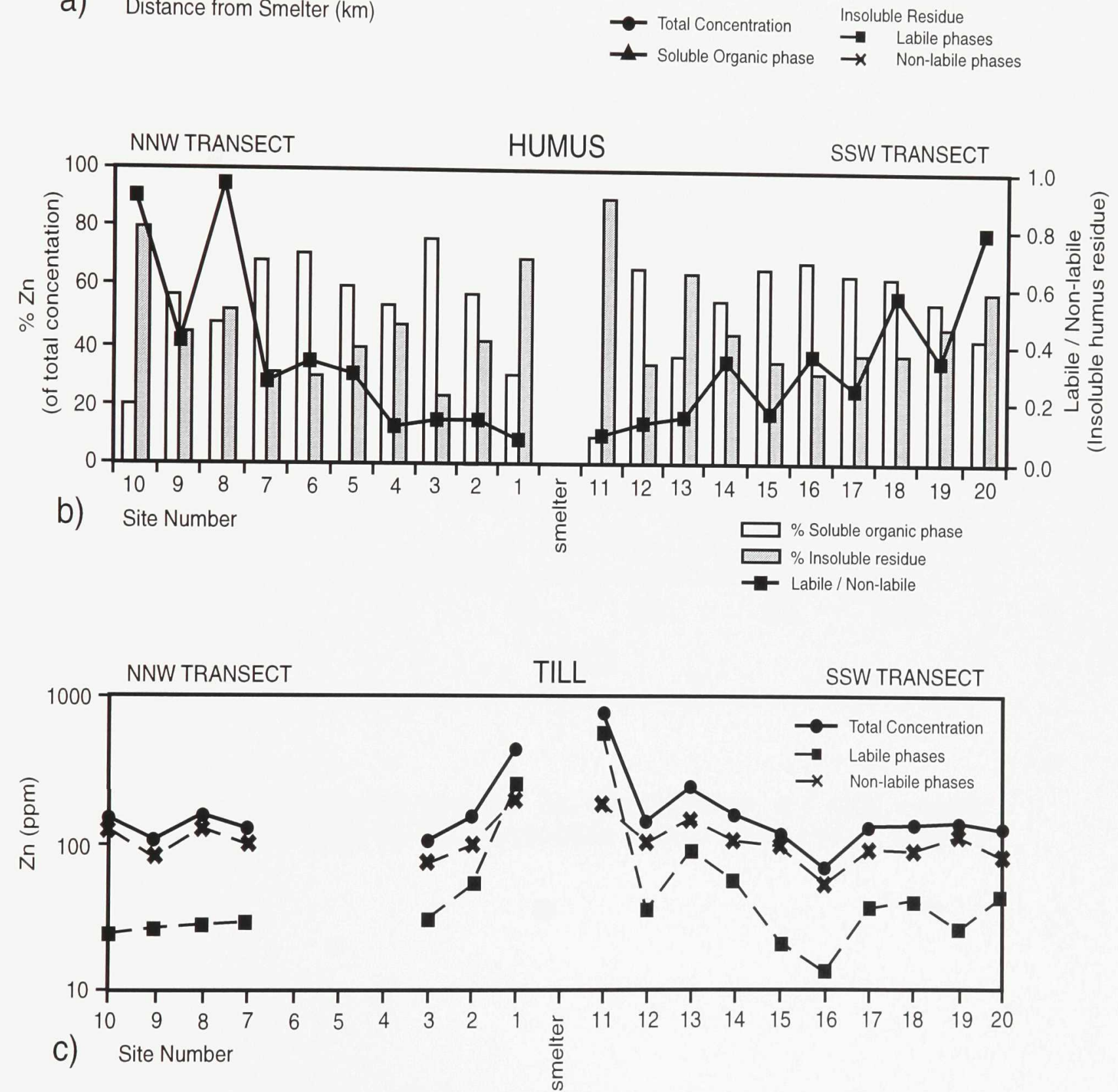

Figure 5.4 Partitioning of $\mathrm{Zn}$ in samples collected from transect sites: (a) total concentration in various phases of humus, (b) percent total $\mathrm{Zn}$ in soluble organic phase and insoluble humus residue and ratio between labile and non-labile component of insoluble humus residue, (c) total concentration in various phases of till. 

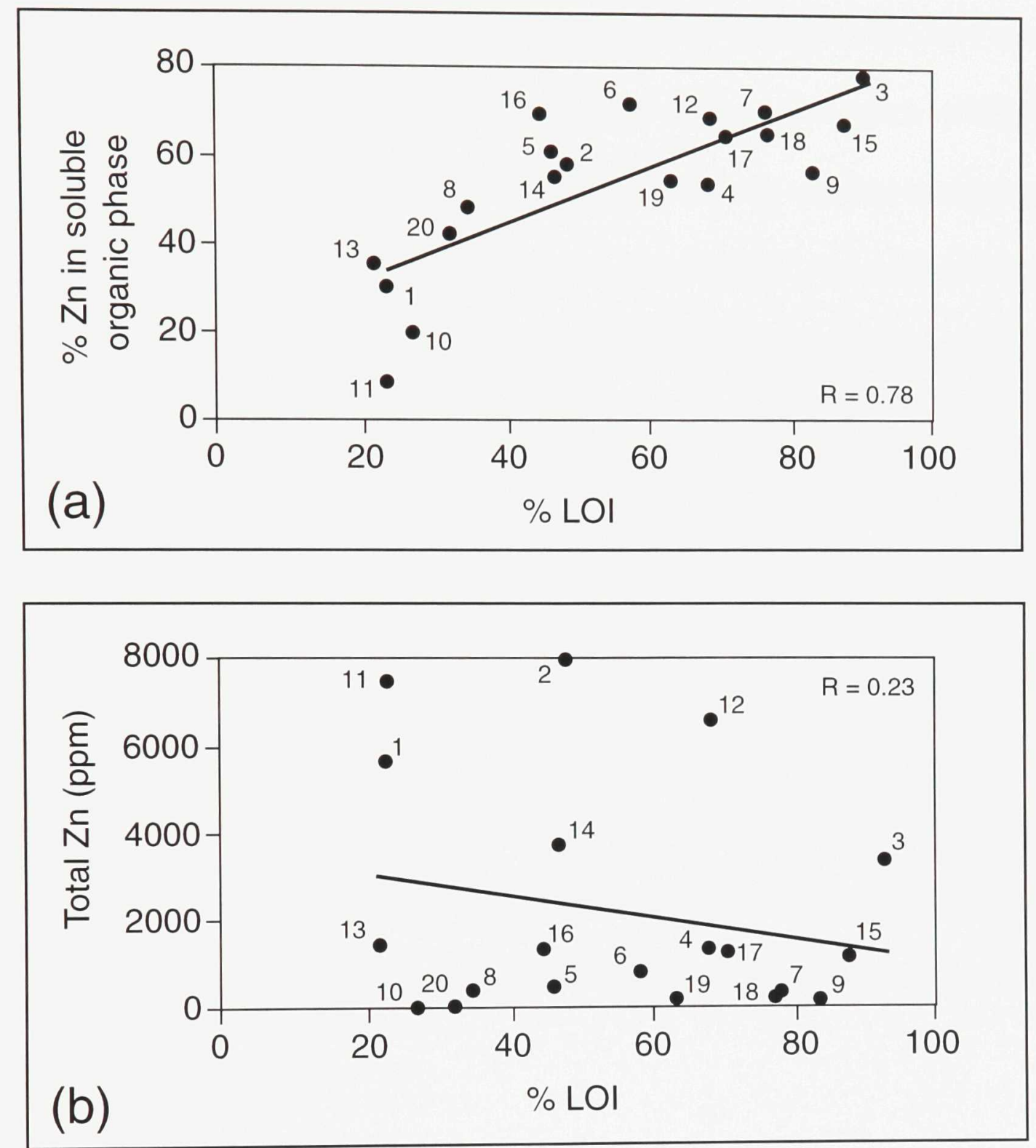

Figure 5.5 Relationship between $\mathrm{Zn}$ concentrations and total organic content (percent LOI): (a) $\% \mathrm{Zn}$ in soluble organic phase and (b) total $\mathrm{Zn}$ (ppm). 
at sites more removed from the smelter, since naturally occurring minerals also contain these trace elements. Chemical partitioning in humus from the Snow Lake area, $>120 \mathrm{~km}$ from the smelter (Fig. 5.2), where total Zn concentrations approximate regional background (Table 5.1), also shows a high proportion of Zn in non-labile phases (Kaszycki and Hall, 1996). There, partitioning in the insoluble humus residue is interpreted to reflect the mineralogy of underlying till.

The proportion of $\mathrm{Zn}$ in the labile component of the insoluble humus residue generally increases with distance from the smelter (Figure 5.4b; Table 5.5). The higher relative influence of these labile phases in partitioning indicates that $\mathrm{Zn}$ concentrations are increasingly affected by secondary chemical processes (such as weathering, alteration, etc.) at sites removed from the stack. These secondary processes may only be recognizable with distance from the smelter when the rate of chemical weathering exceeds the rate of clastic deposition from the smelter.

Low Zn concentrations (24 ppm; Table 5.3) at Background Site 2 are characteristic of humus overlying Paleozoic terrane (McMartin et al., 1996; McMartin et al., 1999). Geochemical differences among phases cannot be distinguished at these low concentrations, due to analytical imprecision near lower detection limits. 
$\underline{\text { Till }}$

Zn partitioning in till appears to be related, at least in part, to distance from the smelter (Fig. 5.4c). Near Flin Flon (Sites 1 and 11), total Zn concentrations are elevated compared to other transect samples, with $\mathrm{Zn}$ residing primarily in labile phases (Table 5.5). The $\mathrm{Zn}$ enrichment and its phase distribution may result from:

1. Geological Enrichment associated with the greenstone belt near Flin Flon. Sites along the SSW transect lie down-ice from $\mathrm{Zn}-\mathrm{Cu}$ mines, and $\mathrm{Zn}$ enrichment in labile phases may result from oxidation of sulphide minerals derived from mineralized zones.

2. Smelter Contamination. Sites near the smelter are characterized by poorly developed humus (LOI averages 23\%) with anomalously high Zn concentrations. Zn enrichment in labile phases of till may result from downward leaching because of the lack of a well developed organic horizon or, more directly because of the high level of contamination in humus at these sites. This possibility will be considered further by examining vertical sections through till.

The relative proportion of $\mathrm{Zn}$ in labile phases of till is also higher than average at other sites close to the smelter (2,3,13, and 14), and in carbonate-rich tills (18 and 20) near the southern end of the transects. Since an average of $69 \% \mathrm{Zn}$ in humus is retained in easily leached forms at distances $>3 \mathrm{~km}$ from the smelter, the phase distribution at these sites may also result, at least in part, from leaching from contaminated humus. In general, however, $\mathrm{Zn}$ partitioning in till is similar to that observed in the Snow Lake area (Kaszycki and Hall, 1996) where it has been interpreted to represent the geochemical response to bedrock 
composition and glacial erosion and transport.

\subsubsection{Hg partitioning}

\section{$\underline{\text { Humus }}$}

Mercury concentrations in all phases of humus decrease with distance from the smelter (Fig. 5.6a). Unlike Zn, Hg concentrates primarily (>95 percent) in the non-labile component of the insoluble humus residue (Table 5.5; Fig. 5.6a) and, consequently $\mathrm{Hg}$ partitioning in humus is related either to Fe oxide, sulphide, and silicate minerals, such as those emitted from the smelter, and/or bound with "less soluble" organic material (Table 5.2). The probable influence of smelter-derived particulates on total $\mathrm{Hg}$ concentrations is particularly apparent at sites within $3 \mathrm{~km}$ of the smelter ( 1 and 11), where $\mathrm{Hg}$ concentrations exceed 10,000 ppb in non-labile phases. At all sites, however, the strong association of $\mathrm{Hg}$ with this non-labile component indicates that $\mathrm{Hg}$ is less mobile in the surface environment than $\mathrm{Zn}$.

The ratio between labile and non-labile components of the insoluble humus residue is low because of the overwhelming proportion of total $\mathrm{Hg}$ associated with non-labile phases. With the exception of sites $<3 \mathrm{~km}$ from the smelter (Fig. 5.6b), the relative proportion of $\mathrm{Hg}$ in the labile component tends to increase with distance from the smelter, following the relationship seen with $\mathrm{Zn}$. At those sites within $3 \mathrm{~km}$ (Sites 1 and 11), however, the proportion of $\mathrm{Hg}$ in the labile component of the insoluble residue is relatively high, with associated concentrations of 443 and $2590 \mathrm{ppb}$. This indicates that significant amounts of 

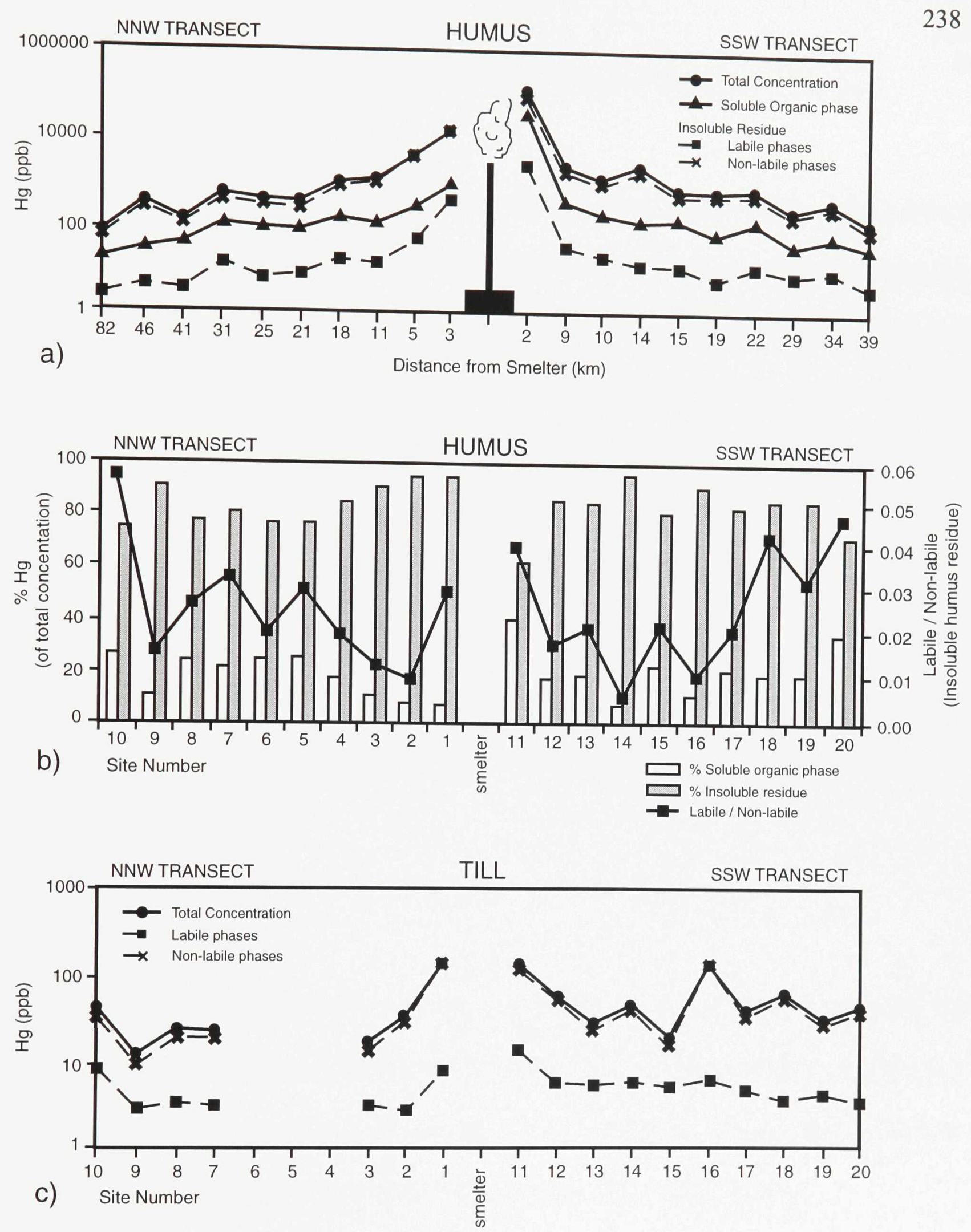

Figure 5.6 Partitioning of $\mathrm{Hg}$ in samples collected from transect sites: (a) total concentration in various phases of humus, (b) percent total $\mathrm{Hg}$ in soluble organic phase and insoluble humus residue and ratio between labile and nonlabile component of insoluble humus residue, (c) total concentration in various phases of till. 
Hg may be bio-available adjacent to the smelter, in areas of high contamination.

The proportion of $\mathrm{Hg}$ in the soluble organic phase of humus is low, varying from 6 to $40 \%$ (Table 5.5; Fig. 5.6b), and no correlation exists between percent LOI and percent $\mathrm{Hg}$ in the soluble organic phase (Fig. 5.7). In the NNW transect, the percent of total Hg in this phase increases before stabilizing at distances $>20 \mathrm{~km}$ from the smelter. This stabilisation may reflect a decrease in the influence of smelter-derived particulate matter associated with the non-labile component of the insoluble humus residue with distance from the smelter, however, no similar trend is evident in the SSW transect. High total $\mathrm{Hg}$ concentrations $(>1000 \mathrm{ppb})$ in the soluble organic phase at Site $11(<2 \mathrm{~km}$ from the smelter $)$ augment concentrations in the labile component of the insoluble humus residue, and further indicate the potential for significant amounts of $\mathrm{Hg}$ to become mobile in those highly contaminated areas adjacent to the stack.

$\underline{\text { Till }}$

Total $\mathrm{Hg}$ concentrations in till are low (Table 5.3; Fig. 5.6c). As with $\mathrm{Zn}, \mathrm{Hg}$ enrichment in labile phases is present at sites near the smelter (Sites 1 and 11) possibly as a result of downward leaching of heavy metals from anomalous concentrations in humus, and/or geological enrichment associated with mineralization near Flin Flon.

Over $95 \% \mathrm{Hg}$ is held in the non-labile component of till, particularly the crystalline Fe oxide (average 65\%) and the sulphide/ "less soluble" organic (average 21\%) phases. In 


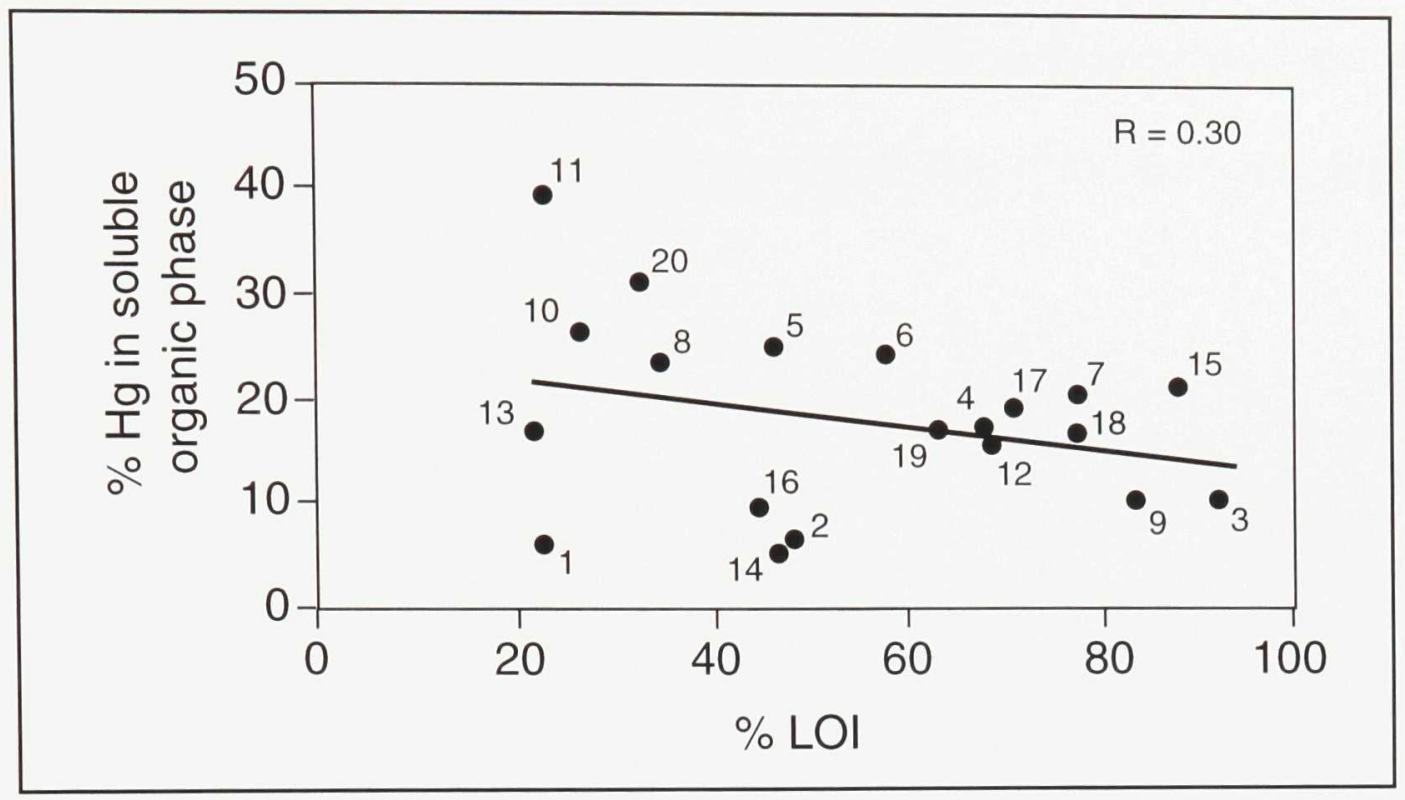

Figure 5.7 Relationship between \% $\mathrm{Hg}$ in soluble organic phase and total organic content (percent LOI). 
the latter phase, $\mathrm{Hg}$ is likely bound with either phyllosilicate minerals or organic material since sulphide minerals are absent in till due to weathering (Kaszycki et al., 1996). The proportion of $\mathrm{Hg}$ in the labile component varies from 5 to $27 \%$ and is unrelated to total $\mathrm{Hg}$ concentrations.

\subsubsection{Ni partitioning}

\section{$\underline{\text { Humus }}$}

No evidence of smelter-related contamination is indicated by Ni distribution in humus because of low total concentrations (Table 5.3) and the inherent analytical imprecision (Table 5.5). In general, Ni resides primarily in the non-labile component of the insoluble humus residue. At Site 10, total $\mathrm{Ni}$ values exceed $160 \mathrm{ppm}$ reflecting a similar enrichment in till (Table 5.3). Nickel in humus at this site is predominantly in the labile component of the insoluble humus residue, which suggests that enrichment may result from geological and biological factors associated with $\mathrm{Ni}$-rich mafic dykes in the area.

$\underline{\text { Till }}$

Nickel concentrations in till are higher than in humus (Table 5.3) and primarily reflect clastic dispersal from bedrock sources. An average of $83 \%$ of total $\mathrm{Ni}$ in transect and background samples is associated with the non-labile component, particularly the sulphide/"less soluble" organic phase. The percentage of Ni in the more labile component is generally higher in till samples overlying the Flin Flon greenstone belt and the Hanson Lake block (Site 10). This may be a function of the generally elevated trace element 
concentrations associated with these rocks (McMartin et al., 1996) and the resulting effects of weathering of sulphides and other Ni-rich minerals derived from greenstone belt lithologies.

\subsubsection{Partitioning in soil profiles}

Two soil profiles, varying in distance from the smelter and in geological context (Fig. 5.2), were examined in order to assess the geochemical effects of soil forming processes, and the extent of downward leaching of smelter related-elements (Fig. 5.8). Section A represents a shallow hole $(1 \mathrm{~m})$ dug to bedrock (Site 12), $8.75 \mathrm{~km} \mathrm{SSW}$ of the smelter stack. The area is underlain by mafic volcanic rocks of the Flin Flon greenstone belt which contain gold mineralization. Section B is a $5.3 \mathrm{~m}$ high section overlying Paleozoic dolostone, $42.5 \mathrm{~km}$ SE of Flin Flon, in an area where heavy metal concentrations in humus approach background values. Both sections represent a single till unit.

\section{$\underline{\text { Section A }}$}

Brunisolic soils are the commonest soils in the study area, developing mainly on glaciofluvial and glacial till deposits (Acton and Padbury, 1984). From the results of Fe analyses, the B-horizon can be seen to extend to approximately $45 \mathrm{~cm}$ depth (Fig. 5.8a).

Humus is enriched in $\mathrm{Hg}$ and $\mathrm{Zn}$ compared to till. In till, $\mathrm{Hg}$ and $\mathrm{Zn}$ concentrations are elevated near the top of the soil profile, decrease with depth in the B-horizon, and stabilize below this zone. Nickel concentrations, on the other hand, are depleted in humus 
Total Concentration
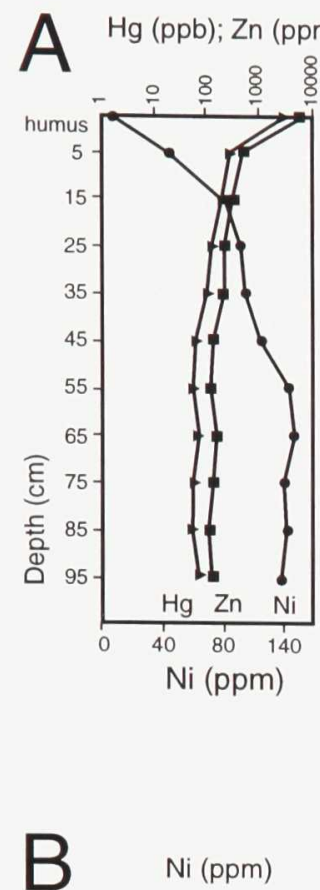

$\mathrm{Ni}(\mathrm{ppm})$

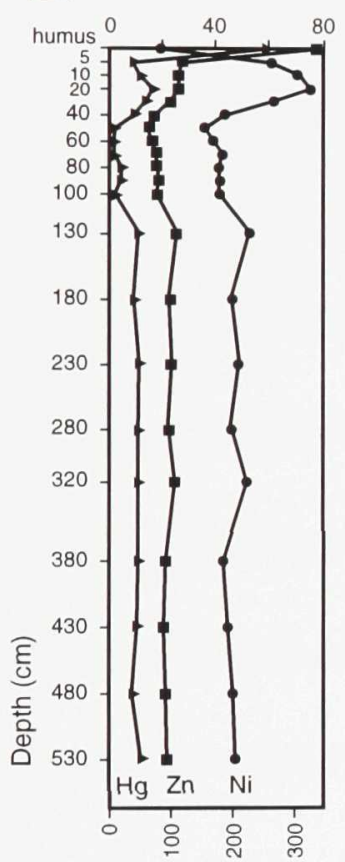

$\mathrm{Hg}$ (ppb); Zn (ppm)

\begin{abstract}
$\mathrm{Fe}(\%)$
\end{abstract}
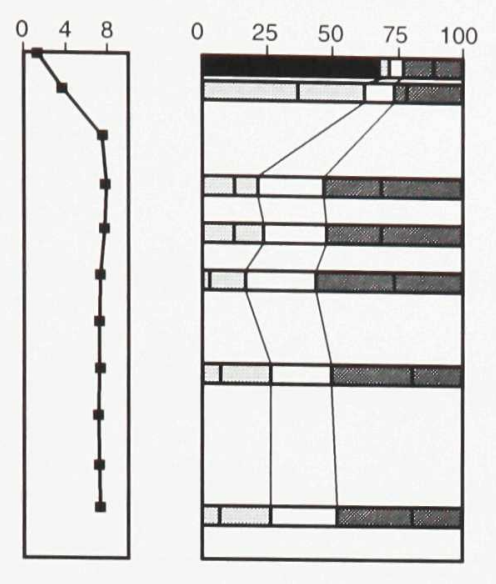

$\% \mathrm{CO}_{3} ; \% \mathrm{Fe}$

$\mathrm{Zn}(\%)$
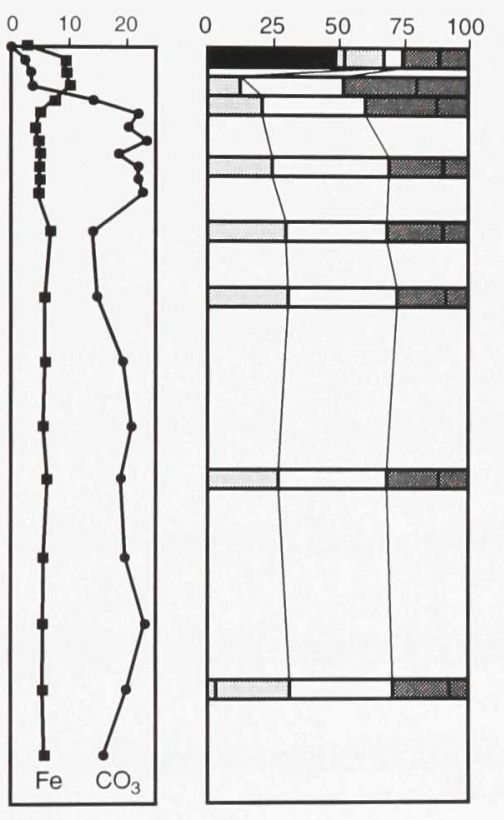

Soluble organic phase

$\square$ Crystalline Fe oxide phase
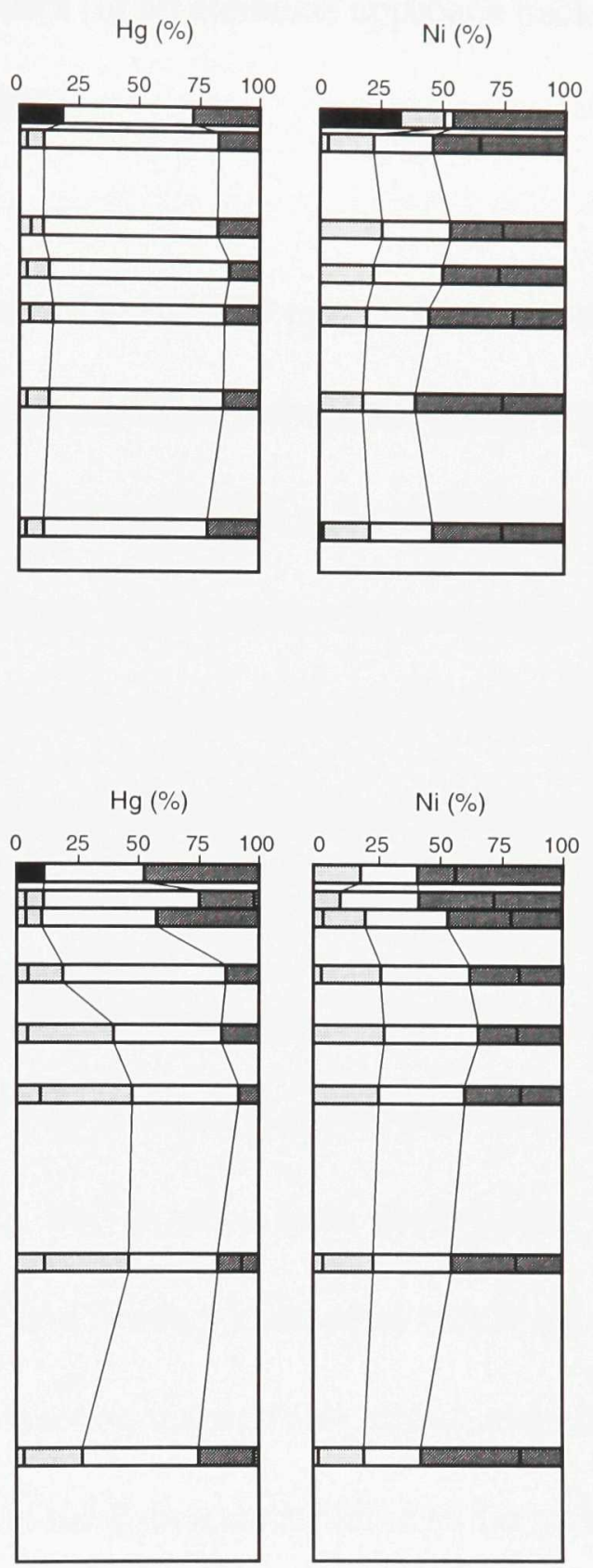

Sequential Leach

AEC and amorphous Fe/Mn oxide phases

Sulphides, "less" soluble organic and residual silicate phases

Figure 5.8 Trace element concentrations and partitioning of samples from vertical profiles: Section A (Shield-derived till) and Section B (Paleozoicderived till). 
and the B-horizon of till. Below $45 \mathrm{~cm}$ depth, values for all elements approach background levels for Shield-derived till (McMartin et al., 1999).

In Section A, over $70 \% \mathrm{Zn}(4624 \mathrm{ppm})$ and $16 \% \mathrm{Hg}(473 \mathrm{ppb})$ in humus is retained in an easily leached form and, consequently, may be mobilized within the soil profile. The high proportion of $\mathrm{Zn}$ associated with the labile component of till at $5 \mathrm{~cm}$ depth (Fig. 5.8a) suggests downward leaching occurs to that depth, at least. Below $25 \mathrm{~cm}$, however, the distribution of $\mathrm{Zn}$ among phases does not change with depth. Because Ni partitioning is similar to $\mathrm{Zn}$, and $\mathrm{Hg}$ partitioning shows no variation with depth, there is no evidence to support downward leaching below $25 \mathrm{~cm}$, based on the results of sequential extraction analyses. Based on total concentrations, however, the enrichment of $\mathrm{Zn}$ and $\mathrm{Hg}$, as opposed to the depletion of $\mathrm{Ni}$, in $\mathrm{B}$-horizon tills suggests that $\mathrm{Zn}$ and $\mathrm{Hg}$ contamination may occur within the section to a depth of $45 \mathrm{~cm}$, at least. Soil profiles from geologically similar terrane in the Snow Lake (Kaszycki et al., 1996) and Naosap Lake areas (McMartin et al., 1996; p. 52), located $>120$ and $>40 \mathrm{~km}$ from the smelter, respectively, are characterized by a depletion in most trace element concentrations in the B-horizon relative to the underlying material.

\section{$\underline{\text { Section B }}$}

In Section B, till is enriched in Paleozoic carbonate detritus and, consequently, the concentrations and distribution of trace elements differ from the previous section (Fig. 5.8). Because the section is located $>40 \mathrm{~km}$ from the smelter, $\mathrm{Zn}$ and $\mathrm{Hg}$ concentrations in humus 
are only slightly enriched compared to regional background (McMartin et al., 1996) and the underlying till. The upper $20 \mathrm{~cm}$ of the soil profile is leached of carbonate, and metal concentrations tend to be enhanced; from 30 to $100 \mathrm{~cm}$ carbonate is re-precipitated, and trace metal concentrations are relatively depleted; below $100 \mathrm{~cm}$, till is essentially unweathered (Fig. 5.8b). The B-horizon extends to approximately $40 \mathrm{~cm}$ depth.

No evidence for downward leaching of smelter-related elements is provided by sequential extraction analyses. Above $80 \mathrm{~cm}$ depth, less than $20 \%$ of the total metal concentration of all elements resides in the labile component of till (Fig. 5.8b), whereas below $80 \mathrm{~cm}$, the percent associated with these phases increases and partitioning among phases stabilizes, particularly for $\mathrm{Zn}$. At the base of the section, the percent $\mathrm{Hg}$ and $\mathrm{Ni}$ associated with the non-labile component of till increases as might be expected in the essentially unweathered C-horizon.

From the profiles, vertical variations in trace metal concentrations appear to result primarily from soil-forming processes, although evidence for downward leaching of smelterrelated elements from humus is indicated in the B-horizon of Section A. More extensive leaching may occur at those heavily contaminated sites (sites 1 and 11, see previous section) within $3 \mathrm{~km}$ from the smelter, based on the high proportions of $\mathrm{Zn}$ and $\mathrm{Hg}$ in the labile component of till (Figs. 5.4 and 5.6). Similar conclusions were reached by Hogan and Wotton (1984) and Freedman and Hutchinson (1980). 
5.6.4 SEM examination of particulate matter

Humus and till samples were examined qualitatively under the scanning electron microscope to determine the size, morphology and composition of particles enriched in heavy metals and to validate the results of metal speciation studies by sequential leaching. Samples from Sites 1, 7, 10-12, and 17 of the transects, Background Site 2 and Section B were examined.

\subsubsection{Humus}

In humus, smelter-related heavy metal particles were found at all sites. These particles occur as spheres, amalgamations of spheres, angular grains, and within organic material. Heavy metals may also occur as grain coatings. All particles examined were $>0.001 \mathrm{~mm}$ diameter. Results of SEM examination of samples from the NNW transect and Background Site 2 are summarized in Table 5.6.

\section{Spherical Particles}

The formation of spherical particles has been associated with natural geological processes, such as volcanism (Meeker and Hinkley, 1993), lightening strikes (Essene and Fisher, 1986) and cosmic dust (Murrell et al., 1980; Blanchard et al., 1980; Bi and Morton, 1995), as well as anthropogenic processes, such as smelting activities (Dunn et al., 1993). In general, spheres formed by natural processes differ in composition, texture and size from those observed in humus in the Flin Flon area. The composition of spherical particles examined in this study closely approximates smelter dust from the local plant (Chen and Pint, 


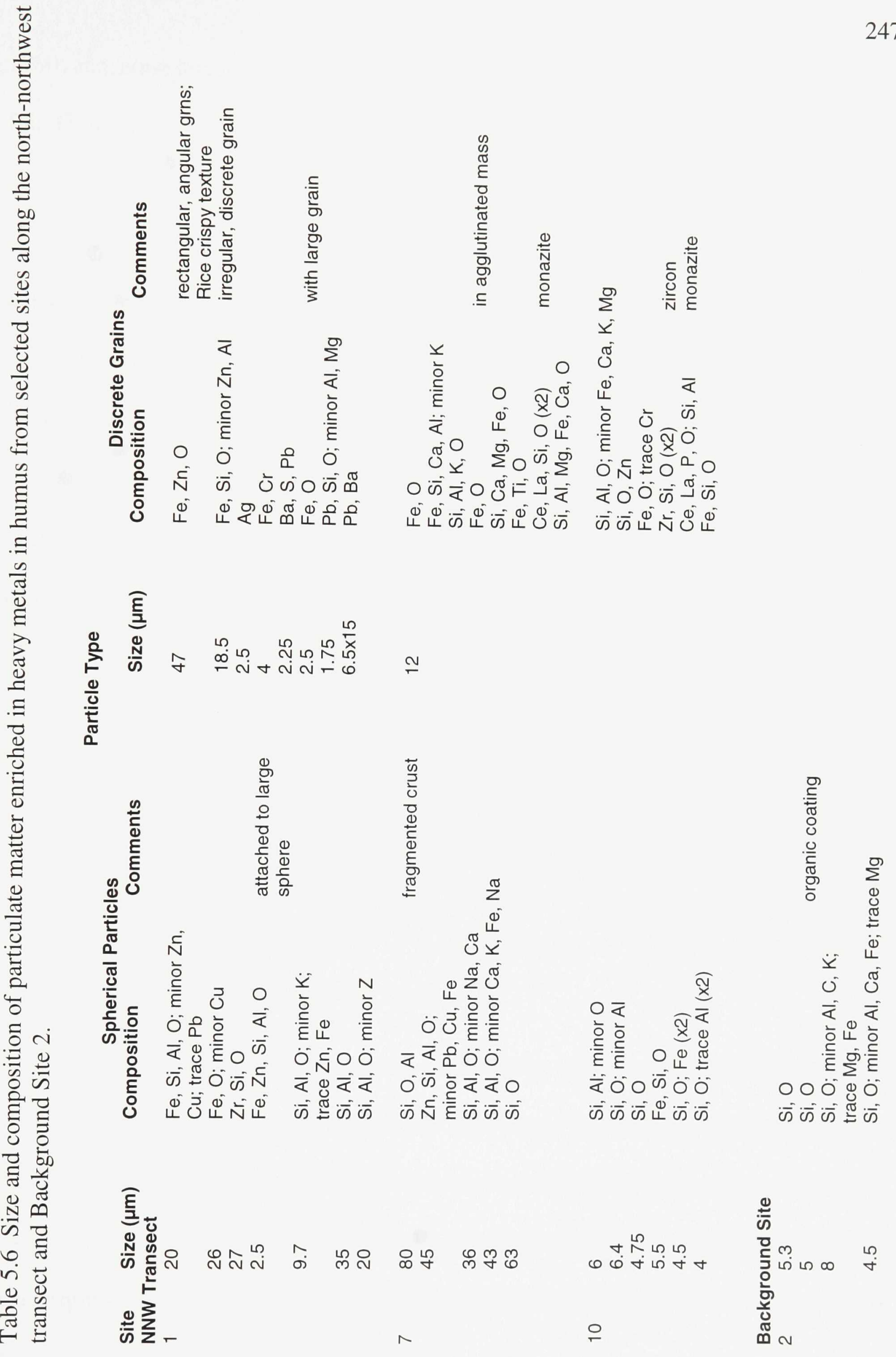


1980) and, consequently, they are interpreted as originating from the smelting process in the Flin Flon area.

Distinctive spherical particles were present in all humus samples examined. The particles tend to decrease in size and vary in composition with distance from the smelter (Table 5.6). Heavy metals, particularly $\mathrm{Fe}$ and $\mathrm{Zn}$, and to a lesser extent $\mathrm{Cu}$, are the major components of those spheres found closest to the smelter (Fig. 5.9a). At these sites, there is a broad inverse relation between sphere size and heavy metal content. Over $30 \mathrm{~km}$ from the stack, sphere composition is similar to glass $(\mathrm{Si}, \mathrm{O}, \mathrm{Al})$ and trace metals occur as minor or trace constituents. At sites $>40 \mathrm{~km}$ from the smelter, hollow and/or partially disintegrated (or malformed prior to deposition) (Figure 5.9b) spheres and glassy microspheres (averaging $0.005 \mathrm{~mm}$ diameter) are common. Microspheres are also present in humus $>160 \mathrm{~km}$ from the smelter, although they are rare and depleted in heavy metals. The general relationship between size, composition, and distance from the smelter indicates density sorting of spherical particles from the smelter stack.

\section{$\underline{\text { Angular Grains }}$}

Grains in humus include metal particulates, oxides and sulphides similar in composition to those observed in smelter dust (Chen and Pint, 1980). Although quantitative studies have not been made, the number of heavy metal grains in humus appears highest at sites within $30 \mathrm{~km}$ of the stack. At sites $<3 \mathrm{~km}$ from the stack, heavy metal grains dominate the proportion of all particles in humus attributed to smelting activities. Few angular grains 

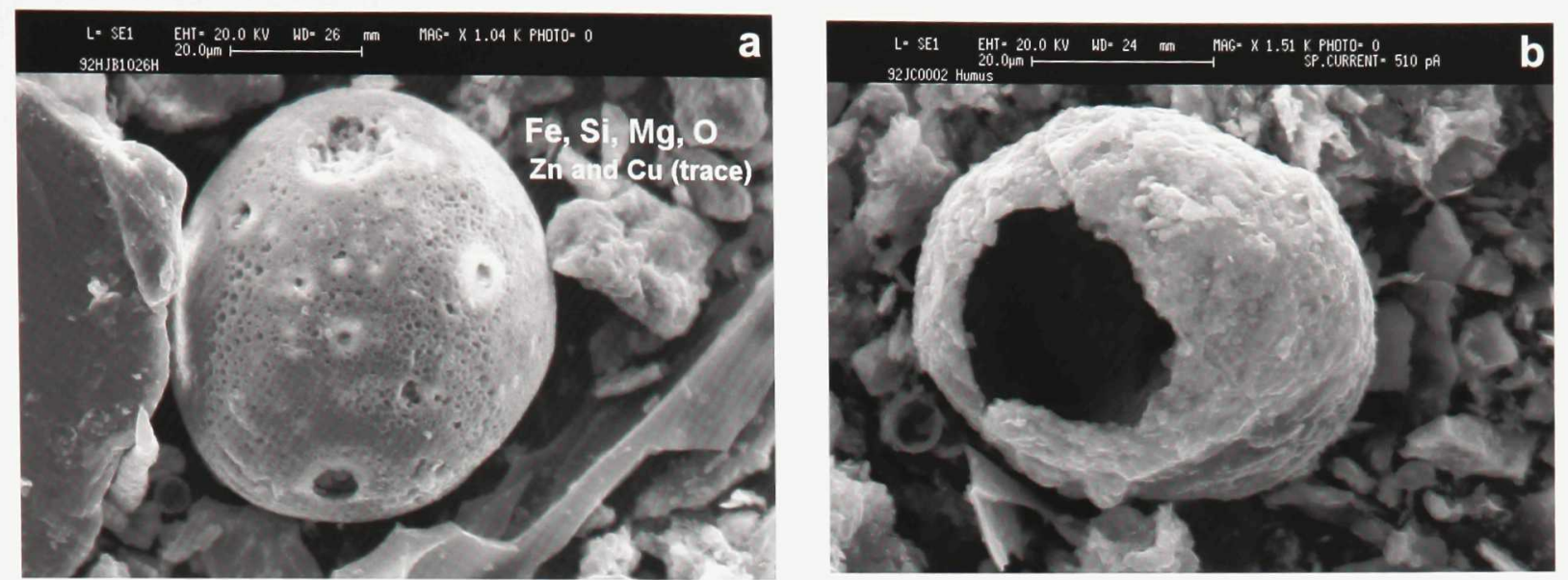

Figure 5.9 SEM secondary electron images showing morphology and composition of spherical particles in humus collected at varying distances from smelter: (a) heavy metal rich particle collected approximately $2 \mathrm{~km}$ SSW from smelter, and (b) hollow sphere composed of Si, Al, O, with minor $\mathrm{Mg}, \mathrm{Fe}, \mathrm{Na}$ and $\mathrm{Mn}$ collected $82 \mathrm{~km} \mathrm{NNW}$ of stack. 
with the composition and/or texture that could be linked to smelter emissions were found in humus at distances $>30 \mathrm{~km}$ from the stack.

The distribution, size, and composition of angular grains enriched in heavy metals is summarized in Table 5.6. Iron occurs as an oxide, either solely or with $\mathrm{Zn}$ or $\mathrm{Ti}$, as a sulphide with $\mathrm{Cu}$, and, less commonly, as a silicate with $\mathrm{Zn}$ or $\mathrm{Cu}$. At several sites $(1,11$ and 12), distinctive $\mathrm{Zn}$, Fe-oxide grains characterized by a regular geometric surface pattern (Figure 5.10) and Zn sulphide grains exhibiting a rough, spongy texture and, in one instance, a definite rim or coating, were observed. $\mathrm{Pb}$ occurs, at sites closest to the smelter, as a sulphide with $\mathrm{Ba}$ and/or $\mathrm{Fe}$ and $\mathrm{Zn}$, in regular, prismatic crystal forms. Mercury, in combination with Se and, in one case, Fe and S, was also observed at Site 11, closest to the smelter. The $\mathrm{Hg}$ rich grains are small $(<0.01 \mathrm{~mm})$, appear spongy, and may occur as coatings or crusts on larger grains, or as part of composite particles consisting of an amalgamation of grains differing in composition

No particles exhibiting the composition, surface texture, and morphology of these grains were found in till in any size fraction. Common rock-forming minerals, however, were recognized in both sample media.

\section{Organic Associations}

Trace elements associated with organic matter occur primarily as oxides ( $\mathrm{Fe}, \mathrm{O}$; Fe, $\mathrm{Zn}, \mathrm{O}$ with minor $\mathrm{Cu}$ ) or sulphides (Fe, $\mathrm{Cu}, \mathrm{S} ; \mathrm{Fe}, \mathrm{Zn} \mathrm{S} ; \mathrm{Fe}, \mathrm{S})$ and form particles ranging 


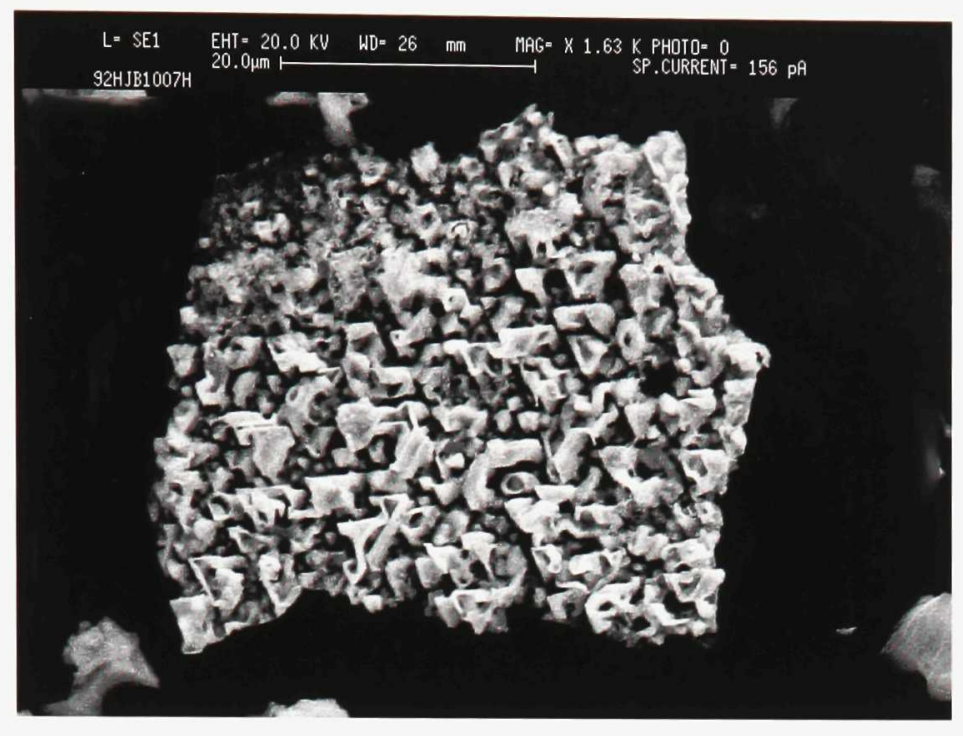

Figure 5.10 SEM secondary electron image of smelter-derived $\mathrm{Zn}$-rich particle observed in humus collected $3 \mathrm{~km} \mathrm{NNW}$ of stack.

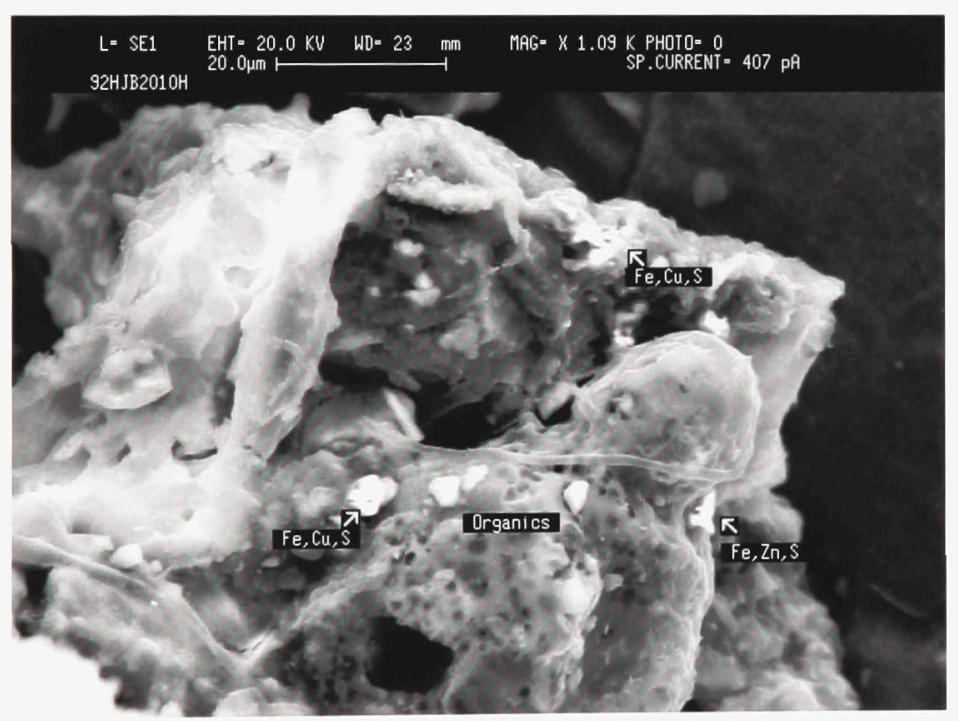

Figure 5.11 SEM mixed secondary and backscattered image showing metal rich particles and organic material in humus $17 \mathrm{~km} \mathrm{SSW}$ of stack. 
from $0.002-0.005 \mathrm{~mm}$ diameter (Fig. 5.11). Because oxides and sulphides of similar chemical composition have not been observed in till, these grains are interpreted as smelter related.

\subsubsection{Till}

No smelter-related particles were observed in the $<0.002 \mathrm{~mm}$ size fraction of till. Their absence may be a function of grain size because heavy metal particles observed in humus exceed $0.002 \mathrm{~mm}$ diameter.

One sphere was observed in the $<0.063 \mathrm{~mm}$ fraction of till collected at $0.7 \mathrm{~m}$ depth at Site 11, located within $2 \mathrm{~km}$ from the stack. The size and composition of the sphere is similar to those from humus at the same site, and indicates the possibility of sediment reworking, or, more likely, the incorportion of heavily contaminated surface material during sample collection.

\subsection{Discussion and conclusions}

The distribution of smelter-related heavy metals in humus observed in the vicinity of Flin Flon represents the historical record of contamination from mining and smelting activities in the region. Organic soils surrounding the smelter serve as a sink for heavy metals released to the environment as gases, aerosols or dusts from the smelter stack, ore stock piles and tailings, or during transport. The nature and extent of soil contamination is the net result of all primary depositional processes, including atmospheric fallout resulting 
from smelting activities, as well as secondary processes related to chemical and biochemical reactions associated with the atmospheric transport and deposition of smelter emissions, the decomposition of plant material, and the weathering of soils.

The nature and extent of smelter contamination in the region has varied through time depending on the size and density of emitted particles, ore composition, emission control technologies, and wind strength and direction. Once deposited or incorporated into the terrestrial environment, however, trace elements derived from mining and smelting activities in the area become part of the complex assemblage of soil materials, and are subject to the modification by biological, hydrological, and geological agents that is associated with soil forming processes. Emitted smelter particles, like primary rock-forming minerals, are chemically weathered, and their elemental components precipitate in secondary minerals, form complexes with inorganic and organic surfaces, or remain temporarily in the soil solution (Sposito, 1983).

In the vicinity of Flin Flon, the distribution of smelter-derived heavy metals in humus forms a "bull's eye" pattern centered on the smelter, with concentrations decreasing with distance from the smelter. Contaminant pathways in humus vary with the element and distance from the smelter, as indicated by the chemical speciation of $\mathrm{Zn}$ and $\mathrm{Hg}$. Zinc partitioning is controlled by several factors which include total organic content and the rate of deposition of smelter-derived particulates. Zinc is held primarily in an easily leached (labile) form, with an average of $54 \%$ in the soluble organic phase of humus at sites within 
$50 \mathrm{~km}$ of the smelter stack. The remaining $\mathrm{Zn}$ is held in the insoluble humus residue which consists of a labile and non-labile component. For $\mathrm{Zn}$, the relative proportion in these components indicates that non-labile phases associated with smelter particulate emissions dominate the insoluble humus residue within $30 \mathrm{~km}$ from the stack (NNW transect), and decrease in significance with increasing distance. This geochemical response is supported by SEM observations indicating density sorting of smelter-derived particulates from the smelter source. With distance from the smelter, the relative increase in $\mathrm{Zn}$ in the labile component of the insoluble humus residue reflects the effects of processes associated with chemical leaching and alteration. This suggests that near the stack the rate of clastic input of smelter-derived particulates exceeds the rate of chemical weathering. Partitioning in humus at sites $>30-40 \mathrm{~km}$ from the smelter primarily reflects bedrock control on till geochemistry such that the absolute contribution of smelter contamination on total concentrations of heavy metals becomes harder and harder to distinguish with distance.

In humus, $\mathrm{Hg}$ partitioning is largely controlled by the composition of the non-labile component of the insoluble humus residue. An average of $80 \%$ of total $\mathrm{Hg}$ is retained in this component and, consequently, $\mathrm{Hg}$ is less mobile than $\mathrm{Zn}$. The concentration, and, in part, the proportion of $\mathrm{Hg}$ in the non-labile phases decreases with distance from the smelter suggesting a decreased input of smelter-derived particulate matter with distance, as confirmed from SEM observations. Adjacent to the smelter $(<2 \mathrm{~km})$, however, elevated $\mathrm{Hg}$ concentrations (>1000 ppb) in the soluble organic phase, and the labile component of the 
insoluble humus residue, indicate the potential for significant amounts of $\mathrm{Hg}$ to be mobilized at highly contaminated sites.

On a regional scale, the geochemistry of till is a reflection of bedrock geology, modified by glacial erosion and transport (McMartin et al., 1999). At sites $<3 \mathrm{~km}$ from the smelter, however, elevated concentrations of $\mathrm{Zn}$ and $\mathrm{Hg}$ in labile phases of till may reflect downward leaching from humus in areas with high levels of contamination and poorly developed humus, in addition to the geochemical expression of the mineralization which established mining in the Flin Flon area. In a soil profile located $9 \mathrm{~km} \mathrm{SSW}$ of the smelter, vertical variations in total $\mathrm{Hg}$ and $\mathrm{Zn}$ concentrations provide evidence for the downward leaching of heavy metals from humus to the B-horizon, at least (approximately $45 \mathrm{~cm}$ depth).

The results of $\mathrm{Ni}$ partitioning in this study differ from those reported from areas adjacent to $\mathrm{Cu}-\mathrm{Ni}$ smelting facilities (Adamo et al., 1996; Niskavaara et al., 1996). In the Flin Flon area, Ni is not associated with smelter emissions and concentrations in humus are depleted compared to till. Ni exists primarily in a non-labile form in both sample media. In $\mathrm{Ni}$-contaminated areas, $\mathrm{Ni}$ is retained in labile phases of the $\mathrm{A}_{\mathrm{o}}$-horizon (Niskavaara et al., 1996), and the non-labile residual phases (60\%) of mineral soils ( $0-20 \mathrm{~cm}$ depth)(Adamo et al., 1996). 


\subsection{Possible criteria for distinguishing anthropogenic from natural sources of heavy metal enrichment}

Humus has been regarded as one of the best sampling media for mapping regional environmental contamination because of the strong geochemical contrast between anomalous and background concentrations resulting from its capacity to accumulate high levels of trace metals (Steinnes, 1984; Niskavaara et al., 1996). Determining the relative proportion of heavy metals in humus derived from anthropogenic sources, however, requires an appreciation for the 'natural' or geogenic component of the sample medium.

One method of estimating the geogenic component is based on the calculation of regional background values for humus (Table 5.1). These background values vary depending on the element and represent the median concentration for the data set after the elimination of most contaminated samples, ostensibly the natural background for humus in the Flin Flon area. The value is subjective because actual concentrations fluctuate over wide ranges depending on biological, chemical, and geological factors, and assumptions are made on the maximum extent of anthropogenic contamination (McMartin et al., 1999). Near the smelter, where concentrations of smelter-related elements are anomously high, regional background values serve as good approximations for natural concentrations, but, with increasing distance from the source, deviations from background values become more difficult to interpret. At those sites where total concentrations in humus approach calculated regional background values, both anthropogenic and natural components of the surficial material are subjected to weathering processes with the accompanying formation of secondary minerals and 
complexes having indistinguishable geochemical signatures. SEM observations have shown that smelter-related particles are present in humus at sites $>160 \mathrm{~km}$ from the source, and, undoubtedly, gaseous smelter emissions and particles $<0.001 \mathrm{~mm}$ diameter are subjected to transport for greater distances, well beyond the recognizable zone of smelter contamination defined in the regional study. Consequently, the relative proportion and maximum extent of anthropogenic contamination in humus will be difficult to estimate on the basis of humus geochemistry alone, especially at sites at or near regional background values.

Other proposed methods for estimating the geogenic component of humus are based on the geochemical composition of the underlying, essentially unweathered, till or C-horizon material (Steinnes and Njåstad, 1993; Niskavaara et al., 1996). In the Flin Flon area, the till (>45 $\mathrm{cm}$ depth) reflects the natural distribution of trace metals as it relates to bedrock geology, modified by glacial erosion, transport, and deposition. The geochemistry of humus, on the other hand, results from the complex interaction between geochemical, biogeochemical and atmospheric processes and, consequently, reflects both the geogenic and the anthropogenic component. Simple comparisons, such as ratios between trace metal concentrations in humus and till, highlight areas of anomalous anthropogenic enrichment, but become less sensitive indicators for distinguishing between the anthropogenic and geogenic input with distance from the smelter. The difficulty is related primarily to site specific variations in the composition of the two sample media, since site-to-site correlations between elemental concentrations in humus and till are poor to lacking in areas removed (>120 km) from the immediate effects of smelter contamination (Henderson, 1994; Kaszycki 
et al., 1996).

A realistic estimate of the anthropogenic component of humus is fundamental to mass balance studies focused on determining the proportion of total known smelter emissions that is represented by contaminated soil in the Flin Flon area. A meaningful calculation would also require knowledge of the distribution of heavy metals within the organic horizon, an assessment of the rate of weathering of smelter-derived particles and knowledge of the environmental pathways of elements held in easily leached forms, in order to determine the proportion of material removed or recycled in the soil horizons. 


\section{CHAPTER VI. SUMMARY AND CONCLUSIONS}

This thesis presents data and interpretations on the Quaternary geology and environmental geochemistry of the Flin Flon region. It is based on surficial geology and geochemical mapping studies undertaken by the author as part of the NATMAP Shield Margin Project at the Geological Survey of Canada in 1991-1995. The main conclusions drawn from each chapter are summarized below.

\subsection{Glacial geology}

Old westerly ice flow indicators and the occasional presence of calcareous tills preserved under Keewatin derived tills are the earliest record of a Labradorean ice advance through the Flin Flon region. Ice advances of eastern provenance have also been recognized in a large area of northern and central Manitoba and Saskatchewan, but conflicting ages have been attributed to these westerly events. Absolute chronology for the westerly flow is not possible at this time due to poor stratigraphy and lack of datable material in the study area. However, by correlation with the glacial stratigraphy of areas adjacent to the Flin Flon region, it is reasonable to assume this flow event is pre-Illinoian, or as young as Early Wisconsinan. Assuming an Early Wisconsinan age, the westerly flow may have originated from a dome centered in east-central Québec, recognized by recent ice flow indicator mapping in northern Ontario and adjacent Québec. In any case, this westerly advance must have originated from a centre of outflow located on the eastern side of Hudson Bay at least once prior to the last main glaciation, in order to account for the presence of distinctive 
greywacke erratics derived from the Omarolluk Fm of eastern Hudson Bay.

The second oldest ice flow event was southeast, from the Keewatin Sector of the Laurentide Ice Sheet. Its age is unknown and only the erosional record is recognized. A record of this southeasterly flow exists throughout north-central Manitoba, but again, timing of this flow event is unresolved. It could be either pre-Illinoian, depositing the Sundance till in northern Manitoba from a dispersal centre located in the District of MacKenzie (Northwest Territories), or (Middle?) Wisconsinan, if the previous westerly event is Early Wisconsinan in age. In this latter case, the southeasterly flow could have occurred during the last expansion of Keewatin ice in the region, prior to an eastward migration of an ice divide originally located in the District of MacKenzie.

Most of the surficial glacial deposits, streamlined features and erosional ice flow indicators relate to the last glaciation which spanned the (Late ?) Wisconsinan. Differences in the orientation of ice flow indicators and characteristics of surface till in the Flin Flon region indicate that at times during the last glaciation Keewatin ice covered the entire area, while at others, both Keewatin and Labradorean ice masses were active and confluent in the area. During the last glacial maximum (LGM), Keewatin ice flowed south-southwestward over resistant Precambrian lithologies from a dispersal centre located in Keewatin. Pervasive erosion by this flow essentially removed any older sediments and generated a thin till cover. This till is sandy textured and consists essentially of locally derived Precambrian debris. As this flow crossed onto the Paleozoic terrain, it deposited a thin blanket of silty sandy till, 
becoming progressively enriched with Paleozoic carbonate material. Locally derived Keewatin till is probably a basal till deposited at the base of active ice, and physical characteristics suggest the till was deposited by a subglacial process such as lodgement. This southerly flow affected the whole region and adjacent areas during the last main glaciation, as recorded by the pervasive nature of south-southwesterly ice flow indicators over the Shield, and by the southward decrease in Precambrian clast content over the Paleozoic cover, even in areas dominated by late Labradorean ice flows. Hence, during the LGM, the zone of confluence between the two ice masses was located east of the study area.

Early during deglaciation, a radial lobe of Labradorean ice flowed west over the region. The zone of confluence between Keewatin and Labrador Sector ice shifted westward, west of the provincial boundary. Labradorean ice reworked older sediments of Keewatin provenance and deposited a calcareous till whose composition reflects both a local and a distal provenance. As deglaciation proceeded, Labradorean ice retreated to The Pas Moraine, and Keewatin ice regained its influence west of the moraine, defining a major interlobate position. Adjustments of the ice masses positions occurred as Lake Agassiz invaded the area. Keewatin ice retreated north of Flin Flon then readvanced into the lake, leaving a till enriched with previously deposited sediments. Near the end of deglaciation, Labradorean ice readvanced into Lake Agassiz, fluting the top of The Pas Moraine. The final position of the zone of confluence between Keewatin and Labrador Sector ice is marked south of Reed Lake at the Reed Lake Interlobate Moraine. 


\subsection{Lake Agassiz history}

Six well-defined Lake Agassiz levels have been recognized within the study area through detailed mapping of abandoned strandlines and re-evaluation of published information along The Pas Moraine and within the Grass River Basin. Elevation measurements have also shown that the once-level shorelines of Lake Agassiz are now tilted upward to the northeast. The paleogeography of Lake Agassiz can therefore be defined by the location of the shorelines and their degree of differential uplift. The history of Lake Agassiz documented here relates to its last phases, characterized by continued ice retreat and the opening of successively lower outlets.

The Stonewall, The Pas and Gimli shorelines formed as Lake Agassiz discharged to the Atlantic Ocean through eastern outlets near Lake Nipigon. This probably occurred after $8.3 \mathrm{ka}{ }^{14} \mathrm{C} \mathrm{BP}$, based on eastern outlet chronology tied to the position and timing of moraines near Lake Nipigon. The recognition of Stonewall strandlines on the crest of The Pas Moraine in the Wanless area confirms that Lake Agassiz had fallen to the Stonewall level after Labradorean ice had retreated from this moraine. Based on the configuration of the lake, the distribution of associated glaciolacustrine sediments, and the number of reported varves within the Grass River Basin, the Labradorean ice margin was in equilibrium up-ice from the Hargrave Moraine during the Stonewall level, possibly at the Sipiwesk Moraine. Therefore, the ice front was already positioned outside the study area during the highest lake level documented here. During The Pas/Gimli level, at circa $8.2 \mathrm{ka} \mathrm{BP}$, glacial meltwaters continued to deposit fine-grained glaciolacustrine sediments which completely covered the 
morphologic surface expression of the Hargrave Moraine. As ice retreated north of the Lake Nipigon area in Ontario, Lake Agassiz discharge was perhaps diverted to outlets directly entering Lake Superior during the Grand Rapids/Drunken Point levels at approximately 8.1/8.0 ka BP. The high gradients measured on the Ponton strandlines suggest that Lake Agassiz may have continued to discharge into Lake Superior during the Ponton level, at about $7.9 \mathrm{ka}{ }^{14} \mathrm{C} \mathrm{BP}$, as the ice sheet prevented drainage to Hudson Bay. Lake Agassiz became confluent with the late Kinojévis level of Lake Ojibway when it fell below the Ponton level, after 7.9 ka BP.

Decreasing gradients on Lake Agassiz strandlines were observed in the Flin Flon region from higher $\left(0.34 \mathrm{~m} \mathrm{~km}^{-1}\right)$ to lower $\left(0.22 \mathrm{~m} \mathrm{~km}^{-1}\right)$ levels, reflecting the decreasing rate of glacio-isostatic rebound since the shorelines formed. These gradients compare with isostatic tilts recently obtained from higher Lake Agassiz paleo-shorelines south of the study area and from raised shorelines surrounding major lakes in Manitoba. However, they contrast significantly with previously reported shoreline gradients in the region. In addition, the tilting of these lower levels refutes the idea of little or no tilting during the Holocene as suggested by earlier workers. The northeastward direction of maximum tilt and the deformation of the water planes into shallow curves reflect the pattern of deformation centred in areas of maximum ice thickness during the last glacial maximum.

\subsection{Impact of smelter fallout on surrounding soils}

In the Flin Flon region, surface organic soils are enriched in trace and major elements 
primarily through atmospheric deposition and long-term upward translocation by plant roots and subsequent accumulation through plant litter decay. On a regional basis, the distribution of smelter elements ( $\mathrm{As}, \mathrm{Cd}, \mathrm{Cu}, \mathrm{Hg}, \mathrm{Pb}, \mathrm{Hg}$ ) in humus are controlled by distance from the smelter stack and prevailing wind. On a site-to-site basis, numerous factors affect humus geochemistry and contribute to differential retention and distribution of trace elements in the organic soils. These factors include composition of the underlying substrate, total organic content, state of decomposition of the humus layer, and stability of the elements in humus. In the underlying mineral soils, till geochemistry reflects the natural variation imposed by bedrock composition, and modified by glacial processes.

The recognizable smelter contamination zone forms a "bull's eye" pattern around the point source but extends slightly farther in the predominant southeasterly downwind direction. Dispersal distances average $85 \mathrm{~km}$, from 70 to $104 \mathrm{~km}$, with the distances of $\mathrm{Cd}<\mathrm{Pb}<\mathrm{Zn}<\mathrm{Hg}<\mathrm{Cu}<\mathrm{As}$. The slopes of the decay curves follow the order $\mathrm{Zn}>\mathrm{Cu}>\mathrm{Cd}>\mathrm{Pb}>\mathrm{As}>\mathrm{Hg}$, reflecting differences in the airborne behaviour of the smelter particulates. Density sorting of spherical particles from the smelter stack is indicated by relationships among size, composition and distance from the smelter. Maximum enrichment factors in humus are $\mathrm{Hg}>\mathrm{As}>\mathrm{Cu}>\mathrm{Zn}>\mathrm{Cd}>\mathrm{Pb}$. Associated values are 526x to 76x higher than background values. This is directly opposite to the relative proportion of smelter elements associated with the labile phases of humus (or 'bio-available'), suggesting that these elements can be preferentially mobilized and transported by groundwater. In contrast, the abundance of smelter elements in humus is $\mathrm{Zn}>\mathrm{Cu}=\mathrm{Pb}>\mathrm{As}>\mathrm{Cd}>\mathrm{Hg}$. This is similar to the 
order of background values determined statistically, and comparable to the order of historic smelter emission data, presumably a reflection of the average composition of the region's bedrock. However, metal ratios in humus are significantly different from those of the historical emissions. This is likely due to: 1) differential atmospheric fallout and removal mechanisms among the elements, 2) differential enrichment in the surface organic layer, and 3) migration of metals down the soil profile.

The relative proportion of element concentrations in humus related to smelter contamination vary within five concentric zones around the smelter as defined by total metal concentrations in surface organic soils. Zone A is the most contaminated and covers a small area around Flin Flon $(0-4 \mathrm{~km})$. Here, total smelter element concentrations average $212 \mathrm{x}$ the regional background. Over $99 \%$ of the enrichment is thought to be anthropogenic at $0 \mathrm{~km}$, and $97 \%$ at $4 \mathrm{~km}$. Sub-surface enrichment of smelter metals may occur at depth in this zone as indicated by the increased percentages of smelter-related elements in labile phases of the mineral soils (e.g., amorphous Fe/Mn oxides, adsorbed/exchangeable metals). In the least contaminated zone, Zone E, very low surface enrichment of smelter elements occurs on the forest floor (up to $2 \mathrm{x}$ the background). This zone extends between approximately $50 \mathrm{~km}$ from the stack and an average radius of $85 \mathrm{~km}$. At $50 \mathrm{~km}$ from the smelter, about $44 \%$ of the surface metal enrichment in humus results from smelter fallout. At 'background' distances $(>85 \mathrm{~km})$, the assumption is that smelter element concentrations represent the natural component, or $0 \%$ smelter-related. However, at these distances, the absolute contribution of smelter contamination becomes indistinguishable from the geochemical response related 
to the local bedrock composition.

\subsection{Conclusions}

The glacial geology of the Flin Flon region provides a significant contribution towards the understanding of the glacial history of Canada and to direct applications such as drift prospecting. Interpretations presented in this thesis represent the first comprehensive study of the glacial history of the Flin Flon region. The erosional and depositional records indicate multiple ice flow events, primarily related to the last cycle of glacial advance and retreat, at the confluence of two major Sectors of the Laurentide Ice Sheet. Nearly complete glacial erosion during these late glacial events prevented significant compositional masking of the underlying bedrock, a situation favourable to drift prospecting for base metals, gold or diamonds.

The succession of near-parallel strandlines recognized within the Flin Flon region records a series of six levels of Lake Agassiz that formed between approximately $8.3 \mathrm{ka}$ and $7.9 \mathrm{ka}{ }^{14} \mathrm{C}$ BP. Elevation measurements of newly-recognized strandlines and correlation of these strandlines with existing shoreline data indicate that the present-day gradient of the shorelines increases northeast. Corresponding paleo-water planes are tilted and deformed, indicating significant differential uplift during the Holocene in central Manitoba and Saskatchewan. This finding has major consequences regarding correlation of glacial lakes across the mid-continent, the post-glacial history of large lakes in the region, and for interpretations of earth rheology and its implications for ice sheet reconstruction. 
Elevated concentrations of $\mathrm{Zn}, \mathrm{Cu}, \mathrm{Pb}, \mathrm{As}, \mathrm{Cd}$ and $\mathrm{Hg}$ occur in the surface organic rich layer of forest soils in the vicinity of the Flin Flon smelter. At depth in mineral soils, smelter contamination is restricted to highly contaminated areas near the stack. The maximum radius of contamination varies among the major smelter elements, and no direct relationship exists among emission, deposition and sink concentrations, reflecting the complexity of factors influencing total metal concentrations in soils. Factors considered here include the natural geochemical signature of the underlying substrate, the airborne behavior of the smelter particulates, and natural soil-forming processes, such as biogeochemical enrichment in the surface organic layer and post-depositional mobilization of elements. With increasing distance from the smelter, these factors become significant and the relative proportion of anthropogenic contamination in the surface terrestrial environment is more difficult to estimate. 


\section{REFERENCES}

Acton, D.F. and Padbury, G.A., 1984. Soils of the Saskatchewan Precambrian Shield; in B.T. Schreiner (ed.), Quaternary Geology of the Precambrian Shield, Saskatchewan, Saskatchewan Energy and Mines, Report 221, p. 56-59.

Adamo, P., Dudka, S., Wilson, M.J., and McHardy, W.J., 1996. Chemical and mineralogical forms of $\mathrm{Cu}$ and $\mathrm{Ni}$ in contaminated soils from the Sudbury mining and smelting region; Canadian Environmental Pollution, 91: 11-19.

Agriculture Canada Expert Committee on Soil Survey, 1987. The Canadian System of Soil Classification; $2^{\text {nd }}$ edtion, Agriculture Canada Publication 1646, $164 \mathrm{p}$.

Andrews, J.T. and Dugdale, R.E., 1970. Age prediction of glacio-isostatic strandlines based on their gradients; Geological Society of America Bulletin, 81: 3769-3772.

Andrews, J.T., Shilts, W.W., and Miller, G.H., 1983. Multiple deglaciations of the Hudson Bay Lowlands, Canada, since deposition of the Missinaibi (last-interglacial?) Formation; Quaternary Research, 19:18-37.

Antevs, E., 1931. Late-glacial correlations and ice recession in Manitoba; Geological Survey of Canada, Memoir 168, 76 p.

Ashton, K.E., 1987. Preliminary geological map of the Kisseynew gneisses between the Sturgeon-Weir River and Kisseynew Lake, Saskatchewan, scale 1:50 000; Geological Survey of Canada, Open File 1410.

Ashton, K.E., 1989. The southern flank of the Kisseynew Gneiss Belt in Saskatchewan and its boundaries with the Flin Flon Volcanic Belt and the Hanson Lake Block; Geological Survey of Canada, Open File 2133, p. 17-20.

Ashton, K.E., Balzer, S.S., and Tran, H., 1995. Geology of the Galbraith-Attitti lakes area, Attitti Block (part of 63M/1 and /2); in Summary of Investigations 1995, Saskatchewan Geological Survey, Saskatchewan Energy and Mines, Miscellaneaous Report 95-4, p. 23-29.

Ashton, K.E., Heaman, L.M., Lewry, J.F., Hartlaub, and Shi, R., 1999. Age and origin of the Jan Lake Complex: a glimpse at the buried Archean craton of the Trans-Hudson Orogen; Canadian Journal of Earth Sciences, 36: 185-208.

Bailes, A.H. and Syme, E.C., 1989. Geology of the Flin Flon - White Lakes area; in Manitoba Energy and Mines, Minerals Division, Geological Report GR87-1. 
Bell, C.K., 1978. Geology, Wekusko Lake map-area, Manitoba; Geological Survey of Canada, Memoir 384, 84 p.

Berger, G.W. and Nielsen, E., 1990. Evidence for thermoluminescence dating for Middle Wisconsinan deglaciation in the Hudson Bay Lowland of Manitoba; Canadian Journal of Earth Sciences, 28: 240-249.

Bezys, R.K., 1991. Stratigraphic mapping (NTS 63F, 63K) and core hole program 1991; in Manitoba Energy and Mines, Minerals Division, Report of Activities 1991, p. 61-73.

Bezys, R.K., 1992. Stratigraphic mapping and core hole program 1992; in Manitoba Energy and Mines, Minerals Division, Report of Activities, 1992, p. 123-131.

Bi, D., and Morton, R.D., 1995. Magnetic spherules from recent fluvial sediments in Alberta, Canada: characteristics and possible origins; Canadian Journal of Earth Sciences, 32: 351-358.

Blanchard, M.B., Brownlee, D.E., Bunch, T.E., Hodge, P.W., and Kyte, F.T., 1980. Meteroid ablation spheres from deep-sea sediments; Earth Planetary Science Letters, 46: 178-190.

Bonham-Carter, G.F. and McMartin, I., 1997. Calculations on metals in humus around the base-metal smelter at Flin Flon, Manitoba, Canada; in V. Pawlowsky-Glahn (ed.), Proceedings, Third Annual Conference of the International Association for Mathematical Geology, International Center for Numerical Methods in Engineering, Barcelona, Spain, p. 262-267.

Boulton, G.S., 1976. The origin of glacially fluted surfaces - observations and theory; Journal of Glaciology, 17: 287-309.

Boulton, G.S., 1996. Theory of glacial erosion, transport, and deposition as a consequence of subglacial sediment deformation; Journal of Glaciology, 42: 43-62.

Boulton, G.S. and Clark, C.D., 1990. A highly mobile Laurentide Ice Sheet revealed by satellite images of glacial lineations; Nature, 346: 813-817.

Boulton, G.S. and Jones, A.S., 1979. Stability of temperate ice sheets resting on beds of deformable sediment; Journal of Geophysical Research, 92: 9059-9082.

Boulton, G.S., Dent, D.L., and Morriss, E.M., 1974. Subglacial shearing and crushing and the role of water pressures in tills from southeast Iceland; Geografiska annaler, 56A: 135-145. 
Broome, J., Viljoen, D., and the NATMAP Digital Working Group, 1995. Preliminary release of selected geoscience data for the NATMAP Shield Margin Project, Flin Flon area, Manitoba and Saskatchewan; Geological Survey of Canada, Open File 2743, CD-ROM Release.

Byers, A.R. and Dahlstrom, C.D.A., 1954. Geology and mineral deposits of the Amisk Wildnest Lakes area, Saskatchewan; Saskatchewan Department of Mineral Resources, Report No. 14, 177 p.

Campbell, J.E. and Henderson, P.J., 1997. Surficial geology of the Amisk Lake area (NTS 63L/9 and parts of 63K/12); Geological Survey of Canada, Map 1919A, scale 1:50 000 .

Campbell, J.E., McMartin, I., and Millard, M., 1997. Surficial geology, Sturgeon-Weir River area, Saskatchewan (NTS 63L/10 and L/15); Geological Survey of Canada, Open File 3485, scale 1:100 000 .

Campbell, J.E., Millard, M., and McMartin, I., 1998. Surficial geology, Attitti Lake area, Saskatchewan (NTS 63M/1 and M/2); Geological Survey of Canada, Open File 3565, scale 1:100 000 .

Chao, T.T., 1984. Use of partial dissolution techniques in geochemical exploration; Journal of Geochemical Exploration, 20: 101-135.

Chen, T.T. and Pint, P., 1980. Mercury in Canadian non-ferrous metals extraction circuits: Part 1 - Hudson Bay Mining and Smelting Company, Limited, Flin Flon, Manitoba; Minerals Research Program, Mineral Sciences Laboratories, Report 80-9, CANMET.

Chorley, R.J., Schumm, S.A, and Sugden, D.E., 1984. Geomorphology; Methuen and Co., London and New York, 605 p.

Christiansen, E.A., 1968. Pleistocene stratigraphy of the Saskatoon area, Saskatchewan, Canada; Canadian Journal of Earth Sciences, 5: 1167-1173.

Christiansen, E.A., 1979. The Wisconsinan deglaciation of southern Saskatchewan and adjacent areas; Canadian Journal of Earth Sciences, 16: 913-938.

Christiansen, E.A., 1992. Pleistocene stratigraphy of the Saskatoon area, Saskatchewan, Canada: an update; Canadian Journal of Earth Sciences, 29: 1767-1778.

Clark, P.U., Licciardi, J.M., MacAyeal, D.R., and Jenson, J.W., 1996. Numerical reconstruction of a soft-bedded Laurentide Ice Sheet during the last glacial maximum; Geology, 24 (8): 679-682. 
Clarke, M.D., 1989. Surficial geology, Cormorant Lake, Manitoba-Saskatchewan; Geological Survey of Canada, Map 1699A, scale 1:250 000.

Clayton, L. and Moran, S.R., 1982. Chronology of Late Wisconsinan glaciation in middle North America; Quaternary Science Review, 1: 55-82.

Clayton, L., Teller, J.T., and Attig, J.W., 1985. Surging of the southwestern part of the Laurentide Ice Sheet; Boreas, 14: 235-241.

CLIMAP Project Members, 1981. Seasonal reconstruction of the Earth's surface at the last glacial maximum; Geological Society of America, Map and Chart Series MC-36.

Craig, B.C., 1966. Preliminary reconnaissance of the surficial geology of The Pas area; in Report of Activities, Geological Survey of Canada, Paper 66-1, p. 139-140.

Coker, W.B. and DiLabio, R.N.W., 1989. Geochemical exploration in glaciated terrain, geochemical responses; in G.D. Garland (ed.), Proceedings of Exploration' 87, Ontario Geological Survey, Special Volume 3, p. 336-383.

Davies, B.E., 1983. Heavy metal contamination from base metal mining and smelting: implications for man and his environment; in I. Thornton (ed.), Applied Environmental Geochemistry, Academic Press Geology Series, London, p. 425-462.

Dreimanis, A., 1988. Tills: their genetic terminology and classification; in R.P. Goldthwait and C.L. Matsch (eds.), Genetic classification of glacigenic deposits, A.A. Balkema, Rotterdam, p. 17-83.

Dreimanis, A., 1990. Formation, deposition, and identification of subglacial and superglacial tills; in R. Kujansuu and M. Saarnisto (eds.), Glacial Indicator Tracing, A.A. Balkema, Rotterdam, p. 35-59.

Dreimanis, A. and Vagners, U.J., 1971. Bimodal distribution of rocks and mineral fragments in basal tills; in Goldthwait, R.P. (ed.), Till - A Symposium, Ohio State University Press, Columbus, Ohio, p. 237-250.

Dredge, L.A., 1983. Character and development of northern Lake Agassiz and its relation to Keewatin and Hudsonian ice regimes; in J.T. Teller and L. Clayton (eds), Glacial Lake Agassiz, Geological Association of Canada, Special Paper 26: 117-131.

Dredge, L.A. and Nielsen, E., 1985. Glacial and interglacial deposits in the Hudson Bay Lowlands: a summary of sites in Manitoba; Geological Survey of Canada, Paper 851A, p. 247-257. 
Dredge, L.A. and Nixon, F.M., 1992. Glacial and environmental geology of northeastern Manitoba; Geological Survey of Canada, Memoir 432, 80 p.

Dredge, L.A., Nixon, F.M., and Richardson, R.J., 1986. Quaternary geology and geomorphology of northwestern Manitoba; Geological Survey of Canada, Memoir $418,38 \mathrm{p}$.

Dredge, L.A. and Cowan, W.R., 1989. Quaternary geology of the southwestern Canadian shield; in R.J. Fulton (ed.), Chapter 3 of Quaternary Geology of Canada and Greenland, Geological Survey of Canada, Geology of Canada, no.1.

Dumontet, S., Dinel, H., and Lévesque, P.E.N., 1992. The distribution of pollutant heavy metals and their effect on soil respiration and acid phosphatase activity in mineral soils of the Rouyn-Noranda region, Québec; The Science of the Total Environment, 121: 231-245.

Dunn, J.G., Mackey, L.C., Smith, T.N., and Stevenson, I.R., 1993. Mineralogical study of products collected following pilot-scale smelting of some Western Australian nickel sulphide concentrates; Transactions of the Institute of Mining and Metallurgy, 102: C75-C82.

Dyke, A.S., 1996. Preliminary paleogeographic maps of glaciated North America; Geological Survey of Canada, Open File 3296.

Dyke, A.S., Dredge, L.A., and Vincent, J.-S., 1982. Configuration and dynamics of the Laurentide Ice Sheet during the Late Wisconsin Maximum; Géographie physique et Quaternaire, 36 ( 1-2): 5-14.

Dyke, A.S. and Prest, V.K., 1987a. Paleogeography of northern North America 18 000-5 000 years ago; Geological Survey of Canada, Map 1703A, scale 1:12 500000.

Dyke, A.S. and Prest, V.K., 1987b. Late Wisconsinan and Holocene history of the Laurentide Ice Sheet; Géographie physique et Quaternaire, 41: 237-264.

Elson, J.A., 1957. Lake Agassiz and the Mankato-Valders problem; Science, 126: 999-1002.

Elson, J.A., 1967. Geology of Glacial Lake Agssiz; in W.J. Mayer-Oakes (ed.), Life, Land and Water, Proceedings of the 1966 Conference on Environmental Studies, Glacial Lake Agassiz Region, University of Manitoba Press, Winnipeg, p. 36-95.

Environment Canada, 1993. Canadian Climate Normals, Volume 5, Flin Flon area, 19271990; Atmospheric Environment Service, Environment Canada, Downsview, Ontario. 
Essene, E.J. and Fisher, D.C., 1986. Lightning strike fusion: extreme reduction and metalsilicate liquid immiscibility; Science, 234: 189-193.

Eyles, N., Sladen, J.A., and Miall, A.D., 1982. A depositional model for stratigraphic complexes and facies superimposition in lodgement tills; Boreas, 11: 317-333.

Fisher, D.A., Reeh, N. and Langley, K., 1985. Objective reconstructions of the Late Wisconsinan Laurentide Ice Sheet and the significance of deformable beds; Géographie physique et Quaternaire, 49: 229-238.

Fisheries and Environment Canada, 1978. Hydrological Atlas of Canada, Permafrost distribution in Canada, Map 32.

Flint, R.F., 1943. Growth of the North American ice sheet during the Wisconsin age; Geological Society of America Bulletin, 54: 325-362.

Foscolos, A.E. and Barefoot, R.R., 1970. A rapid determination of total organic and inorganic carbon in shales and carbonates; Geological Survey of Canada, Paper 70$11,14 \mathrm{p}$.

Franzin, W.G., 1984. Aquatic contamination in the vicinity of the base metal smelter at Flin Flon, Manitoba, Canada - a case history; in J.O. Nriagu (ed.), Environmental Impacts of Smelters, John Wiley and Sons, New York, p. 523-550.

Franzin, W.G., McFarlane, G.A., and Lutz, A., 1979. Atmospheric fallout in the vicinity of a base metal smelter at Flin Flon, Manitoba, Canada; Environmental Science and Technology, 13(12): 1513-1522.

Freedman, B. and Hutchinson, T.C., 1980. Pollutant inputs from the atmosphere and accumulations in soils and vegetation near a nickel-copper smelter at Sudbury, Ontario, Canada; Canadian Journal of Botany, 58: 108-132.

Fulton, R.J., 1995. Surficial Materials of Canada; Geological Survey of Canada, Map 1880A, scale 1:5000 000 .

Geodetic Survey of Canada, 1980a. Vertical Control Data, Quad No. 54100; Geodetic Survey of Canada, Primary Vertical Control Section, 7 p.

Geodetic Survey of Canada, 1980b. Vertical Control Data, Quad No. 54101; Geodetic Survey of Canada, Primary Vertical Control Section, 17 p.

Geomatics Canada, 1995. NGDB Quad Output, Quad No. 53099; Geomatics Canada, Geodetic Survey Division, 31 p. 
Gobert, G. and Nielsen, E., 1991. Till geochemistry of the Snow Lake-File Lake area (NTS 63K/16, J/13); in Manitoba Energy and Mines, Report of Activities 1991, p. 47-48.

Godin, P.M., Feinberg, M.H., and Ducauze, C.J., 1985. Modelling of soil contamination by airborne lead and cadmium around several emission sources; Environmental Pollution (Series B), 10: 97-114.

Goodacre, A.K., Grieve, A.F. and Halpenny, J.F., 1987. Free Air Gravity Anomaly Map of Canada; Geological Survey of Canada, Geophysical Atlas, Map 2, scale $1: 10,000,000$.

Grice, R.H., 1970. Quaternary geology of the Grand Rapids area, Manitoba; Canadian Journal of Earth Sciences, 7: 853-857.

Haidl, F.M., 1992. Correlation of outcrop and subsurface data from Lower Paleozoic strata, Cumberland Lake-Namew Lake area, east central Saskatchewan; in Summary of Investigations 1992, Saskatchewan Geological Survey, Saskatchewan Energy and Mines, Miscellaneous Report 92-4, p. 213-219.

Hall, G.E.M., Vaive, J.E., Beer, R., and Hoashi, M., 1996. Phase selective leaches for use in exploration geochemistry; in G.F. Bonham-Carter, A.G. Galley and G.E.M. Hall (eds), Extech I: A Multidisciplinary Approach to Massive Sulphide Research in the Rusty Lake-Snow Lake Greenstone Belts, Manitoba, Geological Survey of Canada, Bulletin 426, p. 169-200.

Harrison, S.E. and Klaverkamp, J.F., 1990. Metal contamination in liver and muscle of northern pike (Esox lucius) and white sucker (Catostomus commersoni) and in sediments from lakes near the smelter at Flin Flon, Manitoba; Environmental Toxicology and Chemistry, 9: 941-956.

Henderson, P.J., 1994. Surficial geology and drift composition of the Bissett-English Brook area, Rice Lake Greenstone Belt, southeastern Manitoba; Geological Survey of Canada, Open File 2910.

Henderson, P.J., 1995a. Surficial geology and drift composition of the Annabel Lake-Amisk Lake area, Saskatchewan (NTS 63L/9, and part of 63K/12 and K/13); Geological Survey of Canada, Open File 3026.

Henderson, P.J., 1995b. Summary report on the surficial geology and drift composition in the Annabel Lake-Amisk Lake area, Saskatchewan (NTS 63L/9 and 16, and part of $63 \mathrm{~K} / 12$ and 13); in D.G. Richardson (ed.), Investigations completed by the Saskatchewan Geological Survey and the Geological Survey of Canada under the Geoscience Program of the Canada-Saskatchewan Partnership Agreement on Mineral 
Development (1990-1995), Geological Survey of Canada, Open File 3119, p.121130.

Henderson, P.J. and Campbell, J.E., 1992. Quaternary studies in the Annabel Lake-Amisk Lake area (NTS Areas 63L-9 and -16, and Part of 63K-12 and -13); in Summary of Investigations 1992, Saskatchewan Geological Survey, Saskatchewan Energy and Mines, Miscellaneous Report 92-4, p. 172-176.

Henderson, P.J. and Campbell, J.E., 1994. Surficial geology investigations related to drift prospecting in the Annabel Lake-Amisk Lake area, Saskatchewan (NTS 63L/9 and $\mathrm{L} / 16$ and part of $63 \mathrm{~K} / 12$ and K/13); in Summary of Investigations 1994, Saskatchewan Geological Survey, Saskatchewan Energy and Mines, Miscellaneous Report 94-4, p. 75-78.

Henderson, P.J. and McMartin, I., 1995. Mercury distribution in humus and surficial sediments in the vicinity of Flin Flon, Manitoba, Canada; Water, Air and Soil Pollution, 80: 1043-1046.

Henderson, P.J. and Roy, M., 1995. Distribution and character of gold in surface till in the Flin Flon greenstone belt, Saskatchewan; in Current Research 1995-E, Geological Survey of Canada, p. 175-186.

Henderson, P.J., McMartin, I., Hall, G.E.M., Percival, J.B., and Walker, D.A., 1998. The chemical and physical characteristics of heavy metals in humus and till in the vicinity of the base metal smelter at Flin Flon, Manitoba, Canada; Environmental Geology, 34: 39-58.

Hicock, S.R., Kristjansson, F.J., and Sharpe, D.R., 1989. Carbonate till as a soft bed for Pleistocene ice streams on the Canadian Shield north of Lake Superior; Canadian Journal of Earth Sciences, 26: 2249-2254.

Hogan, G.D. and Wotton, D.L., 1984. Pollutant distribution and effects in forests adjacent to smelters; Journal of Environmental Quality, 13(3): 377-382.

Hudson Bay Mining and Smelting, 1995. Hudson Bay Mining and Smelting Company Compliance Testing Report; Environmental Control Programs, Manitoba, Environmental Management Division, Winnipeg, Manitoba, 46 p.

Jackson, T.A., 1978. The biogeochemistry of heavy metals in polluted lakes and streams at Flin Flon, Canada, and a proposed method for limiting heavy-metal pollution of natural waters; Environmental Geolology, 2: 173-189.

Jackson, T.A., Klaverkamp, J.F., and Dutton, M.D., 1993. Heavy metal speciation and its 
biological consequences in a group of lakes polluted by a smelter, Flin Flon, Manitoba, Canada; Applied Geochemistry, 2: 285-289.

James, T.S. and Lambert, A., 1993. A comparison of VLBI data with the ICE-3G glacial rebound model; Geophysical Research Letters, 20 (9): 871-874.

Johnston, W.A., 1919. Reconnaissance soil survey of the area along the Hudson Bay railway; Geological Survey of Canada, Summary Report 1917, p. 25D-36D.

Johnston, W.A., 1946. Glacial Lake Agassiz, with special reference to the mode of deformation of the beaches; Geological Survey of Canada, Bulletin 7, $20 \mathrm{p}$.

Johnston, W.G.Q., 1978. Lake Agassiz's northernmost arm and other features of the Quaternary geology in the region around the southern part of Reindeer Lake, northern Saskatchewan; Musk-Ox, University of Saskatoon, 21, p. 39-50.

Kabata-Pendias, A. and Pendias, H., 1983. Trace elements in soils and plants; CRC Press, Inc., Boca Raton, Florida, USA, 325 p.

Kaszycki, C.A., 1987a. Glacial geomorphology of the southern Canadian Shield; in W.L. Graf (ed.), Chapter 5, Canadian Shield, Geomorphic systems of North America, Boulder, Colorado, Geological Society of America, Centennial Special Volume 2, p. $150-155$.

Kaszycki, C.A., 1987b. A model for glacial and proglacial sedimentation in the shield terrane of southern Ontario; Canadian Journal of Earth Sciences, 24: 2373-2391.

Kaszycki, C.A., 1989. Surficial geology and till composition, northwestern Manitoba; Geological Survey of Canada, Open File 2118.

Kaszycki, C.A. and Way Nee, V.J., 1990. Surficial geology, Kississing Lake, Manitoba; Geological Survey of Canada, Map 1757A, 1:250 000 scale.

Kaszycki, C.A., and Hall, G.E.M., 1996. Application of phase selective and sequential extraction methodologies in surficial geochemistry; in G.F. Bonham-Carter, A.G. Galley, and G.E.M. Hall (eds.), EXTECH I: A Multidisciplinary Approach to Massive Sulphide Research in the Rusty Lake-Snow Lake Greenstone Belts, Manitoba, Geological Survey of Canada, Bulletin 426, p. 155-168.

Kaszycki, C.A., Nielsen, E., and Gobert, G., 1996. Surficial geochemistry and response to volcanic-hosted massive sulphide mineralization in the Snow Lake region; in G.F. Bonham-Carter, A.G. Galley, and G.E.M. Hall (eds.), EXTECH I: A Multidisciplinary Approach to Massive Sulphide Research in the Rusty Lake-Snow 
Lake Greenstone Belts, Manitoba, Geological Survey of Canada, Bulletin 426, p. 139-154.

Klassen, R.A., 1997. Glacial history and ice flow dynamics applied to drift prospecting and geochemical exploration; in A.G. Gubins (ed.), Proceedings of Exploration 1997: Fourth Decennial International Conference on Mineral Exploration, p. 221-232.

Klassen, R.W., 1967. Surficial geology of the Waterhen-Grand Rapids area, Manitoba (63B, 63G); Geological Survey of Canada, Paper 66-36, 6 p.

Klassen, R.W., 1975. Quaternary Geology and geomorphology of Assiniboine and Qu'appelle valleys of Manitoba and Saskatchewan; Geological Survey of Canada, Bulletin 228, $61 \mathrm{p}$.

Klassen, R.W., 1979. Pleistocene geology and geomorphology of the Riding Mountain areas, Manitoba-Saskatchewan; Geological Survey of Canada, Memoir 396, 52 p.

Klassen, R.W., 1980a. Surficial geology, Wekusko Lake, Manitoba; Geological Survey of Canada, Map 4-1979, 1:250 000 scale.

Klassen, R.W., 1980b. Surficial geology, Nelson House, Manitoba; Geological Survey of Canada, Map 17-1978, 1:250 000 scale.

Klassen, R.W., 1983. Lake Agassiz and the late glacial history of northern Manitoba; in J.T. Teller and L. Clayton (eds.), Glacial Lake Agassiz, Geological Association of Canada, Special Paper 26, p. 97-115.

Klassen, R.W., 1986. Surficial geology, north-central Manitoba; Geological Survey of Canada, Memoir 419, $57 \mathrm{p}$.

Kleman, J., 1990. On the use of glacial striae for reconstruction of paleo-ice sheet flow patterns - with application to the Scandinavian ice sheet; Geografiska Annaler, 72A: 217-236.

Kor, P.S.G., Shaw, J. and Sharpe, D.R., 1991. Erosion of bedrock by subglacial meltwater, Georgian Bay, Ontario: a regional view; Canadian Journal of Earth Sciences, 28: 623-642.

Kreis, L.K. and Haidl, F.M., 1994. Computer-generated regional geological maps of southern Saskatchewan: Stonewall Formation; in Summary of Investigations 1994, Saskatchewan Geological Survey, Saskatchewan Energy and Mines, Miscellaneous Report 94-4, p. 175-180. 
Krumbein, W.C., 1937. Sediments and exponential curves; Journal of Geology, 45: 577-601.

Kupsch, W.O., 1952. Ordovician and Silurian stratigraphy of east-central Saskatchewan; Saskatchewan Department of Mineral Resources, Report 10, 62 p.

Kujansuu, R. and Saarnisto, M. (eds.), 1990. Glacial indicator tracing; A.A. Balkema, Rotterdam, 252 p.

Lambert, A., James, T.S. and Thorleifson, L.H., 1998. Combining geomorphological and geodetic data to determine postglacial tilting in Manitoba; Journal of Paleolimnology, 19: $365-376$.

Laville-Timsit, L. and Lecomte, P., 1992. Metal contamination in soils: distinguishing between natural and anthropogenic origins; in Proceedings, International Conference on Minerals, Metals and the Environment, February 4, 1992, Elsevier, Amsterdam, Manchester, p. 207-220.

Leclair, A.D., Lucas, S.B., Broome, H.J., Viljoen, D.W., and Weber, W., 1997. Regional mapping of Precambrian basement beneath Phanerozoic cover in southeastern TransHudson Orogen, Manitoba and Saskatchewan; Canadian Journal of Earth Sciences, 34: 618-634.

Lewis, C.F.M. and Anderson, T.W., 1989. Oscillations of levels and cold phases of the Laurentian Great Lakes caused by inflows from glacial Lakes Agassiz and BarlowOjibway; Journal of Paleolimnology, 2: 99-146.

Lewis, C.F.M. and Todd, B.J., 1996. Lithology and seismostratigraphy of long cores, and a reconstruction of Lake Winnipeg water level history; in B.J. Todd, C.F. M. Lewis, L.H. Thorleifson and E. Nielsen (eds.), Lake Winnipeg project: cruise report and scientific results, Geological Survey of Canada, Open File 3113, p. 161-192.

Lindsay, P.J. and Shilts, W.W., 1995. A standard laboratory procedure for separating claysized detritus from unconsolidated glacial sediments and their derivatives; in P.T. Borowsky, S.J. Sibbick, and J.M. Newell (eds.), Drift Exploration, Journal of Geochemical Exploration, 21: 239-247.

Lowell, T.V. and Teller, J.T., 1994. Radiocarbon vs. calendar ages of major late glacial hydrological events in North America; Quaternary Science Review, 13: 801-803.

Lucas, S.B., Syme, E.C., and Ashton, K.E., 1999. New perspectives on the Flin Flon Belt, Trans-Hudson Orogen, Manitoba and Saskatchewan: an introduction to the special issue on the NATMAP Shield Margin Project, Part 1; Canadian Journal of Earth Sciences, 36: 135-140. 
Lundqvist, J., 1990. Glacial morphology as an indicator of the direction of glacial transport; in R. Kujansuu and M. Saarnisto (eds.), Glacial indicator tracing, A.A. Balkema, p. 61-70.

Manitoba Department of Transportation, 1971. Final profile of Grand Rapids - Ponton Road ( 2 miles N. of William River to Hargrave River); Manitoba Department of Transportation, Highways Branch, District No. 10, The Pas, scale 1" = 400'.

Manitoba Energy and Mines, 1980. Mineral Map of Manitoba; Department of Energy and Mines, Mineral Resources Division, Map 80-1, scale 1:1 000000.

Matile, G.L.D. and Thorleifson, L.H., 1997. Till geochemical and indicator mineral reconnaissance of northeastern Manitoba; Manitoba Energy and Mines, Open File OF97-3, $174 \mathrm{p}$.

Mark, D.M., 1973. Analysis of axial orientation data, including till fabrics; Geological Society of America Bulletin, 84: 1369-1374.

McClenaghan, M.B., Thorleifson, L.H., and DiLabio, R.N.W., 1997. Till geochemical and indicator mineral methods in mineral exploration; in A.G. Gubins (ed.), Proceedings of Exploration 1997: Fourth Decennial International Conference on Mineral Exploration, p. 233-248.

McInnes, W., 1913. The basins of Nelson and Churchill rivers; Geological Survey of Canada, Memoir 30, $146 \mathrm{p}$.

McMartin, I., 1993a. Surficial Geology of the Talbot Lake area, Manitoba (NTS 63J3 to J6); Geological Survey of Canada, Open File 2744, scale 1:100 000.

McMartin, I., 1993b. Highlights of Quaternary geology investigations in the Cormorant Lake area (NTS 63K); in Manitoba Energy and Mines, Report of Activities 1993, p. 123 124.

McMartin, I., 1994a. Surficial geology of the Mitishto River area, Manitoba (NTS 63J11, J12, J14); Geological Survey of Canada, Open File 2835, scale 1:100 000.

McMartin, I., 1994b. Ice flow events in the Cormorant Lake - Wekusko Lake area, Northern Manitoba; in Current Research, Part C, Geological Survey of Canada, Paper 1994-C, p. $175-182$.

McMartin, I., 1994c. Surficial geology investigations in the Athapapuskow Lake area (Parts of NTS 63K/11 and K/12); in Manitoba Energy and Mines, Report of Activities 1994, p.65-67. 
McMartin, I., 1996. Lake Agassiz beaches and reconstruction of lower lake levels in the Shield Margin area, northwest of Lake Winnipeg; in B.J. Todd, C.F. M. Lewis, L.H. Thorleifson and E. Nielsen (eds.), Lake Winnipeg project: cruise report and scientific results, Geological Survey of Canada, Open File 3113, p. 403-420.

McMartin, I., 1997a. Surficial geology, Wuskatasko River area, Manitoba (NTS 63O/3,O/4); Geological Survey of Canada, Open File 3324, scale 1:100 000.

McMartin, I., 1997b. Surficial geology of the Rocky Lake area, Manitoba and Saskatchewan (NTS 63K/3,K/4,K/5,K/6); Geological Survey of Canada, Open File 3342, scale $1: 100000$.

McMartin, I., 1997c. Surficial geology of the Reed Lake area (NTS 63K/9, K/10); Geological Survey of Canada, Open File 3406, scale 1:100 000.

McMartin, I., 1998. Surficial geology, Athapapuskow Lake area, Manitoba (NTS $63 \mathrm{~K} / 11, \mathrm{~K} / 12$ ); Geological Survey of Canada, Open File 3526, scale 1:100 000.

McMartin, I., 1999a. Surficial geology, Hargrave Lake area; Geological Survey of Canada, Map 1954A, scale 1:100 000.

McMartin, I., 1999b. Additional radiocarbon dates from the Minago River channel area; in B.J. Todd, C.F.M. Lewis, L.H. Thorleifson and E. Nielsen (eds.), Report on the Lake Winnipeg Project Phase II, Geological Survey of Canada, Open File.

McMartin, I. and Boucher, R., 1995. Surficial geology of the North Moose Lake Area, Manitoba (NTS 63/K1,K2,K7,K8); Geological Survey of Canada, Open File 3060, scale 1:100 000 .

McMartin, I. and Campbell, J.E., 1994. Highlights of Quaternary geology investigations in the Sturgeon-Weir River area near Flin Flon; in Summary of Investigations 1994, Saskatchewan Geological Survey, Saskatchewan Energy and Mines, Miscellaneous Report 92-4, p. 137- 140.

McMartin, I. and Henderson, P.J., 1999. A relative ice-flow chronology for the Keewatin Sector of the Laurentide Ice Sheet, Northwest Territories (Kivalliq Region, Nunavut); Geological Survey of Canada, Paper 1999-C, p. 129-138.

McMartin, I. and Pringle, G., 1994. Regional kimberlite indicator mineral data and till geochemistry from the Wekusko Lake area, north-central Manitoba; Geological Survey of Canada, Open File Report 2844.

McMartin, I., Campbell, J.E., and Boucher, R., 1995. Surficial geology, Cumberland Lake 
area, Saskatchewan (NTS 63L/1,2,7,8); Geological Survey of Canada, Open File 3100, scale 1:100 000 .

McMartin, I., Henderson, P.J., Nielsen, E., and Campbell, J.E., 1996. Surficial geology, till and humus composition across the Shield Margin, north-central Manitoba and Saskatchewan: geospatial analysis of a glaciated environment; Geological Survey of Canada, Open File 3277.

McMartin, I., Henderson, P.J., and Nielsen, E., 1999. Impact of a base metal smelter on the geochemistry of soils of the Flin Flon region, Manitoba and Saskatchewan; Canadian Journal of Earth Sciences, 36: 141-160.

Meeker, G.P. and Hinkley, T.K., 1993. The structure and composition of microspheres from the Kilauea volcano, Hawaii; American Mineralogist, 78: 873-876.

Moran, S.R., 1969. Geology of the Hudson Bay area, Saskatchewan; Ph.D. Thesis, University of Illinois, Urbana, 175 p.

Mörner, N.-A., 1980. The Fennoscandian uplift: geological data and their geodynamical implication; in N.-A. Mörner (ed.), Earth rheology, isostasy and eustasy, Chichester, New York, p. 251-283.

Muller, E.H., 1983. Dewatering during lodgement of till; in E.B. Evenson, Ch. Schluchter, and J. Rabassa (eds.), Tills and related deposits, Proceedings, INQUA Syposium on the Genesis and Lithology of Quaternary deposits, 1981-1982, Balkema, Rotterdam, The Netherlands, p. 13-18.

Murrell, M.T., Davis, Jr. P.A., and Nishiizumi, K., 1980. Deep-sea spherules from Pacific clay: mass distribution and influx rate; Geochimica Cosmochimica Acta, 44: 2067 2074.

Nielsen, E., 1988. Surficial geology of the Swan River area; Manitoba Energy and Mines, Geological Report GR80-7, 51 p.

Nielsen, E., 1992. Surficial geology mapping and glacial dispersion studies as aids to geochemical exploration and mineral tracing in the Elbow Lake area (NTS 63K/15); in Manitoba Energy and Mines, Report of Activities 1992, p. 52-55.

Nielsen, E., 1993. Surficial geology and till geochemical sampling in the Naosap Lake area (63K/14); in Manitoba Energy and Mines, Report of Activities 1993, p. 47-49.

Nielsen, E., 1994. Highlights of surficial geology and till geochemical sampling in the Flin Flon area (NTS 63K/13); in Manitoba Energy and Mines, Report of Activities 1994, 
p. 81-82.

Nielsen, E. and Groom, H., 1987. Western Manitoba; in B.T. Schreiner, L.A. Dredge, E. Nielsen, R.W. Klassen, M.M. Fenton and J.R. Vickers (eds.), The Quaternary between Hudson Bay and the Rocky Mountains, Excursion Guide Book C-13, XII International Congress, International Union for Quaternary Research, National Research Council of Canada, Ottawa, p. 23-33.

Nielsen, E. and Groom, H., 1989. Trace element geochemistry and till provenance in The Pas - Flin Flon area, Manitoba; Manitoba Energy and Mines Open File Report OF89-3.

Nielsen, E., McNeil, D.H. and McKillop, W.B., 1987. Origin and paleoecology of post-Lake Agassiz raised beaches in Manitoba; Canadian Journal of Earth Sciences, 24: 14781485 .

Nielsen, E., Morgan, A.V., Morgan, A., Mott, R.J., Rutter, N.W., and Causse, C., 1986. Stratigraphy, paleoecology, and glacial history of the Gillam area, Manitoba; Canadian Journal of Earth Sciences, 23: 1641-1661.

Niskavaara, H., Reimann, C., and Chekushin, V., 1996. Distribution and pathways of heavy metals and sulphur in the vicinity of the copper-nickel smelters in Nikel and Zapoljarnij, Kola Peninsula, Russia, as revealed by different sample media; Applied Geochemistry, 11: 25-34.

Parent, M., Paradis, S.J., and Boivert, E., 1995. Ice flow patterns and glacial transport in the eastern Hudson Bay region: implications for Late Quaternary dynamics of the Laurentide Ice Sheet; Canadian Journal of Earth Sciences, 32: 2057-2070.

Pedersen, A., 1973. Ground water availability in The Pas area; Manitoba Resources Branch, Report \#9, Winnipeg.

Peltier, W.R., 1994. Ice age paleotopography; Science, 265: 195-201.

Peuraniemi, V., 1984. Weathering of sulphide minerals in till in some mineralized areas of Finland; in Prospecting in areas of glaciated terrain, Institution of Mining and Metallurgy, London, p. 127-135.

Phillips, S.F., Wotton, D.L., and McEachern, D.B., 1986. Snow chemistry in the Flin Flon area of Manitoba, 1981-1984; Water, Air and Soil Pollution, 30: 253-261.

Pip, E., 1991. Cadmium, copper, and lead in soils and garden produce near a metal smelter at Flin Flon, Manitoba; Bulletin of Environmental Contamination and Toxicology, 
46: 790-796.

Prest, V.K., Grant, D.R., and Rampton, V.N., 1968. Glacial Map of Canada; Geological Survey of Canada, Map 1253A, scale 1: 5000000.

Prest, V.K.,1983. Canada's heritage of glacial features; Geological Survey of Canada, Miscellaneous Report 28, 120 p.

Prest, V.K., 1990. Laurentide ice-flow patterns: a historial review, and implications of the dispersal of Belcher Island erratics; Géographie physique et Quaternaire, 44 (2): 113 136.

Rasmussen, P.E., 1996. Trace Metals in the Environment: a geological perspective; Geological Survey of Canada, Bulletin 429, 26 p.

Rayburn, J.A., 1997. Correlation of the Campbell strandlines along the northwestern margin of Glacial Lake Agassiz; M.Sc. Thesis, University of Manitoba, Winnipeg, 189 p.

Reilly, B.A., Thomas, D.J., Slimmon, W.L., Ashton, K.E., and Harper, C.T., 1995. Project Seagull: A multi-disciplinary approach to revisional geological bedrock mapping along the Precambrian Shield Margin in the Flin Flon-Amisk Lake area; in D.G. Richardson (ed.), Investigations completed by the Saskatchewan Geological Survey and the Geological Survey of Canada under the Geoscience Program of the CanadaSaskatchewan Partnership Agreement on Mineral Development (1990-1995), Geological Survey of Canada Open File 3119, p. 5-13.

Reimann, C., Caritat, P. de, Niskavaara, H., Finne, T.E., Kashulina, G., and Pavlov, V.A., 1998. Comparison of elemental contents in O- and C-horizon soils from the surroundings of Nikel, Kola Peninsula, using different grain size fractions and extractions; Geoderma, 84: 65-87.

Ringrose, S., 1975. A re-evaluation of late Lake Agassiz shoreline data from north central Manitoba; The Albertan Geographer, 11: 33-41.

Ripley, E.A., Redman, R.E., and Crowder, A.A., 1996. Environmental Effects of Mining; St. Lucie Press, Delray Beach, Florida.

Rose, A.W., Hawkes, H.E., and Webb. J.S., 1979. Geochemistry in mineral exploration ( $2^{\text {nd }}$ ed.); Academic Press Inc., London, 657 p.

Ross, W.C., 1986. Atomic absorption method for quantitative determination of carbonates in tills; Saskatchewan Research Council, Report R-842-4-B-86. 
Roy, M., 1998. Pleistocene stratigraphy of the Lower Nelson River area - implications for the evolution of the Hudson Bay Lowland of Manitoba; M.Sc. Thesis, Université du Québec à Montréal, 220 p.

Roy, M., Lamothe, M., and Nielsen, E., 1995. Stratigraphy of the Quaternary deposits of the Gillam area, northeastern Manitoba; in Manitoba Energy and Mines, Report of Activities 1995, p. 88-90.

Ruffman, A., Mollard, J.D., Nielsen, E., and McMartin, I., 1996. A possible post glacial fault in the Precambrian shield, north-central Manitoba; in Program with Abstracts, GACMAC Joint Annual Meeting, Winnipeg '96, May 27-29, A-81.

Salomon de Friedberg, A.M.S., 1993. Impurities at HBM\&S' Flin Flon copper smelter; CIM Bulletin, 86(971): 119-125.

Salonen, V.-P., 1988. Application of glacial dynamics, genetic differentiation of glaciogenic deposits and their landforms to indicator tracing in the search for ore deposits; in R.P. Goldthwait and C.L. Matsch (eds.), Genetic Classification of Glaciogenic Deposits, A.A. Balkema, Rotterdam, p. 183-190.

Samson, J., 1986. Contamination du sol par les métaux lourds venant d'un complexe métallurgique à Flin Flon (Manitoba); B.Sc. Thesis, Université Laval, Québec.

Schreiner, B.T., 1983. Lake Agassiz in Saskatchewan; in J.T. Teller and L. Clayton (eds), Glacial Lake Agassiz, Geological Association of Canada, Special Paper 26, p. 75-96.

Schreiner, B.T., 1984a. Quaternary geology of the Amisk Area (63-L,K) Saskatchewan; Saskatchewan Geological Survey, Open File Report 84-2, scale 1:250 000.

Schreiner, B.T., 1984b. Quaternary geology of the Precambrian Shield; Saskatchewan Energy and Mines, Saskatchewan Geological Survey, Report 221, 106 p.

Schreiner, B.T., 1990. Lithostratigraphic correlation of Saskatchewan tills: a mirror image of Cretaceous bedrock; Saskatchewan Research Council, Publication R-1210-3-E-90, $114 \mathrm{p}$.

Sharpe, D.R. and Shaw, J., 1989. Erosion of bedrock by subglacial meltwater, Cantley, Quebec; Geological Society of America Bulletin, 101: 1011-1020.

Shaw, J., 1988. Subglacial erosional marks, Wilton Creek, Ontario; Canadian Journal of Earth Sciences, 25: 1256-1267.

Sheldrick, B.H., 1984. Analytical methods manual, 1984; Research Branch, Agriculture 
Canada, LRRI Contribution no. 84-30.

Shewchuk, S.R., 1985. A study of atmospheric deposition onto the snowpack in Northern Saskatchewan; Annals of Glaciology, 7: 191-195.

Shilts, W.W.,1980. Flow patterns in the central North American ice sheet; Nature, 286 (5770): 213-218.

Shilts, W.W., 1982. Quaternary evolution of the Hudson/James Bay region; Naturaliste canadien, 109: 309-332.

Shilts, W.W., 1984. Till geochemistry in Finland and Canada; in A.J. Bjorklund (ed.), Geochemical Exploration 1983, Journal of Geochemical Exploration, 21: 95-117.

Shilts, W.W., 1993. Geological Survey of Canada's contributions to understanding the composition of glacial sediments; Canadian Journal of Earth Sciences, 30: 333-353.

Shilts, W.W., Cunningham, C.M. and Kaszycki, C.A., 1979. Keewatin Ice Sheet - Reevaluation of the traditional concept of the Laurentide Ice Sheet; Geology, 7: 537541.

Shilts, W.W. and Kettles, I.M., 1990. Geochemical-mineralogical profiles through fresh and weathered till; in R. Kujansuu and M. Saarnisto (eds.), Glacial indicator tracing, A.A. Balkema, Rotterdam, p. 187-216.

Singhroy, V. and Werstler, R., 1980. Sand and gravel resources and Quaternary geology of The Pas region; Manitoba Energy and Mines, Geological Report GR80-2, 60 p.

Sposito, G., 1983. The chemical forms of trace metals in soils; in I. Thornton (ed.), Applied Environmental Geochemistry, Academic Press, London, p. 123-170.

Steinnes, E., 1984. Heavy metal pollution of natural surface soils due to long-distance atmospheric transport; in B. Yaron, G. Dagan, and J. Goldschmid (eds.), Pollutants in porous media, Springer, Berlin, p. 115-122.

Steiness, E. and Njåstad, O., 1993. Reasons for enrichment of metals in the organic surface layer of natural soils; in R.J. Allan and J.O. Nriagu (eds.), Proceedings, 9th International Conference on heavy metals in the environment, CEP Consultants Ltd., Edinburgh, U.K., Vol. 2, p. 226-229.

Stern, R.A. and Lucas, S.B., 1995. Geochemistry and geochronology of volcanic and plutonic rocks, central Flin Flon Belt, Saskatchewan (NATMAP Shield Margin Project); in D.G. Richardson (ed.), Investigations completed by the Saskatchewan 
Geological Survey and the Geological Survey of Canada under the Geoscience Program of the Canada-Saskatchewan Partnership Agreement on mineral development (1990-1995), Geological Survey of Canada, Open File 3119, p. 99-110.

Stevenson, F.J., 1994. Humus Chemistry: Genesis, Composition, Reactions; John Wiley and Sons, Inc., Toronto.

Syme, E.C., Thomas, D.J., Bailes, A.H., Reilly, B.A., and Slimmon, W.L., 1993. Geology of the Flin Flon area, Manitoba and Saskatchewan (parts of NTS 63K and 63L); Geological Survey of Canada, Open File 2658, scale 1:50 000.

Syverson, K.M., 1995. The ability of ice-flow indicators to record complex, historic deglaciation events, Burroughs Glacier, Alaska; Boreas, 24: 232-244.

Tackman, G.E., 1997. Postglacial tilting and lake level change in Southern Manitoba; Ph.D. Thesis, University of Utah, Salt Lake City, 216 p.

Tackman, G.E., Currey, D.R., Bills, B.G., and Thomas, S.J., 1998. Paleoshoreline evidence for postglacial tilting in Southern Manitoba; Journal of Paleolimnology, 19: 343-363.

Tarnocai, C., 1970. Glacial history, surface deposits, soils and vegetation of Wekusko and portions of Cross Lake, Norway House and Grand Rapids map areas; in Proceedings of the Fourteenth Annual Manitoba Soil Science Meeting, p. 21-25.

Teller, J.T., 1985. Glacial Lake Agassiz and its influence on the Great Lakes; in P.F. Karrow (ed.), Quaternary Evolution of the Great Lakes, Geological Association of Canada, Special Paper 30, p. 1-16.

Teller, J.T. and Clayton, L., 1983. Glacial Lake Agassiz; Geological Association of Canada, Special Paper 26, University of Toronto Press, 451 p.

Teller, J.T. and Thorleifson, L.H., 1983. The Lake Agassiz - Lake Superior connection; in J.T. Teller and L. Clayton (eds), Glacial Lake Agassiz, Geological Association of Canada, Special Paper 26, p. 261-290.

Teller, J.T., Dredge, L.A., Hobbs, C.H.and Schreiner, B.T., 1983. Maximum extent and major features of Lake Agassiz; in J.T. Teller and L. Clayton (eds), Glacial Lake Agassiz, Geological Association of Canada, Special Paper 26, p. 43-45.

Thorleifson, L.H., 1989. Quaternary stratigraphy of the central Hudson Bay Lowland, northern Ontario, Canada; Ph.D. Thesis, University of Colorado, Boulder, 363 p.

Thorleifson, L.H., 1996. Review of Lake Agassiz history; in J.T. Teller, L.H. Thorleifson, 
G. Matile and W.C. Brisbin (eds.), Sedimentology, geomorphology and history of the central Lake Agasiz basin, Appendix, Field Trip Guide Book B2, Geological Association of Canada, Joint Annual Meeting, Winnipeg '96, p. 55-84.

Thorleifson, L.H. and Kristjansson, F.J., 1993. Quaternary geology and drift prospecting, Beardmore-Geralton area, Ontario; Geological Survey of Canada, Memoir 435, 146 p.

Thorleifson, L.H., Wyatt, P.H., and Warman, T.A., 1993. Quaternary stratigraphy of the Severn and Winisk drainage basins, Northern Ontario; Geological Survey of Canada, Bulletin 442, $59 \mathrm{p}$.

Thorleifson, L.H. and Garrett, R.G., in press. Lithology, mineralogy, and geochemistry of glacial sediments overlying kimberlite at Smeaton, Saskatchewan, Canada; Geological Survey of Canada, Bulletin.

Todd, B.J., Lewis, C.F.M., Nielsen, E., Thorleifson, L.H., Bezys, R.K., and Weber,W., 1998. Lake Winnipeg: geological setting and sediment seismostratigraphy; Journal of Paleolimnology, 19: 215-244.

Tushingham, A.M. and Peltier, W.R., 1992. Validation of the ICE-3G model of WürmWisconsin deglaciation using a global data base of relative sea level histories; Journal of Geophysical Research, 97 (B3): 3285-3304.

Tushingham, A.M. and Peltier, W.R., 1991. Ice-3G: A new global model of Late Pleistocene deglaciation based upon geophysical predictions of post-glacial relative sea level change; Journal of Geophysical Research, 96 (B3): 4497-4523.

Tyrrell, J.B., 1891. Pleistocene of the Winnipeg Basin; American Geology, 8: 19-28.

Tyrrell, J.B., 1892. Report on North-Western Manitoba with portions of the adjacent Districts of Assiniboia and Saskatchewan; Geological Survey of Canada, Annual Report, Pt. E.

Tyrrell, J.B., 1902. Report on explorations in the northeastern portion of the District of Saskatchewan and adjacent parts of the District of Keewatin; Geological Survey of Canada, Annual Report, v. XIII, Pt. F, 218 p.

Tyrrell, J.B., 1914. The Patrician glacier south of Husdon Bay; XII International Geological Congress (1913), Ottawa, p. 523-534.

Tyrrell, J.B., 1917. Discussion; in W.A. Johnston (author), Records of Lake Agassiz, in southeastern Manitoba, and adjacent parts of Ontario, Canada, Geological Society of 
America Bulletin, 28: 145-148.

Upham, W., 1890. Report of exploration of the glacial Lake Agassiz in Manitoba; Geological Survey of Canada, Annual Report 1988-89, Part E, 156 p.

Upham, W., 1895. The Glacial Lake Agassiz; United States Geological Survey, Monograph 25,658 p.

Van Loon, J.C. and Beamish, R.J., 1977. Heavy-metal contamination by atmospheric fallout of several Flin Flon area lakes and the relation to fish populations; Journal of the Fisheries Resources Board of Canada, 34: 899-906.

Varskog, P., Flaten, T.P., and Steiness, E., 1993. Relations between elemental concentrations and soil organic matter content in Norwegian forest soils; in R.J. Allan and J.O. Nriagu (eds.), Proceedings, 9th International Conference on heavy metals in the environment, CEP Consultants Ltd., Edinburgh, U.K., 2: 167-169.

Veillette, J.J., 1986. Former southwesterly ice flows in the Abitibi-Timiskaming region: implications for the configuration of the late Wisconsinan ice sheet; Canadian Journal of Earth Sciences, 23: 1724-1741.

Veillette, J.J., 1995. New evidence for northwestward glacial ice flow, James Bay region, Quebec; Geological Survey of Canada, Paper 1995-1C, p. 249-258.

Veillette, J.J., Dyke, A.S., and Roy, M., 1999. Ice-flow evolution of the Labrador Sector of the Laurentide Ice Sheet: a review, with new evidence from northern Quebec; Quaternary Science Reviews, 18: 993-1019.

Viljoen, D., McMartin I., Leclair A.D., Bezys R.K., McGregor C.K. and Haidl F., 1996. Digital elevation modelling of Precambrian, Paleozoic and Quaternary surfaces south of the shield margin, Manitoba and Saskatchewan; in Program with Abstracts, GACMAC Joint Annual Meeting, Winnipeg ‘96, A-99.

Walcott, R.I., 1972. Late Quaternary vertical movements in Eastern North America: quantitative evidence of glacio-isostatic rebound; Review of Geophysics and Space Physics, 10 (4): 849-884.

Wyatt, P.H., 1989. The stratigraphy and amino acid chronology of Quaternary sediments in central Hudson Bay Lowland; M.Sc. Thesis, University of Colorado, 119 p.

Zoltai, S.C., 1967. Eastern outlets of Lake Agassiz; in W.J. Mayer-Oakes (ed.), Life, Land and Water, Proceedings of the 1966 Conference on Environmental Studies, Glacial Lake Agassiz Region, University of Manitoba Press, Winnipeg, p. 107-120. 
Zoltai, S.C., 1988. Distribution of base metals in peat near a smelter at Flin Flon, Manitoba; Water, Air and Soil Pollution, 37: 217-228.

Zwanzig, H.V. and Schledewitz, D.C.P., 1992. Geology of the Kississing-Batty lakes area: Interim Report; Manitoba Energy and Mines, Open File Report OF92-2, 87 p. 